\title{
SURFICIAL GEOLOGY AND GEOHAZARDS IN THE ALASKA HIGHWAY CORRIDOR, ALASKA
}

Richard D. Reger, Trent D. Hubbard, and Rich D. Koehler

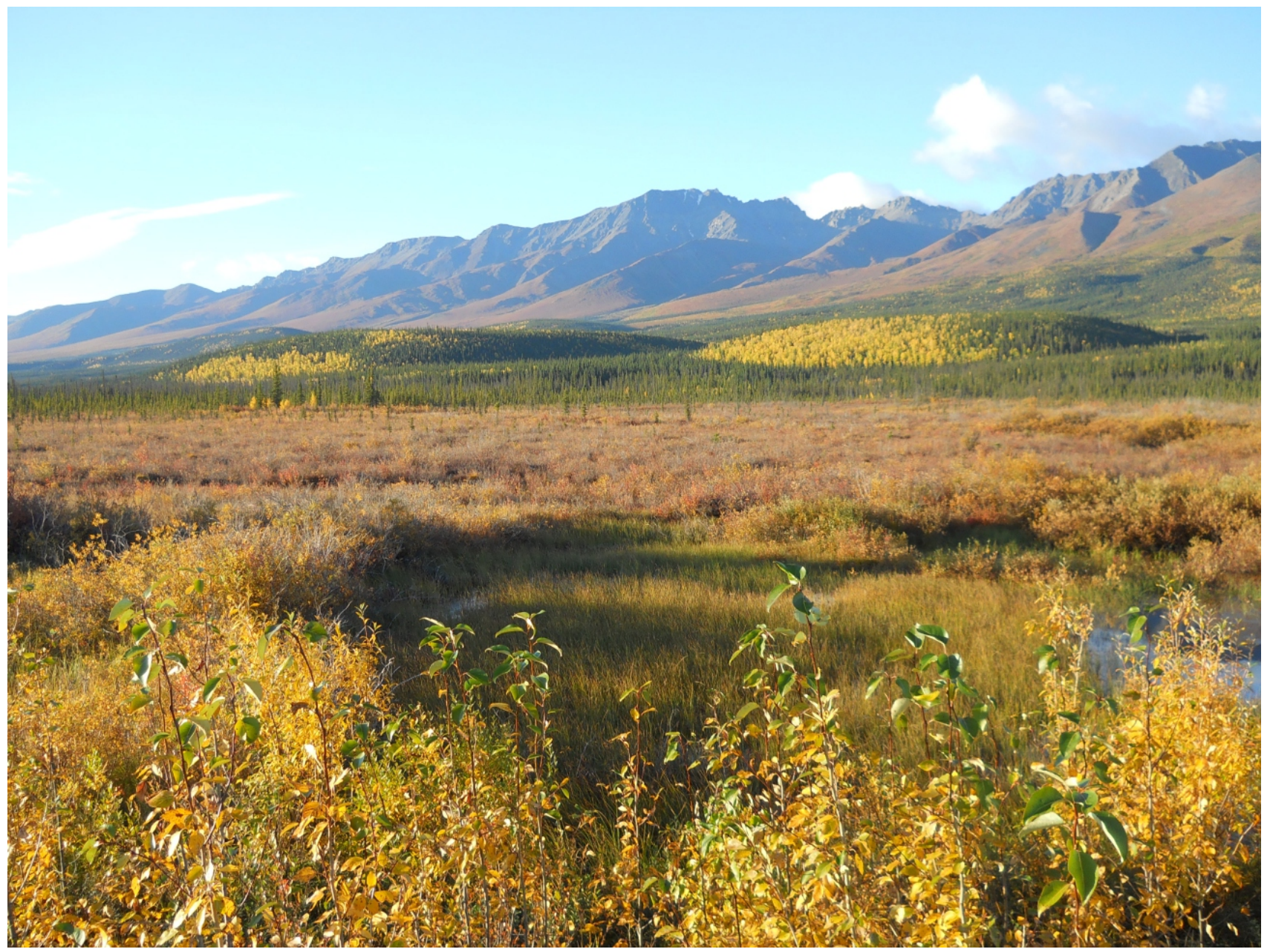

View southward of tree-covered, discontinuous, winding, anticline ridge formed by thrust faulting along the tectonically active, northern front of the eastern Alaska Range, Tanacross B-5 Quadrangle. Photograph taken 9/4/2012.

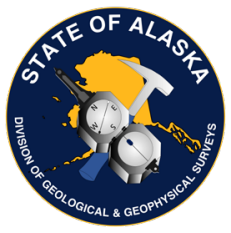

Published by

STATE OF ALASKA

DEPARTMENT OF NATURAL RESOURCES

DIVISION OF GEOLOGICAL \& GEOPHYSICAL SURVEYS 

Professional Report 124

\section{SURFICIAL GEOLOGY AND GEOHAZARDS IN THE ALASKA HIGHWAY CORRIDOR, ALASKA}

Richard D. Reger, Trent D. Hubbard, and Rich D. Koehler 


\section{STATE OF ALASKA}

Mike Dunleavy, Governor

\section{DEPARTMENT OF NATURAL RESOURCES}

Corri A. Feige, Commissioner

\section{DIVISION OF GEOLOGICAL \& GEOPHYSICAL SURVEYS}

Steve Masterman, State Geologist and Director

Publications produced by the Division of Geological \&

Geophysical Surveys (DGGS) are available to download from the DGGS website (dggs.alaska.gov). Publications on hardcopy or digital media can be examined or purchased in the Fairbanks office:

Alaska Division of Geological \& Geophysical Surveys 3354 College Rd., Fairbanks, Alaska 99709-3707

Phone: (907) 451-5010 Fax (907) 451-5050

dggspubs@alaska.gov|dggs.alaska.gov

DGGS publications are also available at:

Alaska State Library,

Historical Collections \& Talking Book Center

395 Whittier Street

Juneau, Alaska 99811

Alaska Resource Library and Information Services (ARLIS)

3150 C Street, Suite 100

Anchorage, Alaska 99503

\section{Suggested citation:}

Reger, R.D., Hubbard, T.D., and Koehler, R.D., 2021, Surficial geology and geohazards in the Alaska Highway corridor, Alaska: Alaska Division of Geological \& Geophysical Surveys Professional Report 124, 149 p., 18 sheets, scale 1:63,360. doi.org/10.14509/29701
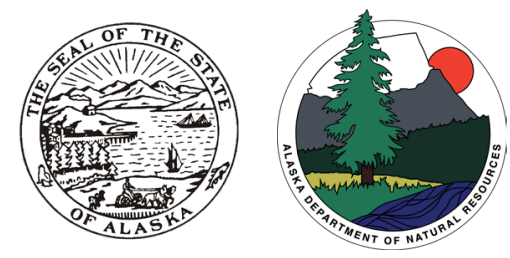


\section{Contents}

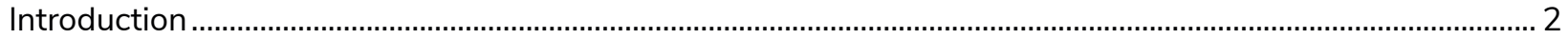

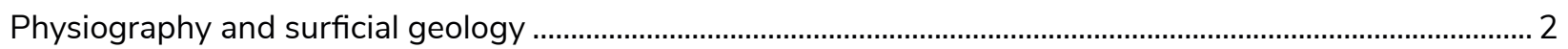

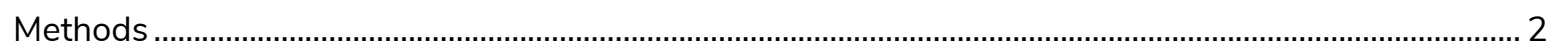

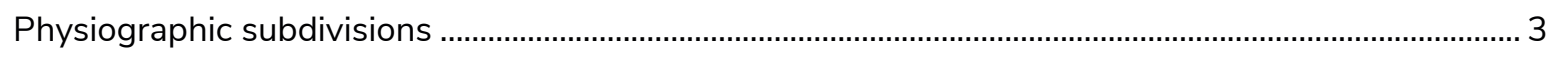

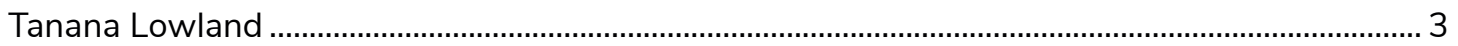

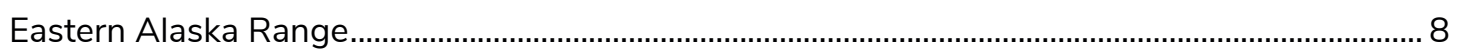

Southern Yukon-Tanana Upland ................................................................................................. 10

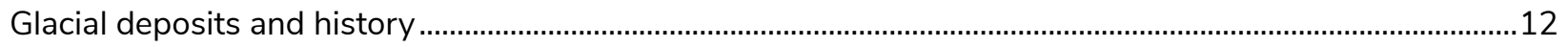

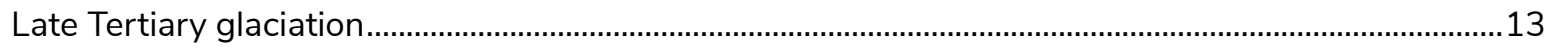

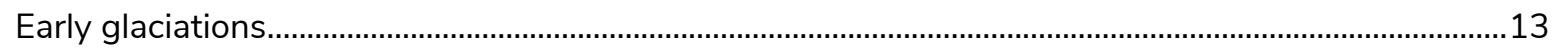

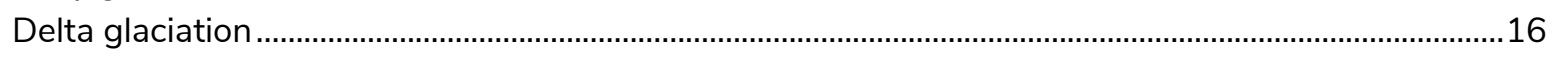

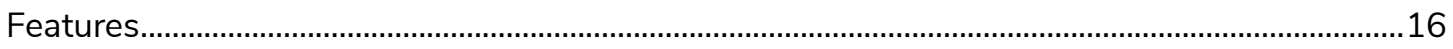

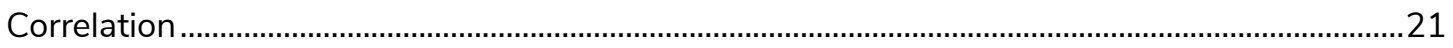

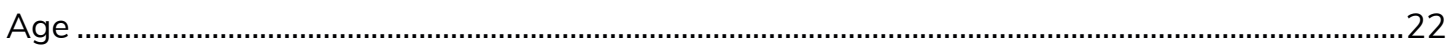

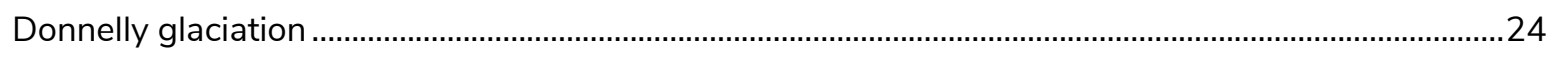

Features.

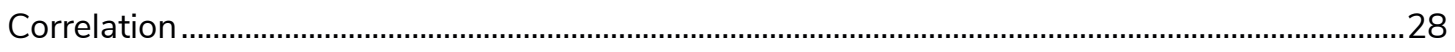

Age

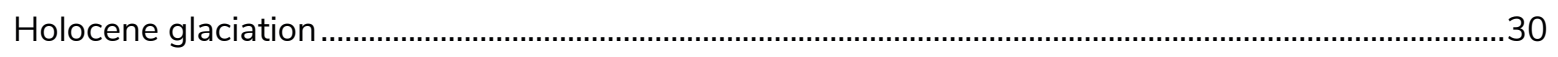

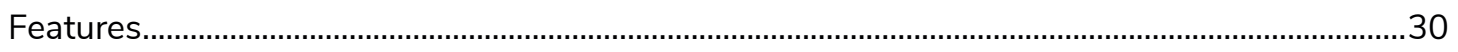

Age

Late Pleistocene paleofloods .........................................................................................................................

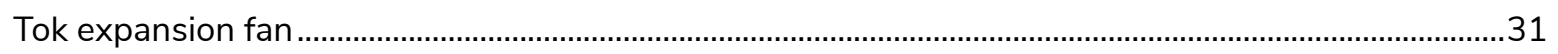

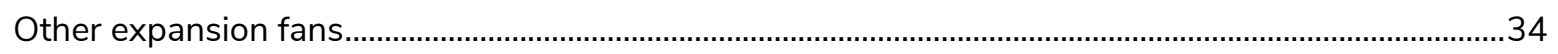

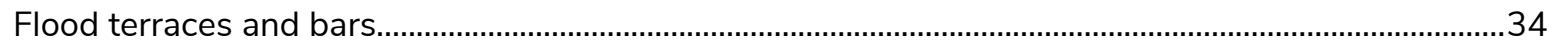

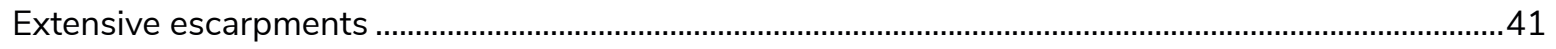

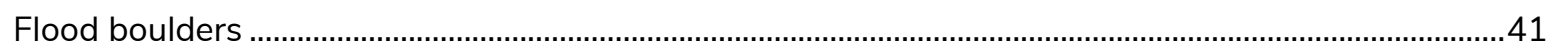

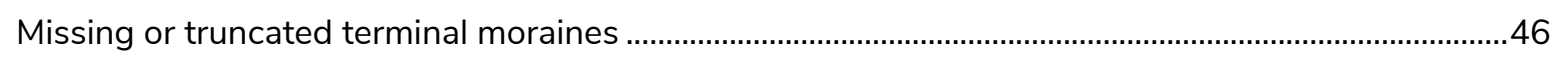

Flood-modified bedrock exposures....................................................................................................4

Proposed Jökulhlaup flood model .......................................................................................................

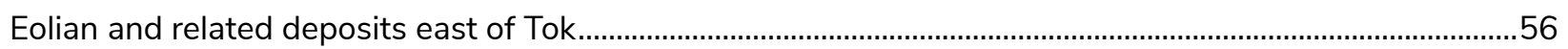

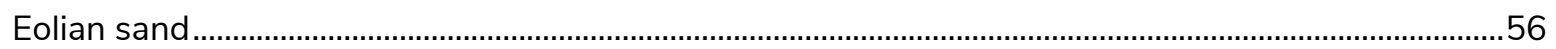

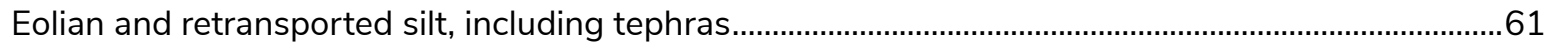

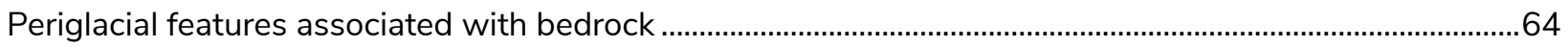

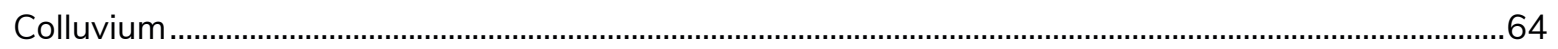

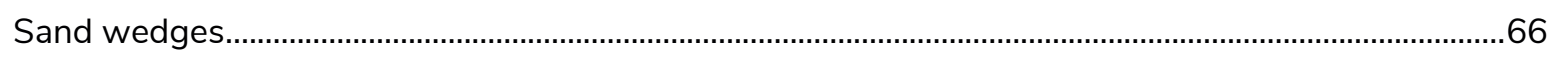

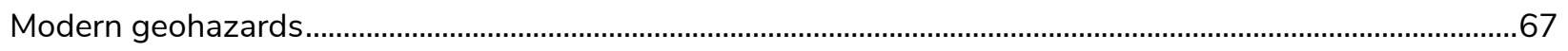

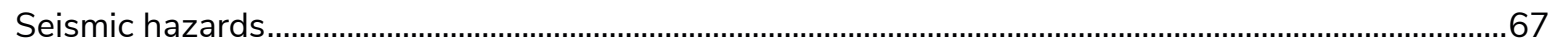

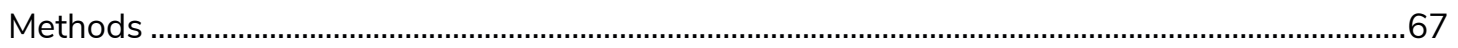

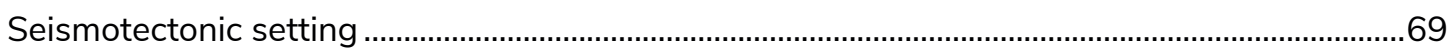

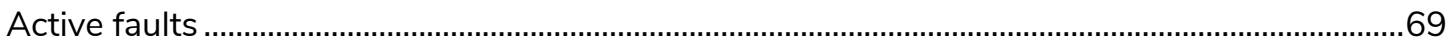

Granite Mountain-Panoramic fault ..........................................................................................

Granite Mountain segment of Dot “T” Johnson fault ..................................................................

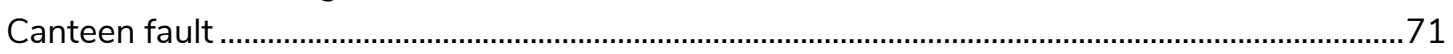

Dot Lake segment of Dot "T" Johnson fault...................................................................................

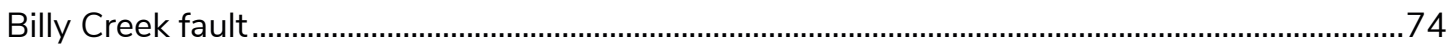

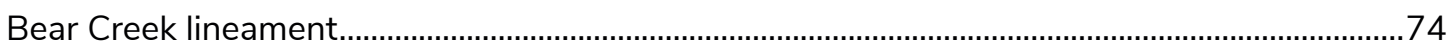




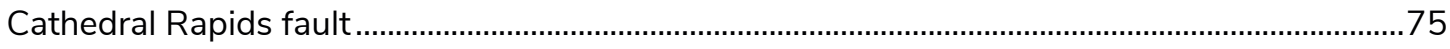

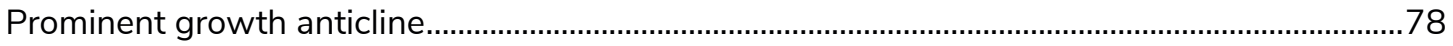

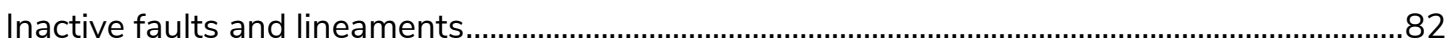

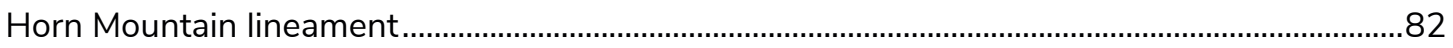

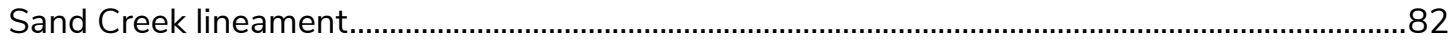

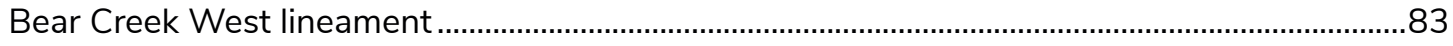

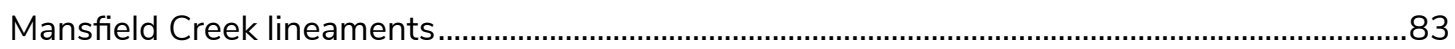

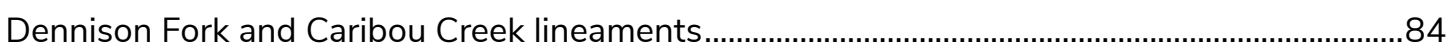

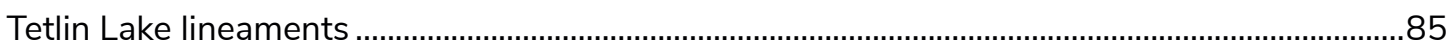

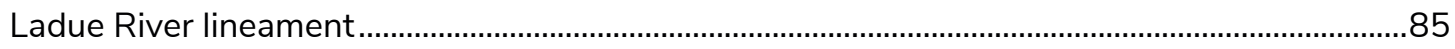

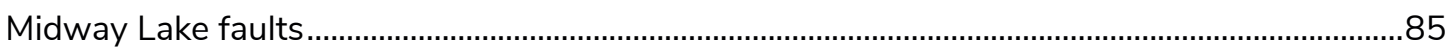

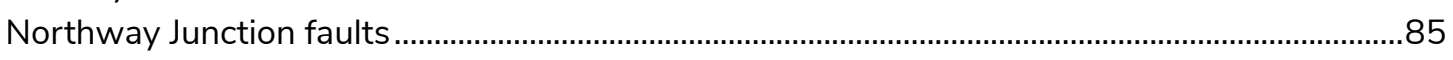

Airs Hills faults .

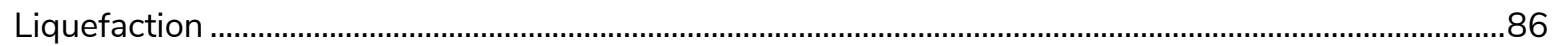

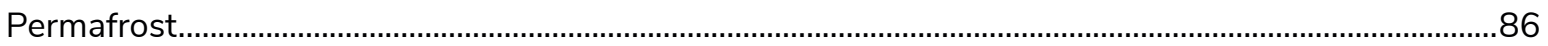

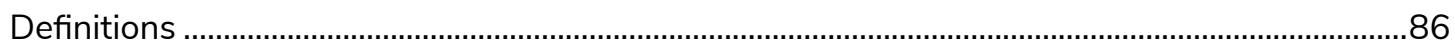

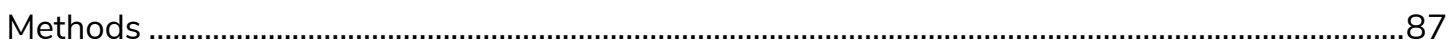

Factors affecting the distribution and disturbance of corridor permafrost ..................................89

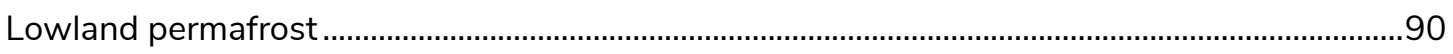

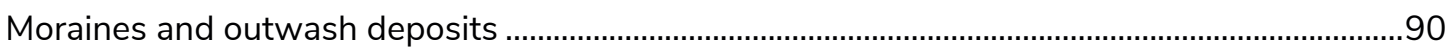

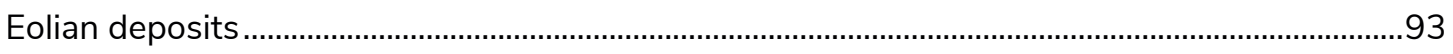

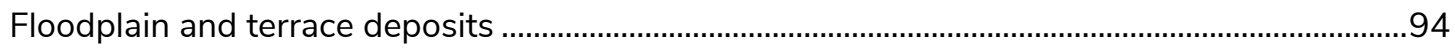

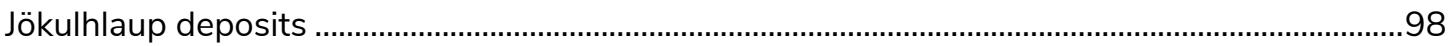

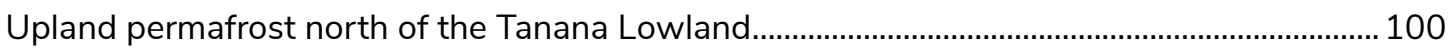

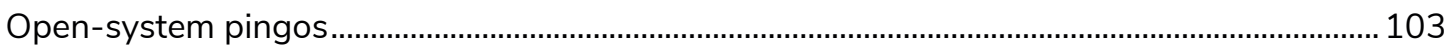

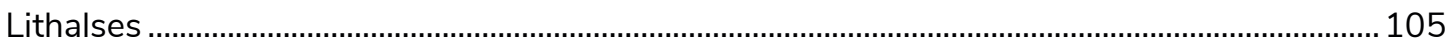

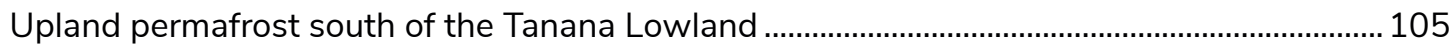

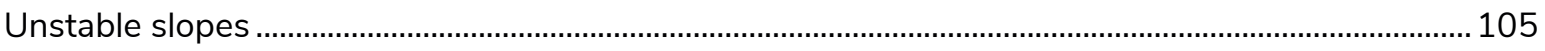

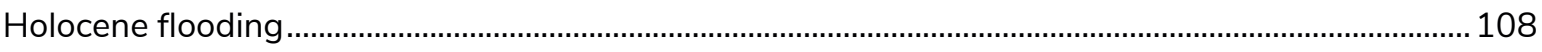

Summary

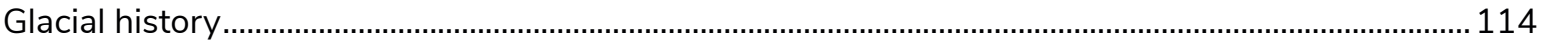

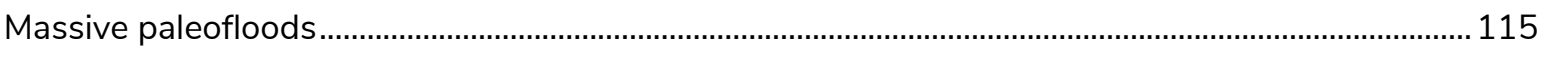

Eolian and related deposits............................................................................................................... 116

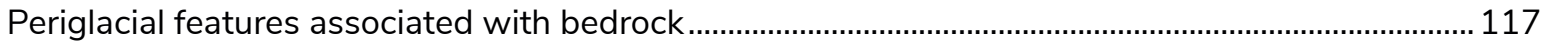

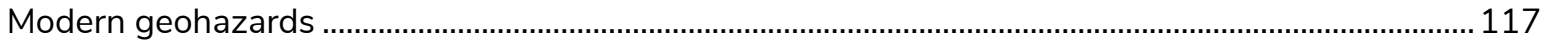

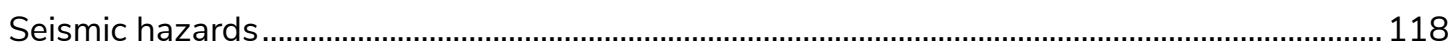

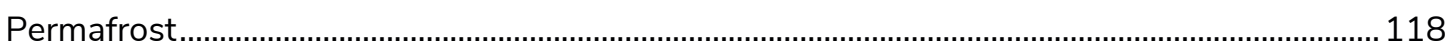

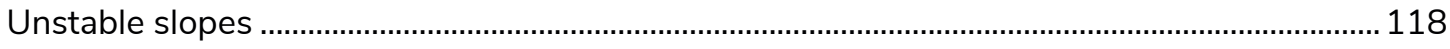

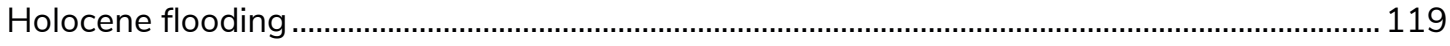

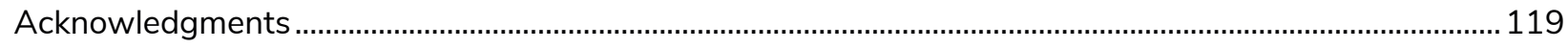

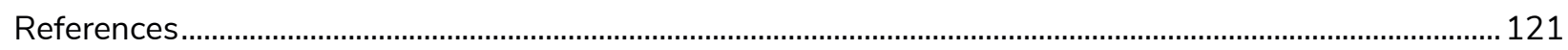

\section{Appendices}

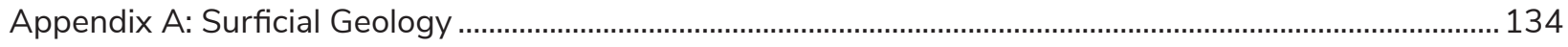

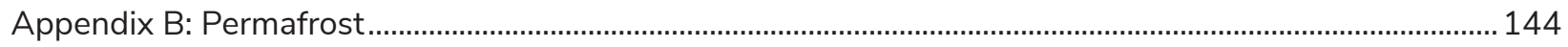

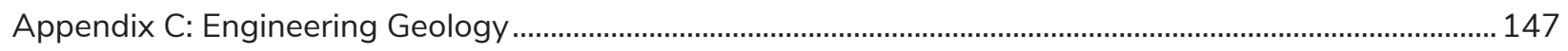




\section{Figures}

Figure 1. Location of Alaska Highway corridor in east-central Alaska.

Figure 2. Vertical false-color infrared aerial photograph showing fluvial, eolian, and thermokarst features near Midway Lake.

Figure 3. Aerial view southward of granitic tors in Knob Ridge area

Figure 4. Topographic profile A-A' from summit of Mount Neuberger southeastward across the Tok River valley

Figure 5. Physiographic features demonstrating piracy by Gardiner Creek of headwaters of much longer former course of Scotty Creek

Figure 6. Aerial view northeastward of lake impounded behind parabolic sand dunes.................................12

Figure 7. Tilted glacial or jökulhlaup deposits in upper Nenana Gravel of Pliocene age

Figure 8. View northeastward of subrounded to rounded granitic core stones and weathered granitic bedrock in quarry near mouth of Porcupine Creek

Figure 9. Aerial view westward of Clearwater Lake escarpment

Figure 10. View northward of alpine tundra at 1,325 m elevation on Macomb Plateau

Figure 11. View southeastward of granitic knobs scoured by glacial ice during Delta glaciation of Macomb Plateau at head of Dry Creek.

Figure 12. Aerial view southeastward of early and late end moraines of Delta glaciation, upper Dry Creek valley

Figure 13. Cirques of Delta and Donnelly glaciations cut into northern margin of Macomb Plateau.

Figure 14. Vertical false-color infrared aerial photograph showing estimated maximum height of glacial ice against Tower Bluffs during Delta glaciation.

Figure 15. Bare-earth lidar-DEM-derived profile of outwash surface from type Donnelly terminal moraine

Figure 16. Oblique bare-earth lidar-derived hillshade image looking southwestward toward the massive, bulbous late Wisconsin (Donnelly) terminal moraine of the Johnson River glacier...

Figure 17. Bluff exposure of Donnelly glacial deposits along lower Johnson River

Figure 18. Cross section showing physiographic and geologic relations along Alaska Highway at crossing of Berry Creek.

Figure 19. Vertical false-color infrared aerial photograph comparing surface forms of Robertson River moraines of Delta and Donnelly ages

Figure 20. Map showing course of outburst floods from Mentasta Pass to Tok expansion fan during Donnelly glaciation.

Figure 21. Extraordinarily large in-situ greenstone flood boulder in clast- and matrix-supported jökulhlaup gravels.

Figure 22. Bare-earth lidar-derived hillshade image across the Tok expansion fan along the Alaska Highway, showing multiple channels active during late Donnelly jökulhlaups

Figure 23. Vertical false-color infrared aerial photograph showing landforms related to largemagnitude flooding of upper Tanana River

Figure 24. Aerial view northwestward of streamlined flood terraces of Donnelly age....................................38

Figure 25. River-bluff exposure of pebbly sand flood deposits

Figure 26. Vertical false-color infrared aerial photograph showing landforms related to largemagnitude flooding of upper Tanana River

Figure 27. Ice-wedge cast in pebble-cobble gravel of Donnelly age in tilted longitudinal flood bar

Figure 28. Oblique bare-earth lidar-derived hillshade image showing surface of Donnelly longitudinal flood bar with surface ripples. 
Figure 29. Road cuts along Alaska Highway expose cross sections through pebbly sand waves (flood ripples) on tilted longitudinal flood bar.

Figure 30. Comparison photographs of high-level weathered, polymictic Delta-age flood gravel containing 1.5-m granitic flood boulder and with boulder missing in abandoned gravel pit...

Figure 31. Westward extension of Clearwater Lake escarpment across the southern Tanana River valley to the vicinity of Blair Lakes

Figure 32. Vertical false-color infrared aerial photograph showing landforms related to largemagnitude Delta and Donnelly flooding and the Dot "T" Johnson fault trace in Sears CreekBerry Creek area

Figure 33. Bare-earth lidar DEM-derived topographic profile B-B' across 3.2-km-wide Tanana River valley east of Berry Creek

Figure 34. View northward of a 15-m-high, prow-shaped granitic outcrop washed clean of former grus cover by large-magnitude paleofloods in Black Lake area..

Figure 35. Map showing landforms along route of outburst torrents flooding up lower Slana River valley through Mentasta Pass to Little Tok River.....

Figure 36. Vertical false-color infrared aerial photograph showing relations of radiocarbon sample localities RC-6 and RC-7 to Cobb Lakes end moraine

Figure 37. Proposed jökulhlaup flood model for lower Slana River-Station Creek drainages

Figure 38. Bare-earth lidar-derived hillshade scene showing pitted kame-terrace deposits and flood-scoured glacial drift in main jökulhlaup path near Mentasta Pass .

Figure 39. Roadcut exposure of kame-terrace flood gravels overlying massive sand above Donnelly till with Alaska Range erratics.

Figure 40. Bare-earth topographic profile C-C' from IFSAR-derived DEM across 1.8-km-wide Mentasta Pass.

Figure 41. Vertical false-color infrared aerial photograph showing flood-modified Mineral Lake end moraine and associated landforms

Figure 42. Gravel-pit exposure of crudely bedded jökulhlaup gravels in Little Tok River valley

Figure 43. Model of eolian processes and deposits during penultimate and last major glaciations in upper Nabesna-Chisana rivers lowland

Figure 44. Vertical false-color infrared aerial photograph of Tetlin Junction dune field.

Figure 45. Rounded, weathered granitic tor standing above eolian sand blanket in Material Site 62-1-019-5 north of AMP 1280.4 ....

Figure 46. Profile (SP-14) showing soil layers formed by weathering in eolian section exposed in Material Site 62-1-020-5 on ridge crest north of AMP 1276.0.

Figure 47. Vertical false-color infrared aerial photograph showing stabilized, frozen sand dunes and retransported eolian sediments in Gardiner Creek lowland.

Figure 48. Aerial view southwestward of stabilized sand dunes in Gardiner Creek lowland.

Figure 49. View north-northeastward of roadcut exposure of stratigraphic section 96TOK1 near AMP 1284.0

Figure 50. Generalized stratigraphic section 96TOK1...

Figure 51. Sand wedges in weathered granitic bedrock formerly exposed in roadcut near AMP 1303.0

Figure 52. Sand-wedge filling of mixed eolian sand and angular fragments of weathered granitic bedrock in sand wedge in weathered granitic bedrock formerly exposed in roadcut near AMP 1303.0.

Figure 53. Map showing principal faults, lineaments, and trenches studied during DGGS paleoseismic investigations in and near the Alaska Highway corridor.. 
Figure 54. Oblique aerial photograph toward northwest of Donnelly and Delta lateral moraines

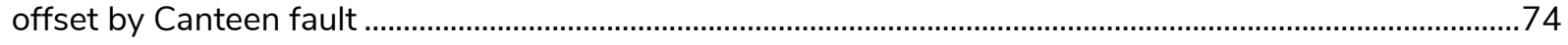

Figure 55. Profiles of deformed longitudinal flood bar and floor of upper Sam Creek valley..........................75

Figure 56. Stratigraphic logs of east and west walls in trench DTJ I...................................................................76

Figure 57. Stratigraphic logs of east and west walls in trench DTJ III ..............................................................77

Figure 58. Stratigraphic logs in east and west walls of Sears Creek trench across

Dot "T" Johnson fault.

Figure 59. Lidar image and oblique aerial photograph of scarp along Cathedral Rapids fault.....................80

Figure 60. Stratigraphic log and photograph in east wall in trench T-1 across Cathedral Rapids fault......81

Figure 61. Oblique aerial photograph looking southeastward at northwestern segment of large fault-propagated growth anticline along base of piedmont slope...

Figure 62. Differential GPS longitudinal profiles of modern thalweg of Catastrophe Creek and deformed fluvial terraces across large, fault-propagated growth anticline and Cathedral Rapids fault scarp.

Figure 63. Stratigraphic logs of east and west walls in trench GMT I across Cathedral Rapids fault

Figure 64. A series of low sand cones with central pits aligned along runway edge at Northway airport

Figure 65. Profile D-D', segment of multilayer-inversion model EM1DFM 15290 and interpretive permafrost map of eastern Desper-Scotty creeks lowland.

Figure 66. Generalized ground-temperature profile in area of permafrost.

Figure 67. Evolution of shallow lakes on floodplains of meandering streams by thermokarst activity in a permafrost environment.

Figure 68. General relations of floodplain landforms, deposits, permafrost, and flood frequency in meandering reach of Tanana River

Figure 69. Factors influencing expansion of thaw lakes through bank recession

Figure 70. Evolution of thaw lakes in Nabesna-Chisana rivers area, Northway lowland

Figure 71. Vertical false-color infrared aerial photograph showing natural levee-lake delta complexes

Figure 72. Vertical false-color infrared aerial photograph showing permafrost-related landforms in Sand Lake area.

Figure 73. Typical sedge tussock and scattered black spruce vegetation growing above shallow, continuous permafrost on floor of upper Ladue River valley,

Figure 74. Pair of open-system pingos on perennially frozen lower slope of upper Ladue River valley.....

Figure 75. Evolution of open-system pingos

Figure 76. Dense willow and resin birch shrubs with scattered stunted black spruce trees in foreground growing on perennially frozen colluvial-alluvial fill in valley bottom

Figure 77. Aerial view northwestward of large, arcuate, thaw-induced, retrogressive failure that intersected the Alaska Highway near AMP 1267

Figure 78. Aerial view of moderate-sized, active failure in weathered granitic bedrock on northern wall of Gardiner Creek canyon

Figure 79. View westward up Robertson River from north end of highway bridge, showing thick winter stream icing.

Figure 80. Cross-beds in sand and sandy pebble-gravel fill in shallow channel on Tok River alluvial fan east of Tok River

Figure 81. Aerial view northwestward of natural levee and slackwater basin inundated by flooding Chisana River. 
Figure 82. Interpretive diagram based on borings drilled in and near footprint of bridge \#505 over Tanana River at AMP 1303.3

Figure 83. Map showing Holocene expansion-fan and slackwater-basin complex in Fish LakeWolf Lake area

Figure 84. Vertical false-color infrared aerial photograph showing features related to largemagnitude flooding of upper Tanana River in Black Lake area

Figure 85. Curved stems of alder shrubs tilted and broken during 1997 deposition of natural levee along unnamed small stream above Alaska Highway

Figure 86. View southward up floodplain of Yerrick Creek toward Alaska Highway bridge, showing numerous large boulders deposited by torrential flooding.

\section{Tables}

Table 1. Summary of radiocarbon dates associated with Quaternary deposits in the Alaska Highway corridor

Table 2. Comparison of Quaternary glacial chronologies in the eastern Alaska Range, YukonTanana Upland, and western Yukon Territory

Table 3. Comparison of jökulhlaup paleochannel networks on Tok expansion fan

Table 4. Jökulhlaup discharge data derived from lidar, AIRSAR, and IFSAR digital-elevation models (DEMs) using ArcGIS and Grapher for profiles B-B' and C-C'.

Table 5. Gravimetric soil moisture in frozen samples of eolian sand, loess, and retransported silt and sand in the Alaska Highway corridor.

Table 6. Summary of distal rhyolitic tephras in and near the Alaska Highway corridor

Table 7. Average annual air temperatures at settlements in the Alaska Highway corridor between Delta Junction and the Canada border. 


\section{MAP SHEETS}

\section{SURFICIAL-GEOLOGY MAPS}

1 Surficial-geologic map, Alaska Highway corridor, Delta Junction, Alaska, to the Canada border; segment 1 west

2 Surficial-geologic map, Alaska Highway corridor, Delta Junction, Alaska, to the Canada border; segment 1 east

3 Surficial-geologic map, Alaska Highway corridor, Delta Junction, Alaska, to the Canada border; segment 2 west

4 Surficial-geologic map, Alaska Highway corridor, Delta Junction, Alaska, to the Canada border; segment 2 east

5 Surficial-geologic map, Alaska Highway corridor, Delta Junction, Alaska, to the Canada border; segment 3 west

6 Surficial-geologic map, Alaska Highway corridor, Delta Junction, Alaska, to the Canada border; segment 3 east

\section{INTERPRETIVE PERMAFROST MAPS}

7 Interpretive permafrost map, Alaska Highway corridor, Delta Junction, Alaska, to the Canada border; segment 1 west

8 Interpretive permafrost map, Alaska Highway corridor, Delta Junction, Alaska, to the Canada border; segment 1 east

9 Interpretive permafrost map, Alaska Highway corridor, Delta Junction, Alaska, to the Canada border; segment 2 west

10 Interpretive permafrost map, Alaska Highway corridor, Delta Junction, Alaska, to the Canada border; segment 2 east

11 Interpretive permafrost map, Alaska Highway corridor, Delta Junction, Alaska, to the Canada border; segment 3 west

12 Interpretive permafrost map, Alaska Highway corridor, Delta Junction, Alaska, to the Canada border; segment 3 east

\section{ENGINEERING-GEOLOGIC MAPS}

13Engineering-geologic map, Alaska Highway corridor, Delta Junction, Alaska, to the Canada border; segment 1 west

14Engineering-geologic map, Alaska Highway corridor, Delta Junction, Alaska, to the Canada border; segment 1 east

15Engineering-geologic map, Alaska Highway corridor, Delta Junction, Alaska, to the Canada border; segment 2 west

16 Engineering-geologic map, Alaska Highway corridor, Delta Junction, Alaska, to the Canada border; segment 2 east

17 Engineering-geologic map, Alaska Highway corridor, Delta Junction, Alaska, to the Canada border; segment 3 west

18 Engineering-geologic map, Alaska Highway corridor, Delta Junction, Alaska, to the Canada border; segment 3 east 



\title{
SURFICIAL GEOLOGY AND GEOHAZARDS IN THE ALASKA HIGHWAY CORRIDOR, ALASKA
}

Richard D. Reger ${ }^{1}$, Trent D. Hubbard², and Rich D. Koehler ${ }^{3}$

\begin{abstract}
The Alaska Division of Geological \& Geophysical Surveys (DGGS) conducted field investigations in the Alaska Highway corridor from Delta Junction to the Canada border to support future infrastructure decisions. We used airphoto and lidar interpretations, helicopter surveys, and ground reconnaissances to perform detailed Quaternary geologic mapping and evaluate potential geohazards. This report compiles the Division's field mapping from 2006 through 2012 and details the Quaternary depositional history and geohazards in the corridor.

South of the Tanana River, we mapped deposits associated with marine-isotope stages (MIS) 2, 4, and 6 glaciations sourced in the eastern Alaska Range. In the upper Tanana River drainage, episodic voluminous jökulhlaups produced the broad Tok and other expansion fans, crevassesplay complexes associated with slackwater basins, streamlined flood terraces and bars, floodscoured bedrock outcrops, and extensive flood escarpments. Stratigraphic analyses of depositional landforms indicate that they were deposited by hyperconcentrated flows.

Widespread eolian sand dunes and blankets are overlain by thin loess, particularly in the southern Yukon-Tanana Upland. Southeast of Tok in the Upland, retransported sand and loess form complex, perennially frozen valley fills. Three large, arcuate, retrogressive landslides that are expanding toward the Alaska Highway by the thawing of frozen retransported loess and eolian sand forced rerouting of the road alignment near milepost 1267 in 2004.

Flood hazards in the corridor are associated with summer and early fall cyclonic storm cycles, summer melting of snow and ice fields, and winter buildup of extensive floodplain icings.

The active Northern Foothills Fold and Thrust Belt (NFFTB) roughly parallels the Alaska Highway southeastward through the corridor to the Tok River valley and bounds the northern margin of the eastern Alaska Range. We recognized active tectonic structures, as well as several potentially active lineaments in the NFFTB. Definitive evidence for Holocene activity was documented in paleoseismic trenches across the Dot " $T$ " Johnson and Cathedral Rapids faults. Potential future earthquakes in and near the corridor could generate surface fault rupture, strong ground shaking, liquefaction, slope failures, and other hazards.
\end{abstract}

\footnotetext{
${ }^{1}$ Reger's Geologic Consulting, P.O. Box 3326, Soldotna, AK 99669 (DGGS retired)

${ }^{2}$ Alaska Division of Geological \& Geophysical Surveys, 3354 College Road, Fairbanks, AK 99709-3707

${ }^{3}$ Alaska Division of Geological \& Geophysical Surveys, 3354 College Road, Fairbanks, AK 99709-3707; now at Nevada Bureau of Mines and Geology, Mackay School of Earth Science \& Engineering, University of Nevada, Reno, 1664 North Virginia Street, MS 178, Reno, NV 89557
} 


\section{INTRODUCTION}

The Alaska Highway corridor is an important landtransportation connection to interior Alaska from Canada and the contiguous United States and is likely to be the locus of future developments (Combellick, 2006). From 2006 through 2012, the Alaska Division of Geological \& Geophysical Surveys conducted reconnaissance geologic mapping and evaluated geohazards in the 322-km-long by $19-\mathrm{km}$-wide corridor centered on the Alaska Highway between Delta Junction and the Canada border (fig. 1). Those efforts resulted in numerous reports that describe the surficial geology, permafrost, active faulting, and engineering geology in the extensive corridor (Reger and others, 2008a, b, 2011, 2012a, b; Carver and others, 2008a, b, 2010; Reger and Solie, 2008a, b; Reger and Hubbard, 2009, 2010; Hubbard and Reger, 2010a, b; Hubbard and others, 2013; Koehler and Carver, 2012; Koehler and Woods, 2013). In this final, comprehensive report we summarize these investigations and incorporate new knowledge accumulated during later field- and lidarbased investigations. Associated maps delineate surficial geology, interpretive permafrost distribution, and engineering geology. Map data are also available digitally as seamless Geographic Information System (GIS) geospatial data files.

\section{PHYSIOGRAPHY AND SURFICIAL GEOLOGY}

\section{Methods}

We initially mapped surficial geology by interpreting stereoscopic pairs of $\sim$ 1:65,000-scale, false-color, infrared aerial photographs taken in July 1978, August 1980, August 1981, and July 1983, and plotting unit boundaries on acetate overlays. During this initial survey, we gave special attention to identifying geologic processes and conditions with the potential to negatively impact future development in the corridor, including active faults, permafrost, mass-movement features, and areas prone to flooding

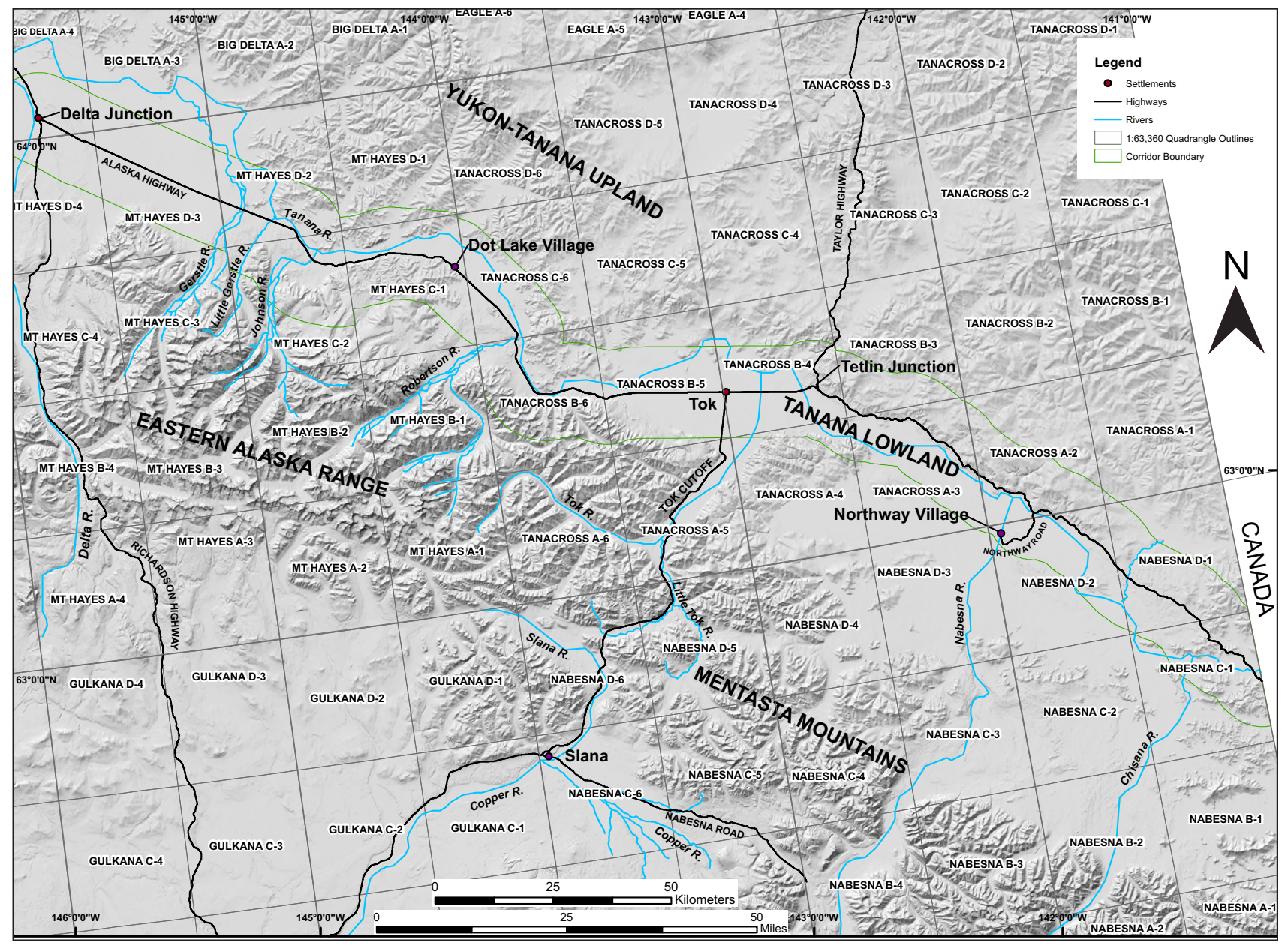

Figure 1. Location of Alaska Highway corridor (outlined by green line) in east-central Alaska. 
and liquefaction. We also identified potential sources of construction materials and incorporated information from previous geologic reports. Verification of photo mapping was completed during field work in 2006-2012, when map units were described and samples collected for analyses. Following orthorectification of the aerial photographs and attached acetate overlays, we digitized unit boundaries onscreen using ArcGIS and prepared surficial-geologic maps (Reger and others, 2008a, 2011, 2012a) (sheets 1-6; Appendix A) and interpretive permafrost maps (Reger and Solie, 2008a; Reger and Hubbard, 2010; Reger and others, 2012b) (sheets 7-12; Appendix B). Using Geographic Information System (GIS) software, from the surficial-geology maps we subsequently derived engineering-geologic maps, which show the distribution of surficial-geologic and bedrock units grouped genetically with common properties that are typically significant for engineering purposes (Reger and Solie, 2008b; Hubbard and Reger, 2010a; Hubbard and others, 2013) (sheets 13-18; Appendix C).

After the initial photo interpretation and publication of the preliminary maps and reports, DGGS acquired airborne lidar (light-detection and ranging) data in 2010 and 2011 for $-7,770 \mathrm{~km}^{2}$ of the Alaska Highway corridor, mainly in a $1.6-\mathrm{km}$-wide strip centered along the Alaska Highway (Hubbard and others, $2011 \mathrm{a}, \mathrm{b}, \mathrm{c}, \mathrm{d}$ ). We used lidar data to create bare-earth digital elevation models (DEMs), which represent the bare ground surface by effectively removing the surface vegetation. The density of lidar data returns was sufficient to create high-quality hillshade images-grayscale 3D representations of the ground surface with the sun position taken into account for shading — with 1-m pixel resolution from bare-earth DEMs. The hillshade images proved to be the most useful type of remotely sensed data for identifying and characterizing landforms, and were especially helpful for locating potentially active faults and landforms related to slope instability in areas of dense vegetation and thick eolian sand (Hubbard and others, 2011e). Preliminary surficial-geologic mapping was improved by comparing our initial photointerpreted geologic maps with the highresolution lidar hillshade images. Evaluating the lidar images considerably enhanced our understanding of the history of extensive late-Pleistocene outburst flooding in the upper Tanana River drainage. We confirmed and identified numerous flood-related landforms and constructed topographic profiles using bare-earth DEMs that allowed us to estimate paleoflood-flow parameters.
We compiled previously published radiocarbon data and combined those data with atomic mass-spectrometer (AMS) radiocarbon dates obtained during this investigation. We have not updated previously published calibrated radiocarbon ages to maintain the integrity of those data and discussions. For this report, we calibrated previously uncalibrated radiocarbon ages online through the ${ }^{14}$ Chrono Centre, Queen's University Belfast using their Calib 7.0.1 calibration program and IntCal13 and Marine13 calibration curves (Reimer and others, 2013). For those newly calibrated ages, we report only the original radiocarbon ages and their associated median calibrated ages; however, limiting calibration values are also listed in table 1.

\section{Physiographic subdivisions}

The Alaska Highway corridor extends from Delta Junction in the northwest to the Canada border in the southeast through the Tanana Lowland between the northern flank of the eastern Alaska Range and the southern Yukon-Tanana Upland (Wahrhaftig, 1965) (fig. 1).

\section{Tanana Lowland}

Late Pleistocene glacial lobes in the central and eastern Alaska Range extended onto the margins of the Tanana Lowland, and from their terminal moraines, extensive, thick, granular outwash fans and aprons spread northward into the lowland, forcing the Tanana River against the southern margin of the Yukon-Tanana Upland (Péwé and Holmes, 1964; Wahrhaftig, 1965; Holmes and Péwé, 1965; Péwé and Reger, 1983a; Reger and Péwé, 2002; Carrara, 2004a, b). Thick, granular piedmont fans and aprons contain important aquifers that supply large volumes of groundwater in the corridor (Anderson, 1970; Williams, 1970; Dingman and others, 1971; Wilcox, 1980; Nelson, 1995).

Several large clearwater lakes, including Quartz Lake and Lake George, are impounded by flood-expansion fans that block re-entrants in the Yukon-Tanana Upland along the northern margin of the Tanana Lowland (Péwé and Reger, 1983a; Reger and Péwé, 2002; Reger and others, 2008a). Those impounded lakes receive water from groundwater aquifers and small, clear streams draining the unglaciated southern Yukon-Tanana Upland. However, during flooding of the Tanana River, flows in streams draining some lowland-marginal lakes (such as Sand and Black lakes) reverse, and turbid Tanana River floodwaters enter these lakes, building complex deltas (Reger and others, 2008a, figs. 25 and 33) (sheet 2). 


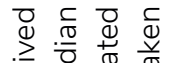

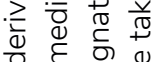
每

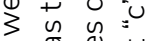

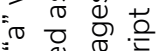

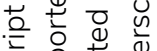

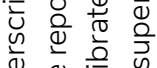

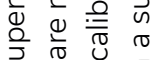

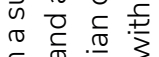

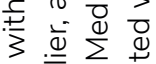

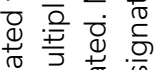
可

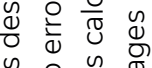

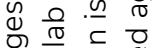

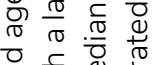

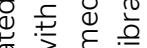

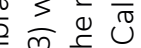

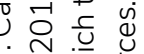

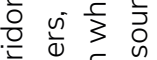

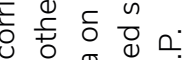

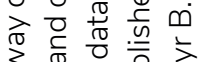

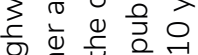

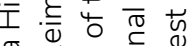

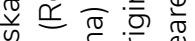

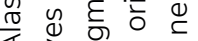

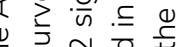

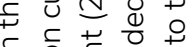

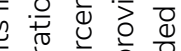
政 웡

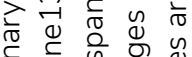

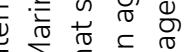

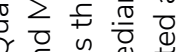

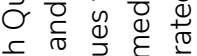
言品产

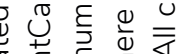
年 ज ह $\bar{\sigma} \frac{\sigma}{\sigma}$

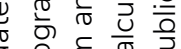

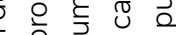

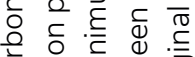
응 흘 음

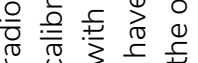
क्ष

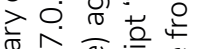

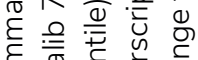
言它 要

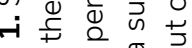

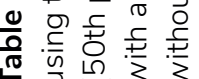

\begin{tabular}{|c|c|c|c|c|c|c|c|c|c|c|c|c|c|c|}
\hline 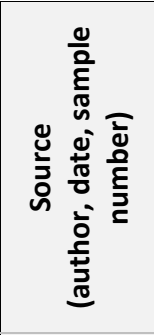 & 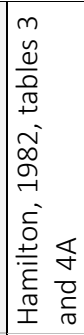 & 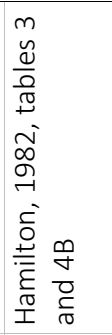 & 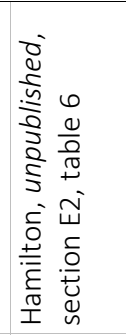 & 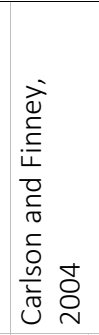 & & 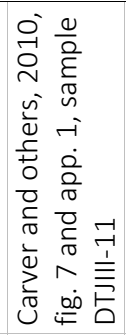 & 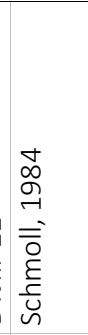 & 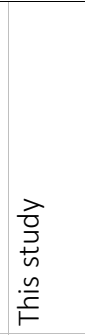 & 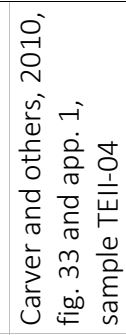 & 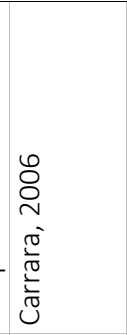 & 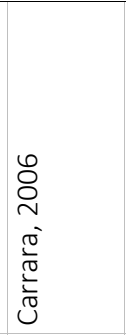 & 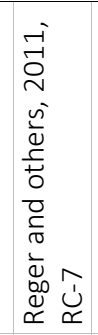 & 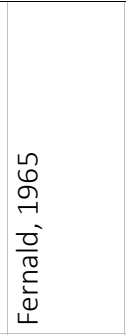 & 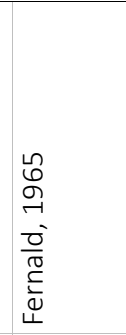 \\
\hline 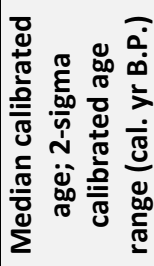 & 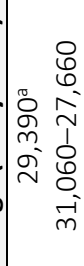 & 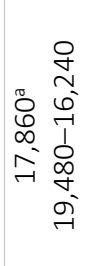 & 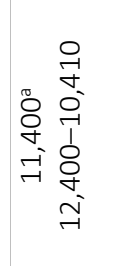 & 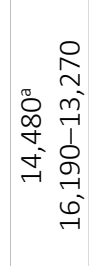 & 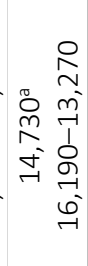 & 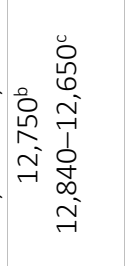 & 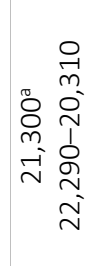 & 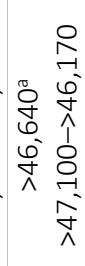 & 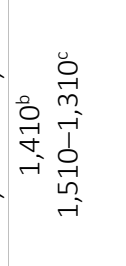 & 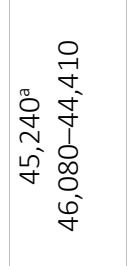 & 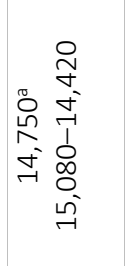 & $\begin{array}{ll} & 8 \\
& 8 \\
0 & 0 \\
0 & 0 \\
0 & 1 \\
0 & 0 \\
0 & 1 \\
\text { an } & \end{array}$ & 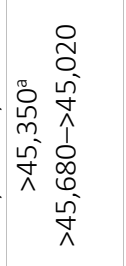 & 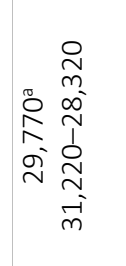 \\
\hline 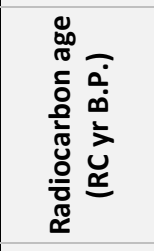 & 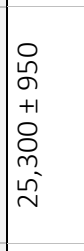 & 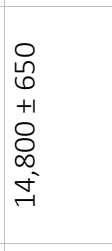 & $\begin{array}{l}\stackrel{D}{N} \\
m \\
+1 \\
\infty \\
\infty \\
\infty \\
\sigma\end{array}$ & $\begin{array}{l}0 \\
\stackrel{1}{ } \\
+1 \\
0 \\
\stackrel{+}{+} \\
\stackrel{+}{\exists}\end{array}$ & \begin{tabular}{l}
$\stackrel{9}{+}$ \\
+1 \\
$o$ \\
$m$ \\
$\stackrel{+}{+}$ \\
\multirow{1}{*}{}
\end{tabular} & $\begin{array}{l}0 \\
1 \\
+1 \\
8 \\
0 \\
6 \\
0 \\
-1\end{array}$ & $\begin{array}{l}8 \\
\vdots \\
+1 \\
8 \\
8 \\
b \\
-1\end{array}$ & $\begin{array}{l}8 \\
\stackrel{8}{0} \\
\stackrel{n}{m} \\
\stackrel{x}{x}\end{array}$ & $\begin{array}{l}9 \\
+1 \\
+1 \\
8 \\
\stackrel{1}{-1} \\
-1\end{array}$ & 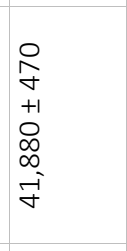 & 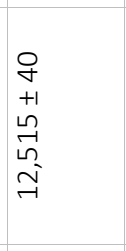 & $\begin{array}{l}\text { O } \\
+1 \\
8 \\
8 \\
\stackrel{-}{1} \\
\infty\end{array}$ & \begin{tabular}{l}
8 \\
8 \\
$\tilde{y}$ \\
\multirow{1}{*}{}
\end{tabular} & $\begin{array}{l}8 \\
\infty \\
+1 \\
8 \\
\varnothing \\
\infty \\
\end{array}$ \\
\hline 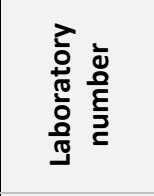 & 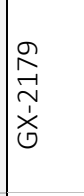 & 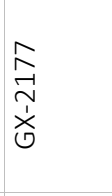 & $\begin{array}{l}\infty \\
\stackrel{\infty}{\overrightarrow{1}} \\
\underset{\tilde{N}}{\mathbb{v}}\end{array}$ & 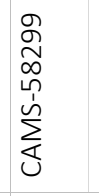 & 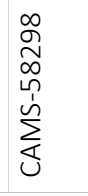 & 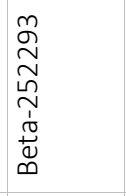 & $\begin{array}{l}\stackrel{+}{7} \\
\stackrel{-}{7} \\
\stackrel{3}{3}\end{array}$ & 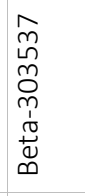 & 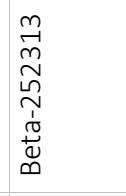 & 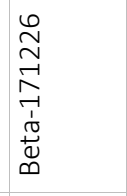 & $\begin{array}{l}-1 \\
0 \\
\infty \\
m \\
m \\
3\end{array}$ & 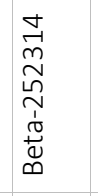 & $\begin{array}{l}0 \\
\frac{1}{a} \\
\vdots \\
3\end{array}$ & \begin{tabular}{l}
+ \\
\multirow{7}{7}{} \\
$\overrightarrow{3}$ \\
3
\end{tabular} \\
\hline 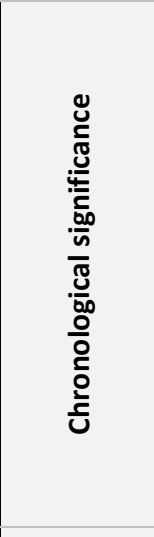 & 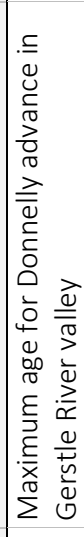 & 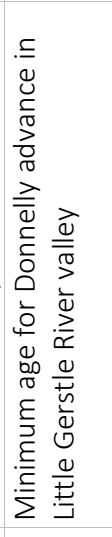 & 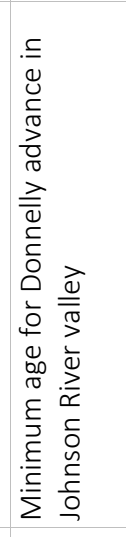 & 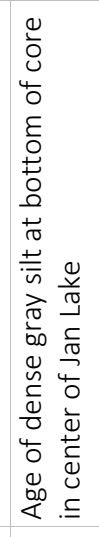 & & 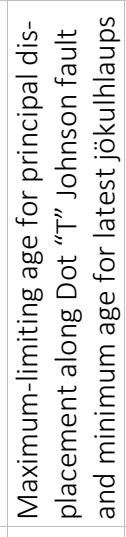 & 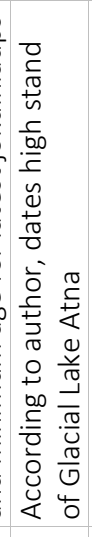 & 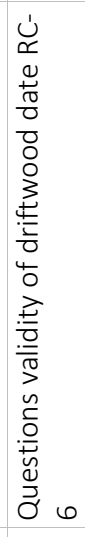 & 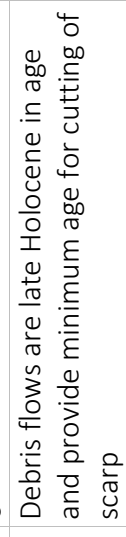 & 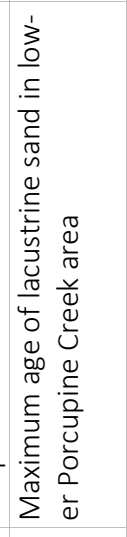 & 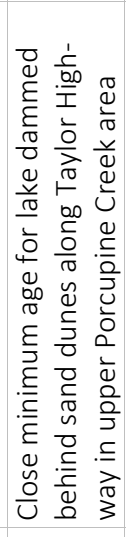 & 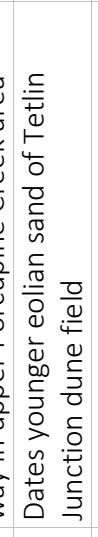 & 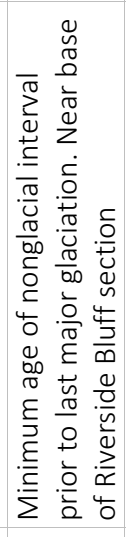 & 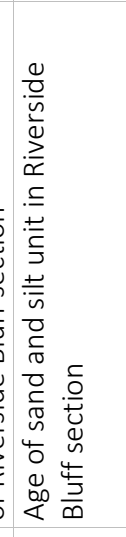 \\
\hline 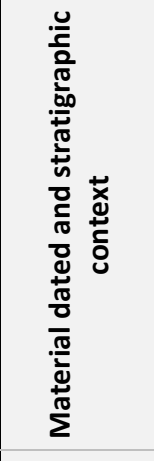 & 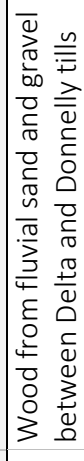 & 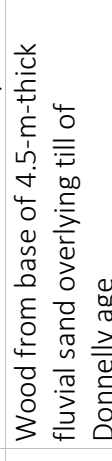 & 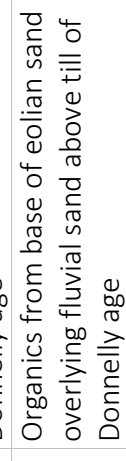 & 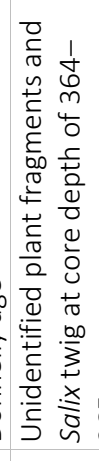 & & 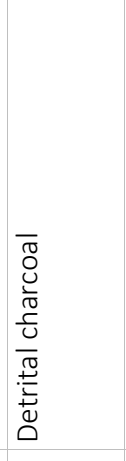 & 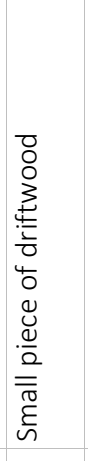 & 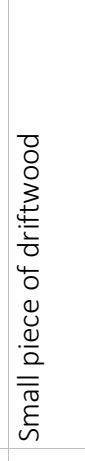 & 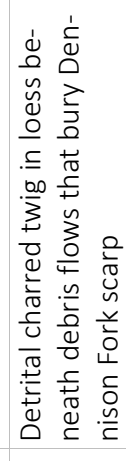 & 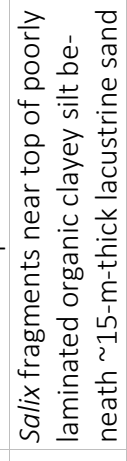 & 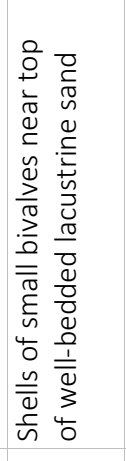 & 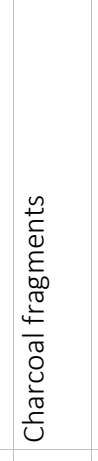 & 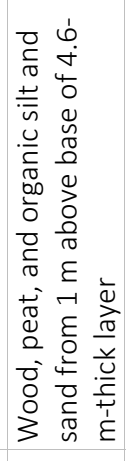 & 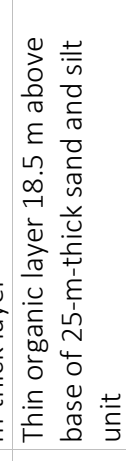 \\
\hline 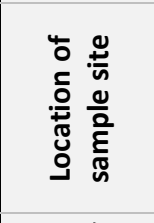 & 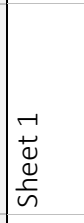 & $\begin{array}{l}\sim \\
\stackrel{u}{u} \\
d \\
\mathcal{U} \\
\omega\end{array}$ & $\begin{array}{l}\sim \\
\stackrel{\Xi}{ \pm} \\
\stackrel{\sim}{\sim} \\
\sim\end{array}$ & $\begin{array}{l}m \\
\stackrel{u}{d} \\
d \\
\mathcal{N} \\
\omega\end{array}$ & & 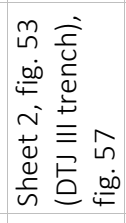 & & 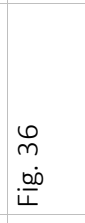 & 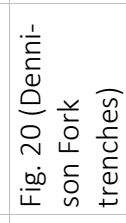 & $\frac{⿱}{\Delta}$ & 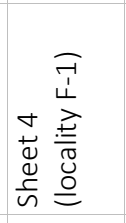 & 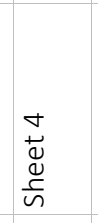 & 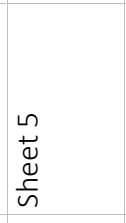 & 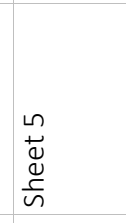 \\
\hline 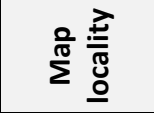 & 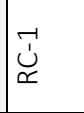 & 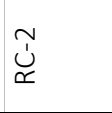 & $\bigcup_{\approx}^{n}$ & $\underbrace{+}_{\propto}$ & & 足 & $\begin{array}{l}\varphi \\
\dot{u} \\
\propto\end{array}$ & $\hat{u}_{\propto}$ & ${ }_{\mathscr{\chi}}^{\infty}$ & 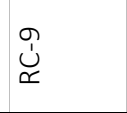 & 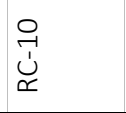 & $\begin{array}{l}\overrightarrow{\mid} \\
\vec{u} \\
\propto\end{array}$ & $\begin{array}{l}\text { ᄀี } \\
\dddot{u}\end{array}$ & $\underset{\ddot{u}}{m}$ \\
\hline
\end{tabular}




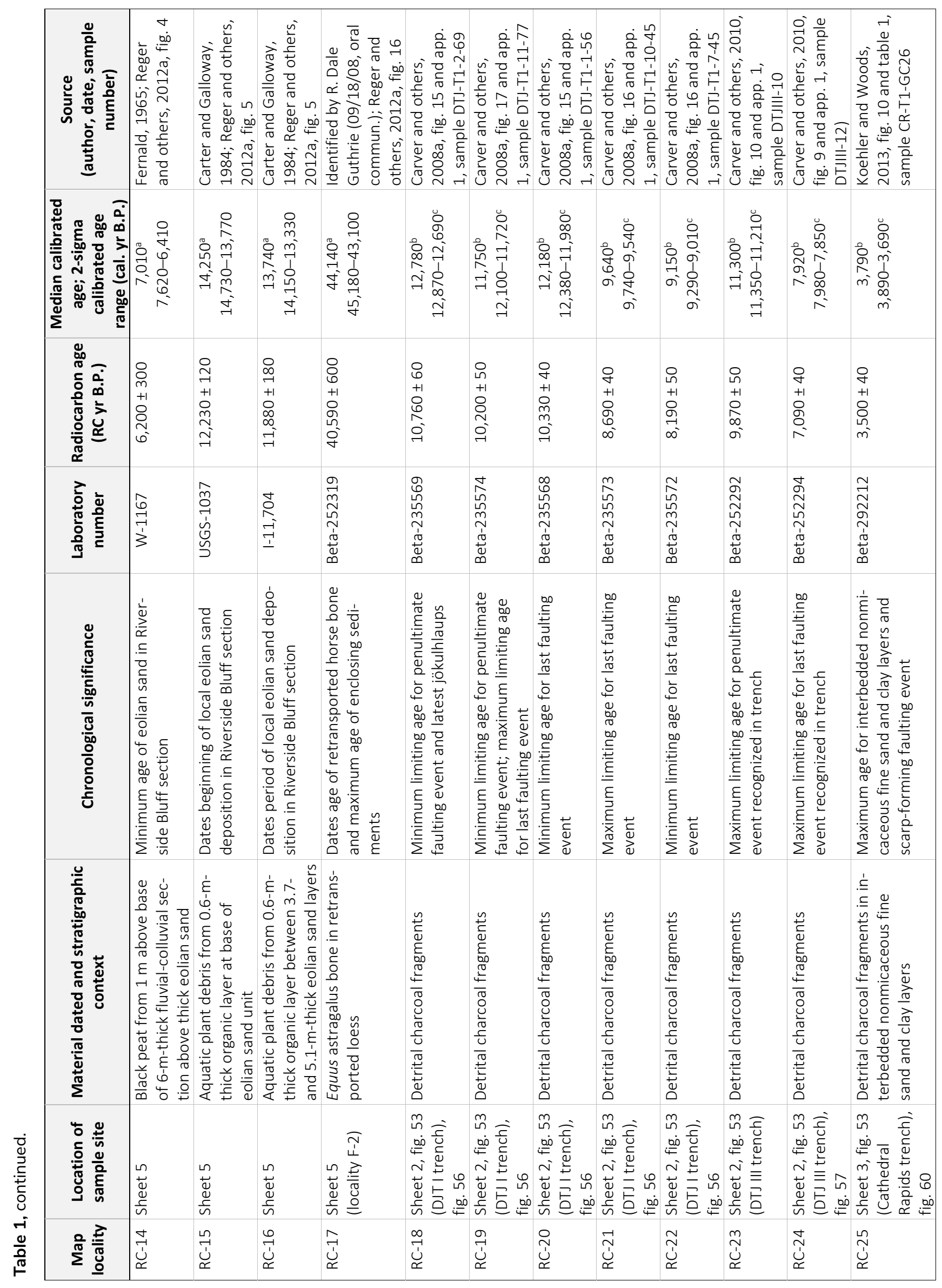




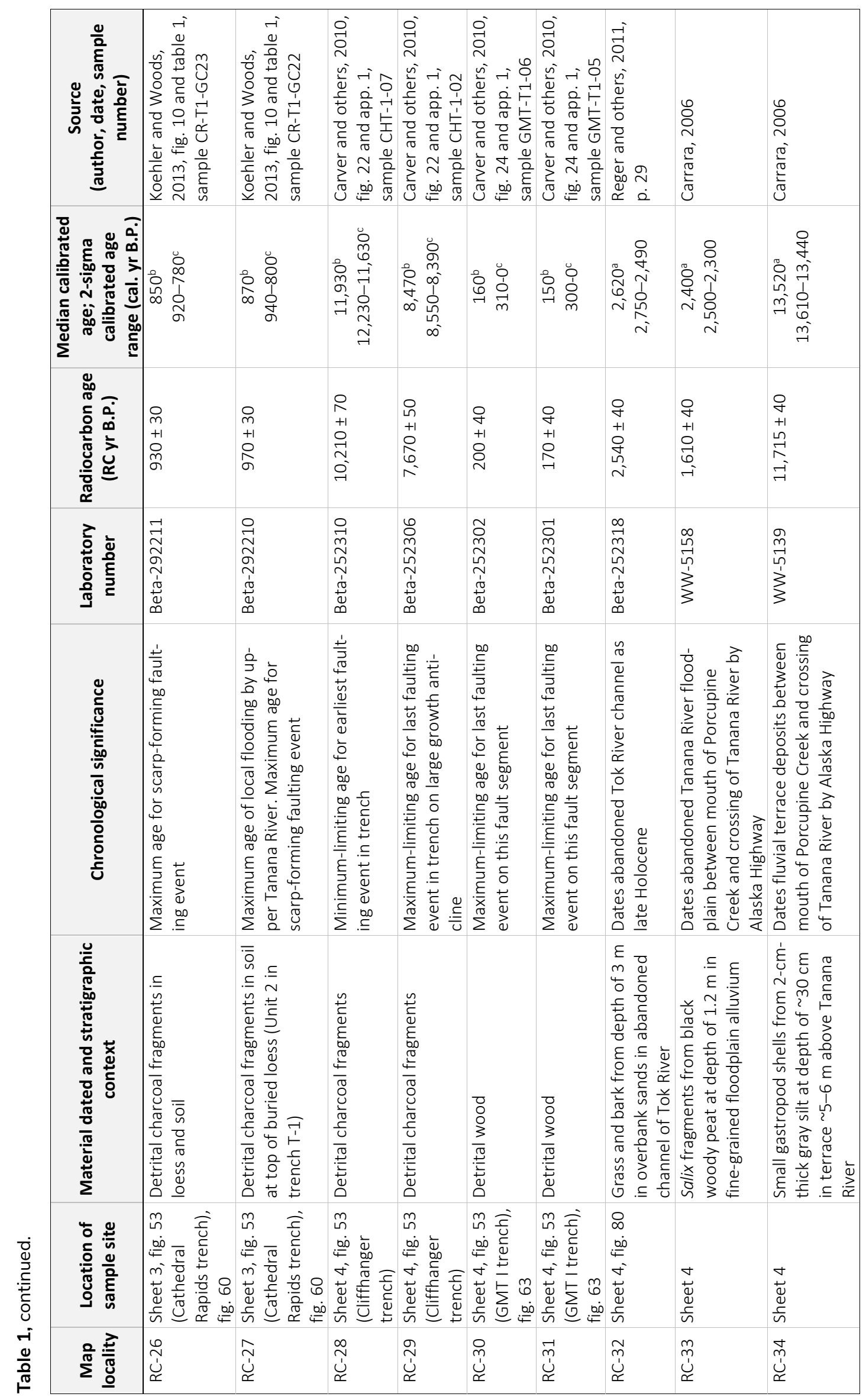


The principal drainage through the Tanana Lowland is provided by the Tanana River, a large, turbid, axial meltwater stream that is variously braided, anastomosing, or meandering along its course, depending on the volumes of sediment fed into it by tributaries flowing northward from the Alaska Range. The floodplain of the Tanana River through the western corridor ranges in width from 0.8 to $6.4 \mathrm{~km}$ and features active channels with numerous alluvial bars, inactive and abandoned floodplain surfaces, and low river terraces (sheets 1-3). Large, sediment-charged, braided tributary streams, such as the Delta, Gerstle, Johnson, and Robertson rivers, dump large volumes of granular sediment into the Tanana River, causing the river floodplain to abruptly change from a meandering mode upstream from the river junctions to complexly braided and anastomosing downstream, where river bars are light toned on aerial photographs, indicating that they are composed primarily of permeable sand and gravel (Anderson, 1970; Dingman and others, 1971; Nelson, 1995).

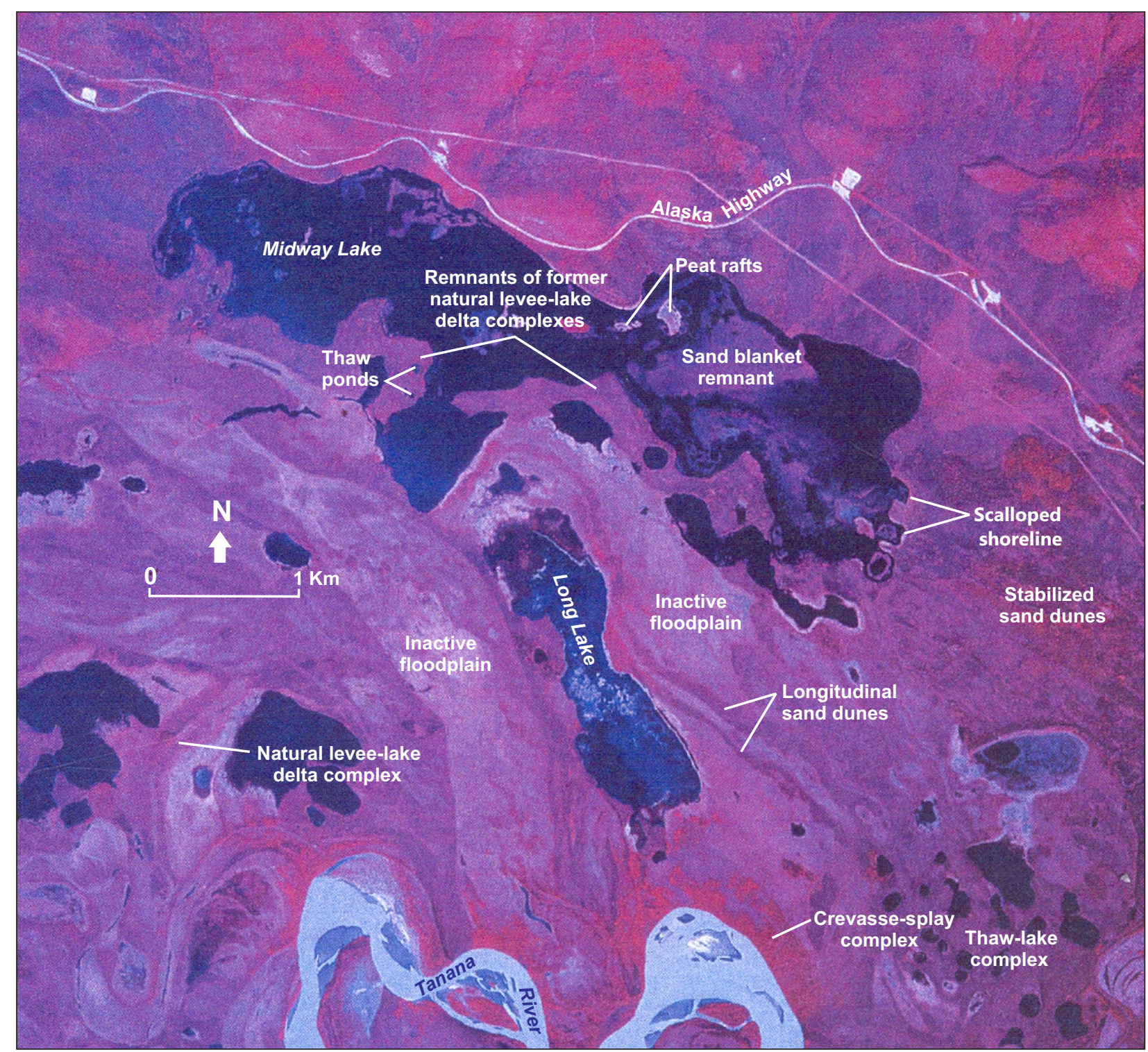

Figure 2. Vertical false-color infrared aerial photograph showing fluvial, eolian, and thermokarst features near Midway Lake, north-central Tanacross A-3 Quadrangle (Reger and others, 2012a, fig. 3). Thaw ponds and thaw lakes indicate that remnants of natural levee-lake delta complexes are fine grained and ice rich. A natural levee-lake delta complex divides lakes west of Long Lake. Scalloped southeastern shoreline of Midway Lake is evidence that stabilized and frozen sand dunes are locally ice rich or overlain by fine-grained, ice-rich, frozen sediments. Orientations of longitudinal sand dunes on inactive floodplain of Tanana River indicate depositing winds consistently blew from the northwest in this part of the upper Tanana River valley. Thaw-lake complex in southeastern corner of figure developed on fluvial terrace that predates inactive flood plain (Alaska High Altitude Photograph ALK 60 CIR 21-341, taken July 1978). 
Near the mouth of Sheep Creek upstream from the junction with the Robertson River, the Tanana River valley narrows significantly where the southern Yukon-Tanana Upland approaches to within $3 \mathrm{~km}$ of the northern flank of the eastern Alaska Range (sheet 3). Through this narrow, 31-km-long reach to the vicinity of Moon Lake, the Tanana River follows a meandering course, and the river floodplain is confined against the bedrock hills of the southern Yukon-Tanana Upland by outwash fans and colluvial-fluvial fans emanating from valleys in the eastern Alaska Range (Carrara, 2004a; Reger and others, 2011). Point bars and river bars are dark toned on aerial photographs, indicating that they are composed of saturated fine sand and silt.

From Moon Lake $-77 \mathrm{~km}$ upstream to the mouth of the Tok River where the river is again pinned against the nose of a bedrock ridge, the Tanana River flows around the toe of the broad Tok expansion fan through a meander belt that is up to $-5.6 \mathrm{~km}$ wide (sheets 3 and 4 ) (Carrara, 2004b, 2006; Reger and others, 2011). The crests of bedrock knobs surrounded by alluvium stand -60 to $>182$ $\mathrm{m}$ above the floodplain and the outer Tok fan. The inset, finer-grained, eastern part of the broad fan (termed the Tok River alluvial fan) was deposited during the Holocene by the meandering Tok River (Reger and others, 2011).

Upstream of the Tok alluvial fan, the Tanana Lowland separates the easternmost Alaska Range from the maturely dissected, gentle slopes and broad valleys of the southeasternmost Yukon-Tanana Upland (Wahrhaftig, 1965). Streams in the riverine lowland are typically bordered by well-defined meander belts featuring flood-derived crevasse-splay and natural-levee complexes associated with Holocene expansion fans and slackwater basins. Shallow lakes in slackwater basins are segmented by complexes of natural levees and lake deltas, and shorelines are locally scalloped by thermo-erosion of frozen sand dunes (fig. 2).

On the proximal fan of the Nabesna River, Richter (1976) identified five broad, radiating fingers of active granular floodplains and low fluvial terraces that separate slightly higher and older wedges of mixed fluvial and lacustrine deposits. To the east, the granular apron of the combined fans of Stuver Creek and the Chisana River spreads northeastward into scattered bedrock hills of the southeastern Yukon-Tanana Upland. North of these broad alluvial fans in the riverine lowland is an extensive complex of fluvial and lacustrine sediments bounded by and containing stabilized and reworked sand dunes in lowlands against and between rounded bedrock hills. Near the Canada border, the Scotty-Desper creeks lowland was impounded by the distal expansion of the Chisana River fan (sheet 6).

Today, strong winds seasonally blow along the axis of the Tanana Lowland corridor (Mitchell, 1956), deflate sand and silt from unvegetated stream bars, and carry them downwind to depositional sites in the lowland (Péwé, 1951, 1955). Extensive dune fields, now vegetated and stabilized, were deposited on outwash surfaces and river terraces (Kreig and Reger, 1982; Reger and others, 2008a, 2011, 2012a). During the Holocene, variable local winds deposited thick, sandy loess on moraines and bedrock near high-volume sources of silt and sand (Péwé and Reger, 1983a). Compositionally, loess along the Tanana River is made up of mineral grains of igneous and metamorphic rocks (Péwé, 1955; Muhs and others, 2003), and locally the carbonate content is significant (Péwé, 1968), providing the source of calcium carbonate rinds formed on the bottoms of clasts at the base of the loess and in Cca horizons in weathering profiles. Archeological investigations demonstrate that most loess near the Tanana River in the western corridor is latest Wisconsinan to Holocene in age (Hamilton and Goebel, 1999; Potter, 2005; Potter and others, 2008, 2011a, b, 2014; Holmes, 2011). However, much older loess and retransported silt mixed with lowland loess are preserved in the corridor southeast of Tok in the southern Yukon-Tanana Upland (Schaefer, 2002; Reger and others, 2012a).

\section{Eastern Alaska Range}

South of the Tanana Lowland and east of the Delta River valley in the eastern Alaska Range, the highest peaks reach elevations of $-3,050 \mathrm{~m}$, and there are large areas above $\sim 1,830 \mathrm{~m}$ elevation where ice caps and extensive valley glaciers developed during past cold climates and persist today. Mountain valleys and jagged, sharp, intervening bedrock ridges result from alpine glacial erosion. Mountain slopes are littered with the products of gravitydriven processes, including talus fans and aprons, rock glaciers, and slope-failure deposits (Foster and Holmes, 1965) (sheets 1-3). In higher parts of the corridor farther southeast, modern snowline is at $-1,670 \mathrm{~m}$ elevation (Reger and others, 2011).

A record of multiple glaciation is preserved in the major drainages of the eastern Alaska Range, including the Delta, Gerstle, Little Gerstle, Johnson, Robertson, and Tok rivers (Reger and others, 2008a, 2011). Moraines and associated outwash fans of late Pleistocene age are present in smaller alpine valleys of the eastern Alaska Range between the Robertson River valley and the TokTanacross lowland (Reger and others, 2011) (sheets 3 and 
4). During our field investigations, we did not observe evidence for maximum (late Pliocene-early Pleistocene) glacial extents and ice-marginal lakes previously mapped in the upper Tanana River drainage by Duk-Rodkin and others $(2002,2004)$.

During the penultimate (Delta) glaciation, high-level surfaces such as the Granite Mountain plateau and Macomb Plateau were the sites of ice caps from which outlet glaciers drained into surrounding lowlands (sheets 1 and 2). The Granite Mountain plateau, which has general elevations of 1,524 to $1,646 \mathrm{~m}$, supported an ice cap of Donnelly age, and former cirque glaciers that developed around the plateau margins left well-preserved, empty cirques, creating a distinctive biscuit-board topography (Lobeck, 1939). No ice cap developed during the last major glaciation on the lower Macomb Plateau, which has general elevations of 1,280 to $1,372 \mathrm{~m}$. Instead, ice-free surfaces were subject to intense freezing and thawing, and permafrost developed on the plateau. Small cirque glaciers, nourished by wind-drifted snow, reoccupied two older cirques along the northern margin of the Macomb Plateau (Reger and others, 2008a). Between Dry Creek and Chief Creek, the stream-dissected eastern extension of the Macomb Plateau rises between 244 and $549 \mathrm{~m}$ above and south of the Tanana River trough beyond the limit of late-Pleistocene glaciation (Reger and others, 2008a) (sheet 2). This granitic terrane is deeply weathered and dissected, and granitic tors stand high above ridge crests and upper slopes where the surrounding grus was differentially stripped by periglacial slope processes (fig. 3). Unglaciated dendritic tributary stream valleys in this area contain frozen fills of sandy grus wash mixed with lowland loess. Coarse fills in drainages entered by ice during past glaciations, such as Berry Creek, are composed of outwash related to moraines in upper valleys. Lower slopes of the steep northern flank of the dissected plateau are littered with aprons of blocky granitic rubble formed by downslope displacement of the frost-rived, coarsely jointed bedrock (Reger and others, 2008a).

Southwest of Tanacross airfield the coarse, piedmontapron diamictons on the lower northwest-trending, linear mountain front are tectonically deformed into conspicuous, arcuate, discontinuous growth-anticline ridges (Carver and others, 2010) (cover photo). Active thrust faulting there is a continuation of neotectonism associated with the Northern Foothills Fold and Thrust Belt (NFFTB) to the west along the northern flank of the Alaska Range (Bemis and Wallace, 2007; Carver and others, 2008a, b, 2010; Bemis and others, 2012)(sheets 1-4).

Foster (1970) suggested that the dissected alpine surface just south of the corridor between the Tok River valley and the 2,057-m summit of Mount Neuberger is a remnant of a warped preglacial erosion surface (fig. 4).

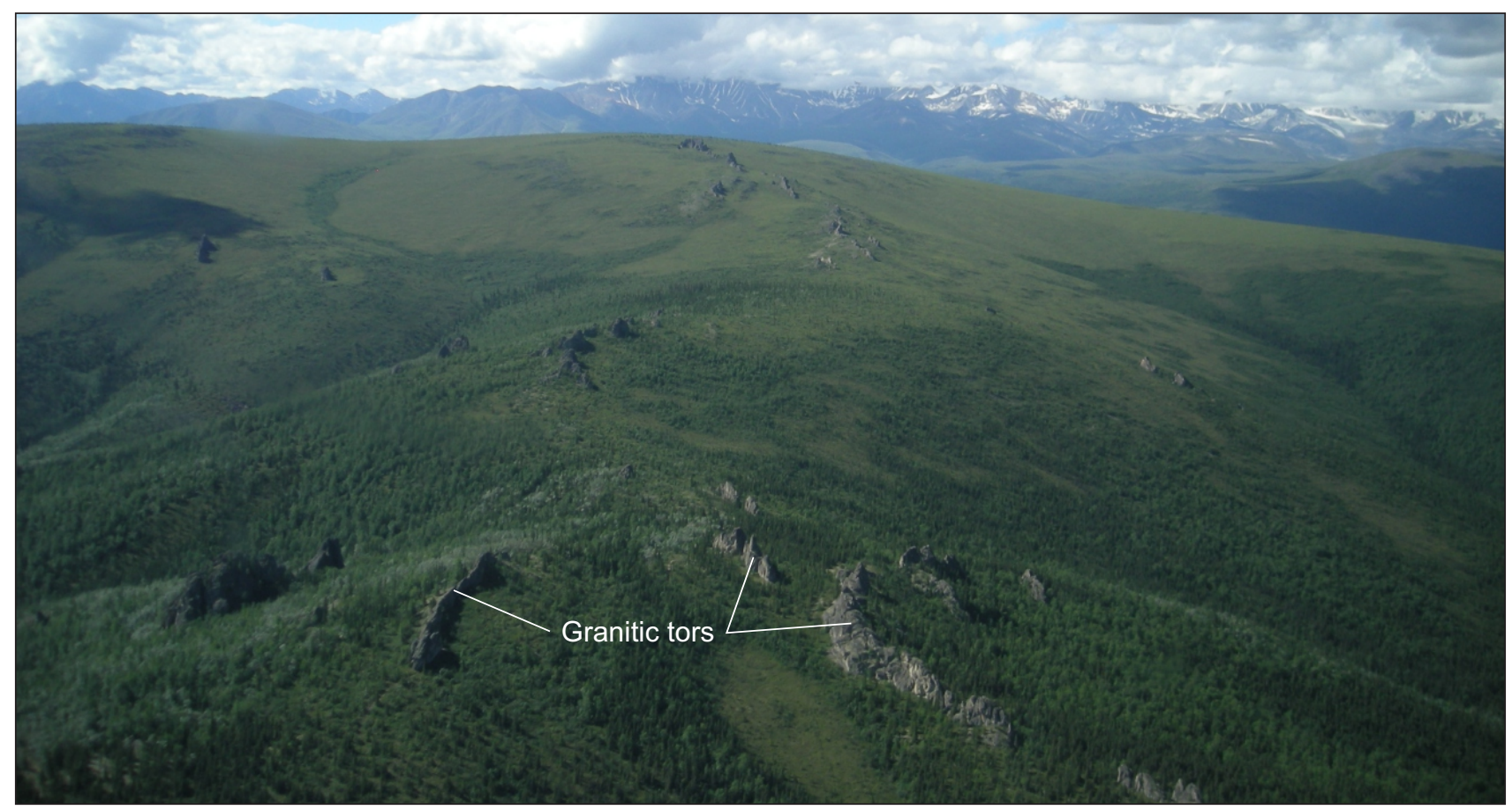

Figure 3. Aerial view southward of granitic tors in Knob Ridge area, central Mount Hayes C-1 Quadrangle (sheet 2) (Reger and others, 2008a, fig. 2). Photograph taken 7/13/2007. 


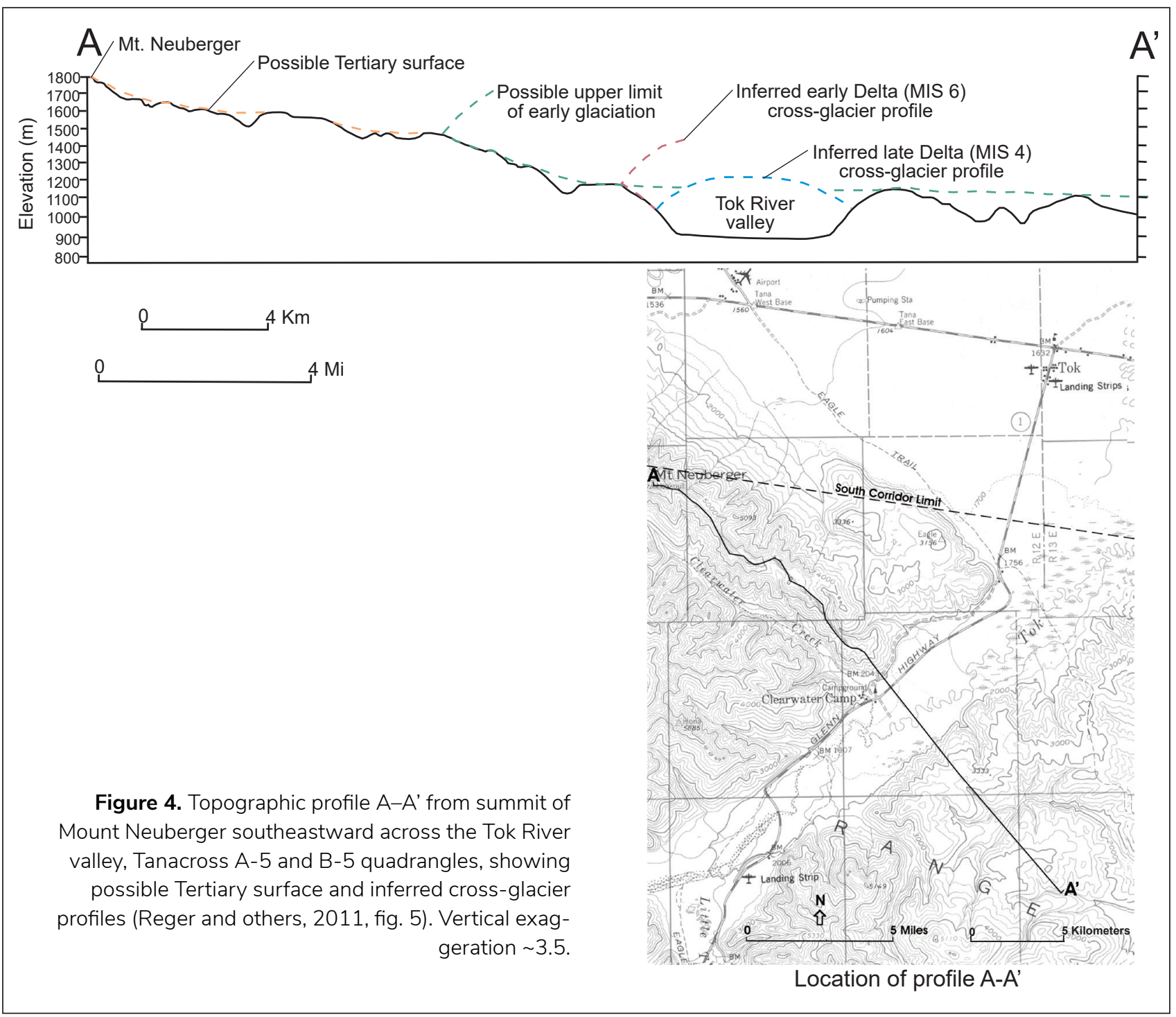

Dry slopes on the upland are discontinuously vegetated with Dryas mats, and moist slopes are well vegetated by a variety of moisture-tolerant alpine plants and exhibit gelifluction features. Bedrock tors along ridge crests and on upper side slopes demonstrate that differential stripping by periglacial slope processes has removed at least $5 \mathrm{~m}$ of the metamorphic bedrock. The steep, western portion of this upland surface could reflect $-152 \mathrm{~m}$ of original relief on a former erosion surface or could have resulted from faster uplift of the Alaska Range to the west. Toward the southeast, the slope of this surface is fairly uniform down to $-1,500$ m elevation, which could be the highest level reached by glaciation in the Tok River valley (fig. 4).

\section{Southern Yukon-Tanana Upland}

Southeast of the Alaska Highway bridge across the Tanana River east of Tok, the route of the Alaska Highway traverses the southern Yukon-Tanana Upland to the Canada border. In the southern upland, rounded bedrock hills reach elevations of 701 to $1,128 \mathrm{~m}$ above broad stream valleys with gently sloping walls and general floor elevations of 640 to $762 \mathrm{~m}$. Valley walls and floors of extensive, underfit, low-gradient, upper tributaries of northeast-flowing major streams, such as the Ladue River and the Dennison Fork of the extensive and entrenched Fortymile River network (Yeend, 1996), are covered by undifferentiated and retransported eolian sediments and slope colluvium. In these ancient, well-integrated drainages, short reaches through narrow canyons between broad basins hint at complex tectonic and drainage histories (Tempelman-Kluit, 1980; Bender and others, 2018). Many valleys have asymmetric cross profiles, perhaps in response to different rates of gelifluction on slopes with different aspects (French, 2007, p. 22). In contrast, short, relatively steep, south-flowing tributaries of the Tanana and Chisana rivers are much younger and are eroding headward into the upland, conditions that favor stream piracy. For example, Gardiner Creek displays a prominent 
elbow of capture at the corridor limit in the central $\mathrm{Na}-$ besna D-1 Quadrangle where Gardiner Creek intersected and beheaded the former longer course of Scotty Creek, another Chisana River tributary (Reger and others, 2012a) (fig. 5). Just downstream from the elbow of capture, Gardiner Creek passes through a distinctive, short canyon across a sand-blanketed bedrock ridge (sheet 5 ). This short canyon could be evidence of local deformation that raised the underlying bedrock ridge, causing Gardiner Creek to cut downward through the sediment cover, implying fairly recent local uplift and an antecedent origin for this reach (Douglass and others, 2009). Downstream from the bedrock canyon, Gardiner Creek is underfit.

During the penultimate and last major glaciations, strong katabatic winds swept downslope across outwash fans and

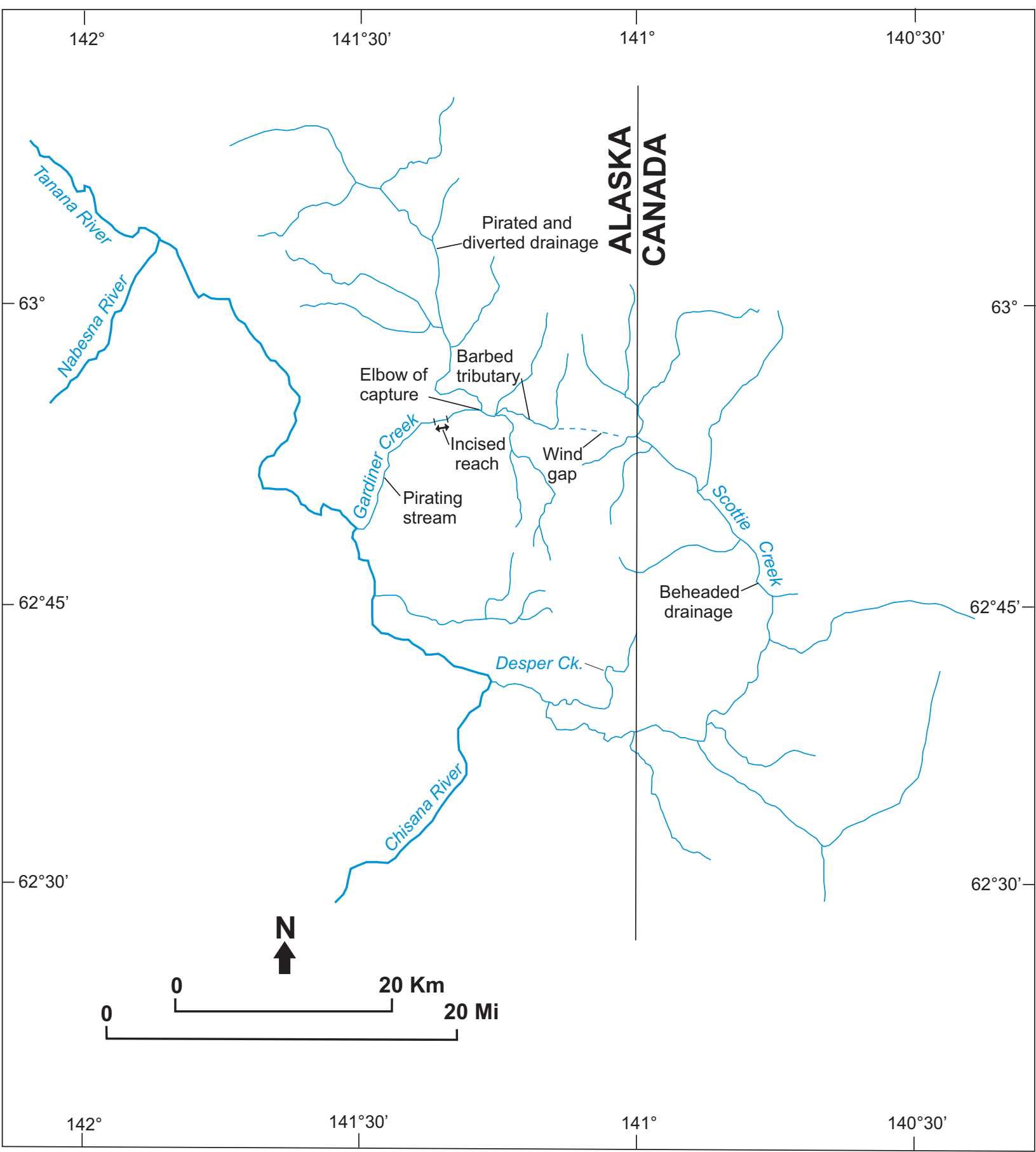

Figure 5. Physiographic features demonstrating piracy by Gardiner Creek of headwaters of much longer former course of Scotty Creek (Reger and others, 2012a, fig. 2). 
aprons at the mouths of major tributary valleys along the northern flank of the eastern Alaska Range, entraining and transporting sand and silt into nearby riverine lowlands and into the southern Yukon-Tanana Upland (Thorson and Bender, 1985; Lea and Waythomas, 1990; Muhs and others, 2003; Muhs and Budahn, 2006; Reger and others, 2008a, 2011, 2012a). Surprisingly, little loess of late Pleistocene age has been recognized across central Alaska north of the Alaska Range, probably because strong katabatic winds in glaciated valleys and lack of forest vegetation during the last major glaciation did not permit deposition and preservation of large volumes of loess, even near source areas (Thorson and Bender, 1985; Muhs and others, 2003; Busacca and others, 2004). A contributing factor is the extensive retransportation of eolian sediments to form widespread, frozen, fine-grained valley fills (Kreig and Reger, 1982).

The Tetlin Junction dune field is northeast of the Tok fan and separated from it by the Tanana River (sheet 4).
The position of the Tetlin Junction dune field relative to the Tok fan indicates that the eolian sands there were deposited by strong katabatic winds sweeping northeastward out of the Tok River valley and across the Tok fan (Reger and others, 2011). Wildfires in the dune field have periodically destroyed the surface vegetation and locally reactivated the dunes (fig. 6).

\section{GLACIAL DEPOSITS AND HISTORY}

Surface evidence of several glaciations as old as late Tertiary is preserved in the western Alaska Highway corridor (Péwé and Reger, 1983b; Reger and Péwé, 2002; Reger and others, 2008a, 2011). Differences in relative extents and morphological and weathering properties are the basis for identifying deposits of these advances. The most useful soil properties for differentiating glacial deposits in the field are solum depth; color of B horizon; frequency, color, and thickness of silt-clay skins; intensity

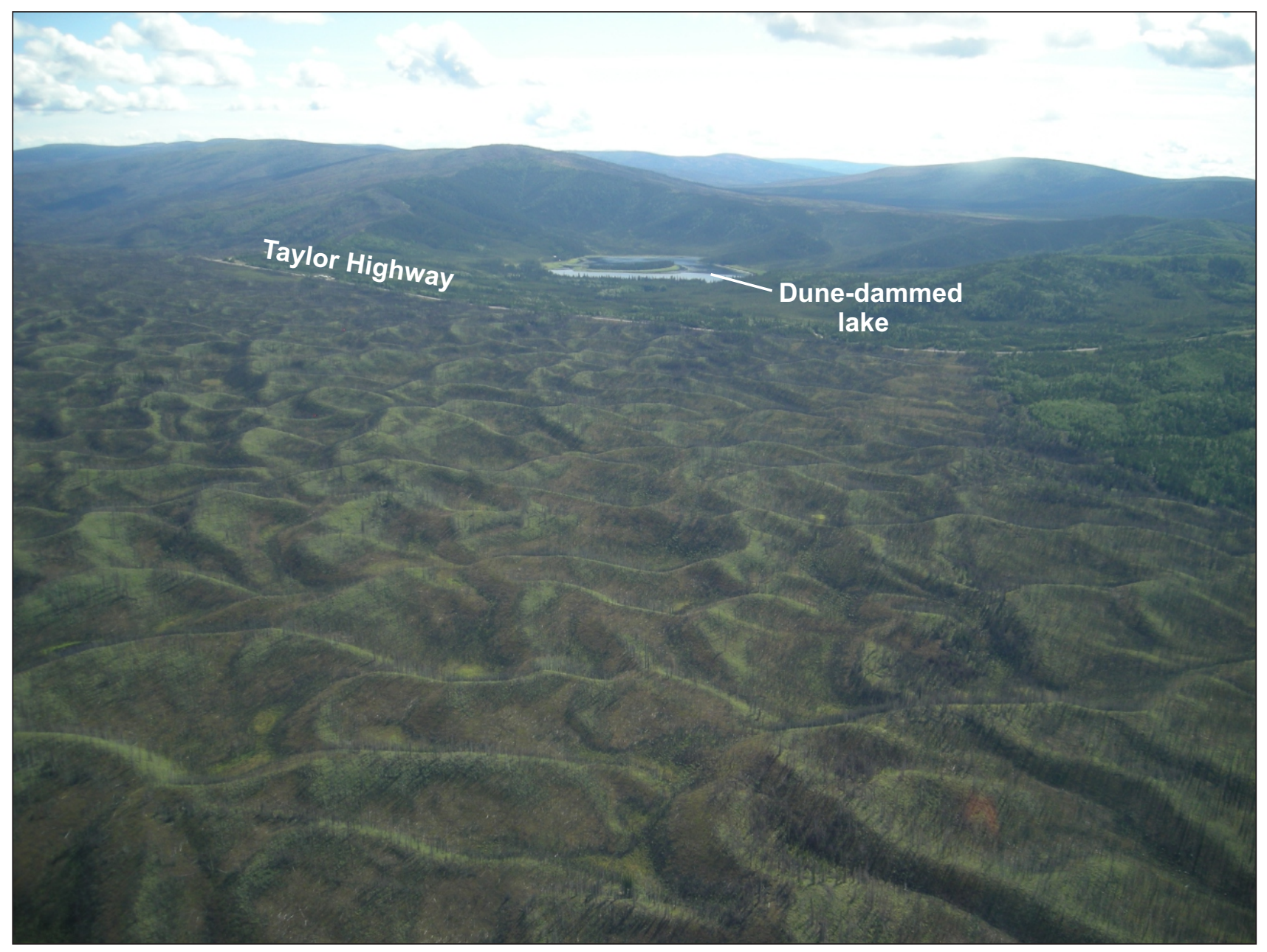

Figure 6. Aerial view northeastward of lake impounded behind parabolic sand dunes in recent burn near the Taylor Highway north of Tetlin Junction, east-central Tanacross B-4 Quadrangle (Reger and others, 2011, fig. 4). Photograph taken 6/12/2007. 
of soil alterations; and presence of cryogenic features (Tarnocai and others, 1985). With caution, the presence and degree of development of ventifacts can also be used to identify deposits of late Pleistocene glaciations in the corridor (Péwé and Holmes, 1964; Péwé and Reger, 1983a).

\section{Late Tertiary glaciation}

Carter (1980) described numerous angular to rounded boulders as large as $2.1 \mathrm{~m}$ across in tilted, massive to crudely bedded, glacigenic conglomerate beds in the upper Nenana Gravel at $-880 \mathrm{~m}$ elevation along a bedrock ridge on the steep northeastern front of the Granite Mountain block west of the Gerstle River (fig. 7). Boulders in the conglomerates are fresh to "rotten" and include lithologies that are alien to the Gerstle River drainage today. The large sizes, shapes, and variable compositions of the boulders could indicate that conglomerate beds are glacial or jökulhlaup gravels. The stratigraphic context indicates that this early glaciation occurred during the Pliocene Epoch. Late Pliocene movements on the Granite Mountain fault resulted in the tilting of the beds (Carver and others, 2008a).

\section{Early glaciations}

One or more glaciations could be included in the sparsely documented Darling Creek glaciation, which was named by Péwé (1975a) for patches of drift on a high-level bedrock surface above the Delta River valley and assigned a pre-Illinoian age. Possible correlative glaciations include pre-Healy glaciations in the Nenana River valley to the west (Wahrhaftig, 1958; Thorson, 1986), the Charley River glaciation in the Yukon-Tanana Upland to the north, and pre-Reid glaciations in the Yukon Territory to the east (table 2).

In the western corridor, there is physiographic and soil evidence for one or more early glaciations. The walls and floors of cirques and valleys assigned to the earliest glacial advance(s) in the northern corner of the Granite Mountain upland are greatly modified by frost weathering, accumulation of extensive colluvial deposits, and postglacial stream erosion. Till of pre-Delta age in the Cockscomb, Arrow, and Hajdukovich creeks drainages is deeply weathered and is

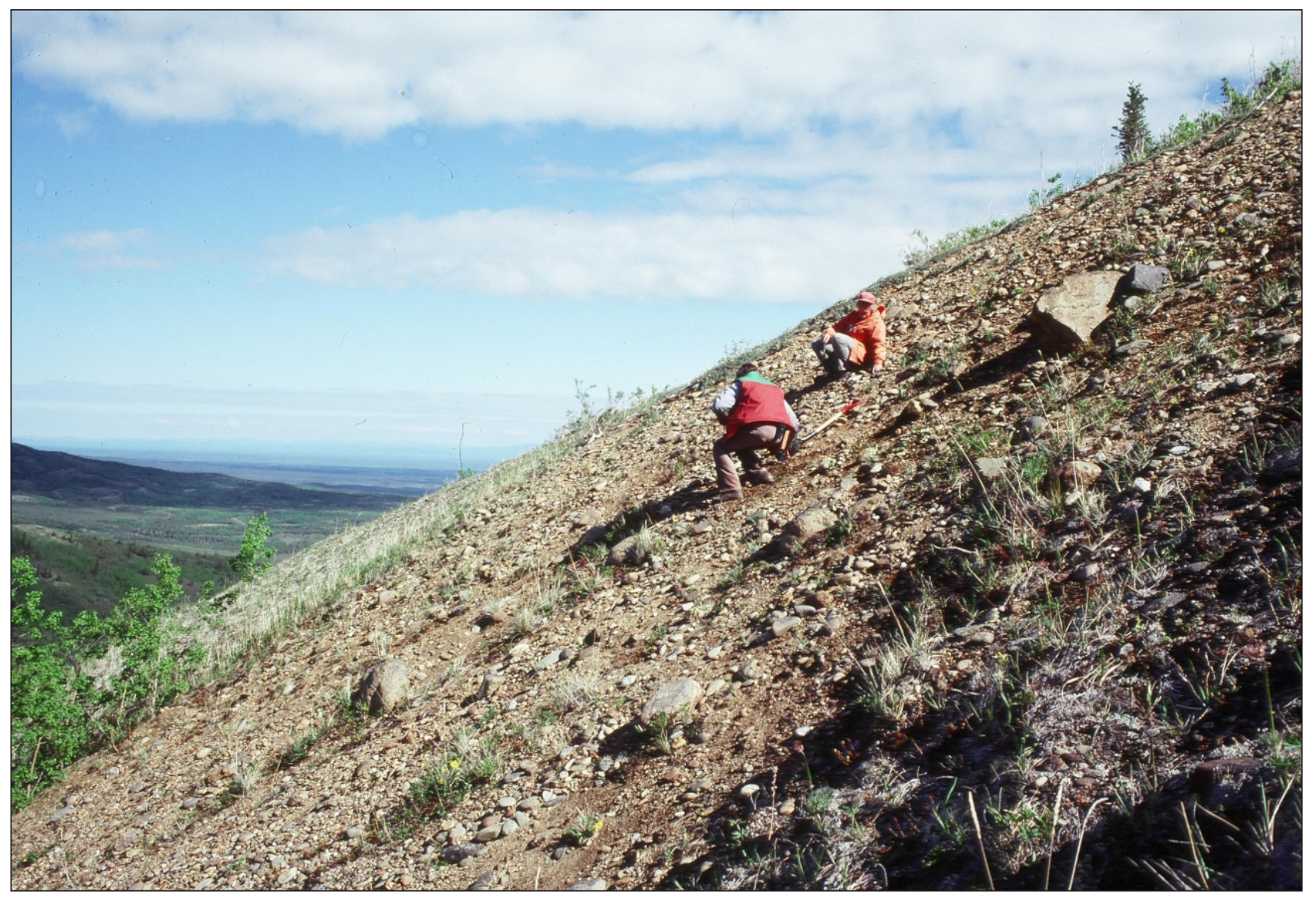

Figure 7. Tilted glacial or jökulhlaup deposits in upper Nenana Gravel of Pliocene age at $~ 880$ m elevation, northeastern Mount Hayes C-3 Quadrangle (Reger and others, 2008a, fig. 3). Photograph taken June 1978. 
Table 2. Comparison of Quaternary glacial chronologies in the eastern Alaska Range, Yukon-Tanana Upland, and western Yukon Territory.

\begin{tabular}{|c|c|c|c|}
\hline $\begin{array}{c}\text { Marine } \\
\text { Isotope Stage }^{a}\end{array}$ & $\begin{array}{c}\text { Eastern Alaska Range } \\
\text { Delta River valley eastward }\end{array}$ & Yukon-Tanana Upland & $\begin{array}{c}\text { Cordilleran Ice Sheet } \\
\text { western Yukon Territory }\end{array}$ \\
\hline & $\begin{array}{l}\text { Péwé and Holmes (1964) } \\
\text { Holmes (1965) } \\
\text { Holmes and Péwé (1965) } \\
\text { Holmes and Foster (1968) } \\
\text { Péwé and Reger (1983a) } \\
\text { Duk-Rodkin and others (2004) } \\
\text { Hamilton (unpub. data, 1982) }\end{array}$ & $\begin{array}{l}\text { Weber (1986) } \\
\text { Duk-Rodkin and others (2004) } \\
\text { Briner and others (2005) }\end{array}$ & $\begin{array}{l}\text { Smith and others (1986) } \\
\text { Hughes (1989) } \\
\text { Tarnocai (1989) } \\
\text { Tarnocai and others (1985) } \\
\text { Tarnocai and Schweger (1991) }\end{array}$ \\
\hline \multirow{2}{*}{$\begin{array}{c}1 \\
(0-11.0 \mathrm{ka})\end{array}$} & Holocene glaciation $^{\text {bc }}$ & Unknown ${ }^{d}$ & Holocene glaciation $^{\mathrm{b}}$ \\
\hline & Post-Donnelly soil & Immature soil formation & Stewart soil \\
\hline $\begin{array}{c}2 \\
(11.0-25.0 \mathrm{ka})\end{array}$ & Donnelly glaciation & $\begin{array}{l}\text { Ramshorn advances } \\
\text { Salcha glaciation }\end{array}$ & McConnell glaciation \\
\hline $\begin{array}{c}3 \\
(25.0-\sim 35.0 \mathrm{ka}\end{array}$ & Post-Delta paleosol & Variable soil formation & Diversion Creek paleosol \\
\hline $\begin{array}{c}4 \text { and } 6 \\
(\sim 35.0-\sim 190.0 \mathrm{ka})\end{array}$ & Delta glaciation ${ }^{e, f}$ & Eagle glaciation & Reid glaciation $^{\mathrm{e}, \mathrm{f}}$ \\
\hline \multirow{2}{*}{$\begin{array}{c}\text { Pre-6 } \\
(>\sim 190.0 \mathrm{ka})\end{array}$} & Pre-Delta paleosol(s) ${ }^{g}$ & Deep soil formation & Wounded Moose paleosols \\
\hline & Darling Creek glaciation(s) & Charley River glaciation & Pre-Reid glaciations \\
\hline
\end{tabular}

\footnotetext{
${ }^{a}$ MIS ages from Railsback and others (2015) modified by evidence accumulated during this investigation.

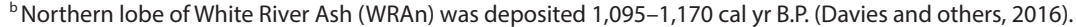

' Unit G/tephra F of Hayes tephra was deposited 3,910-4,205 cal yr B.P. (Davies and others, 2016).

d Previously named Ramshorn I and II advances (Weber, 1986), but later dated as late Wisconsinan by Briner and others (2005).

e Sheep Creek tephra (SCt-) CC, C, K, and A, which were previously thought to date 190 ka (Berger and others, 1996; Schaefer, 2002) are now thought to date 80 ka, based on optically stimulated luminescence (OSL) ages, and postdate the Reid and Delta glaciations (Westgate and others, 2008). SCt-F, which is stratigraphically beneath the Old Crow tephra (OCt) in the Fairbanks area, is still thought to date 200 ka and predate the Delta glaciation (Westgate and others, 2008).

${ }^{\mathrm{f}}$ For many years, Old Crow tephra (OC) was dated at $~ 140$ ka (Preece and others, 1999; Schaefer, 2002) but was initially recalculated to be $131 \pm 11$ ka by Péwé and others (2009). More recently, comparison of OCt and a newly redated glass fission-track standard indicates that the OCt could have a mean age of $124 \pm 10 \mathrm{ka}$ (Preece and others, 2011).

${ }^{9}$ Includes the Gerstle River paleosol of Duk-Rodkin and others (2004).
}

preserved as discontinuous patches surrounding numerous low bedrock knobs that are arranged roughly in a lobate pattern beyond terminal moraines assigned to the younger Delta glaciation (Reger and others, 2008a) (sheet 1). An isolated remnant of pre-Delta moraine is also preserved as a cluster of subangular to subrounded granitic erratics up to $65 \mathrm{~m}$ above the highest level of the early Delta (MIS 6) terminal moraine at the mouth of Dry Creek valley (Reger and others, 2008a) (sheet 2).

On the upland surface between upper Dry Creek and upper Berry Creek, possible pre-Delta glacial deposits lack morainal morphology and form discontinuous surface lags in small valleys and on upper slopes of rounded granitic ridges outside the limits of Delta moraines (Reger and others, 2008a) (sheet 2). No original glacier-scoured bedrock surfaces are preserved there, but a reddish-brown paleosol that is associated with this surface is exposed in the east wall of upper Dry Creek valley and could represent a pre-
Delta paleosol (table 2) ${ }^{4}$. At the head of the east fork of Dry Creek beyond the Delta moraine, the well-dissected valley floor is broadly $\mathrm{U}$-shaped in cross profile, in contrast to the $\mathrm{V}$-shaped cross profiles of other tributary valleys cut into the weathered granitic terrane there; we attribute this more open cross profile to ice scouring prior to the Delta glaciation.

During their reconnaissance survey of east-central Alaska, Duk-Rodkin and others (2004) identified paleosols at two localities in the western corridor that they correlated with the suite of Wounded Moose paleosols of Pliocene to middle Pleistocene age in the western Yukon Territory (table 2). One locality is the paleosol exposed in the east wall of upper Dry Creek valley. A second locality is on the west wall of Gerstle River valley, where a mature, rubified weathering profile $>1 \mathrm{~m}$ thick is present in extremely weathered till at 695 m elevation. The DukRodkin party sampled the paleosol for paleomagnetic 
signature, which showed normal polarity, and tentatively assigned it to the Gauss Chron (2.6 to 2.9 Ma), the Olduvai Subchron (1.77 to $1.95 \mathrm{Ma}$ ), or perhaps the Jaramillo Chron (0.99 to $1.07 \mathrm{Ma}$ ) on the basis of $>90$ percent weathered clasts and the deep profile development.

Farther east, evidence of early glaciation is questionable. Duk-Rodkin and others $(2002,2004)$ identified Pliocene-early Pleistocene glacial erratics in the upland northwest of the Tok River valley south of Tok and proposed that a thin weathering profile associated with the erratics is possibly early to middle Pleistocene in age. Their paleomagnetic sample has a normal paleomagnetic signature, which they related to the Bruhnes Epoch because the erratics are fairly well preserved. At two localities on the same upland surface, Foster (1970) mapped patches of gravel that she believed to be Tertiary in age. Our later visits to those sites revealed no evidence of glaciation, and we concluded that the thin, discontinuous lag of white quartz, quartzite, schist, and gneiss pebbles and cobbles that was present was likely produced by residual weathering of the local metamorphic bedrock and colluvial reworking of high-level, possibly Tertiary, stream gravels.

Even less certain is the claim by Duk-Rodkin and others $(2002,2004)$ that fairly well preserved granitic, volcanic, and chert erratics are present northeast of Tok at the margin of the southern Yukon-Tanana Upland. They attributed those erratics to a pre-middle Pleistocene glaciation from the eastern Alaska Range that advanced down the Tok River valley and filled the Tok-Tanacross lowland to at least $\sim 674 \mathrm{~m}$ elevation. If true, this occurrence would be very unusual for the Tanana River valley, where several workers have searched in vain for evidence of glaciation north of the Tanana River. A survey of the area by Paul Carrara (written commun., 2008) revealed only the presence of spheroidal boulders resulting from the weathering of the local granitic bedrock. Our work confirms his finding (fig. 8). During a traverse along the nearby old road to Tok, we encountered patches of gravel containing subangular to subrounded pebbles

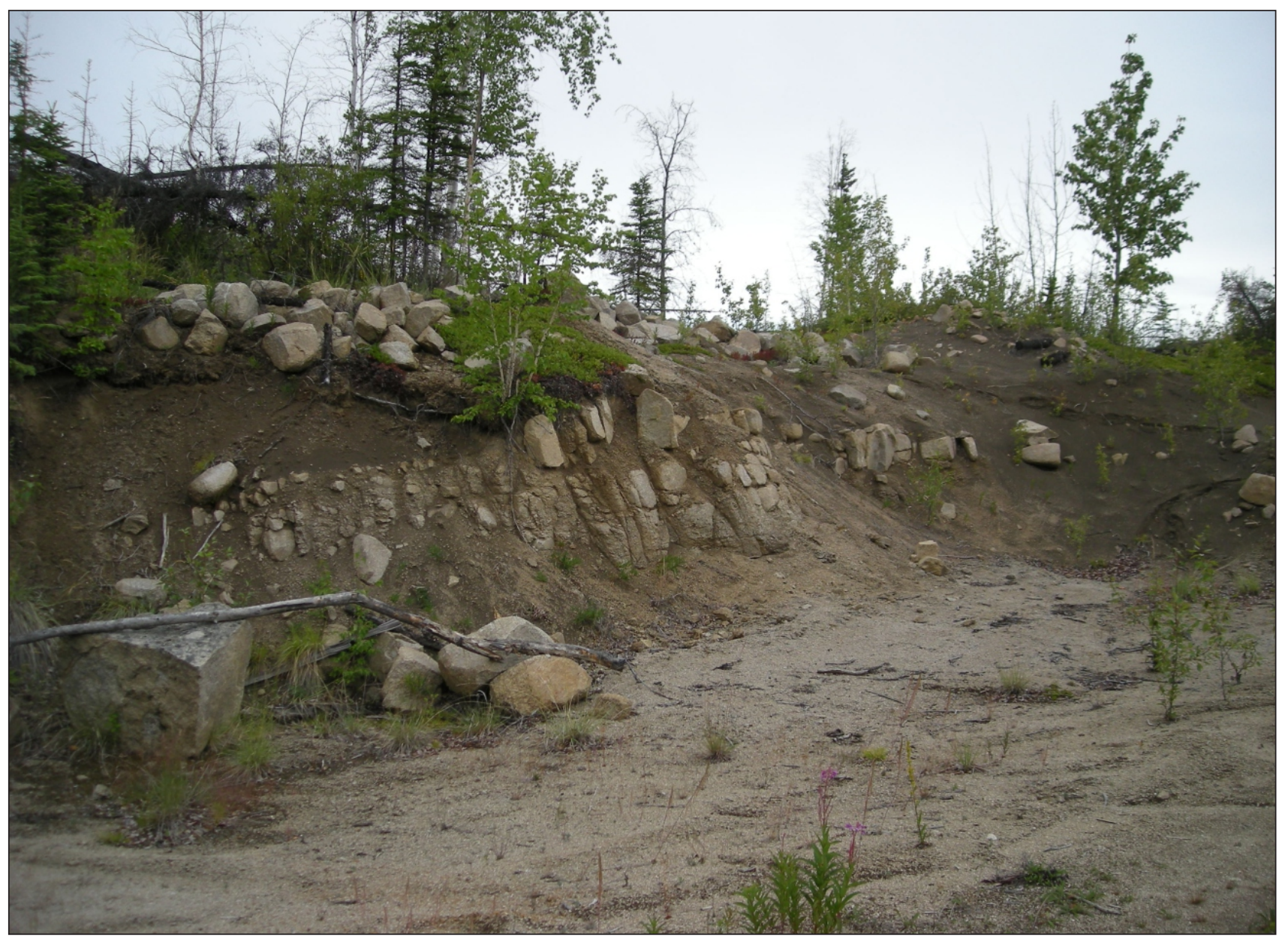

Figure 8. View northeastward of subrounded to rounded granitic core stones and weathered granitic bedrock in quarry near mouth of Porcupine Creek, east-central Tanacross B-4 Quadrangle (Reger and others, 2011, fig. 6). Photograph taken 7/23/2008. 
and cobbles of fine-grained amygdaloidal volcanics and granitics, a small greenstone boulder, and a distinctive, subrounded vesicular-volcanic cobble that clearly came from the Wrangell Mountains and is a key component of flood gravels in the Tok River drainage (Hubbard and Reger, 2010b). Except for the granitic clasts, all of these clasts are different than the local granitic bedrock. We initially interpreted the exotic gravels as possible run-up deposits from major outburst floods because they are $-36 \mathrm{~m}$ above the modern Tanana River floodplain and are directly in line with the Tok River valley to the southwest (Reger and others, 2011). However, we found no other exotic gravels along the old Tok road in that area, raising the likelihood that the gravels were hauled to the site from gravel sources on the Tok expansion fan and used as road bedding.

Evidence for maximum late Pliocene-early Pleistocene glacial extents and ice-marginal lakes that were mapped by Duk-Rodkin and others $(2002,2004)$ in the upper Tanana River valley could not be verified during our field investigations. However, we identified an undated deposit of glacial drift in an Alaska Highway roadcut $-4.3 \mathrm{~km}$ east of the Canada border near the Little John archeological site (Easton and others, 2009, 2011). Inside Alaska west of the Canada border, Duk-Rodkin and others (2002) placed the middle Pleistocene ice limit in the Chisana River drainage in the southeastern corner of the corridor, $-8 \mathrm{~km}$ downvalley from the limit of the last major (Jatahmund Lake $=$ Donnelly) glaciation mapped by Richter (1976), who recognized only a small patch of penultimate (Black Hills = Delta) drift in the drainage. According to Duk-Rodkin and others (2002), ice of the penultimate glaciation blocked the lower Scotty Creek drainage and impounded a moderate-sized meltwater lake in the lowland, which today contains numerous thaw lakes. They also placed ice of the penultimate glaciation against the bedrock ridge north of the Chisana River west of Scotty Creek and mapped a meltwater lake in the Chisana River lowland that extended westward $87 \mathrm{~km}$ to the vicinity of Tetlin Junction. However, we found no evidence of glaciation in Alaska west of the Canada border north of the Chisana or Tanana rivers, or surface features related to a large meltwater lake. Hemenway (1994) drilled five boreholes to depths of 27 to $35 \mathrm{~m}$ at the crossing of Scotty Creek near the Alaska Highway and penetrated up to $31 \mathrm{~m}$ of silt and sandy silt with thin interbeds of fine-grained organic material, which could represent bottom sediments in an impounded meltwater lake. However, the lack of other evidence for a meltwa- ter lake argues against a former lake. Instead, we believe that the fine-grained fill in the Scotty and Mirror Creek lowlands represents a slackwater sequence resulting from local stream flooding and the distal growth of the large Chisana River fan.

\section{Delta glaciation Features}

In the Delta Junction area, the type terminal moraine of the Delta glaciation consists of a relatively high and narrow, arcuate, outer morainal ridge and a relatively broad and low, inner arcuate moraine, implying a two-stage event (Péwé and Holmes, 1964; Reger and Péwé, 2002) (sheet 1). These moraines were built by an unusually large tongue of ice that accumulated on the southern side of the central Alaska Range and flowed through the range down the Delta River valley (Péwé and Reger, 1983a). Stones in the type moraines and associated outwash are composed of bedrock types in the Delta River valley to the south. Topographic relief of Delta-age moraines is locally more subdued than local relief of the younger nearby Donnelly-type terminal moraine, and there are fewer kettles and kettle lakes per unit area on Delta moraines than on Donnelly moraines (Péwé and Reger, 1983a, table 3). Proximal outwash of Delta age extends from the outer Delta terminal moraine northward toward the Tanana River and is abruptly terminated by the Clearwater Lake escarpment (fig. 9). High-volume springs emerging along the base of the escarpment supply ground water for Clearwater Lake and Clearwater Creek, which are important fish-overwintering habitats. The ultimate source of those waters is unknown, but Williams (1970, p. 44) proposed that it is the deep aquifer, confined beneath till of Delta age and supplied by infiltration of water from the Delta River southwest of Fort Greely.

Clasts in exposed sites on moraines and proximal outwash of Delta age are commonly shaped and polished into classic ventifacts (Reger and Péwé, 2002). On nonuniform lithologies with variable hardness, shallow, vortex-etched pits and short grooves are well developed, and resistant inclusions and mineral crystals stand up to $4 \mathrm{~mm}$ in relief. Bottoms and lower surfaces of ventifacts on Delta-age surfaces typically bear calcareous coatings. These distinctive objects are also typical components of pebbly eolian-sand casts of former ice wedges, which are common on landforms of Delta age and reach widths of $\sim 1 \mathrm{~m}$.

During the Delta glaciation, an extensive ice cap developed between $\sim 1,402$ and $\sim 1,707$ m elevation on 
the northern Granite Mountain upland. This ice-accumulation center supplied considerable ice to the drainages of Granite, Rhoads, and Sawmill creeks, and the outlet glaciers in those drainages were much more extensive than coeval glaciers in small, snow-impoverished valleys at -975 m elevation along the mountain front (Reger and others, 2008a). Overlapping relations demonstrate that advances were not simultaneous in different drainages. For example, the terminal moraine and outwash of the Jarvis-Granite creeks lobe overlaps the earlier east lateral moraine of the Delta River lobe (Reger and others, 2008a). Farther east, cross-cutting moraines demonstrate that ice of Delta age advanced out of the Little Gerstle River valley after the Delta advance in the larger Gerstle River valley (Hamilton, unpub. data).

The lack of a terminal moraine and associated outwash of Delta age for the Johnson River lobe is anomalous, and no glacial erratics or deposits have been found nearby on densely forested bedrock ridges north of the Tanana River (sheet 2). However, the log of a water well drilled in 2001 for the nearby Dry Creek community (sheet 2, locality A) indicates that till of Delta age is present beneath $-30 \mathrm{~m}$ of proximal outwash of Donnelly age (Steve Squires, unpub. data). We speculate that the lack of a terminal moraine of Delta age and the lack of erratics north of the Tanana River could be the result of their removal by periodic massive flooding down the Tanana River (described in a later section).

The Macomb Plateau-Horn Mountain upland supported a broad ice cap during the Delta glaciation (Holmes and Foster, 1968) and likely received ice from higher parts of the Alaska Range to the south. A few large granitic erratics are widely scattered across the Macomb Plateau, but no morainal form is preserved there and slopes are smooth and rounded (sheet 2). At least $2 \mathrm{~m}$ of perennially frozen, ice-rich organic silt with some sand and scattered pebbles, cobbles, and boulders on the plateau surface are the result of reworking of Delta drift, primarily by gelifluction (Reger and Solie, 2008b) (fig. 10). On streamlined, ice-scoured bedrock knobs at the head of Dry Creek near the northern edge of the plateau, large, angular blocks of granitic bedrock were displaced upward as much as $\sim 1 \mathrm{~m}$ after the Delta glaciation by the growth of ice in subhorizontal bedrock joints

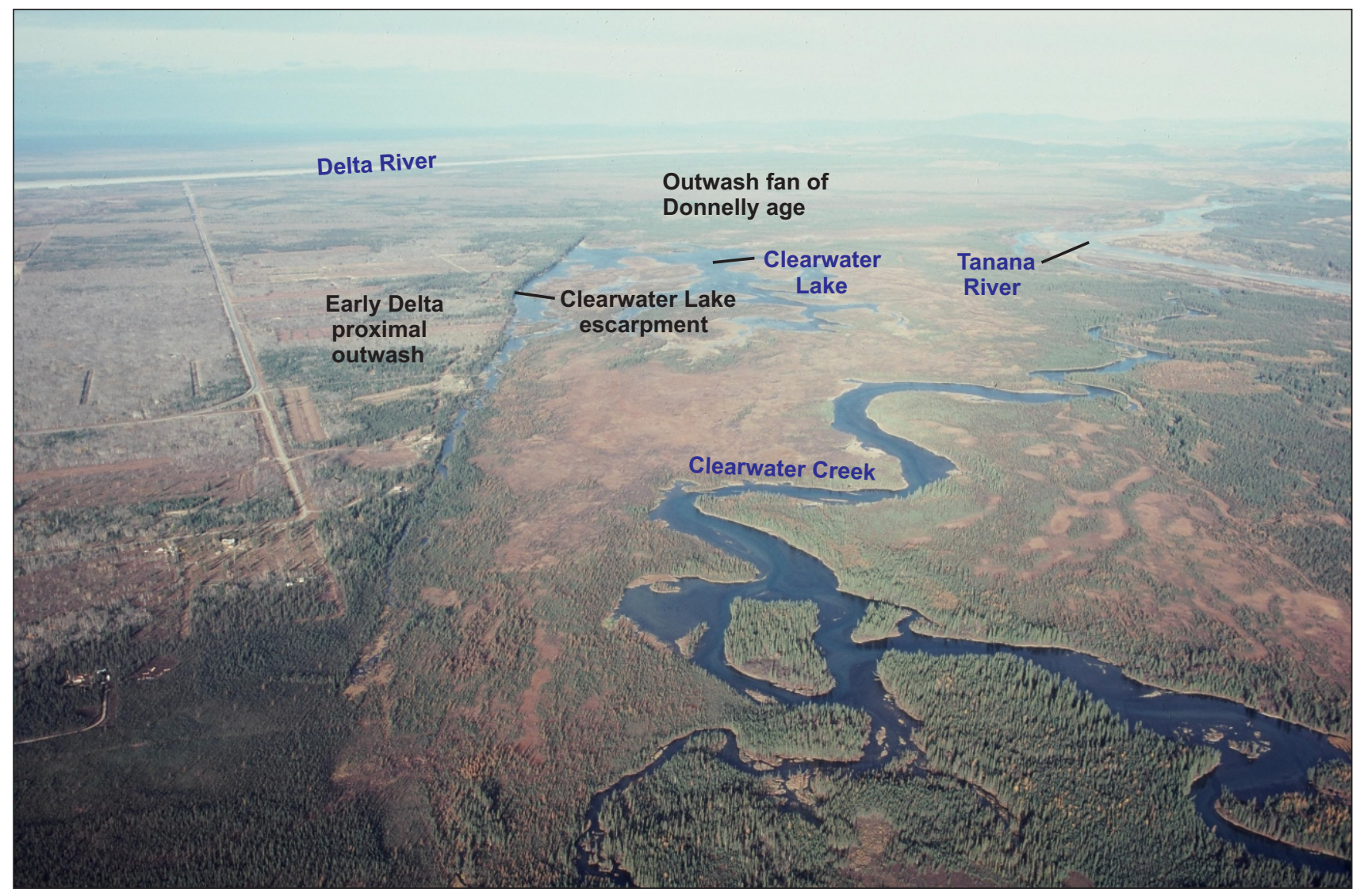

Figure 9. Aerial view westward of Clearwater Lake escarpment truncating proximal outwash of the early Delta (MIS 6) glaciation, east-central Big Delta A-4 Quadrangle (Reger and others, 2008a, fig. 4). Photograph taken September 1976. 


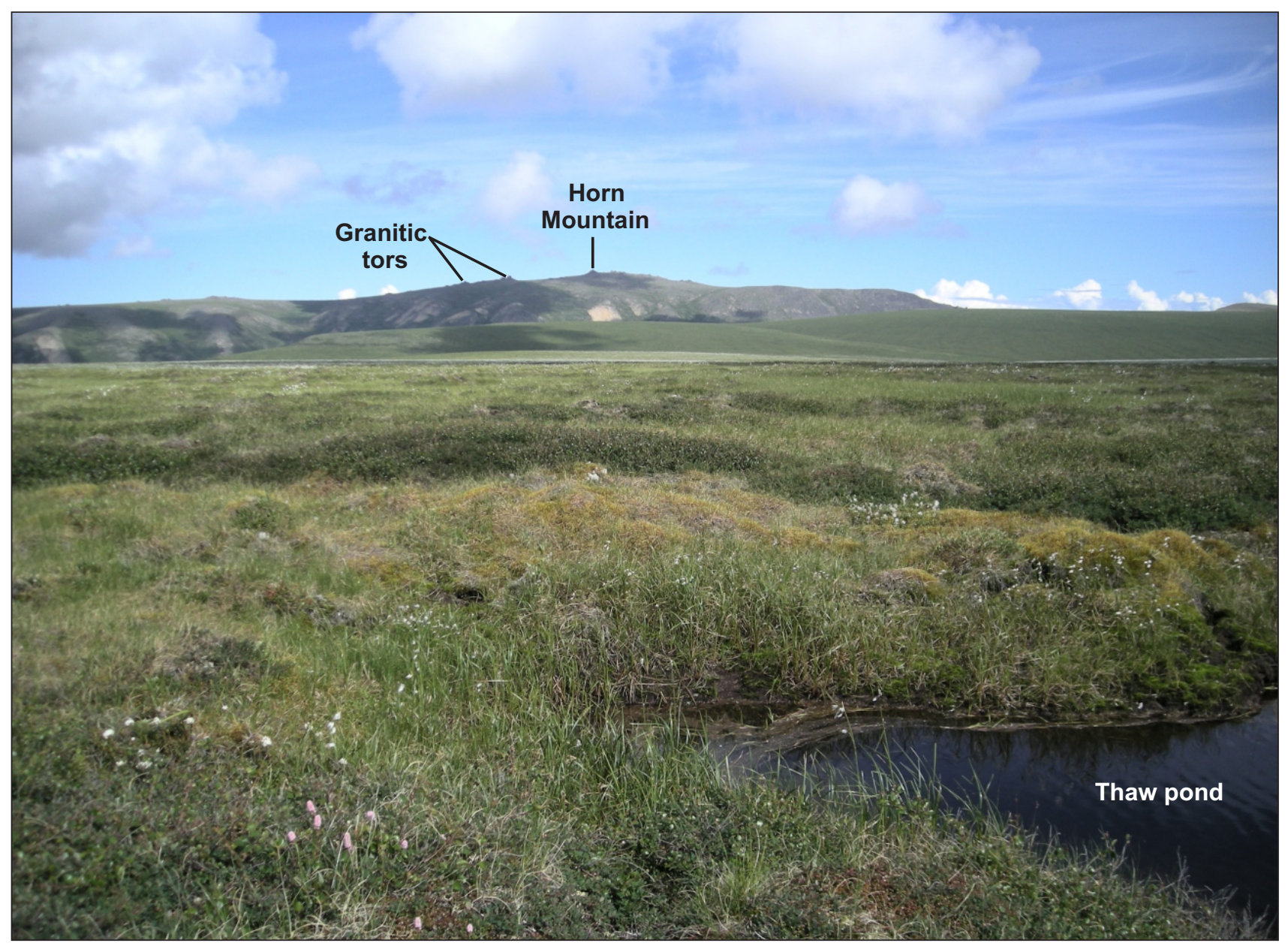

Figure 10. View northward of alpine tundra at 1,325 m elevation on Macomb Plateau, central Mount Hayes C-2 Quadrangle. Granitic tors along skyline near Horn Mountain are residual bedrock eminences left after differential stripping by nearsurface periglacial slope processes (Reger and others, 2008a, fig. 6). Photograph taken 7/9/2007.

(Yardley, 1951), disrupting the former ice-polished surface (fig. 11). An outlet glacier extended down the valley of Dry Creek, where a pair of end moraines was emplaced. Delta ice entered upper Sears and upper Berry creeks and apparently fed into the Johnson River-Little Gerstle River system (Reger and others, 2008a) (sheet 2).

An obvious blunt end moraine of late Delta age at the mouth of upper Dry Creek valley is $30-60 \mathrm{~m}$ thick, and has fairly high relief in contrast to other moraines of Delta age (fig. 12; sheet 2). A test pit in this moraine exposed a pre-Donnelly inceptisol profile that is $>78 \mathrm{~cm}$ deep and in which thick silt-clay caps are present on the upper surfaces of till clasts to at least that depth. Formerly, this moraine was assigned to the Donnelly glaciation by Holmes and Foster (1968), who postulated that the source was a plateau glacier of Donnelly age on the Macomb Plateau at the head of the valley. However, we found no evidence for a plateau glacier of Donnelly age on the Macomb Plateau. Instead, post-Delta talus forms are widespread and well developed on the lower walls of upper Dry Creek valley, including large debris-flow fans at the mouths of tributary valleys in the west valley wall. A stubby, blocky rock glacier has developed at the base of the west valley wall at the head of the valley. The abrupt, square terminus of the upper Dry Creek moraine could indicate that the moraine has been offset by faulting. An escarpment extends along the base of the bedrock ridge east of the end moraine. However, no escarpment is present across the base of the end moraine and none offsets the slope west of the moraine. Thus, local evidence for faulting is ambiguous, and the origin of the escarpment is uncertain.

Mapping of moraines in valleys cut into the northern margin of Macomb Plateau near Horn Mountain demonstrates that valley glaciers developed there during both Delta and Donnelly glaciations, probably in response to winter winds sweeping snow from Macomb 


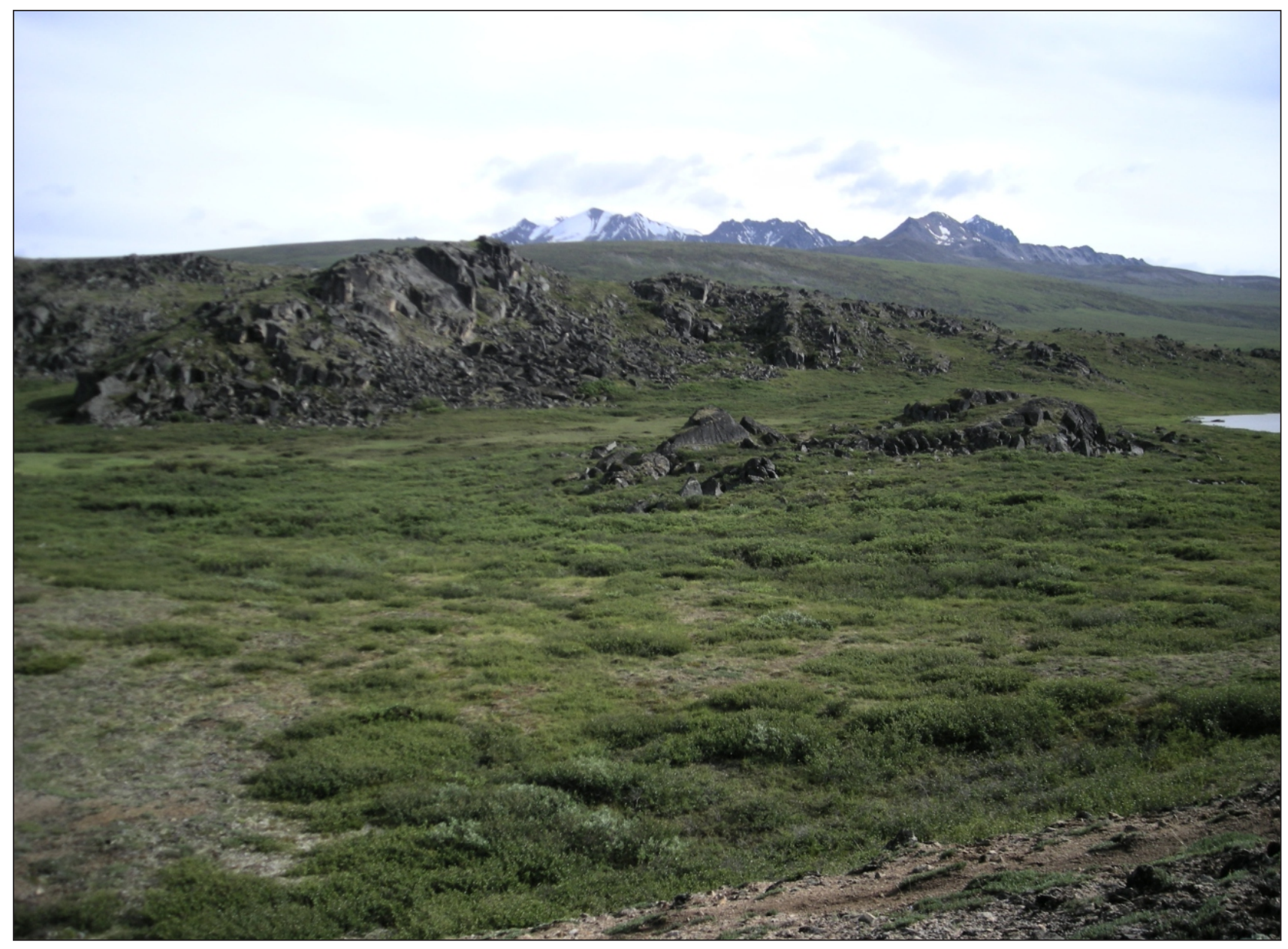

Figure 11. View southeastward of granitic knobs scoured by glacial ice during Delta glaciation of Macomb Plateau at head of Dry Creek, east-central Mount Hayes C-2 Quadrangle (Reger and others, 2008a, fig. 7). Irregular knobs were formed by periglacial frost-jacking of joint blocks in granitic bedrock during later Donnelly glaciation. Photograph taken 7/9/2007.

Plateau into leeward valleys (Reger and others, 2008a) (sheet 2). Valleys that were glaciated only during Delta time have headwalls and floors that are extensively modified by the accumulation of colluvium, including massive, multi-generational debris flows, and associated outwash that is now deeply notched by postglacial stream erosion (fig. 13). In contrast, valleys that were reoccupied during the Donnelly glaciation retain steep headwalls with extensive, bold rock outcrops, valley walls are notched by shallow snow-avalanche couloirs, and colluvium is generally limited to lower slopes. The nature of the colluvium in these valleys is a function of the properties of the bedrock upslope. Coarsely jointed granitic bedrock produces blocky colluvium, and schists and layered quartzites yield fine-textured debris.

Remnants of the terminal moraine of the Robertson River glacial advance of Delta age are preserved outside the massive Donnelly terminal moraine in the Bear Creek drainage and between the terminal moraine of Donnelly age and the bedrock hills enclosing Jan Lake (Reger and others, 2011, fig. 10) (sheets 2 and 3). These features and the lateral moraine of Delta age outside and above the terminal moraine of Donnelly age south of the Robertson River indicate that Delta ice was thicker and more extensive there than ice of the last major glaciation.

Faceted spurs as high as $-670 \mathrm{~m}$ elevation on the western face of Tower Bluffs could be evidence that the Robertson River glacier was as thick as $-170 \mathrm{~m}$ against that rock wall during the Delta glaciation (fig. 14). However, we lack conclusive evidence that the Robertson River glacier actually blocked the Tanana River during the late Pleistocene, as suggested by Duk-Rodkin and others (2004). Several 30-m-deep boreholes drilled for bridge foundations along the Alaska Highway east of the Robertson River junction failed to encounter obvious lake deposits that would record downstream damming of the Tanana River (Hemenway 


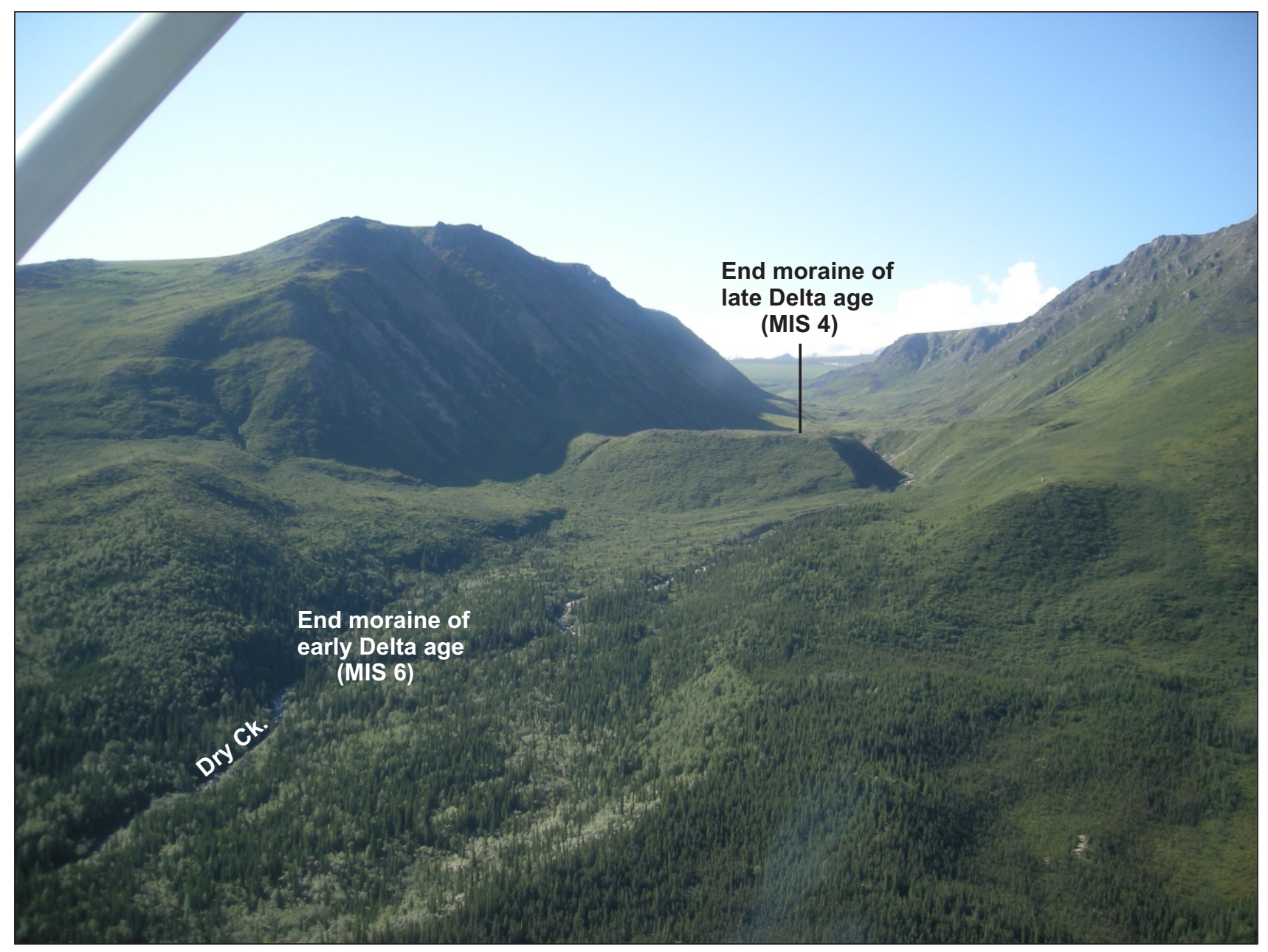

Figure 12. Aerial view southeastward of early (MIS 6) and late (MIS 4) end moraines of Delta glaciation, upper Dry Creek valley, east-central Mount Hayes C-2 Quadrangle (Reger and others, 2008a, fig. 8). Photograph taken 7/13/2007.

and Weaver, 1983). Several failures in Tower Bluffs could have resulted from removal of lateral support (debuttressing) when glacial ice withdrew from the cliff (Cossart and others, 2008) or from undercutting of Tower Bluffs by the Tanana River, or both.

Delta-age lateral moraines, lobate terminal moraines, and associated outwash fans are related to alpine valleys in the eastern Alaska Range between the Robertson River and the Tok-Tanacross basin (sheets 3 and 4). We found no evidence that late Pleistocene advances from any of the alpine glaciers upriver from Robertson River dammed the Tanana River in the Sheep-Yerrick creeks reach. Along the mountain front southwest of the Tanacross airfield, outwash fans of the penultimate and last major glaciations extend from end moraines downslope between dissected ridges of tectonically deformed colluvial-fluvial deposits (Reger and others, 2011) (sheets 3 and 4). Those discontinuous ridges, which were previously mapped as moraines of Delta age by Foster (1970), as granitic and intermediate intrusive bedrock by Carter and Galloway (1978), and as bedrock by Carrara (2004a), are actually the spectacular consequences of active thrust faulting (Carver and others, 2010) (cover photo).

The Tok River valley just south of the Alaska Highway corridor is clearly inset into a dissected upland surface of possible Tertiary age (fig. 4). Changes in the slopes of the walls of the Tok River valley at $\sim 1,140 \mathrm{~m}$ and $\sim 1,010 \mathrm{~m}$ elevation along profile A-A' could indicate the upper limits of the early and late phases of the Delta glaciation. Foster (1970) mapped discontinuous lateral moraines along both sides of the valley almost to the range front, and she assigned them a pre-Delta age. On the basis of comparable weathering characteristics, DukRodkin and others (2004) correlated the post-moraine soil with the Diversion Creek soil, which postdates the Reid glaciation in the Yukon Territory, and correlated the moraines in the Tok River valley with the Delta glaciation to the west and with the Black Hills glaciation (Fernald, 


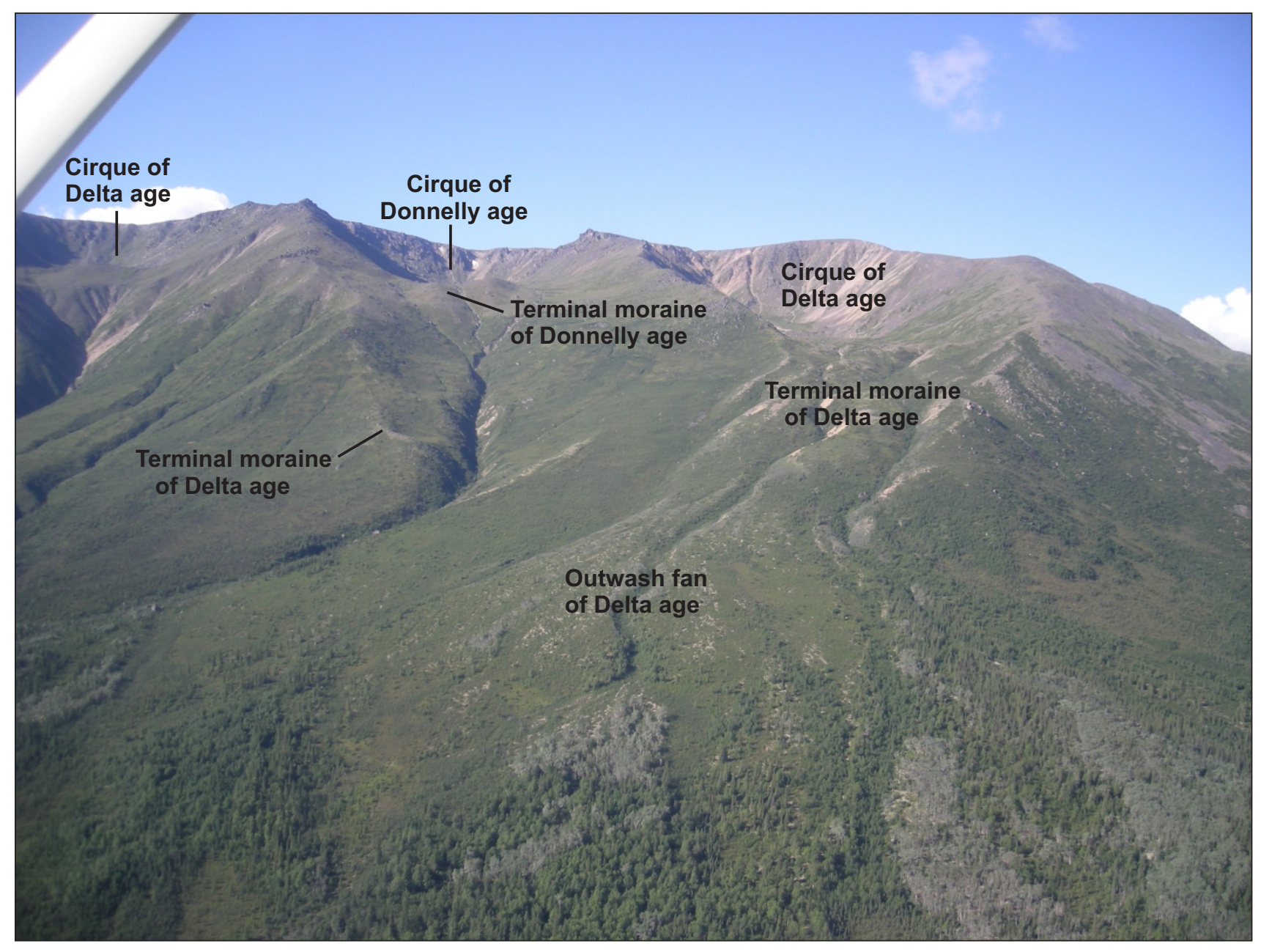

Figure 13. Cirques of Delta and Donnelly glaciations cut into northern margin of Macomb Plateau in the vicinity of Horn Mountain, central Mount Hayes C-2 Quadrangle (Reger and others, 2008a, fig. 9). Photograph taken 7/13/2007.

1965) to the east. We mapped a lateral moraine with Delta affinities to within $4.8 \mathrm{~km}$ west of the southern limit of the Alaska Highway corridor along the lower northwest wall of the lower Tok River valley.

\section{Correlation}

Typically, moraines and related landforms in the corridor are correlated by comparing surface expressions and weathering criteria. Moraines of Delta age have greater extent, lower relief, and have been more modified by surface processes than moraines of the Donnelly glaciation (Péwé and Reger, 1983a, table 3). In general, soils in the upper Tanana River valley are inceptisols produced by weak to moderate chemical weathering compared to areas such as south-central Alaska, where there is greater precipitation and spodosols result (Muhs and others, 2000, 2001, 2003). Holmes (1965, p. H10) and Holmes and Foster (1968, p. 28) reported that depths of iron-oxide staining in tills of Delta age in the corridor exceed $3 \mathrm{~m}$. In related outwash gravel, clasts are iron-oxide stained to depths of $1.1 \mathrm{~m}$ and disintegrated rock fragments are present to depths of $>3.6 \mathrm{~m}$. In hand-dug test pits on Delta-age moraines, we documented inceptisols as deep as $>1.1 \mathrm{~m}$ and silt caps up to $7.6 \mathrm{~mm}$ thick to depths of $>80 \mathrm{~cm}$ (Reger and others, 2008a, 2011), and tentatively correlate the post-Delta paleosol with the Diversion Creek paleosol in the Yukon Territory (table 2).

Inspections of soil profiles on landforms of Delta age indicate that post-Delta profiles are thicker than postDonnelly profiles developed on landforms of Donnelly age, but can have $\mathrm{B}$ horizons that are roughly equivalent in thickness and color to B horizons in post-Donnelly profiles. This could be due to periodic deflation of the soils, particularly where the B horizons are limited to the loess cover. However, downward displacement of silts and clays in post-Delta profiles has progressed to a degree that silt-clay caps are thicker than those in soil profiles of postDonnelly age, and silts and clays locally encase pebbles and cobbles in hardpan (Bt) horizons. Bw horizons in 


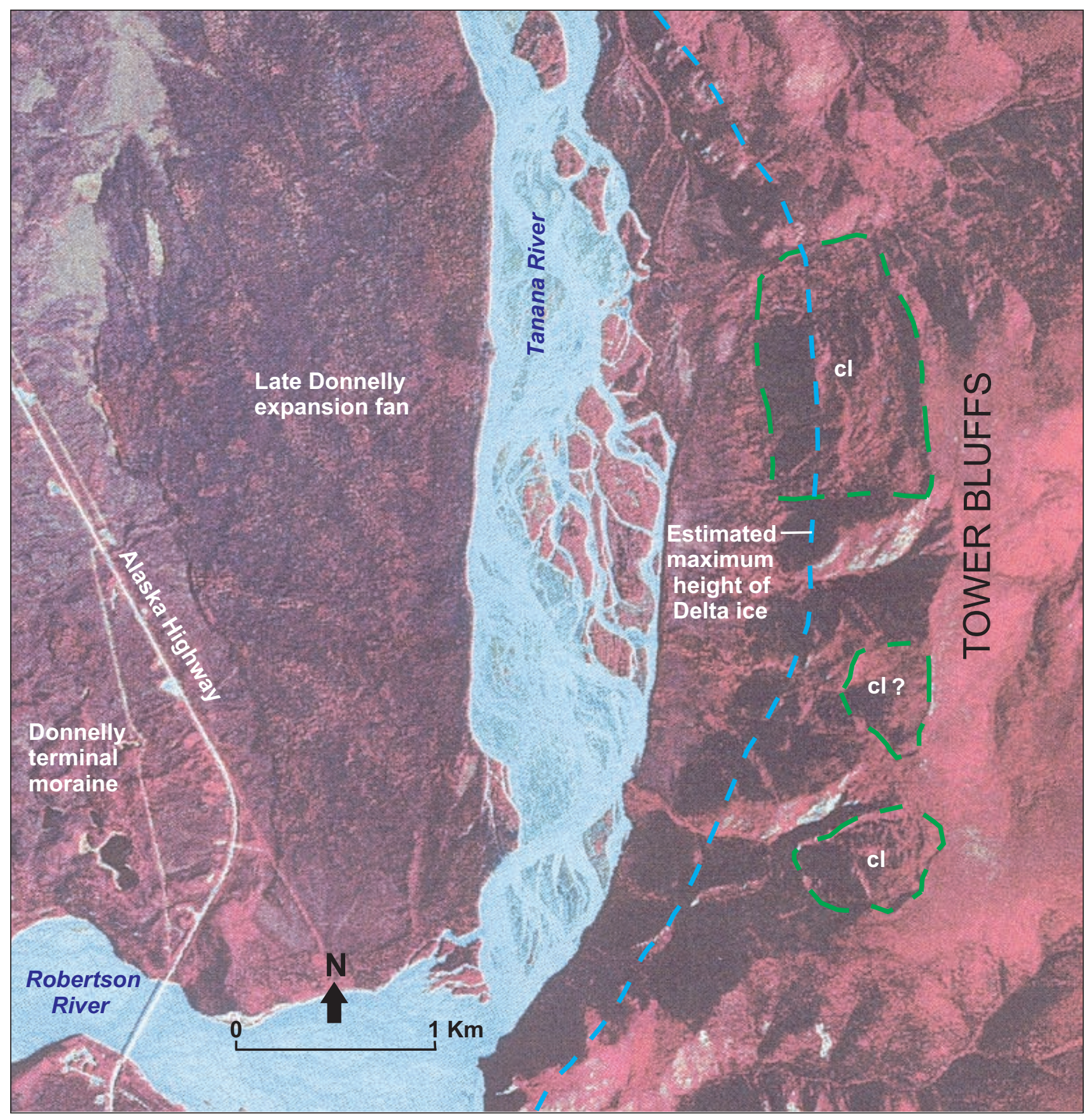

Figure 14. Vertical false-color infrared aerial photograph showing estimated maximum height of glacial ice against Tower Bluffs during Delta glaciation (dashed blue line) and failures (cl) in granitic bedrock (dashed green lines), Tanacross B-6 and C-6 quadrangles (Reger and others, 2011, fig. 9) (Alaska High Altitude Photograph ALK 60 CIR 8485, taken August 1980).

post-Delta soil profiles generally have an olive-brown (2.5Y5/4) color. Where there have been frequent wildfires, loess color ranges from pinkish gray $(7.5 \mathrm{YR} 6 / 2)$ to red (2.5R4/6), imparting a pinkish color to Delta drift sheets (Péwé and Reger, 1983a).

\section{Age}

The age of the Delta glaciation has long been controversial (Reger and others, 2008a). Because the glaciation occurred prior to the oldest ages obtainable by radiocarbon dating, other methods have been used to date that event. Initially, progress was based on relations between Delta moraines or outwash features and tephras in Alaska and the Yukon Territory (Westgate and others, 2001). Begét and Keskinen (2003) reported the Old Crow tephra (OCt) stratigraphically overlies alluvium of a terrace they attributed to the early Delta glaciation near Moose Creek 
southeast of Fairbanks, providing a minimum age for the Delta glaciation, and correlated it with marine isotopestage 6 (MIS 6). However, the age of the extensive OCt is estimated to range from $110 \pm 32 \mathrm{ka}$ (MIS 5d) $)^{5}$ to $160 \pm$ 30 ka B.P. (MIS 6c) (Berger and others, 1996; Péwé and others, 1997, 2009; Preece and others, 1999, 2011; Muhs and others, 2003), and recently it was revised to $124 \pm 10$ ka (MIS 5e) by Preece and others (2011). Complicating the dating of the Old Crow tephra and raising questions about the reliability of earlier glass fission-track ages and stratigraphic interpretations, Burgess and others (2019) proposed that eruption of the Old Crow tephra occurred $202,900 \pm 9,500 \mathrm{yr}$ ago, based on the mean crystallization ages of 8 youngest zircon crystals in the tephra. Nonetheless, analyses of plant and insect remains on the surface preserved beneath the OCt at the Palisades along the Yukon River and fossil remains in associated sediments indicate that the OCt was deposited late in MIS 6 time (Matheus and others, 2003), and we only tentatively support correlation with MIS 6 until Quaternary stratigraphy can be reconciled.

The maximum age of the Delta glaciation is provided by the Sheep Creek (SCt) tephra, which is stratigraphically $-3 \mathrm{~m}$ beneath the OCt in the upper Eva Creek section near Fairbanks (Preece and others, 1999). Partial- and total-bleach thermoluminescence dating of loess above and below tephra SCt-F in the Fairbanks area initially established its age there at $190 \pm 20 \mathrm{ka}$ (Berger and others, 1996), generally conceded to predate the Delta glaciation. However, this complex tephra includes several younger layers. A distinctive, white, glassy distal tephra (SCt-CC) was reworked in upper alluvium attributed to the Delta glaciation in the Canyon Creek section (Weber and others, 1981; Begét and Keskinen, 2003), where Hamilton and Bischoff (1984) provided uranium-series ages for bones apparently closely associated with the SCt-CC and concluded that it is $-72-89 \mathrm{ka}$ in age. Optically stimulated luminescence (OSL) dating of tephras SCt-C, SCt K, and SCt-A in the Yukon establishes their ages as $-80 \mathrm{ka}$ and their source as Mount Drum in the Wrangell Mountains (Westgate and others, 2008).

Although questions remain about the reliability of estimates for variable depths of snow covers through the Holocene, the effects of erosion by blowing snow on exposed boulder surfaces, and the effects of frost action on pebble collections (including multiple cycles of exposure and reburial), the results of recent cosmogenic-exposure dating seem to be providing consistent and reasonable age estimates, and the ages of many landforms that could not otherwise be dated are being assessed by this evolving technique. The most recent estimates of morainal ages in the Yukon-Tanana Upland, the Alaska Range, and the Yukon are the result of cosmogenic-exposure dating.

Recent investigations in the Yukon Territory and east-central Alaska provide stable-isotope and cosmogenic evidence that an early Wisconsin (MIS 4) glaciation occurred there (Briner and others, 2005; Lacelle and others, 2007; Ward and others, 2007). Briner and others (2005) collected four samples for cosmogenic-exposure (CE) age determination from boulders on the terminal moraine of the Eagle glaciation in the valley of Ramshorn Creek in the Yukon-Tanana Upland, where Weber (1986) assigned the Eagle advance to the early Wisconsin glaciation. Exposure ages, which are uncorrected for erosion, range from $25.1 \pm 1.0$ to $61.4 \pm 3.9$ ka without obvious outliers, which is typical of pre-late Wisconsin moraines, supporting assignment of the Eagle advance to the early Wisconsin (MIS 4) glaciation. In the Nenana River valley, Dortch and others (2010) reported a minimum stabilization age for the Healy moraines of $54.6 \pm 3.5 \mathrm{ka}$, and in the Swift River valley of the western Alaska Range, Briner and others (2005) dated stabilization of Farewell I moraines with four ${ }^{10} \mathrm{Be}$ ages between 58 and $52.5 \pm$ $5.6 \mathrm{ka}$, confirming their MIS 4 affiliation.

To evaluate the age of the younger pulse of the Delta glaciation in the type area, Young and others (2007) made five collections of 25 to 30 quartzose pebbles from the type Delta medial moraine near Donnelly Dome south of the map area. CE dating of exposed boulders was not conducted. An early Wisconsin (MIS 4) age of $53.5 \pm$ $11.0 \mathrm{ka}$ was obtained for those samples after eliminating a $24.7 \pm 0.6 \mathrm{ka}$ outlier. Matmon and others (2010) collected 15 samples for ${ }^{10} \mathrm{Be}$ dating from the younger, inner moraine of Delta age in the vicinity of Donnelly Dome, including samples from six boulders and two single large clasts, and seven gravel samples. Although there is considerable scatter in their results, the largest mode (40-70 ka) indicates that a readvance of the Delta River valley lobe to the inner end moraine likely occurred during the MIS 4 stade, as eight of 11 samples in the Delta group are of that age $(41.5 \pm 4.5 \mathrm{ka}$ to $70.8 \pm 7.8 \mathrm{ka})$. Post-depositional processes that likely affected the surface stabilization of the Delta moraine near Donnelly Dome during the MIS 3 interstade are represented by three of 11 samples $(25.7 \pm 2.8 \mathrm{ka}$ to $28.9 \pm 3.28 \mathrm{ka})$. The remaining four samples, which are anomalously young $(12.4 \pm 1.4 \mathrm{ka}$ to $18.4 \pm 2.0 \mathrm{ka}$ ), likely represent processes acting on the surface and near-surface of the inner Delta moraine during intense periglacial conditions of the Donnelly glaciation. 
Double moraines in the type area of the Delta glaciation and in Dry Creek valley provide evidence that the Delta glaciation was a two-stage event in the Alaska Highway corridor, as it was in the Nenana River valley (Thorson, 1986; Dortch and others, 2010). Clearly, the outer terminal moraine in the vicinity of Delta Junction predates the inner (MIS 4) end moraine near Donnelly Dome, and relations with the younger OCt tentatively indicate that the early Delta advance of the Delta River lobe occurred during MIS 6.

\section{Donnelly glaciation}

\section{Features}

The type terminal moraine of the Donnelly glaciation was deposited by the Delta River lobe west of Donnelly Dome (Péwé and Holmes, 1964) and did not extend as far down-valley as the Delta moraines (sheet 1 ). In the type area, the depths of weathering profiles range from 30 to $85 \mathrm{~cm}$, and the content of schistose clasts in weathered till is conspicuously higher than in weathered till of Delta age (Péwé and Reger, 1983a, table 3). Kettles, kettle ponds and lakes, and bogs are much more abundant on moraines of Donnelly age than on moraines of Delta age, particularly on MIS 6 moraines.

From the type Donnelly terminal moraine, an extensive outwash fan spreads northward down the Delta River through a gap eroded in the outer, type MIS 6 Delta terminal moraine and associated outwash, and through the Clearwater Lake escarpment (sheet 1; fig. 9). This fan pins the Tanana River against bedrock hills of the southern Yukon-Tanana Upland (Reger and Péwé, 2002) and is continuous with Donnelly outwash that underlies the Shaw Creek flats to the north (fig. 15). Unpublished radiocarbon dates for the upper outwash gravels range from $\sim 18.0$ to $\sim 19.8$ RC ka (Alyeska Pipeline Service Company [APSC], unpub. data, 1976).

Lindholm and others (1959) initially proposed that the Clearwater Lake escarpment was cut by the braided Tanana River. Later, Péwé and others (1966) mapped discontinuous fault scarps extending for several kilometers west-northwestward along the trend of the Clearwater Lake escarpment as well as parallel fault scarps to the southwest, and Weber (1971) and Carter and Galloway (1978) proposed that the escarpment is a fault scarp. However, intensive examination of trench exposures and geophysical surveys across the feature found no evidence of faulting (APSC, unpub. data, 1976).

Along the Alaska Highway southeast of Delta Junction, the outwash fan laps against the inside of the type terminal moraine deposited by the Delta River lobe during the early (MIS 6) Delta glaciation (Reger and others, 2008a) (sheet 1). Outside and southeast of the type MIS 6 terminal moraine and its associated proximal outwash, a broad outwash apron of Donnelly age spreads northward toward the Tanana River from the terminal moraine of the Granite Creek lobe of the Granite Mountain ice cap and from terminal moraines of separate glaciers in other alpine valleys along the northwestern and northeastern fronts of the Granite Mountain block (Holmes and Péwé, 1965) (sheets 1 and 2). This outwash apron is truncated by a post-Donnelly erosional scarp, the Gerstle-Clearwater escarpment, which trends northwestward from the Gerstle River to the Clearwater Lake escarpment (Reger and others, 2008a). On the surface of the outwash apron, details of small, braided channels are generally visible from the air through thin cover sands and lowland loess, but downwind of sources of abundant sand, thick blankets of eolian sand obscure braided channels. Areas of frozen sand and loess in the eolian blanket are indicated by concentrations of small thaw ponds and depressions (Reger and Solie, 2008b). Ventifacts are generally not well formed on Donnelly outwash surfaces and are uncommon there. However, the degree of ventifact development depends on local conditions. Where surface conditions of low relief, frequent strong surface winds, local sources of adequate but not overabundant sand for cutting (but not burial), and little or no vegetation existed in post-Donnelly time, locally abundant ventifacts developed with weak surface polish and shallow pitting and grooving, but without facets or keels (Reger and others, 2008a).

Donnelly glacial advances were much more extensive along the flanks of the Granite Mountain block in alpine valleys that received ice from the Granite Mountain ice cap (Reger and others, 2008a) (sheet 1) than in isolated frontal valleys (Holmes and Péwé, 1965). The Donnelly moraine of Hajdukovich Creek, which received nourishment from the ice cap and extends barely beyond the mountain front, is sandy and dominated by granitic erratics. The loess cover is thin and discontinuous, and the weathering profile is $-48 \mathrm{~cm}$ thick (Reger and others, 2008a, fig. 11). Silt-clay caps are rare or absent in the solum.

Ice of Donnelly age barely entered the southern Alaska Highway corridor in the Gerstle River drainage and joined with ice on the west side of the Little Gerstle River glacier (Reger and others, 2008a) (sheets 1 and 2). Hamilton (unpub. data) measured sections along the bluffs of the Gerstle River and documented two drift sheets of Donnelly age, indicating that at least one readvance occurred during the last major glaciation. He collected wood from fluvial deposits between Delta-age till near the base of the bluffs and the older of two overlying tills of Don- 
nelly age and dated the wood at 25,300 $\pm 950 \mathrm{RC}$ yr B.P. (29,390 cal. yr B.P.) (GX-2179) (table 1, RC 1). Proximal outwash of Donnelly age forms a broad apron that joins with Donnelly outwash to the northwest (Reger and others, 2008a, sheets 1 and 2). Williams (1970) documented $24 \mathrm{~m}$ of Donnelly outwash gravel overlying probable drift of the Delta glaciation in a water well $-1.6 \mathrm{~km}$ beyond the surface extent of the Delta terminal moraine of the Gerstle River lobe (sheet 1, locality B), and Hamilton (unpub. data) measured 3.6 to $5.5 \mathrm{~m}$ of Donnelly outwash gravel in river sections north of the moraine. An extensive blanket of eolian sand covers the outwash apron northwest of the Donnelly terminal moraine (Reger and others, 2008a, sheet 1).
Hamilton (unpub. data) measured several sections along the bluff of the Little Gerstle River, and from the base of a 3-m-thick alluvial sand and gravel layer overlying till of Donnelly age he collected a sample of wood that dated $14,800 \pm 650 \mathrm{RC}$ yr B.P. $(17,860 \mathrm{cal}$. yr B.P.) (GX 2177) (table 1, RC 2). The Little Gerstle River glacier remained separate from the Donnelly-age glacier that flowed down the Johnson River valley.

Donnelly ice in the Johnson River valley deposited a massive, bulbous terminal moraine in the Tanana Lowland (Reger and others, 2008a) (sheet 2). In contrast to other terminal moraines of Donnelly age in the corridor, most of the Johnson River terminal moraine is composed of ice-stagnation deposits, indicating that

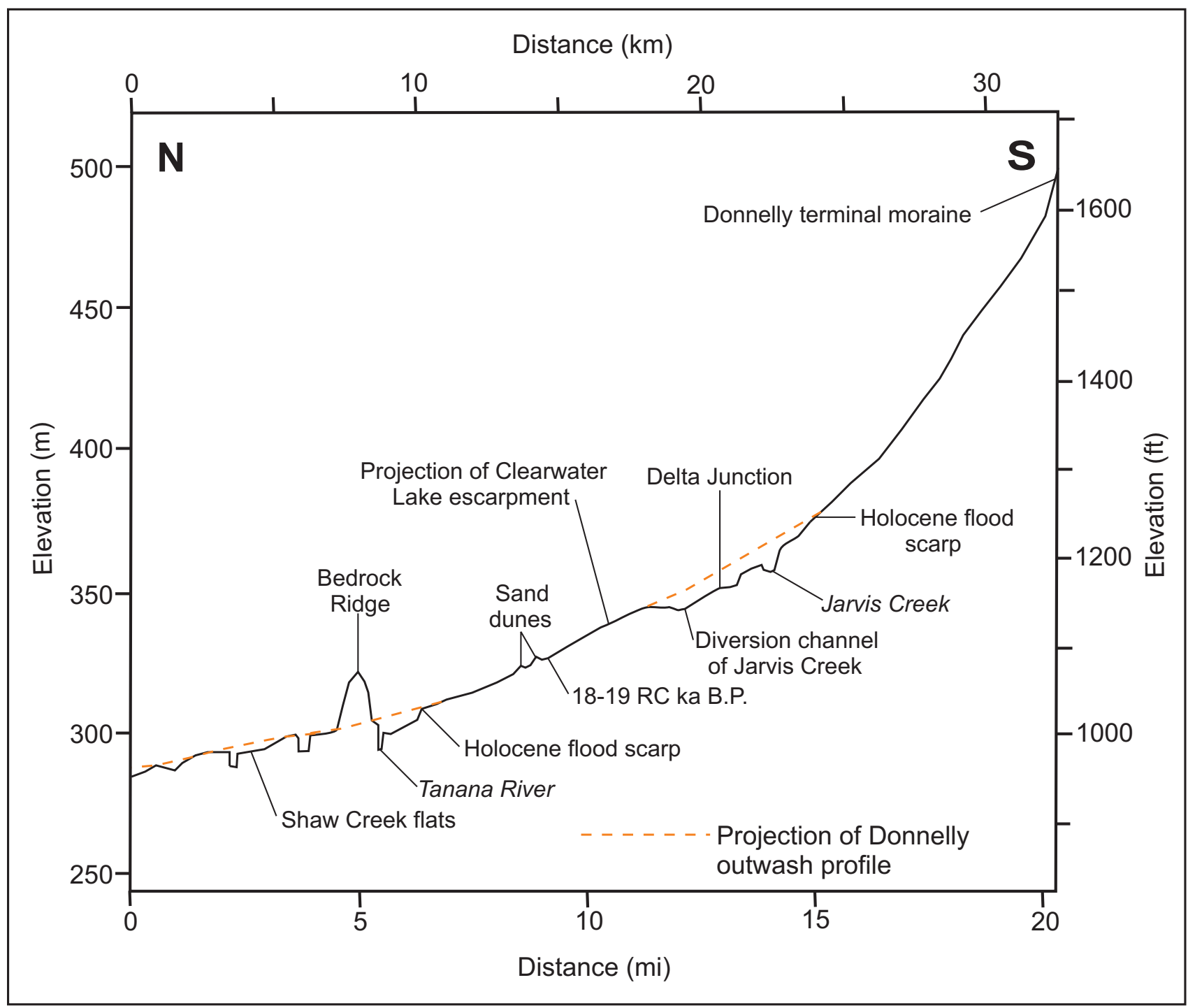

Figure 15. Bare-earth lidar-DEM-derived profile of outwash surface from type Donnelly terminal moraine in Mount Hayes D-4 Quadrangle along Richardson Highway to Shaw Creek flats in Big Delta A-4 Quadrangle, showing cultural and physiographic features (Péwé and Holmes, 1964; Reger and Péwé, 2002; Hubbard and others, 2011a). Vertical exaggeration 102. 
the narrow lower Johnson River valley significantly restricted the flow of glacier ice into the terminal zone. Huge reserves of sand and gravel aggregate are represented by extensive esker-kame complexes (fig. 16) in the terminal lobe on both sides of the Johnson River (Reger and others, 2008a, sheet 2; Reger and Solie, 2008a). Between the Alaska Highway and the mouth of the Johnson River, Donnelly-age till measures 11 to 12 $\mathrm{m}$ thick in bluff exposures and is sandwiched between two layers of outwash. The upper (recessional) outwash is a pebble-cobble gravel with scattered boulders and sand lenses, and pebbles and cobbles have discontinuous calcareous rinds and coatings. A lag of boulders up to 48 $\mathrm{cm}$ in diameter separates the upper gravel from the till beneath (fig. 17). The deeply weathered loess capping the section is $\sim 1 \mathrm{~m}$ thick. An extensive, thick eoliansand and silty-sand blanket on the southern, upvalley (inner) side of the Donnelly terminal moraine of the Johnson River lobe obscures morainal topography and was derived from the adjacent, active braided floodplain
(Reger and others, 2008a) (sheet 2). Organic material collected by Hamilton (unpub. data) from the base of the 0.9- to 3.6-m-thick eolian sand on the Donnelly moraine dated 9,830 $\pm 320 \mathrm{RC}$ yr B.P. $(11,400 \mathrm{cal}$. yr B.P.) (GX-2178) (table 1, RC-3).

A conspicuous terminal moraine of Donnelly age laps against the terminal moraine of Delta age in the upper drainage of Berry Creek (Reger and others, 2008a) (sheet 2). A pit dug into the younger moraine near Plateau Lake displayed a fairly thin weathering profile featuring a discontinuous elluvial $\mathrm{E}$ horizon up to $6 \mathrm{~cm}$ thick that is frost disturbed (Reger and others, 2008a, fig. 15). Sandy silt caps on cobbles are up to $1 \mathrm{~cm}$ thick on upper surfaces, but undersurfaces are clean, although lightly stained and weakly pitted. Rubification of the loess cover is almost certainly due to oxidation during local wildfires. We speculate that the shallow depth of the solum at that location may be a function of repeated wildfires, which prevented the development of thick surface vegetation to produce soil-weathering humic acids. Valley-train deposits of late

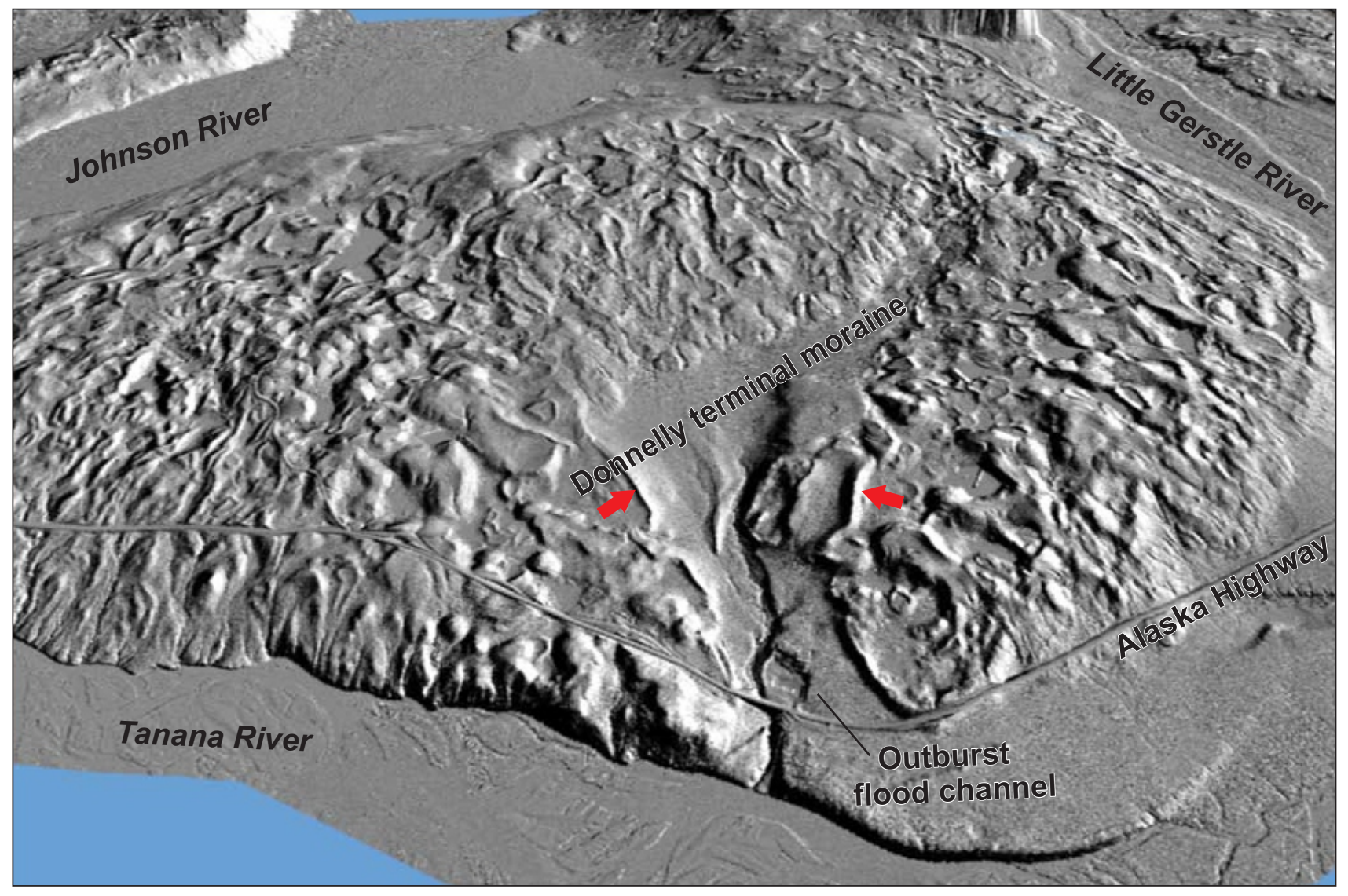

Figure 16. Oblique bare-earth lidar-derived hillshade image looking southwestward toward the massive, bulbous late Wisconsin (Donnelly) terminal moraine of the Johnson River glacier, which is mostly composed of granular ice-stagnation deposits, Mount Hayes C-2 and D-2 quadrangles. Red arrows identify esker trains associated with a probable former jökulhlaup channel cut by drainages from subglacial and ice-marginal meltwater lakes (Hubbard and others, 2011a). 
Donnelly age extend from the terminal moraine down Berry Creek to the remnant of the outwash terrace at the highway bridge (sheet 2). At the Berry Creek crossing of the Alaska Highway, the roadcut exposes $-2 \mathrm{~m}$ of outwash gravel overlying frost-shattered granitic bedrock (fig. 18). Gneiss and quartzite clasts in the outwash gravel indicate that its ultimate source is the metamorphic terrane south of the corridor (Holmes and Foster, 1968). Approximately $11 \mathrm{~m}$ of base-level lowering since late Donnelly time are demonstrated by the incision of lower Berry Creek at the highway bridge, but the ultimate cause of the downcutting (channel migration or faulting) remains obscure.

The well-preserved Donnelly terminal moraine of the Robertson River lobe is massive and stands well above subdued remnants of the Delta terminal moraine (fig. 19). A broad outwash fan that extends northeastward toward the Tanana River from the Donnelly terminal moraine is composed of coarse outwash gravel and incised by a late
Donnelly drainage channel that extends from the eskerkame complex toward the river (Reger and others, 2011) (sheet 3). This channel is likely the proglacial extension of the subglacial stream system that produced the eskerkame complex, and we suggest it was likely one source of outburst floods during the late Donnelly glaciation.

Jan Lake is impounded at $-503 \mathrm{~m}$ elevation in a reentrant in a bedrock hill by Robertson River outwash of Donnelly age. Two samples of plant remains collected by Carlson and Finney (2004) from the bottom of a $3.7 \mathrm{~m}$ core in the center of Jan Lake dated 12,410 \pm 50 RC yr B.P. (14,480 cal. yr B.P.) (CAMS-58299) and $12,439 \pm 40$ RC yr B.P. $(14,730$ cal. yr B.P.) (CAMS-58298) (sheet 3; table 1, RC-4). Pollen preserved in the core indicates that herbaceous tundra existed in that area near the end of the last major glaciation. A change to birch shrub tundra occurred $\sim 11,600$ RC yr $(-13,440$ cal. yr B.P.) ago, signaling the approaching end of the Donnelly glaciation in the area.

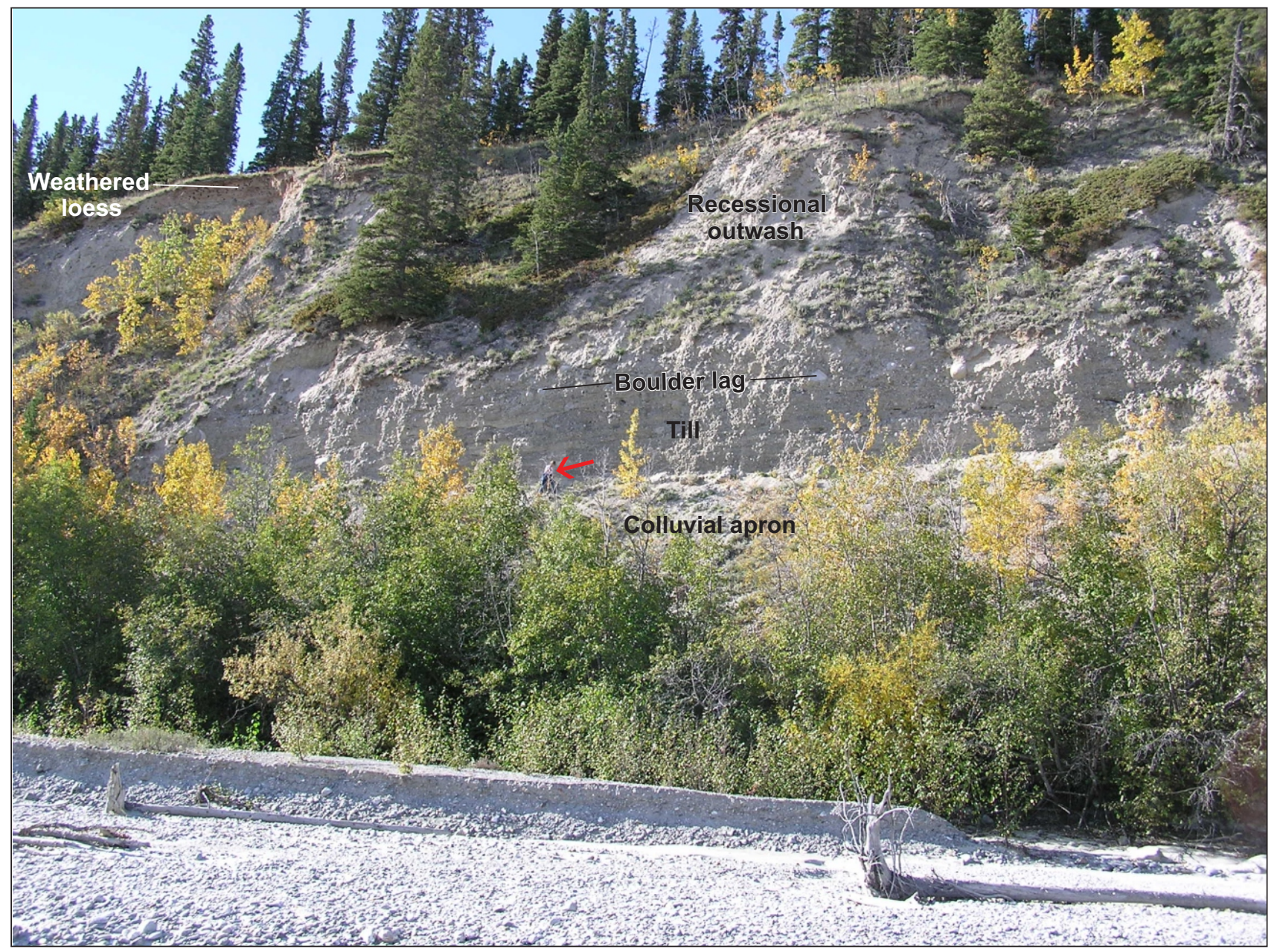

Figure 17. Bluff exposure of Donnelly glacial deposits along lower Johnson River, northeastern Mount Hayes C-2 Quadrangle (Reger and others, 2008a, fig. 13). Person indicated by small red arrow near center provides scale. Photograph taken 9/9/2006. 


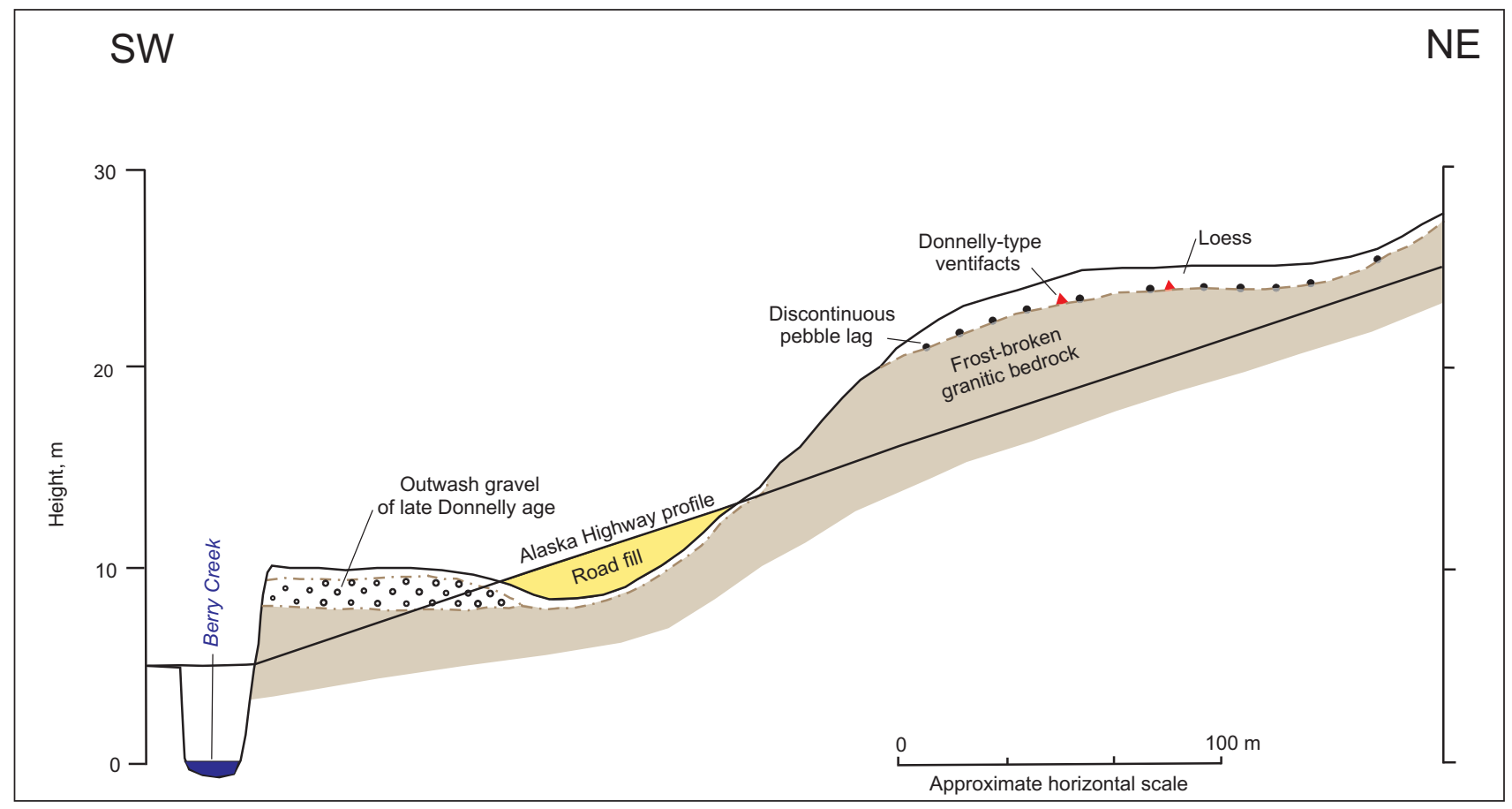

Figure 18. Cross section showing physiographic and geologic relations along Alaska Highway at crossing of Berry Creek, northwestern Mount Hayes C-1 Quadrangle (Reger and others, 2008a, fig. 16). Vertical exaggeration 6.

The lack of Donnelly-age landforms indicative of a glacier-impounded lake along the Tanana River upstream of Robertson River (Reger and others, 2011) implies that the Robertson River glacier did not block the Tanana River and create an impounded meltwater lake of significant size and duration during the Donnelly glaciation, as suggested by Duk-Rodkin and others (2004). We interpret silty sand layers with organic and silt lenses in boreholes as deep as $30 \mathrm{~m}$ for bridge foundations between Robertson River and Yerrick Creek as slackwater floodplain sediments as thick as 4.6 to $6.7 \mathrm{~m}$ interlayered with coarse fan gravels (Hemenway and Weaver, 1983).

Morainal lobes and associated outwash fans were deposited by glaciers that occupied higher alpine valleys on the northern flank of the eastern Alaska Range between Robertson River and the Tok-Tanacross lowland during the Donnelly glaciation (Carrara, 2004a, b; Reger and others, 2011) (sheets 3 and 4). Of these glacier systems, the compound glacier in the Yerrick Creek drainage was the largest. However, we found no evidence that valley glaciers from the northern flank of the eastern Alaska Range blocked the narrow Cathedral Rapids reach of the Tanana River upstream of Robertson River (Reger and others, 2011).

Fernald (1965) and Richter (1976) mapped the limit of the last major (Jatahmund Lake) glaciation in the drainages of the Chisana and Nabesna rivers -39 and $-29 \mathrm{~km}$, respectively, south of the Alaska Highway, well outside the Alaska Highway corridor. From the ice limits in these river valleys, extensive fans of granular outwash spread northward to the Yukon-Tanana Upland (sheets 5 and 6).

\section{Correlation}

Donnelly moraines have the highest local relief of late Pleistocene moraines in the corridor, and outwash features of Donnelly age are extensive, locally overwhelming moraines and outwash of the Delta glaciation. Solum depths, as defined by stained clasts and weathered metamorphic and granitic components, generally range from 30 to $85 \mathrm{~cm}$ in tills of Donnelly age and up to $90 \mathrm{~cm}$ in outwash (Reger and others, 2008a, 2011). Silt caps are generally thin and rare. B horizons range in color from light olive-brown $(2.5 \mathrm{Y} 5 / 6)$ to brown $(10 \mathrm{YR} 5 / 3)$ to dark yellowish brown (10YR4/3). Clasts of foliated metamorphic lithologies, which are susceptible to frost splitting, are more common in Donnelly tills and outwash than in their Delta equivalents. We correlate post-Donnelly soils with the Stewart soil in the western Yukon (table 2).

\section{Age}

Although opinions have differed in the past (Reger and Péwé, 2002), most workers agree that the Donnelly glaciation is late Wisconsin (MIS 2) in age (Hamilton, 1994). Maximum-limiting dates for the last major glaciation in or near the corridor are represented by two radiocarbon 


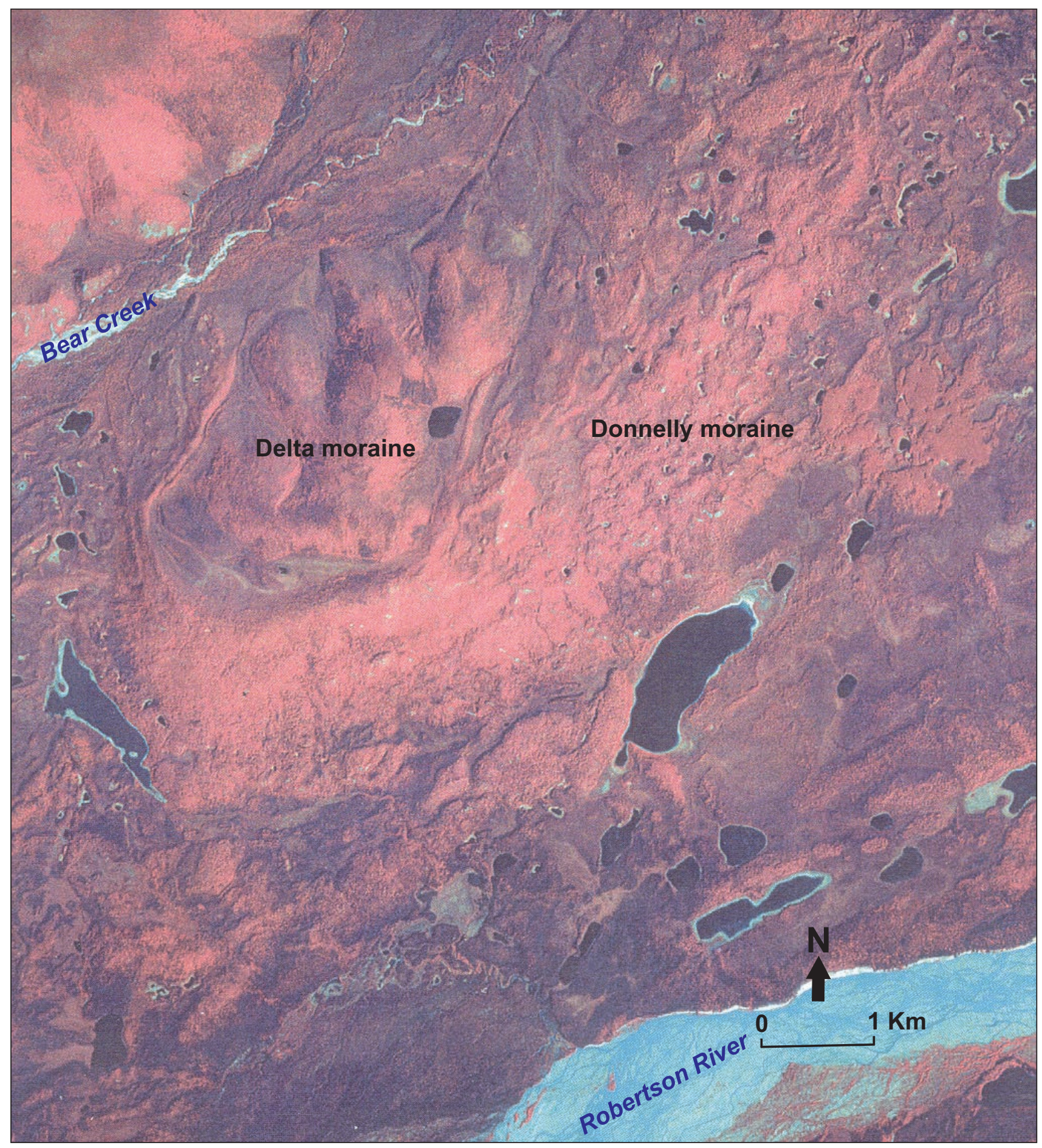

Figure 19. Vertical false-color infrared aerial photograph comparing surface forms of Robertson River moraines of Delta and Donnelly ages, southeastern Mount Hayes C-1 and northeastern Mount Hayes B-1 quadrangles (Alaska High Altitude Photograph ALK 60 CIR 8487, taken August 1980) (Reger and others, 2011, fig. 10).

ages. Hamilton's unpublished age of 25,300 $\pm 950 \mathrm{RC}$ yr B.P. (29,390 cal. yr B.P.) (GX-2179) (table 1, RC-1) for wood beneath the oldest Donnelly till of the Gerstle River lobe is very close to a $24,900 \pm 200 \mathrm{RC}$ yr B.P. (QL-1369) age obtained by Ten Brink and Waythomas (1985) for soil organics beneath outwash related to the early Donnelly terminal moraine in the Little Delta River valley just west of the corridor. A minimum-limiting date for the peak of the Donnelly glaciation in the Little Gerstle River drainage is $14,800 \pm 650 \mathrm{RC}$ yr B.P. (17,860 cal. yr B.P.) 
(GX 2177) (table 1, RC-2) for wood from the base of a 4.5-m-thick fluvial sand overlying till of Donnelly age.

Matmon and others (2010) collected 11 samples, including four collections of 25 to 30 quartzose pebbles, from the type terminal moraine of the Donnelly glaciation near Donnelly Dome for ${ }^{10} \mathrm{Be}$ cosmogenic-exposure dating, and obtained moraine-stabilization ages between $11.9 \pm 1.3 \mathrm{ka}$ and $23.6 \pm 2.6 \mathrm{ka}$ for ten of the samples. Most of their samples indicate that the culmination of the Donnelly glaciation occurred $\sim 17.0 \mathrm{ka}$, but others cluster near the end of the last major glaciation.

Farther east and just south of the corridor, Young and others (2009) obtained ${ }^{10} \mathrm{Be}$ moraine-stabilization ages of $16.6 \pm 0.4 \mathrm{ka}$ to $16.3 \pm 0.4 \mathrm{ka}$ with a mean of $16.5 \pm$ $0.1 \mathrm{ka}$ for four boulders on the crest of the north lateral moraine of Donnelly age along the northern tributary of upper Bear Creek near Fish Creek.

North of the corridor in the Yukon-Tanana Upland, a combination of ${ }^{10} \mathrm{Be}$ and ${ }^{26} \mathrm{Al}$ cosmogenic-exposure ages for four granitic boulders on the crest of a lateral moraine of the Salcha glaciation in Ramshorn Creek valley indicates that this moraine stabilized between $22.8 \pm 6.9 \mathrm{kya}$ and $21.2 \pm 5.9$ kya (Briner and others, 2005). Dating of the younger nearby Ramshorn end moraine, to which Weber (1986) assigned a late Holocene (MIS 1) age, indicates that the Ramshorn advance actually occurred $\sim 19$ to $\sim 18$ kya (MIS 2).

Radiocarbon dating and ${ }^{10} \mathrm{Be}$ cosmogenic-exposure dating in the upper Nenana River and Swift River valleys in the central and western Alaska Range indicate that the most extensive moraines of the last major glaciation were deposited there between 21 and 20 kya, followed by recession until 19 to $17 \mathrm{kya}$; readvances later occurred between 17 and 16 kya and 14 and 12 kya (Briner and Kaufman, 2008).

\section{Holocene glaciation}

Features

Numerous Holocene end moraines and rock glaciers occupy upper mountain valleys in the Sheep Creek area of the eastern Alaska Range (Carrara, 2004a; Reger and others, 2011) (sheet 3). These small, young moraines range in average elevation from $\sim 1,395$ to $\sim 1,771 \mathrm{~m}$, with a mean of $1,616 \mathrm{~m}(\mathrm{n}=10)$. Rock glaciers in the area range in average elevation from $-1,303$ to $\sim 1,820$ m elevation, with a mean of $-1,540 \mathrm{~m}(\mathrm{n}=16)$. Modern snowline, as indicated by a single small glacier in a west-facing cirque just south of the corridor, is at 1,668 m elevation.

A small Holocene moraine, previously identified as a rock glacier by Cararra (2004a), impounds a shallow tarn at the head of the west fork of Sheep Creek at 1,585 m elevation (Reger and others, 2011) (sheet 3). A shallow test pit dug into this moraine exposed an inceptisol developed in a coarse till of angular schist pebbles and cobbles. Loess has infiltrated the open-work gravel to a depth of $-30 \mathrm{~cm}$. Staining of till stones and their 3-mm-thick silt-clay caps in the B horizon is dark reddish brown (5Y3/2) (Reger and others, 2011, fig. 14).

\section{Age}

Using ${ }^{10} \mathrm{Be}$ cosmogenic-exposure and lichenometric techniques, Young and others (2009) dated the stabilization of at least one Holocene moraine in upper Bear Creek just south of the corridor at $\sim \mathrm{AD} 900$ and speculated that coeval moraines are present in a neighboring valley. They estimated the ages of younger moraines in the drainage by lichenometry at AD 1290, - AD 1640, AD 1860, - AD 1910, and $-A D 1930$.

\section{LATE PLEISTOCENE PALEOFLOODS}

Péwé (1965, p. 38; 1975a, p. 68) proposed a simple model of widespread, alternating cycles of aggradation and erosion in the Tanana River valley that were related to cycles of glaciation and interglaciation, respectively, in the Alaska Range. He suggested that the "great alluviation" occurred in the Tanana River valley during the penultimate (Delta) glaciation and that several clearwater lakes, including Harding, Birch, and Quartz lakes, were impounded behind the resulting massive alluvial fills at the mouths of re-entrants along the southern margin of the Yukon-Tanana Upland. During subsequent deglaciations, the thick alluvial fill in the Tanana River valley was dissected, cutting prominent terrace scarps up to $30 \mathrm{~m}$ high along the Tanana River upstream from Fairbanks. During the last major (Donnelly) glaciation, aggradation was renewed and was followed by local Holocene dissection.

In the Interior, evidence of massive Pleistocene flooding is documented along the Yukon River and its tributaries, the Porcupine and Charley rivers (Thorson and Dixon, 1983; Thorson, 1989; Froese and others, 2003). While conducting research for their summary paper on the Pleistocene history of the Cordilleran ice sheet in Alaska, Hamilton and Thorson (1983) unexpectedly learned that no evidence had been recognized up to that time for outburst flooding in the upper Tanana River drainage, and cited (p. 49) communications from their U.S. Geological Survey colleagues Dave Carter and Hank Schmoll, who had mapped along the upper Tanana and Tok rivers and in the Mentasta Pass area. A little later, Schmoll (1984) postulated that Glacial Lake 
Atna in the Copper River basin had drained subglacially through Mentasta Pass. Such subglacial drainage would have dumped considerable meltwater into the upper Tanana River across the Tok fan.

A principal achievement of our investigative program in the Alaska Highway corridor was the recognition of widespread evidence for multiple late Pleistocene outburst floods in the upper Tanana River drainage.

\section{Tok expansion fan}

The most obvious evidence for numerous late Pleistocene paleofloods in the upper Tanana River drainage is the Tok expansion fan, which occupies most of the Tok-Tanacross lowland. Although described as an alluvial fan (Williams, 1970, p. 43), most of the Tok fan lacks the characteristics of a typical alluvial fan, which include limited radial lengths (generally $<10$ to $15 \mathrm{~km}$ ), high values for radial slopes $\left(1.5^{\circ}\right.$ to $\left.25^{\circ}\right)$, and a planoconvex cross profile (Blair and McPherson, 1994). The Tok fan is up to $39 \mathrm{~km}$ wide, has radii that vary in length from -13 to $-42 \mathrm{~km}$, and the fan slopes radially from $0^{\circ} 04^{\prime}$ to $0^{\circ} 14^{\prime}$ (Reger and others, 2011). This morphology is typical of fans affected by sheet flows (Blair and McPherson, 1994). Like Foster (1970) and Carrara (2006), we recognize older and younger parts of the unusually broad and low-gradient Tok fan. The older, western, well-drained, expansion fan surface is 4.8 to $10 \mathrm{~m}$ higher than the surface of the inset, younger, eastern Tok River alluvial fan (fig. 20). Deposits and surface features clearly demonstrate that the massive Tok expansion fan was deposited by extraordinary flood processes that were very different from the normal stream activities (including flooding) of the Tok River during deposition of the younger Tok River alluvial fan.

Logs of water wells and airborne geophysical surveys indicate that the alluvium in the Tok fan is $>30 \mathrm{~m}$ thick (Williams, 1970; Reger and others, 2011), and nowhere in gravel pits as deep as $11 \mathrm{~m}$ was a significant unconformity observed, indicating that at least the upper part of the fan was deposited during the last major glaciation. The Tok fan is generally composed of a series of 0.9- to 1.2-m-thick, tabular layers of massive clast- and matrixsupported pebble gravels with some medium to coarse sand, numerous cobbles, and rare boulders. Less common are layers of crudely bedded, pebbly sand (Reger and others, 2011, fig. 20). Upper and lower contacts are sharp and generally parallel the fan surface, although scattered beds have oblique tangential cross-bedding dipping north-northeast. Clasts are subrounded to rounded and are dominantly composed of Alaska Range lithologies, with 4 to 20 percent vesicular volcanic clasts derived from the Wrangell Mountains (Holmes, 1965). Sand lenses up to $\sim 0.9 \mathrm{~m}$ thick represent channel fills. Sieve analyses demonstrate that the sand content in gravel beds ranges from 16 to 35 weight percent, with clast-supported gravels containing less sand and fine fraction (Reger and others, 2011, table 3). We suggest that gravel-rich beds represent bedload components deposited by water-dominated flood surges and that matrix-supported gravels and pebbly sands preserve components of the suspended load that were deposited by sandier, hyperconcentrated flood flows. However, we urge caution in defining the composition of the depositing medium only on the basis of textural values because a significant part of the suspended load could have remained in suspension due to turbulence and could have been flushed down the Tanana River (Smith, 1986, p. 5).

We found several extraordinarily large flood boulders of Alaska Range rock types in a roadside gravel pit (Material Site 62-2-005-2) in the terrace remnant east of the Tok River, and in nearby gravel pits; a single flood boulder is present as lag in the Tok River (fig. 20, localities C-E). No other very large flood boulders have been found in the Tok fan, even in deep gravel pits. Particularly instructive was the in-situ exposure in Material Site 62-2-005-2 of an exceptionally large greenstone flood boulder that measured $2.0 \mathrm{~m}$ in its longest dimension (fig. 21). The bottom of the flood boulder was formerly $-2.4 \mathrm{~m}$ below the fan surface in the upper part of a clean, clast-supported pebble gravel with numerous subrounded to rounded polymictic cobbles and a slight pebble imbrication that indicates flow from the head of the Tok expansion fan. Also noteworthy was the presence of an 11-cm-thick zone of disturbance beneath the boulder, in which the pebbles were generally oriented parallel to the boulder surface. We suggest that the pebbles in this zone were reoriented at the time the boulder was deposited.

The lack of glacial till in the Tok expansion fan indicates that the extraordinarily large boulders were not deposited directly from glacial ice, as inferred by Carter and Galloway (1978). The absence of stratigraphic features normally deposited by water floods, including common cut-and-fill structures, ripples, and widespread cross-bedding, indicates that the boulders were not deposited by typical water floods either. Instead, we propose that the very large boulders in the massive, tabular gravels and pebbly sands in Material Site 62-2-005-2 and elsewhere in the remnant of the Tok fan east of the Tok River were deposited as dropstones from icebergs that were carried northeastward by flood surges (jökulhlaups) through the Tok River valley (Reger and others, 2011). The limited distribution of the excep- 


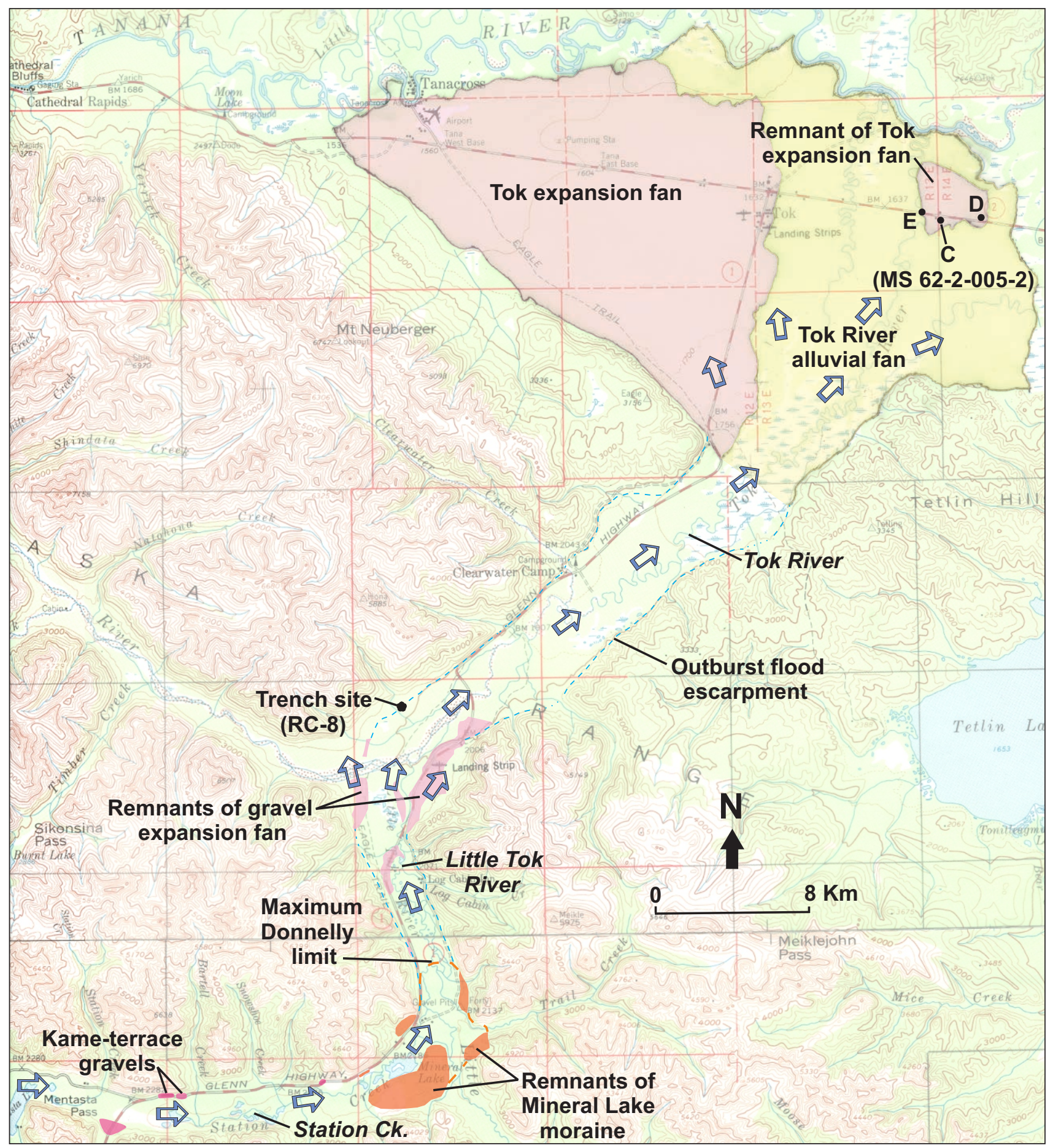

Figure 20. Map showing course of outburst floods (blue-gray arrows) from Mentasta Pass to Tok expansion fan during Donnelly glaciation relative to locations C-E of large flood boulders in remnant Tok expansion fan east of the Tok River (Reger and others, 2011, fig. 22); Material Site 62-2-005-2 is located at C. Landforms in upper Tok River and Little Tok River valleys reinterpreted from Foster (1970) and Richter (1976) and verified by field observations. Flood escarpments in Tok River valley dashed where discontinuous and dotted where buried and inferred. Black dot marks site of trenches excavated by Carver and others (2010) and location of radiocarbon sample RC-8. 
tionally large flood boulders of Alaska Range rock types in the Tok fan indicates that the main flood surges were directed northeastward down the Tok River valley and the flood boulders were deposited at the mouth of the valley (fig. 20). We suggest that the pebbles beneath the large greenstone flood boulder in Material Site 62-2-005-2 were reoriented when the boulder plunged as a dropstone onto the submerged fan surface. The lack of rounded corners and edges in the Tok fan suite of flood boulders, such as exists in the suite of traction-load flood boulders in the Sears-Berry creeks strath-terrace sites (Reger and others, 2008a, fig. 27), indicates that the Tok fan boulders were quickly buried by flood-surge gravels. The interlayered character of the flood gravels and sands and the clear differences in their compositions indicate that the large-magnitude flows pulsated, perhaps as a result of two main hydraulic processes. First, temporary blockages of subglacial drainageways through which the jökulhlaup floods bypassed the former glacier dam could have generated flow pulses (Sturm and others, 1987; Sturm and Benson, 1989; Tweed and Russell, 1999). Second, hydraulic pulses could have resulted from flood flows debouching onto the Tok expansion fan and spreading as upper flow-regime sheet flows across the gently sloping fan surface (Blair and McPherson, 1994).

The surface of the Tok expansion fan is laced with a complex of 1 - to 3-m-deep, digitating, anastomosing, and cross-cutting surface stream paleochannels that radiate from the mouth of the Tok River valley toward the northern and western fan margins (fig. 22). The complex is covered by 15 to $30 \mathrm{~cm}$ of loess that bears a late Donnelly to Holocene soil, indicating that the flood events responsible for the paleochannels occurred during the Donnelly glaciation.

The character of the surface channels visible in lidar hillshade imagery provides clues concerning paleoflooding on the Tok expansion fan. Paleochannels group by

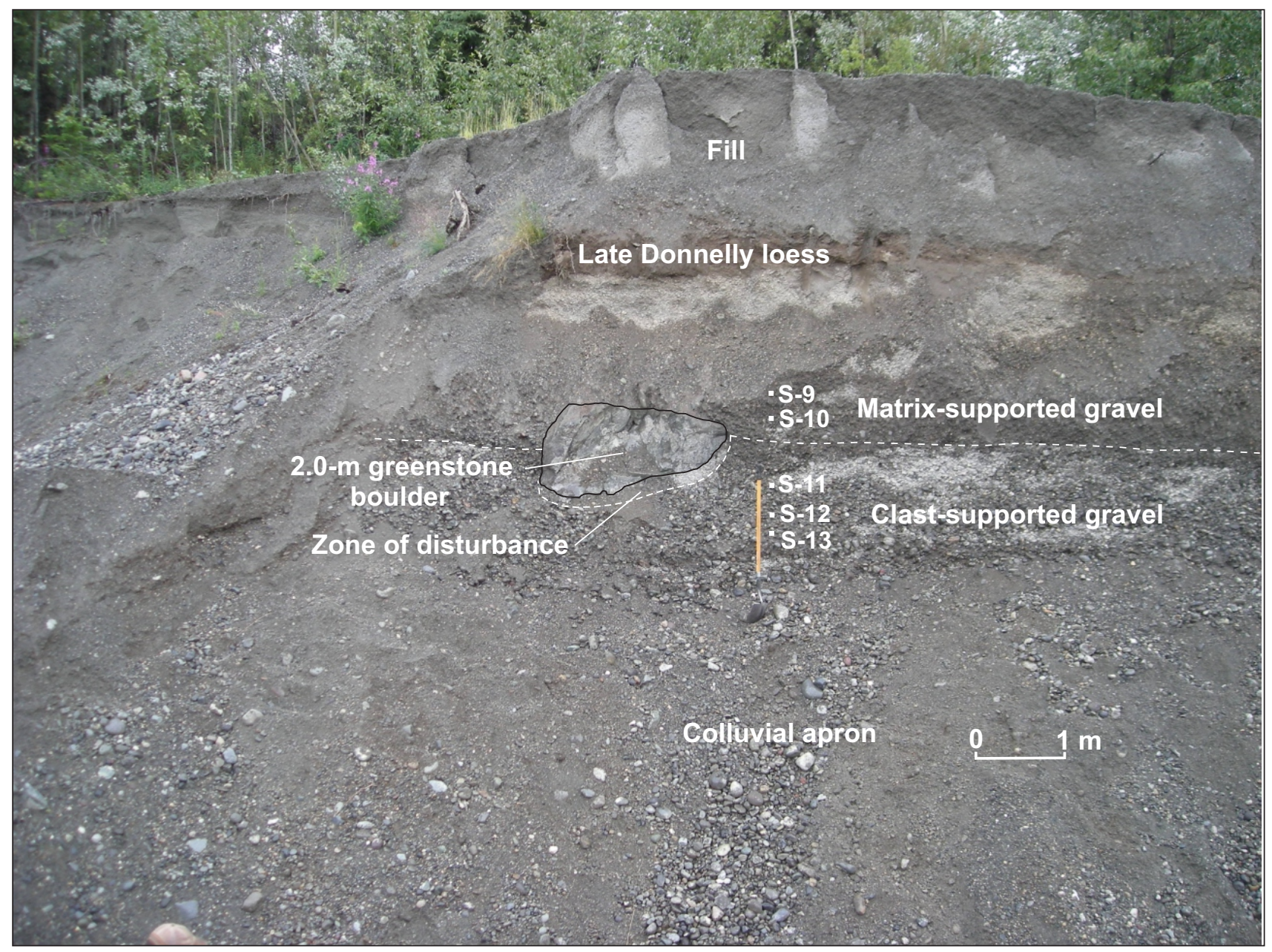

Figure 21. Extraordinarily large in-situ greenstone flood boulder (outlined in black for clarity) in clast- and matrix-supported jökulhlaup gravels, and sample locations in south wall of Material Site 62-2-005-2, northeastern Tok fan (fig. 20), southwestern Tanacross B-4 Quadrangle (modified from Reger and others, 2011, fig. 18). Photograph taken 7/29/2008. 
similar orientation (means estimated by visual inspection) into seven classes (fig. 22, table 3). The mean channel orientation in group $\mathrm{I}\left(-\mathrm{N} 88^{\circ} \mathrm{W}\right)$ at the west end of the expansion fan progressively changes through groups IIIV to $\sim \mathrm{N} 21^{\circ} \mathrm{W}$ at Tok, consistent with eastward-shifting radial deposition and implying a progressive decrease in the volumes of jökulhlaups from the Tok River valley as meltwaters were decanted from Glacial Lake Atna during the Donnelly glaciation. In group III the volcanic bedrock knob north of the highway diverted north-northwestflowing floods and protected the leeward fan surface from the most erosive effects of flooding. Northwest-blowing winds cut ventifacts on bedrock exposures and colluvial debris on the southeastern slope of the bedrock knob (Reger and others, 2011). Sand deposited by eolian processes and waning floods occupies the surface-channel complex on the expansion fan and exhibits cross-bedding. Group V documents the transition east of Tok from the jökulhlaupdominated Tok expansion fan to the river-dominated Tok River alluvial fan (group VI). The terrace remnant of the Tok expansion fan east of Tok River (group VII) is covered by an eolian sand blanket and dunes, and surface paleochannels are not visible.

\section{Other expansion fans}

Prominent flood features of late Pleistocene age in the Tanana River drainage west of Tok include other expansion fans that range in size up to the large, compound expansion-fan complex of Donnelly and Delta(?) ages that impounds Lake George and Moosehead Lake (Reger and others, 2008a, fig. 33) (sheet 2). These large, channel-related expansion fans typically impound slackwater basins in floodplain marginal areas.

\section{Flood terraces and bars}

Streamlined flood terraces, some rock-defended, and longitudinal flood bars were deposited by Donnelly jökulhlaups in the upper Tanana River valley, as were similar deposits during the colossal floods from Glacial Lake Missoula in the Channeled Scablands of east-central Washington (Baker, 1973, 2009; Baker and others, 1987) (sheets 2 and 3). Their streamlined forms apparently presented the least resistance to the passage of the floods that formed or followed them (Baker, 1973; Komar, 1983).

Initially, our attention was drawn to two large, aligned and streamlined flood terraces with sharp ends pointed downstream along the Tanana River east of Dot Lake Village at the eastern boundary of the Mount Hayes Quadrangle (fig. 23). The upstream flood terrace is rock defended (fig. 24) and was described by Holmes (1965) as being composed mostly of silt and sand. He described
Table 3. Comparison of jökulhlaup paleochannel networks on Tok expansion fan.

\begin{tabular}{|c|c|c|}
\hline $\begin{array}{c}\text { Channel } \\
\text { zone }\end{array}$ & $\begin{array}{c}\text { Alaska Highway } \\
\text { milepost (AMP) } \\
\text { intercepts }\end{array}$ & $\begin{array}{c}\text { Estimated } \\
\text { mean channel } \\
\text { orientation }\end{array}$ \\
\hline I & $1326.5-1324.7$ & $\mathrm{~N} 88^{\circ} \mathrm{W}$ \\
\hline II & $1324.7-1323.3$ & $\mathrm{~N} 54^{\circ} \mathrm{W}$ \\
\hline III & $1323.3-1318.1$ & $\mathrm{~N} 28^{\circ} \mathrm{W}$ \\
\hline IV & $1318.1-1313.7$ & $\mathrm{~N} 21^{\circ} \mathrm{W}$ \\
\hline V & $1313.7-1312.8$ & $\mathrm{~N} 2^{\circ} \mathrm{E}$ \\
\hline VI & $1312.8-1309.4$ & $\mathrm{~N} 5^{\circ} \mathrm{E}$ \\
\hline VII & $1309.4-1308.4$ & - \\
\hline
\end{tabular}

the downstream terrace as being composed of gravel from local sources. Carter and Galloway (1978) mapped both terraces as questionable till of the Delta glaciation. Our examination of the 33-m-high southeastern face of the downstream terrace revealed that the upper $3 \mathrm{~m}$ are composed of coarse, clean, massive pebbly sand with numerous cobbles up to $20 \mathrm{~cm}$ diameter, and rare, subangular to subrounded granitic boulders up to $1.1 \mathrm{~m}$ diameter (fig. 25). This coarse sandy unit is underlain by at least $6 \mathrm{~m}$ of clean, coarse to very coarse sand with numerous pebbles. Massive sands such as these deposits represent suspended loads laid down during hyperconcentrated flood flows (Costa, 1988). An exceptionally large (2.7-mdiameter), subrounded granitic boulder (fig. 23) sits on the opposite (southwestern) side of the same high terrace near the base of a high escarpment scoured during one or more massive late- or post-Donnelly floods, perhaps one of several very large, flood-transported monoliths buried deep in the terrace just downriver from the terminal moraine of the Robertson River lobe (sheets 2 and 3).

Between Alaska Highway milepost (AMP) 1369.5 and AMP 1364.5, the Alaska Highway traverses an extensive flood bar that was deposited by megafloods during the Donnelly glaciation (Reger and others, 2008a) (fig. 26). The bar is bounded on the north by a 5.5 -m-high floodscoured scarp (sheet 2). The southern flank is concave and adjoins a shallow, alluvium-filled flood channel to the south. Both the upvalley and downvalley ends are pointed, imparting a streamlined form that indicates the feature is a longitudinal flood bar (O'Connor, 1993). A hand-survey across the bar along the incised channel of upper Sam Creek demonstrates that the bar has been tectonically tilted (Carver and others, 2008a, fig. 13). This feature was previously mapped as questionable drift of the Delta glaciation (Carter and Galloway, 1978). 


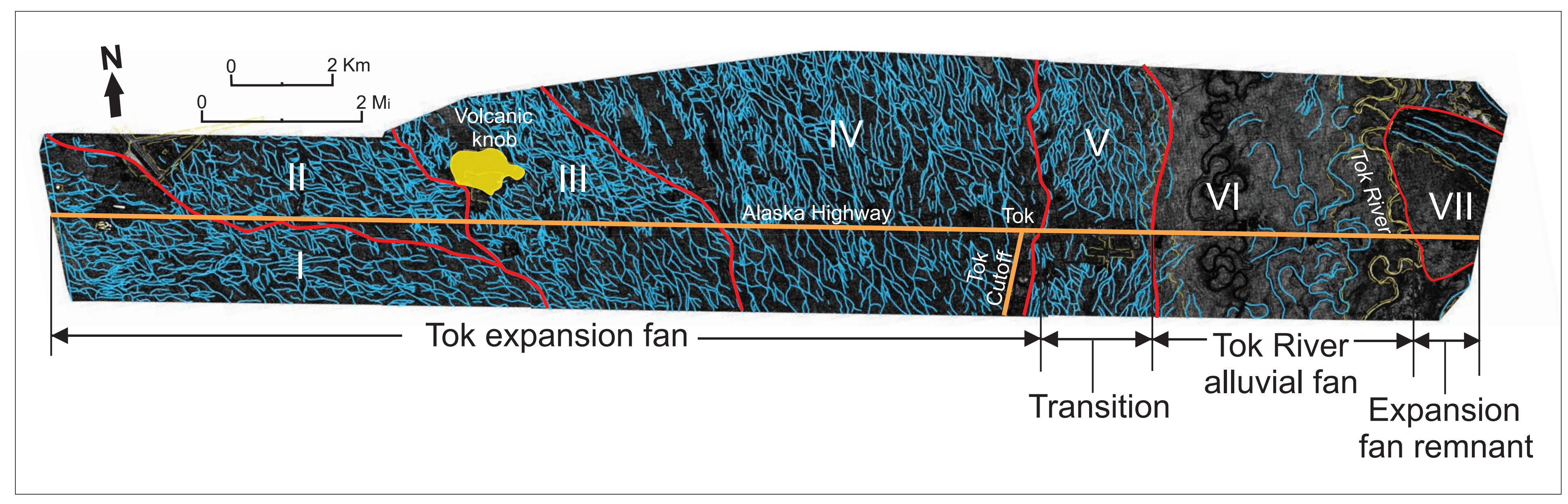

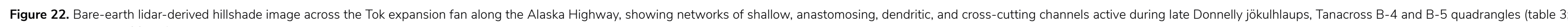
Hubbard and others, 2011b). 
Intentionally left blank 


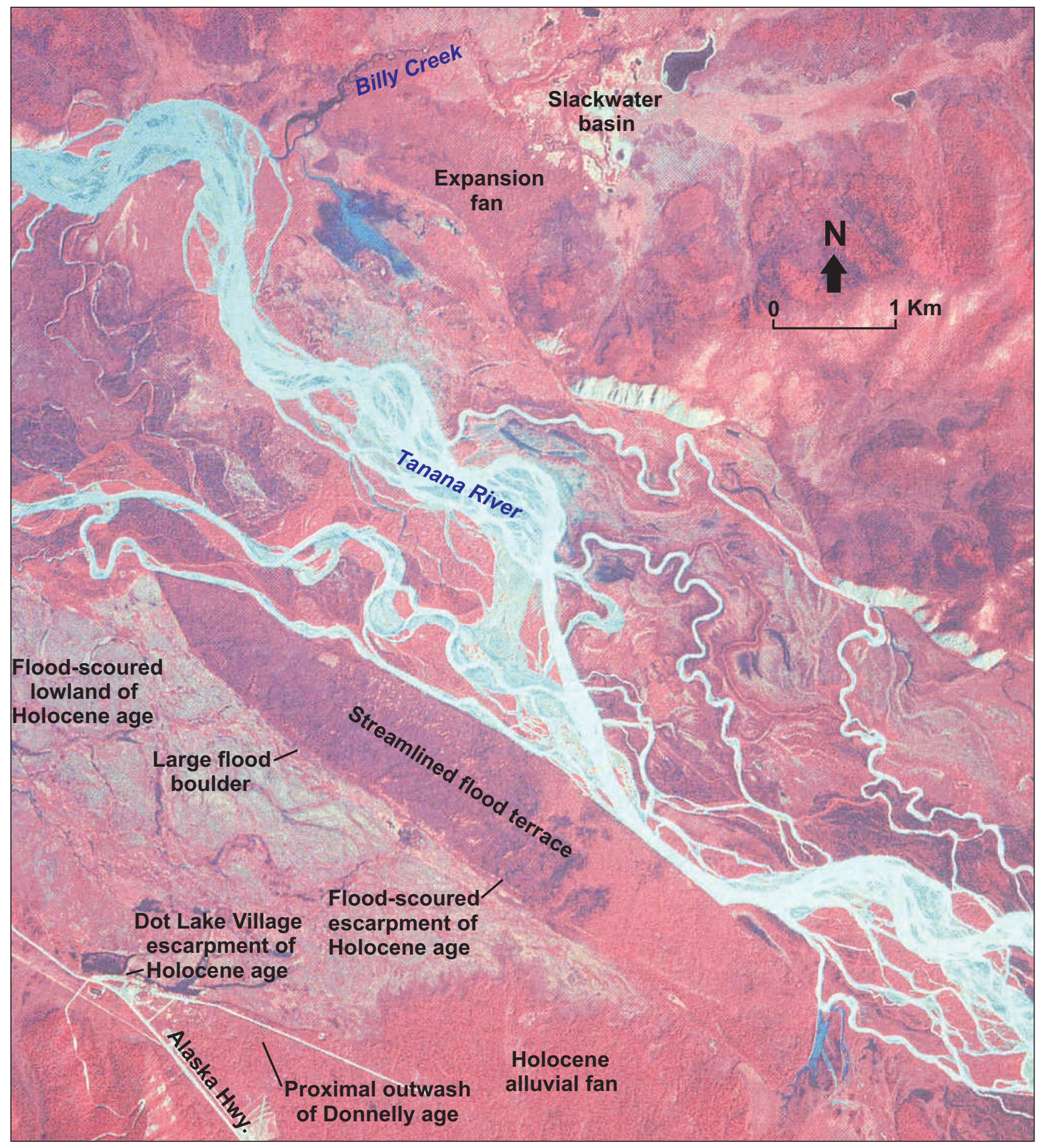

Figure 23. Vertical false-color infrared aerial photograph showing landforms related to large-magnitude flooding of upper Tanana River near Dot Lake Village, northeastern Mount Hayes C-1 Quadrangle (Alaska High Altitude Photograph ALK 60 CIR 8548, taken August 1980) (modified from Reger and others, 2008a, fig. 18).

Near-surface deposits in the longitudinal bar are at least $8.8 \mathrm{~m}$ thick, sporadically frozen to depths $>8 \mathrm{~m}$, and consist dominantly of well-drained, polymictic, sandy pebble gravels with scattered cobbles and boulders (Brazo, 1988; Reger and Solie, 2008a). Examination of the walls of several gravel pits indicates that subrounded to rounded granitic boulders reach a maximum diameter of $\sim 1.1 \mathrm{~m}$ in these flood gravels. The gravels are generally lightly stained by iron oxides to a depth of at least $1.4 \mathrm{~m}$, perhaps by near-surface groundwater rich in tannins when permafrost was more extensive. 


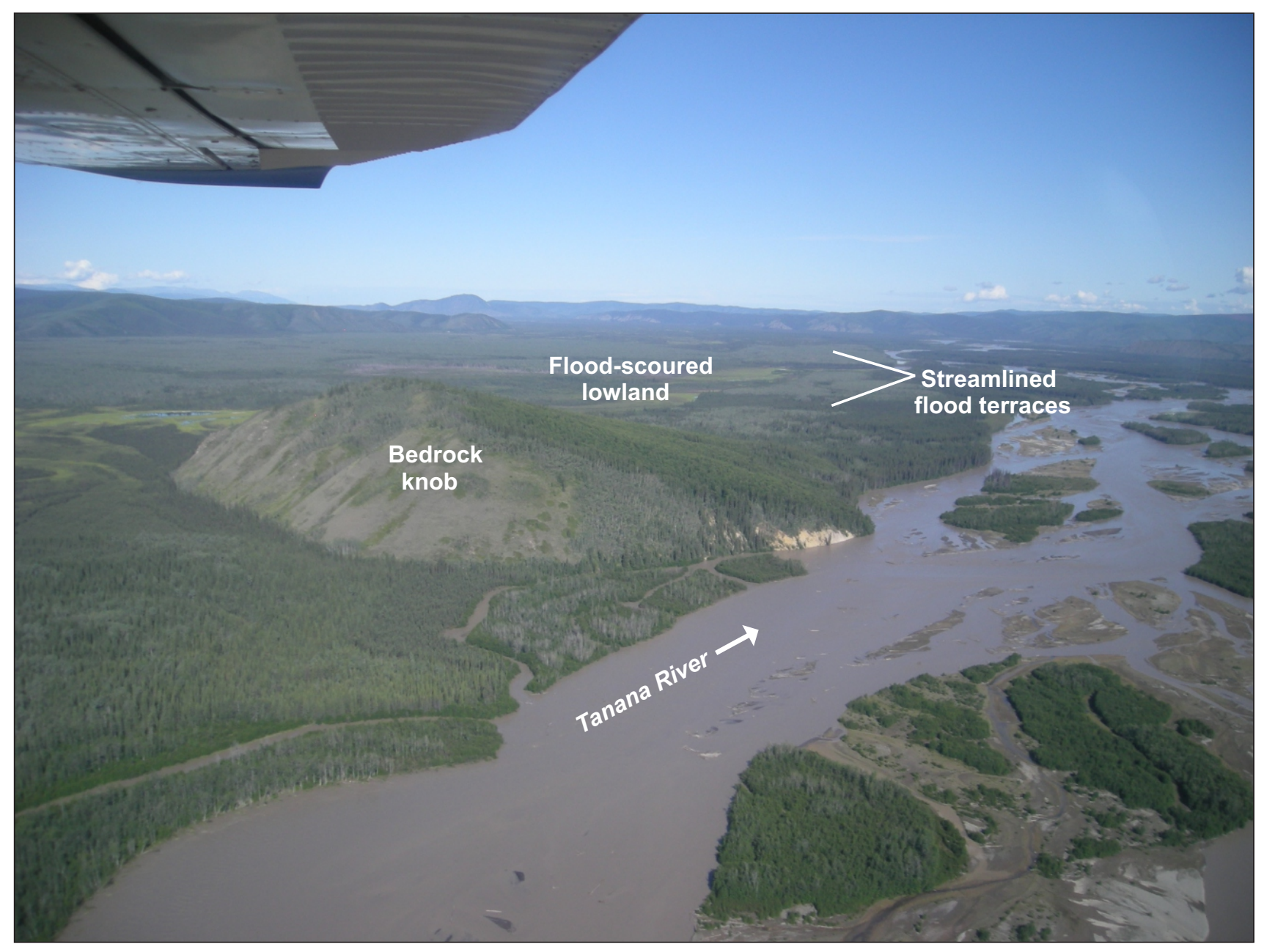

Figure 24. Aerial view northwestward of streamlined flood terraces of Donnelly age, east-central Mount Hayes C-1 Quadrangle (Reger and others, 2008a, fig. 17). Nearest flood terrace is bedrock defended. Photograph taken 7/13/2007.

However, clasts have thin $(<1 \mathrm{~mm})$, discontinuous coatings of calcium carbonate to depths $\geq 1 \mathrm{~m}$, indicating that more extensive former coatings and rinds were partially dissolved by acidic groundwater or that groundwater was alkaline at times, perhaps when permafrost thawed. An open geochemical system is indicated. Thin $(\leq 0.5 \mathrm{~mm})$ silt-clay caps are present on clasts to a depth of $-1.2 \mathrm{~m}$, but no clay rinds or bridges were observed. In the upper $80 \mathrm{~cm}$ of the gravels, many schistose and granitic clasts are split or crumbly, respectively, due to frost weathering in the active zone. Typically, this zone of weathered clasts is much thicker in gravels of Delta age. A single, small ice-wedge cast at the top of the terrace gravel has a filling of sandy gravel with some silt (Reger and others, 2008a) (fig. 27). The size of this ice-wedge cast is typical of ice wedges formed during the Holocene in Donnelly outwash north of Delta Junction (APSC, unpub. data, 1976). The thin loess cap on the terrace bears a weakly developed post-Donnelly soil profile.
Compelling evidence that the longitudinal bar was deposited during large-magnitude floods are the widespread surface waves composed of coarse to very coarse sand with trace to some silt, numerous subrounded to rounded pebbles, and scattered cobbles (fig. 28). Similar waves, identified as flood ripples, are typically associated with extensive flood bars in the Channeled Scabland of east-central Washington state (Baker, 1973, 2009; Baker and others, 1987). Wave complexes as well as single waves are present on the longitudinal bar, and nine wave crests, measured in the field, trend $185^{\circ}$ to $240^{\circ}$ azimuth, roughly normal to the trend of the longitudinal bar. Several waves are sectioned by the Alaska Highway (fig. 29). Wave heights vary from 0.6 to $2.7 \mathrm{~m}$, averaging $\sim 1.6 \mathrm{~m}$. Median diameters of the largest cobbles average $-8-9 \mathrm{~cm}$. The coarse texture of these deposits indicates that the waves were deposited by water, not wind. Wave orientations indicate that the former floodwaters flowed west-northwest 


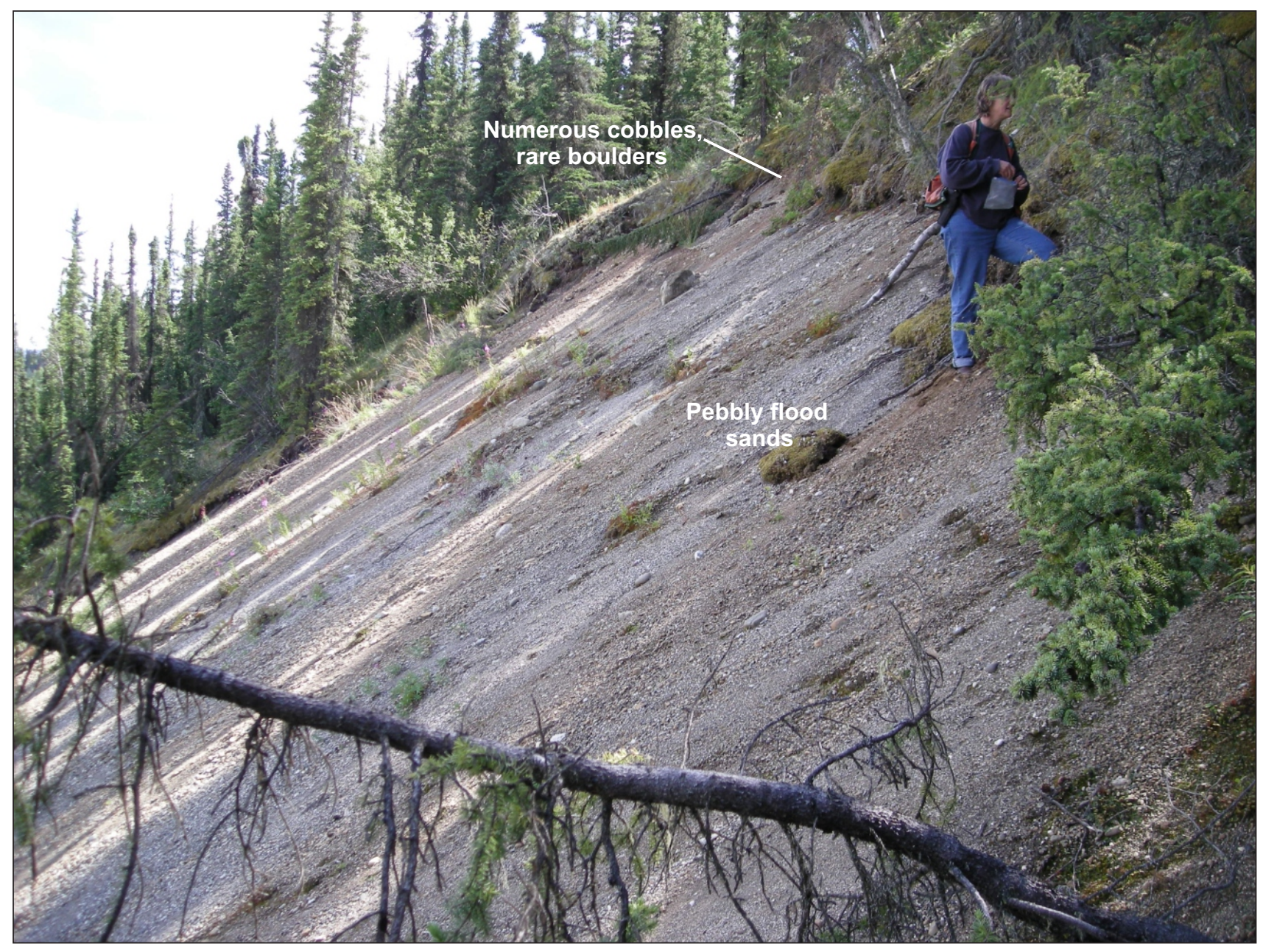

Figure 25. River-bluff exposure of pebbly sand flood deposits, northeastern Mount Hayes C-1 Quadrangle (Reger and others, 2008a, fig. 19). Photograph taken 7/13/2007.

in this reach of the Tanana River valley. Dates of small detrital charcoal fragments in fault-deformed silt (loess) exposed in paleoseismic trenches DTJ I and DTJ III overlying sands deposited by late Donnelly jökulhlaups in the shallow flood trough along the southern margin of the longitudinal flood bar (fig. 26) provide minimum ages of 12,750 cal. yr B.P. (Beta 252293) and 12,780 cal. yr B.P. (Beta 235569) for the flood sands (table 1, RC-5 and 18) ${ }^{6}$.

Stained sandy pebble-cobble gravels of Delta megafloods are exposed in an abandoned gravel pit in the upland near AMP 1370.4 east of Berry Creek and $-40 \mathrm{~m}$ above the late Donnelly outwash exposed in the roadcut at the Berry Creek crossing (Reger and others, 2008a) (fig. 18; sheet 2). These flood deposits are part of an elongate ridge (flood bar) that trends $254^{\circ}$ azimuth and stands above marshy lowlands on either side, indicating that Delta floods flowed west-southwest in this area. The crudely cross-bedded to massive gravels contain numerous split cobbles and crumbly weathered cobbles with weathering rinds up to $6 \mathrm{~cm}$ thick, indicating that in-situ weathering occurred after gravel deposition, but other clasts appear fairly fresh. The bottoms of many clasts are thinly coated with calcium carbonate. The gravel, with its very coarse sand matrix, is stained dark yellowish brown (10YR4/6). When the pit was first examined in June 1978, a $1.5 \mathrm{~m}$ granitic flood boulder was exposed at an elevation of $-454 \mathrm{~m}$ in the flood gravels there, but has since been moved during pit exploitation and is among several large boulders piled in a corner of the gravel pit (fig. 30). The flood gravels originally buried the nearby granitic knob and its discontinuous, thin grus cover.

${ }^{6}$ Ferrians (1989) dated basal peat overlying sediments of Glacial Lake Atna in the northeastern Copper River basin at 9.4 \pm 0.3 ka (W-714), a minimum date for the lowering of the lake level below the $701 \mathrm{~m}$ threshold in Mentasta Pass and the end of Glacial Lake Atna as the source of jökulhlaups in the Tok and Tanana river drainages. 

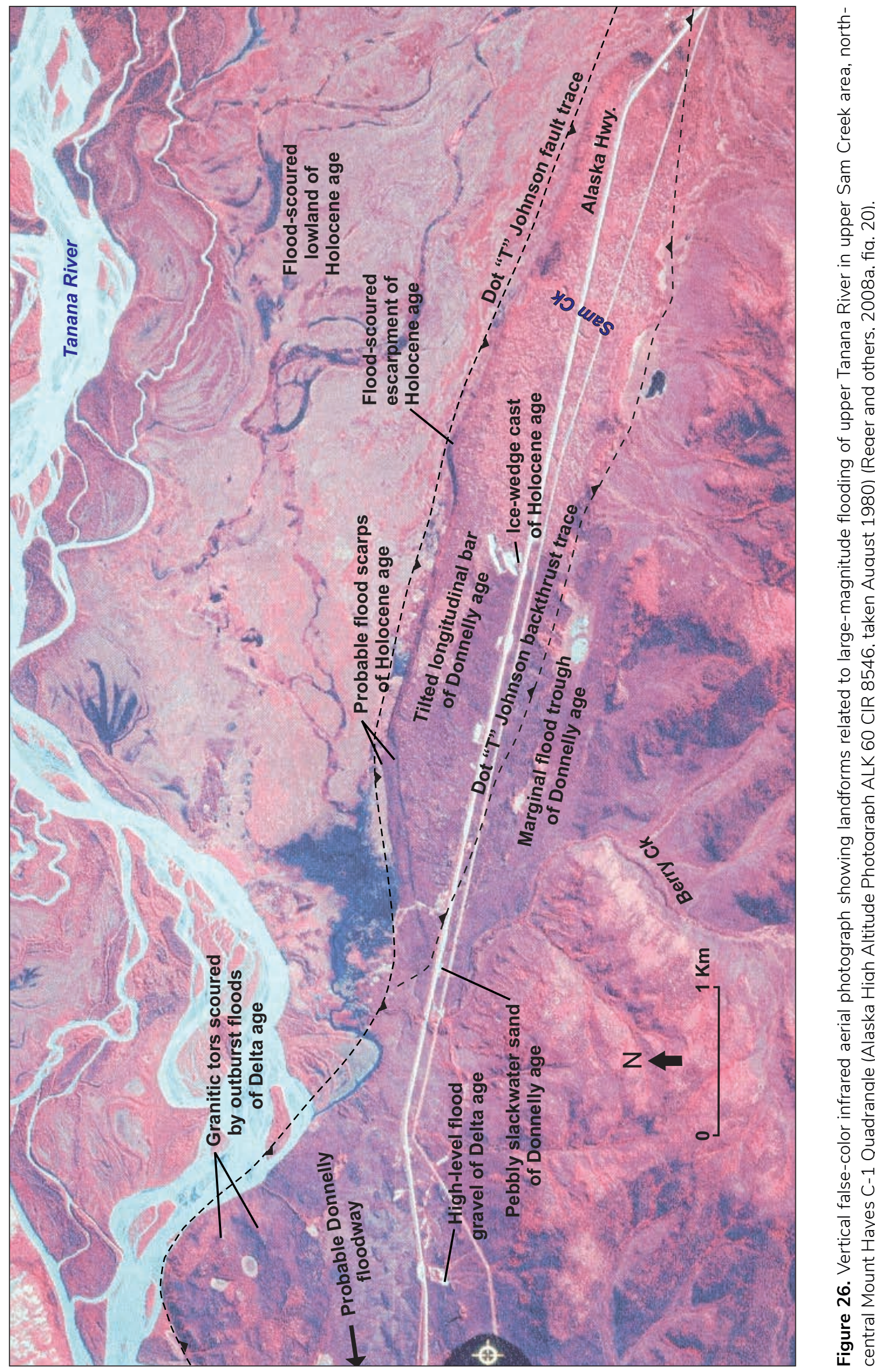


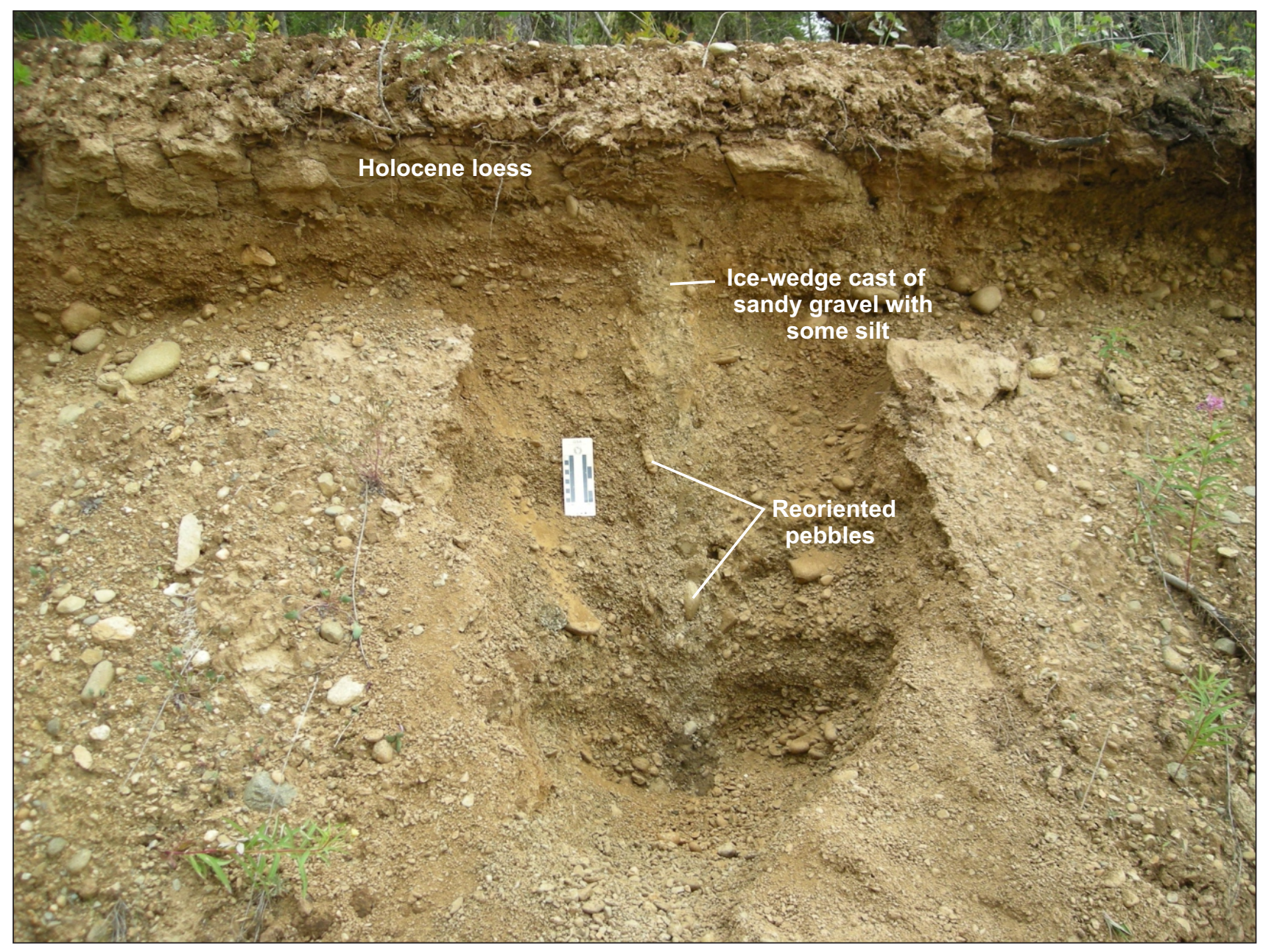

Figure 27. Ice-wedge cast in pebble-cobble gravel of Donnelly age in tilted longitudinal flood bar, north-central Mount Hayes C-1 Quadrangle (Reger and others, 2008a, fig. 21). Scale in inches and centimeters. Photograph taken 7/10/2007.

\section{Extensive escarpments}

Physiographic relations in the Delta Junction area clearly demonstrate that the Clearwater Lake escarpment postdates the early Delta (MIS 6) glaciation and predates the Donnelly (MIS 2) glaciation (fig. 31). That prominent escarpment could be caused by Holocene faulting related to the Northern Foothills Fold and Thrust Belt (Bemis, 2004; Carver and others, 2008a), as implied farther west in the Fairbanks Quadrangle by Péwé and others (1966). However, unequivocal evidence for recent movement on the scarps has not yet been established. Alternatively, we suggest that a series of large-magnitude jökulhlaups cut the Clearwater Lake escarpment, principally during the early Wisconsin (MIS 4) glaciation. To the southeast, the Clearwater Lake escarpment connects with the 34-kmlong Gerstle-Clearwater escarpment, which cuts Delta and Donnelly outwash fans and must be as young as Holocene (sheet 2). A broad, abandoned Holocene floodplain occupies the lowland between the GerstleClearwater escarpment and the Tanana River.

\section{Flood boulders}

Except for very coarse proximal outwash deposits or deep in alluvium exposed in gravel pits (sheets 1-4), few very large boulders were encountered in Tanana River terrace deposits in the Alaska Highway corridor. An interesting exception is on the strath terrace in the Sears-Berry creeks area, where many extraordinarily large granitic flood boulders were excavated during highway construction from fairly thin, sandy, pebble-cobble flood gravels of late Donnelly age (Reger and others, 2008a) (fig. 32; sheet 2). The strath terrace formed when shifts along the active Dot " $T$ " Johnson thrust fault brought bedrock close to the surface (Carver and others, 2008a). The large sizes of the granitic boulders and their subrounded to rounded corners indicate that they were rolled downstream by powerful currents in flood channels as part of the traction bedload. 


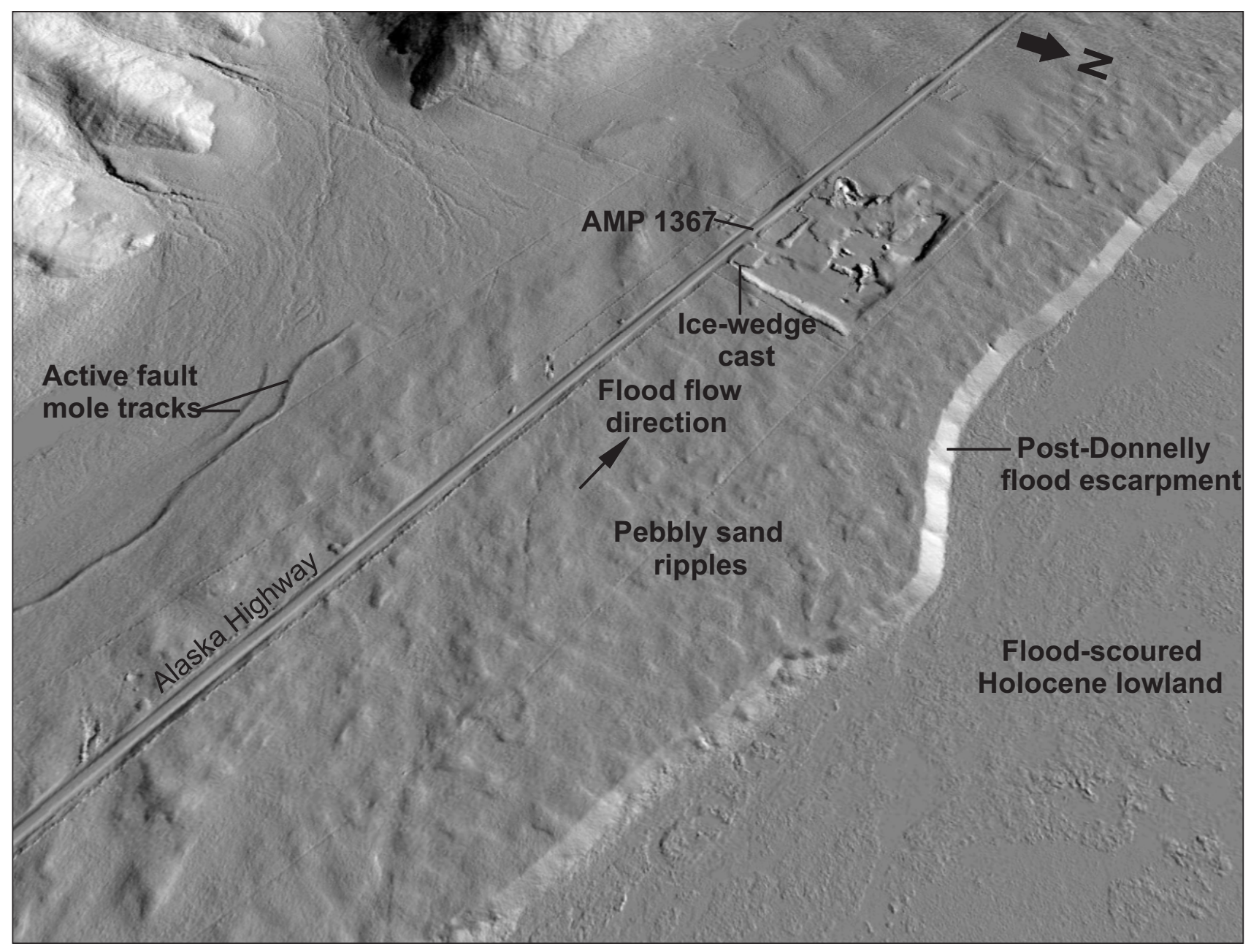

Figure 28. Oblique bare-earth lidar-derived hillshade image showing surface of Donnelly longitudinal flood bar with surface ripples crossed by Alaska Highway and Holocene flood escarpment, north-central Mount Hayes C-1 Quadrangle (Hubbard and others, 2011a).

On the strath terrace, gray, subrounded to rounded granitic flood boulders are commonly mixed with angular to subangular, tabular, brownish granitic blocks and subangular boulders that were probably plucked from a nearby prowshaped bedrock exposure by turbulent floodwaters and incorporated into the bedload (Reger and others, 2008a) (fig. 32). The likely source of the gray boulders is the freshlooking granitic knobs in the lowland north of the Alaska Highway $-2.7 \mathrm{~km}$ east of the strath locality (fig. 26). An initial estimate of velocities during late Donnelly floods in this 3.2-km-wide reach of the Tanana River, based on the intermediate diameters of the five largest boulders in the strath terrace gravels, implies that paleoflood velocities were roughly 5.6 to $6.7 \mathrm{~m} / \mathrm{sec}$, averaging $-6.1 \mathrm{~m} / \mathrm{sec}$ (Reger and others, 2008a). Current velocities that initiated boulder movements would have been much faster, perhaps twice as fast (O’Connor, 1993, p. 57).
The highest flood boulder we found in the Alaska Highway corridor is at $467 \mathrm{~m}$ elevation on a ridge of weathered granitic bedrock $-0.4 \mathrm{~km}$ southwest of the gravel pit described above, where flood gravels of Delta age are exposed (fig. 33; sheet 2). On the ridge, we excavated an unweathered, subangular to subrounded, $61-\mathrm{cm}$-diameter amphibolite boulder from a small, clay-lined pocket in weathered granitic bedrock. The clay beneath the flood boulder was yellowish brown (10YR5/4), a noticeably lighter hue than the dark yellowish brown (10YR4/6) of the grus produced by the weathering of the local granitic bedrock. Present in the clay were a subrounded white quartz dropstone pebble and a subangular amphibolite dropstone pebble. The uniform character of the clay, its different color from the fine-grained weathering products of the local bedrock, and the presence of dropstone pebbles imply that 


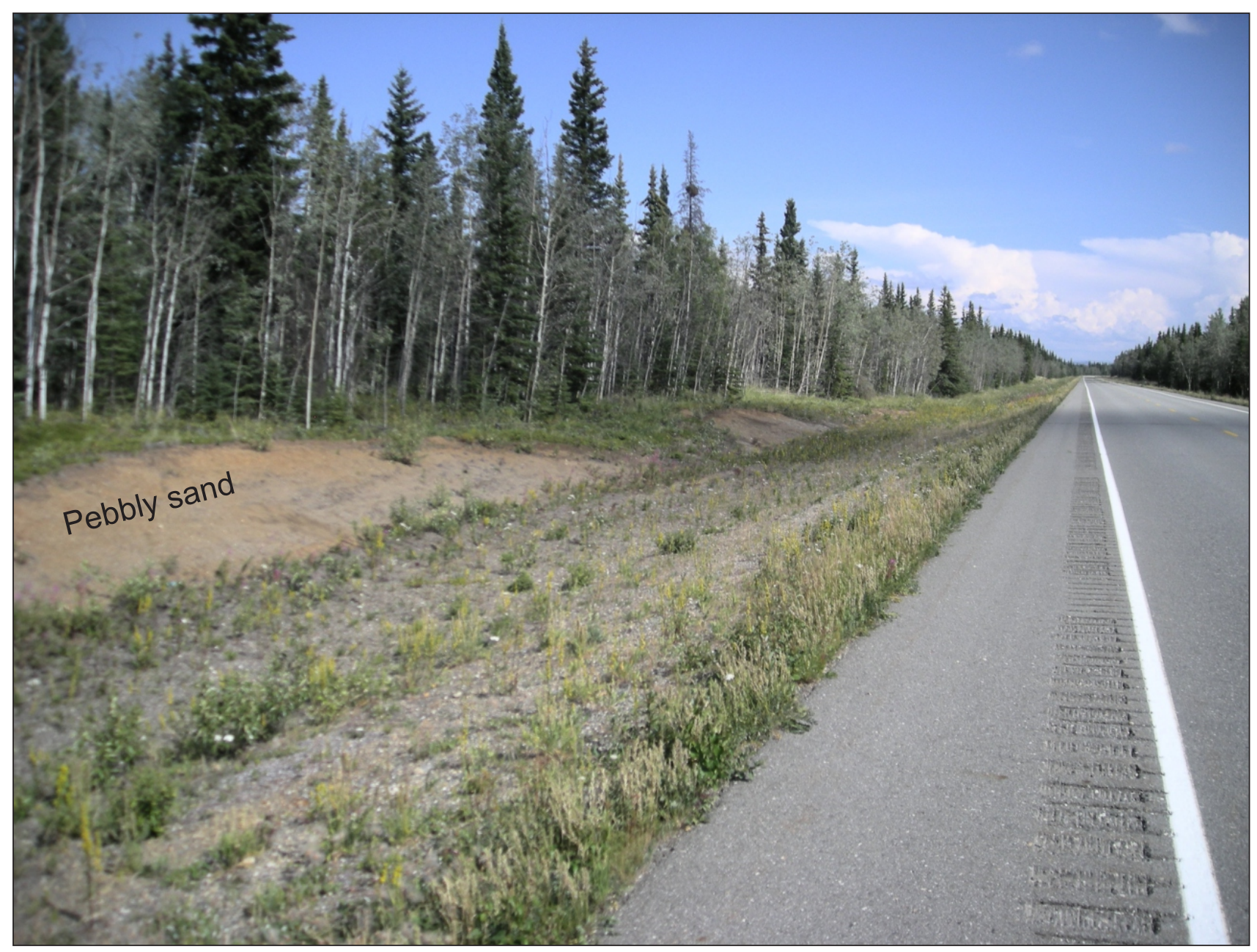

Figure 29. Road cuts along Alaska Highway expose cross sections through pebbly sand waves (flood ripples) on tilted longitudinal flood bar shown in figure 28, north-central Mount Hayes C-1 Quadrangle (Reger and others, 2008a, fig. 22). Photograph taken 7/21/2007.

the clay was deposited during flooding. We suggest that the amphibolite flood boulder was carried to the site as an ice-rafted erratic, and the boulder almost certainly was not retransported downslope from its original depositional site in the pit. Although we do not know the depth of the floodwaters through which it plunged to reach the ground surface, we suggest that its elevation $(467 \mathrm{~m})$ roughly approximates the level reached by outburst flooding in that area during the Delta glaciation, based on methods used to estimate heights of catastrophic flooding from Glacial Lake Missoula in eastern Washington (Baker, 1973, appendix I). Because grus-free knobs of weathered granitic bedrock, which were undoubtedly scoured by floodwaters during the Delta glaciation, reach an elevation of $-477 \mathrm{~m}$ in the middle of the valley to the north (fig. 26; see discussion below), we suggest that massive Delta floods reached an elevation of at least $467 \mathrm{~m}$ in this reach of the Tanana River valley.
Using DEMs combined with functionality in ArcGIS, Grapher, and Excel, we calculated cross-sectional area, wetted perimeter, hydraulic radius, and channel slope in this reach of the Tanana River valley for a paleoflood elevation of $467 \mathrm{~m}$. According to modern hydraulicengineering theory (Henderson, 1966; Kehew, 2006, p. 554-557) and using estimates of the Manning roughness coefficient (0.4) and our calculated values, a Delta-age paleoflood reaching an elevation of $467 \mathrm{~m}$ along profile B-B' (fig. 33) in this 3.2-km-wide valley would have had a discharge of $0.64 \times 10^{6} \mathrm{~m}^{3} / \mathrm{s},\left(10^{2}\right.$ times the average $6.37 \times 10^{3} \mathrm{~m}^{3} / \mathrm{s}$ flow of the modern Yukon River), an average cross-sectional velocity of $5.9 \mathrm{~m} / \mathrm{s}$, and a subcritical flow (Froude number $=0.24)($ table 4$)$. Below the lowest Delta flood bar, aligned, low-relief, grus-free granitic knobs between -437 and $-425 \mathrm{~m}$ elevation were likely scoured by Donnelly jökulhlaups (fig. 32). Along profile B-B' (fig. 33), inferred Donnelly paleoflood discharges 

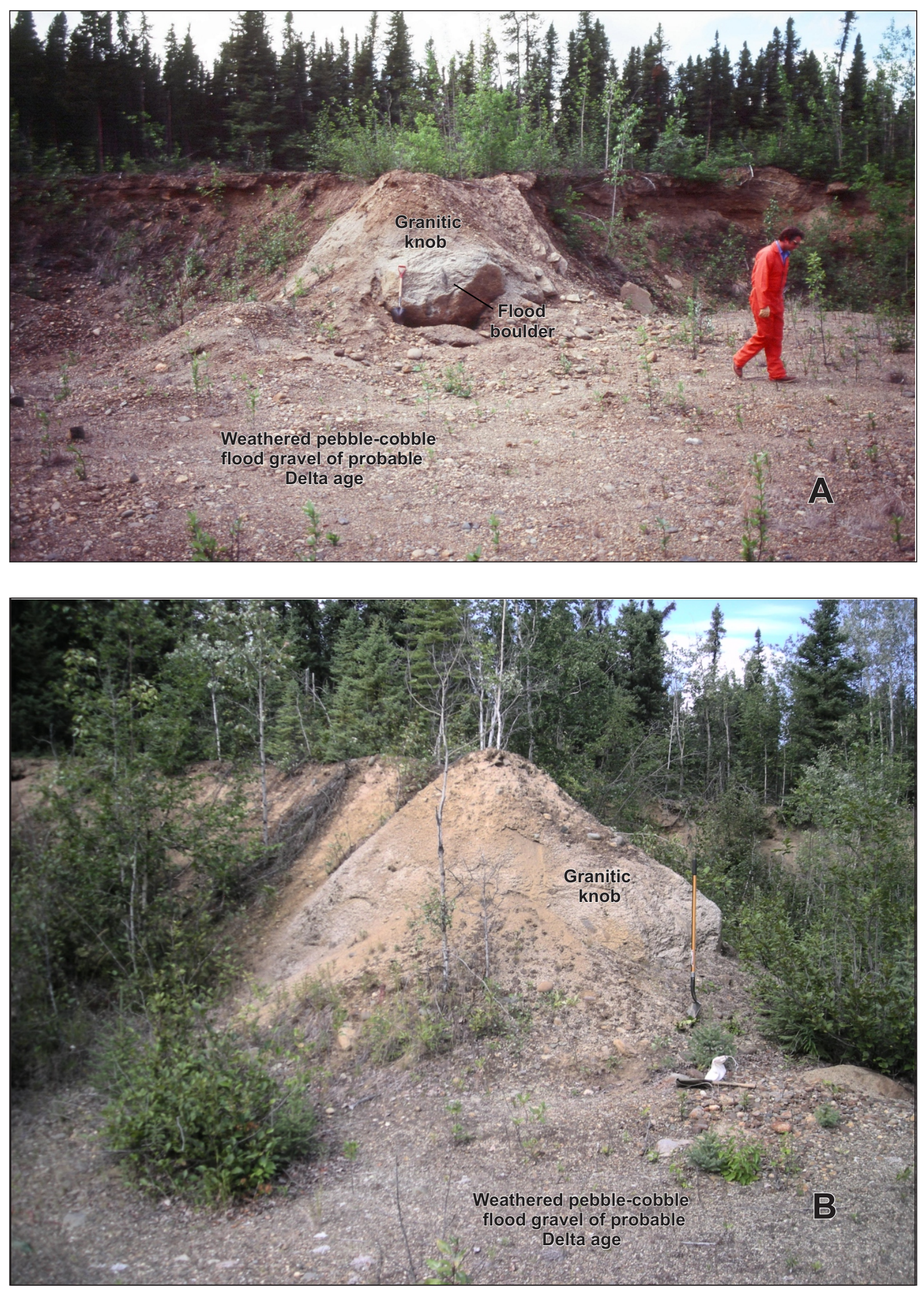

Figure 30. Comparison photographs (A) taken June 1978 of high-level weathered, polymictic Delta-age flood gravel containing 1.5-m granitic flood boulder and (B) taken 8/2/2007 with boulder missing in abandoned gravel pit, northwestern Mount Hayes C-1 Quadrangle (modified from Reger and others, 2008a, fig. 24). 


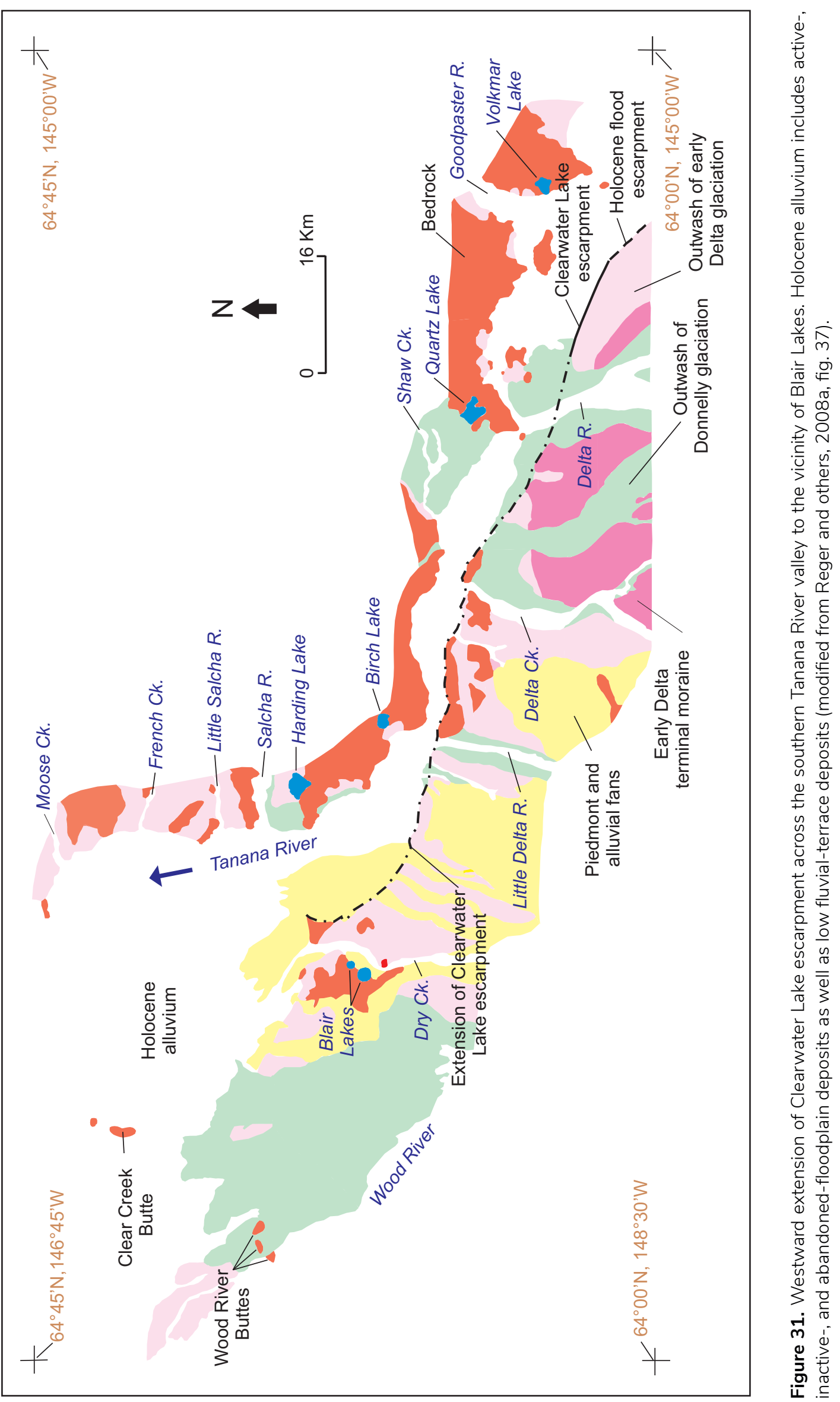


were $0.14-0.06 \times 10^{6} \mathrm{~m}^{3} / \mathrm{s}$, average cross-sectional velocities were $4.0-3.3 \mathrm{~m} / \mathrm{s}$, and flow was subcritical (Froude numbers 0.22 and 0.23 (table 4).

\section{Missing or truncated terminal moraines}

We suggest that missing or truncated terminal moraines of Delta and Donnelly ages at Robertson, Johnson, and Little Gerstle rivers result from the episodic (annual?) passage of massive paleofloods that kept glacier termini trimmed back, preventing blockage of the Tanana River by those glaciers and their expansions into the southern
Yukon-Tanana Upland north of the Tanana River (Reger and Hubbard, 2009; Hubbard and Reger, 2010b).

\section{Flood-modified bedrock exposures}

Bedrock exposures provide evidence of massive Delta and Donnelly flooding in the upper Tanana River valley. Asymmetric granitic tors rise as high as $60 \mathrm{~m}$ above the Tanana River lowland north of AMP 1370.4 along the Alaska Highway east of Berry Creek, where the valley of the Tanana River is $-4 \mathrm{~km}$ wide (figs. 26 and 32). The granitic knobs are associated with flood-scoured bedrock depressions without the grus that is associated

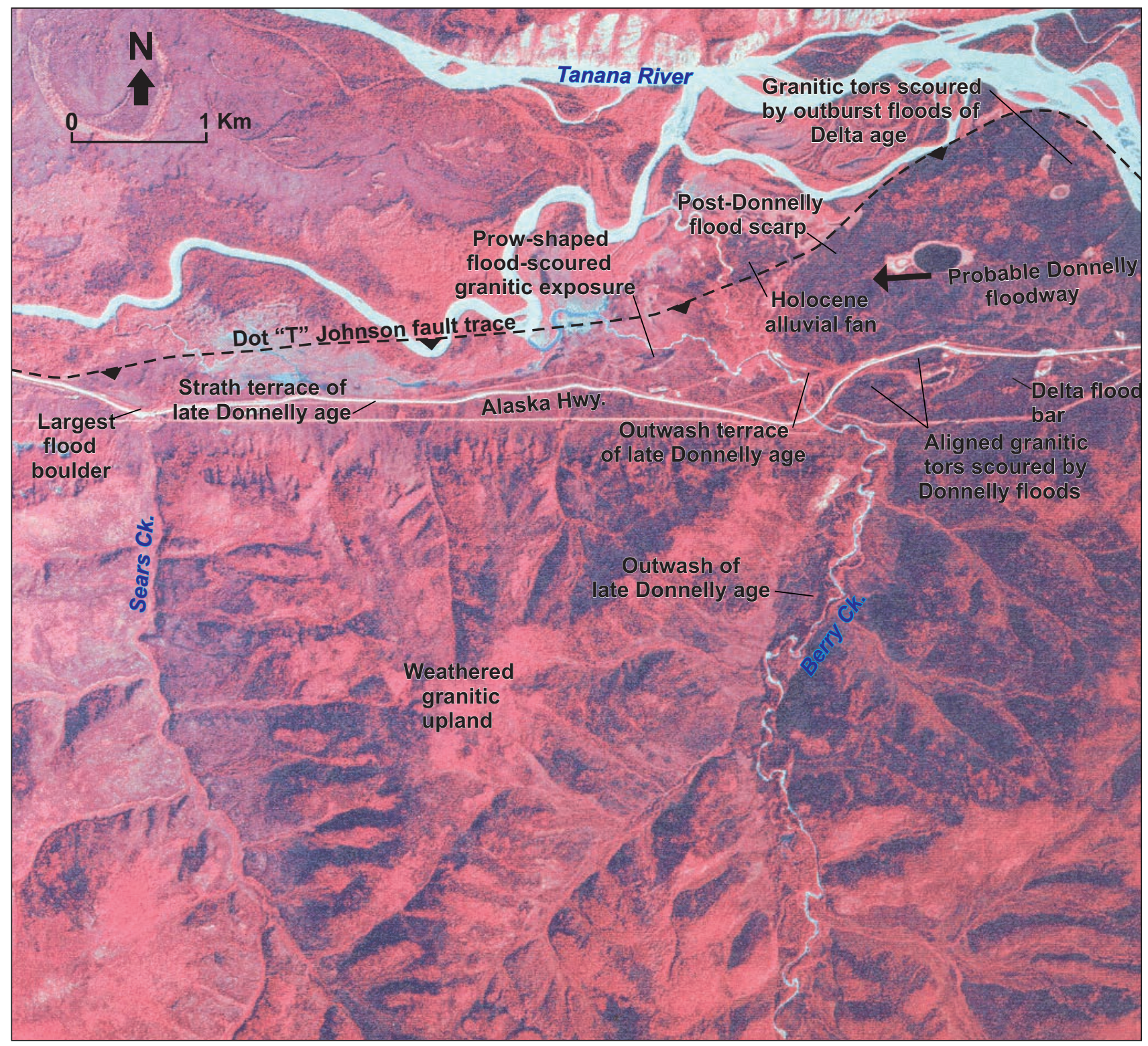

Figure 32. Vertical false-color infrared aerial photograph showing landforms related to large-magnitude Delta and Donnelly flooding and the Dot "T" Johnson fault trace in Sears Creek-Berry Creek area, northwestern Mount Hayes C-1 Quadrangle (Alaska High Altitude Photograph 8544, taken August 1980) (Reger and others, 2008a, fig. 26). 


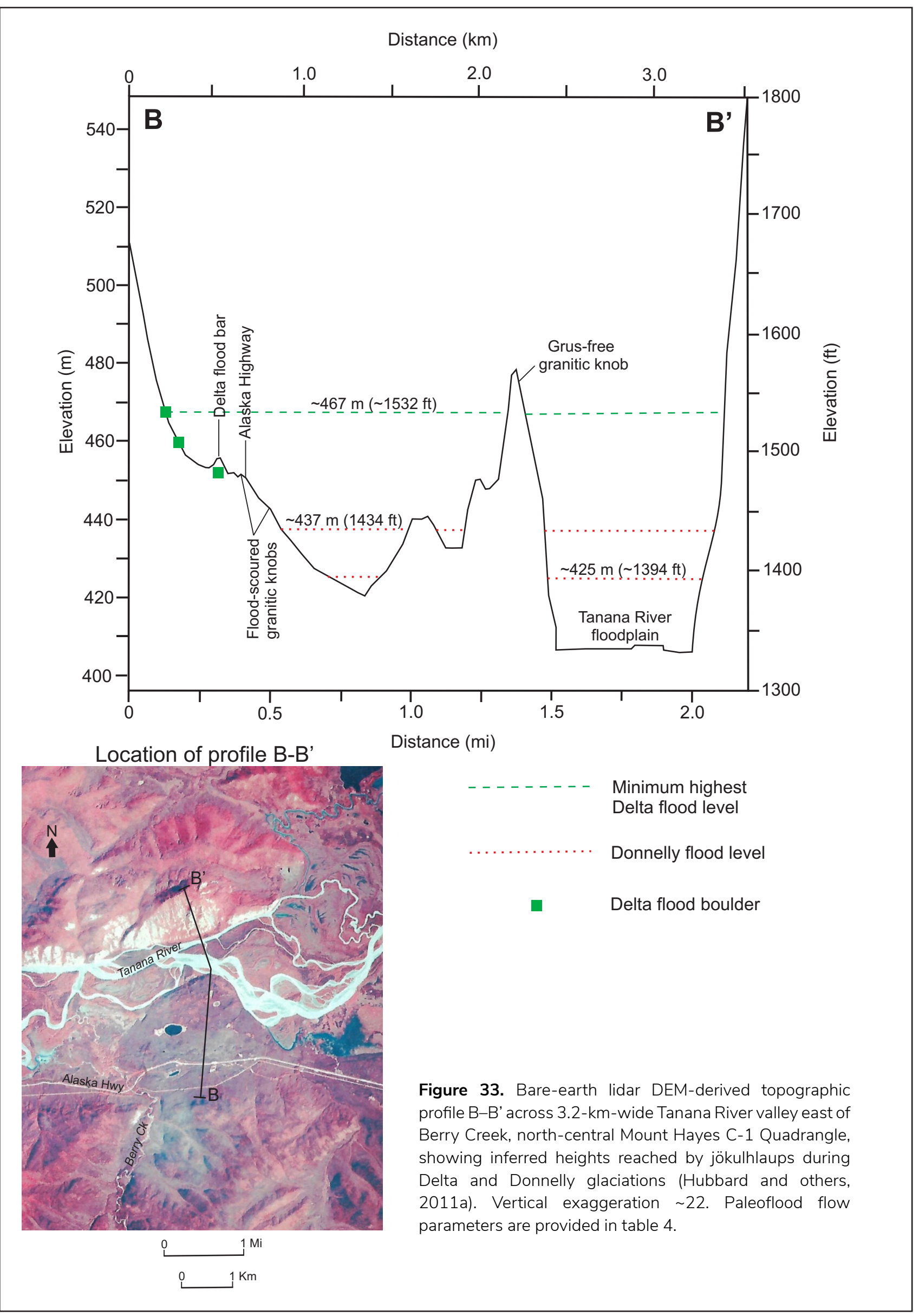


Table 4. Jökulhlaup discharge data derived from lidar, AIRSAR, and IFSAR DEMs using ArcGIS and Grapher for profiles B-B' (fig. 33) and C-C' (fig. 40).

\begin{tabular}{|c|c|c|c|c|c|c|c|}
\hline $\begin{array}{l}\text { Profile flood levels } \\
\qquad(\mathrm{m})\end{array}$ & $\begin{array}{l}\text { Cross- } \\
\text { section } \\
\text { area }\left(\mathbf{m}^{2}\right)\end{array}$ & $\begin{array}{c}\text { Channel } \\
\text { slope } \\
(\%)\end{array}$ & $\begin{array}{l}\text { Manning } \\
\text { roughness } \\
\text { coefficient } \\
\text { (n) }\end{array}$ & $\begin{array}{l}\text { Average } \\
\text { cross- } \\
\text { sectional } \\
\text { velocity }{ }^{1} \\
(\mathrm{~m} / \mathrm{s})\end{array}$ & $\begin{array}{c}\text { Discharge } \\
\left(\mathrm{m}^{3} \times 10^{6} / \mathrm{s}\right)^{2}\end{array}$ & $\begin{array}{l}\text { Depth } \\
(\mathrm{m})\end{array}$ & $\begin{array}{l}\text { Froude } \\
\text { number }^{3}\end{array}$ \\
\hline $\begin{array}{l}\text { B-B' } 467 \\
\text { (Minimum highest Delta) }\end{array}$ & $10.8 \times 10^{4}$ & 0.004 & 0.04 & 5.9 & 0.64 & 62 & 0.24 \\
\hline $\begin{array}{l}\text { B-B' } 437 \\
\text { (Maximum Donnelly) }\end{array}$ & $3.5 \times 10^{4}$ & 0.004 & 0.04 & 4.0 & .14 & 32 & 0.22 \\
\hline $\begin{array}{l}\text { B-B' } 425 \\
\text { (Lower Donnelly) }\end{array}$ & $1.7 \times 10^{4}$ & 0.004 & 0.04 & 3.2 & 0.06 & 19 & 0.23 \\
\hline $\begin{array}{l}\text { C-C' }(753 / 701) \\
\text { (maximum/threshold) }\end{array}$ & $9.4 \times 10^{4}$ & 0.004 & 0.04 & 21.0 & 2.0 & 52 & 0.94 \\
\hline
\end{tabular}

${ }^{1}$ Average cross-sectional velocity, $\left.\mathrm{V}^{*}=\left[\left(\mathrm{R}^{2 / 3}\right)\left(\mathrm{S}^{1 / 2}\right)\right\} 0\right]$, where $\mathrm{R}=$ hydraulic radius in meters, $\mathrm{S}=$ channel slope in meters/meter, and $\mathrm{n}=\mathrm{Manning}$ channel roughness coefficient, which is assumed to be 0.04 and ignores possible blockages of the flood channel by ice jams. Grapher 9 and ArcGIS interpolation tools were used to derive channel slope and hydralic radius, $R=A / P$, where $A=$ cross-section area and $P=$ wetted perimeter.

${ }^{2}$ Discharge, $Q=V^{*} / A$, where $V^{*}=$ average cross-sectional velocity and $P=$ wetted perimeter (Henderson, 1966).

${ }^{3}$ Froude number, $\mathrm{Fr}=\mathrm{v}\left[1 /(\mathrm{gD})^{1 / 2}\right]$, where $\mathrm{v}=$ stream velocity, $\mathrm{g}=$ gravity acceleration, and $\mathrm{D}=$ depth of flow (Kehew, 2006).

with weathered granitic bedrock outside flood areas in the corridor. Instead, open spaces are present between jumbled granitic joint blocks, which are as long as $9 \mathrm{~m}$ and as thick as $2.1 \mathrm{~m}$, and loess-capped sand dunes bearing post-Donnelly soil profiles cover lower slopes (Reger and others, 2008a). Block surfaces feel rough, and feldspar crystals stand in relief up to $7 \mathrm{~cm}$ on weathered surfaces. In contrast, in the vicinity of the Alaska Highway across the lowland to the south is a swarm of low, streamlined granitic knobs that appear relatively fresh. Those bedrock knobs stand 2.4 to $3 \mathrm{~m}$ high and are oriented at $-225^{\circ}$ azimuth, about $45^{\circ}$ from the general orientation of the Tanana River valley at this location. The tors have little grus surrounding them, although there are shallow weathering pans on upper surfaces, and small knobs and mafic inclusions 7.6 to $10.2 \mathrm{~cm}$ across stand 1.5 to $3.2 \mathrm{~cm}$ above the rock surfaces, indicating that grus was formerly present (Reger and others, 2008a). Because of their streamlined morphologies and lack of grus, we interpret these relatively fresh rock knobs as evidence of inundation and scouring by jökulhlaups during the Donnelly glaciation (figs. 26 and 32).

Elsewhere downriver, we also interpret grus-free, prowshaped, riverside granitic bedrock exposures with bows pointing upriver as evidence of major flooding (fig. 34).

\section{Proposed Jökulhlaup flood model}

A viable model for massive paleoflooding in the upper Tanana River drainage must explain three general conditions:
1. A voluminous source of meltwater for massive paleofloods,

2. A mechanism to impound and then release the paleofloods, and

3. The origin, age, and significance of torrentrelated landforms along the flood course.

Field evidence clearly demonstrates that Glacial Lake Atna in the northeastern Copper River basin was the dominant source of colossal paleofloods in the upper Tanana River drainage during the Donnelly glaciation. We recognize no surface evidence for floods of this magnitude upstream of the Tok expansion fan in the Tanana River drainage. Paleofloods from Glacial Lake Atna were likely supplemented by outbursts from potentially dozens of small, glacially impounded meltwater lakes along their journeys through the eastern Alaska Range and down the upper Tanana River. For example, former outburst channels are probably associated with Donnelly terminal moraines of the Johnson River and Robertson River lobes (fig. 16; sheets 2 and 3).

During the last major glaciation, southern drainages from the Copper River basin became blocked by advancing valley glaciers in the Chugach Mountains, and an extensive meltwater body, Glacial Lake Atna, accumulated in the Copper River lowland (Ferrians and Schmoll, 1957; Ferrians and others, 1983). In the northeastern Copper River basin, the waters of Glacial Lake Atna rose to elevations of -745 to $-750 \mathrm{~m}$ during 


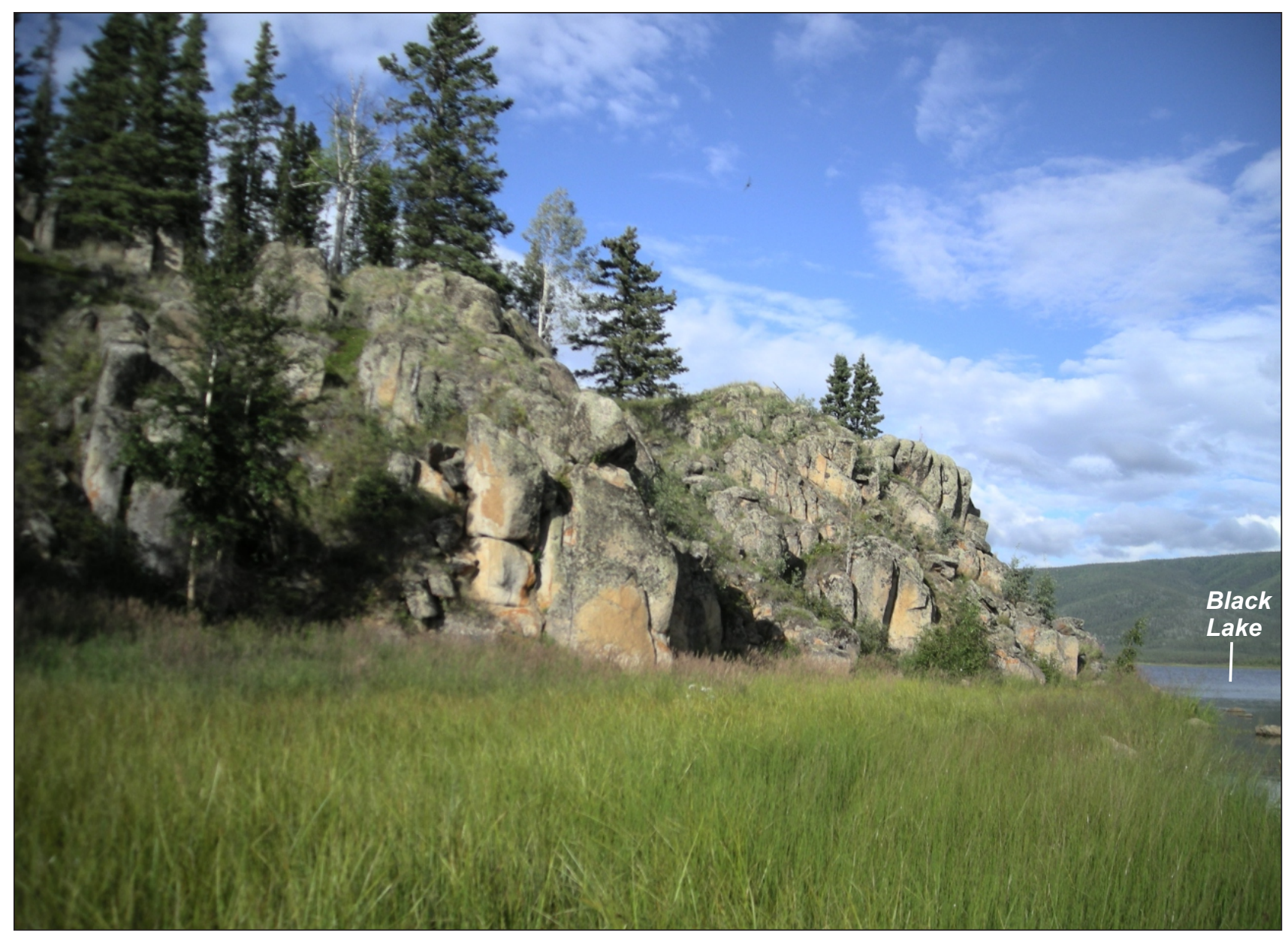

Figure 34. View northward of a 15-m-high, prow-shaped granitic outcrop washed clean of former grus cover by largemagnitude paleofloods in Black Lake area, southeastern Mount Hayes D-2 Quadrangle (Reger and others, 2008a, fig. 34). Photograph taken 7/23/2007.

the late Wisconsin glaciation (Schmoll, 1984; Ferrians, 1989; Williams, 1989). Interpretation of aerial photographs indicates that ice from the northeastern Wrangell Mountains floated northward across Glacial Lake Atna and reached the southern flank of the Alaska Range in the vicinity of Slana, where it deposited the Cobb Lakes moraine at elevations up to $-753 \mathrm{~m}$ and advanced up the lower Slana River valley (figs. 35 and 36).

Schmoll (1984) collected a small piece of driftwood from bedded lake-bottom sands at $-670 \mathrm{~m}$ elevation in the bluff at Slana, and obtained a radiocarbon age of 17,600 \pm 400 RC yr B.P. $(21,300$ cal. yr B.P.) (W-1 134) (table 1, RC-6), which he claimed probably dates the $753 \mathrm{~m}$ and some lower levels of Glacial Lake Atna. We collected a small piece of driftwood at -729 m elevation in the same lake-bottom sands $-3.2 \mathrm{~km}$ west of Slana and obtained a radiocarbon age of $>43,500 \mathrm{RC}$ yr B.P. $(>46,640 \mathrm{cal}$. yr B.P.) (Beta 303537) (fig. 36; table 1, RC-7), implying that driftwood dates are unreliable because their ultimate prov- enance is unknown. Nonetheless, Schmoll's radiocarbon date is consistent with the physiographic and stratigraphic evidence for the age of Glacial Lake Atna and represents the best estimate of its age in the northeastern Copper River basin at this time.

Till exposed in extensive road cuts in the lower Slana River valley is very coarse and granular. Counts of pebbles indicate that it is primarily composed of Alaska Range rock types. In the Slana area, 17-20 percent of the pebbles counted are vesicular andesite volcanics from the Wrangell Mountains, and the content of Wrangell Mountains clasts in inventoried pebble collections decreases upvalley to 3 percent at the moraine terminus near the Tok Cutoff crossing of the Slana River. Counts at the mouths of stream tributaries from the Alaska Range to the north demonstrate that local input dominated by Alaska Range lithologies contributes significantly to the decrease of Wrangell Mountain lithologies in the dominantly gla- 


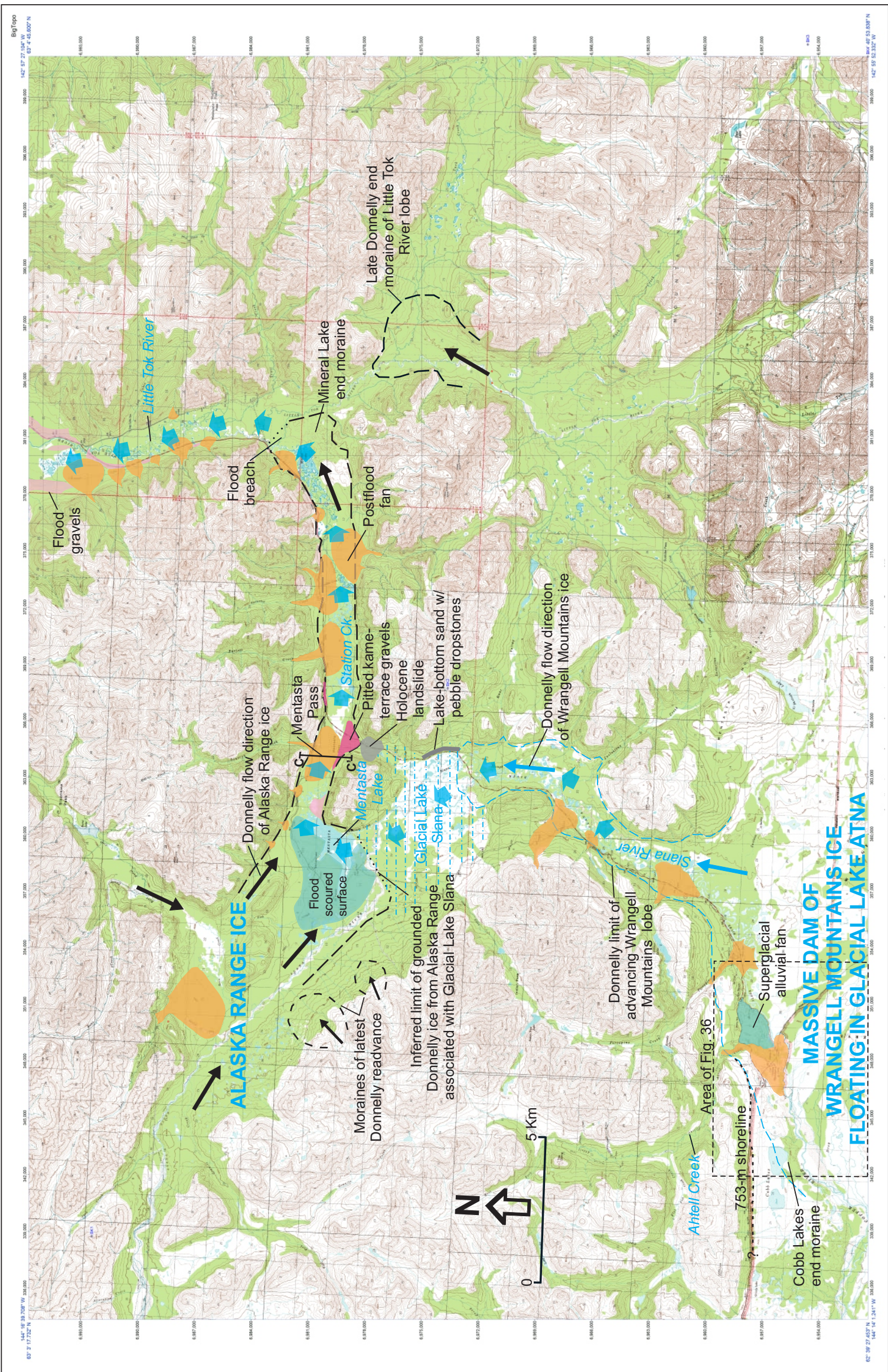

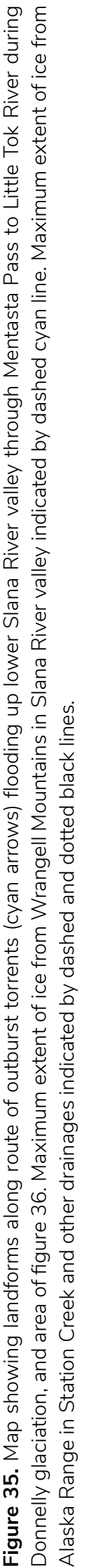




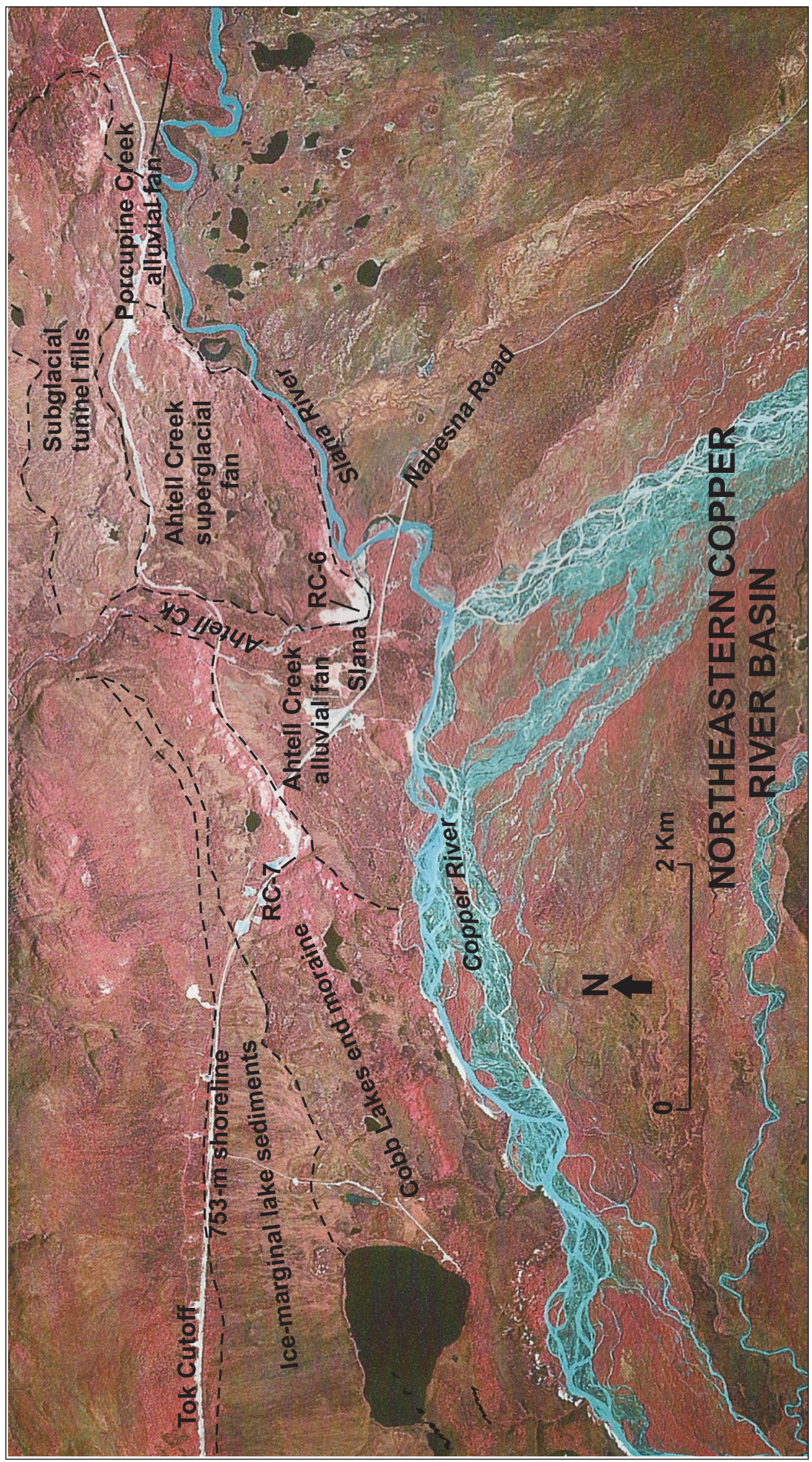

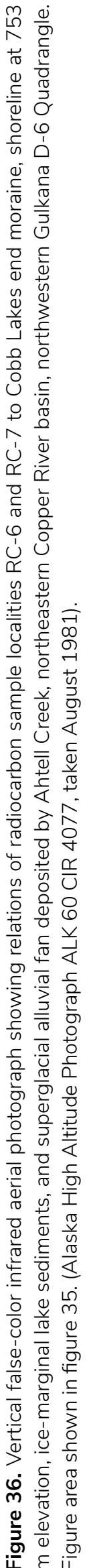


ciofluvial morainal deposits. However, clast roundness and average size also decrease upvalley in the exposures.

At the mouth of the Slana River valley, Ahtell Creek deposited a superglacial fan composed of Alaska Range rock types on the former glacier surface. The fan survives today as a deeply pitted gravel table at $-732 \mathrm{~m}$ elevation in the vicinity of Tok milepost (TMP) 62.07. On the north side of the fan, a complex of coarse-grained tunnel fillings (eskers) locates where Ahtell Creek formerly became subglacial and contributed coarse alluvium to the Donnelly lateral moraine. The distribution of Donnelly moraines in the lower Slana River valley and lake-bottom sands overlying end-moraine deposits in the terminal zone of the former glacial tongue near TMP 75.5 demonstrate that Wrangell Mountains ice terminated in a meltwater lake, informally called Glacial Lake Slana, which formerly occupied the middle Slana River lowland (fig. 35) ${ }^{8}$. A small area of flood-scoured moraine at the southeastern corner of Lake Mentasta and nearby pitted outwash from Alaska Range ice in the northwestern Slana River lowland are evidence that ice from the Alaska Range also fronted in Glacial Lake Slana (fig. 35).

We propose that as meltwaters accumulated in Glacial Lakes Atna and Slana and the lake levels rose, the ice plug in the lower Slana River valley became unstable and began leaking meltwaters of Glacial Lake Atna, which flowed northward down the hydraulic gradient into Glacial Lake Slana, inundated the lowland north and west of Mentasta Lake ${ }^{9}$, overtopped the Mentasta Pass threshold, and poured down the Station Creek valley through the breached Mineral Lake end moraine into the Little Tok River valley (figs. 35 and 37). Floodwaters probably also flowed through the narrow gap near TMP 79.1, but the evidence is obscured by Holocene landslides (fig. 35). At the north end of the gap near TMP 79.7, the pitted surface of kame-terrace gravels with $\sim 20$ percent vesicular andesite clasts at $-732 \mathrm{~m}$ elevation (fig. 38) results from the deposition of flood gravels on glacial ice that remained near Mentasta Pass in the western Station Creek valley (fig. 37, T2). Compared to the $701 \mathrm{~m}$ Donnelly flood threshold in Mentasta Pass, the elevation of the pitted flood gravels implies that the former glacier was $-30 \mathrm{~m}$ thick there when the kame-terrace gravels were deposited along the glacier margin ${ }^{10}$.

We question Schmoll's (1984) contention that the glacier in Station Creek valley was breached subglacially during flooding. Our flood model for the Mentasta PassStation Creek area is based on the northern roadcut exposure at TMP 82.9 (fig. 39), which displays unweathered till with Alaska Range erratics overlain by $1-2 \mathrm{~m}$ of very coarse, clean, massive sand with scattered polymictic pebbles. We suggest that early flooding across the glacier initially present in Mentasta Pass was fairly shallow and flowed along the margins of the valley glacier, carrying sand in suspension ${ }^{11}$. As ice was progressively removed from the pass during subsequent flooding, jökulhlaup volumes and velocities increased with the expanding cross section at the flood threshold to the degree that pebblecobble gravels were transported and $-11 \mathrm{~m}$ of pebble-rich flood gravels with numerous cobbles up to $-25 \mathrm{~cm}$ diameter were deposited above the sand in the lower roadcut exposure (fig. 39). Pebble counts demonstrate that the clasts in the flood gravels there are composed of -78 percent Alaska Range and -22 percent Wrangell Mountain lithologies.

Our estimate of peak paleoflow parameters across the Mentasta Pass threshold during the largest Donnelly jökulhlaups after removal of the glacier in Mentasta Pass is derived from the trapezoidal cross section in the IFSAR $^{12}$ DEM across Mentasta Pass (fig. 40). For this model, the elevation of peak Donnelly megaflooding is placed at $753 \mathrm{~m}$, the elevation of the Donnelly shoreline at Slana (fig. 36), and the decantation threshold is $701 \mathrm{~m}$ elevation ${ }^{10}$. Average maximum paleoflood velocity and discharge through Mentasta Pass were modeled using the Manning equations (Kehew, 2006) at $21.0 \mathrm{~m} / \mathrm{s}$ and $2.0 \times 10^{6} \mathrm{~m}^{3} / \mathrm{s}$, respectively (table 4). The largest paleofloods had near-critical flows (Froude number $=0.94)$. We conclude that our model velocity and discharge values probably overestimate the actual jökulhlaup values because the hydraulic-engineering methodology assumes that flow velocities were uniform across the flood channel, which is clearly not the case in natural

\footnotetext{
${ }^{7}$ Mileposts along the Tok Cutoff decrease southwestward toward TMP 0 at Gakona Junction.

${ }^{8}$ Roadside lake-bottom sands with scattered pebble dropstones between TMP 76.9 and TMP 77.5 demonstrate that the former lake rose to at least $704 \mathrm{~m}$ elevation and bergs of glacial ice carrying exotic vesicular andesite erratics floated in it (fig. 37, T0).

${ }^{9}$ Vesicular andesite dropstones scattered on this surface and a subdued relief are evidence for the passage of paleofloods across this surface (fig. 37, T1).

${ }^{10}$ The elevation of Mentasta Pass during Donnelly jökulhlaups is an approximation. Orth (1971, p. 635) used an elevation of $695 \mathrm{~m}$ for the pass elevation. Our estimate of a Donnelly threshold elevation of $701 \mathrm{~m}$ is based on the lowest elevation along the IFSAR profile across Mentasta Pass. Wiedmer and others (2010) also assumed a flood-threshold elevation of $701 \mathrm{~m}$, using similar satellite-based techniques.

${ }^{11}$ During early jökulhlaup flooding from Strandline Lake in 1982, floodwaters followed the margin of the blocking glacier, Triumvirate Glacier, before flowing under the ice downglacier through a complex tunnel system (Sturm and Benson, 1985).

${ }^{12}$ Interferometric synthetic aperture radar.
} 


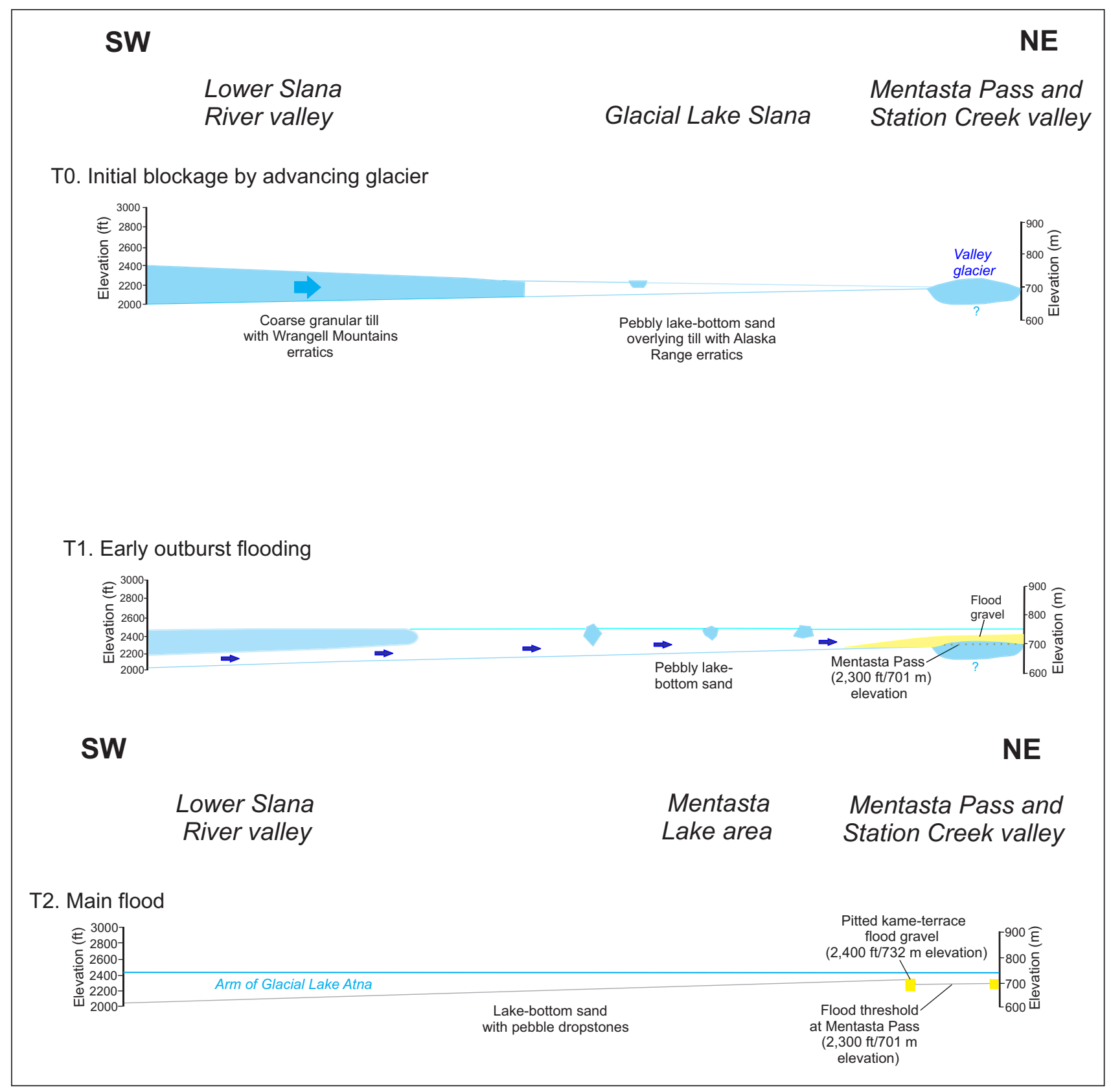

Figure 37. Proposed jökulhlaup flood model for lower Slana River-Station Creek drainages, northwestern Nabesna Quadrangle. Progress through time indicated: T0 = initial glacier invasion and damming of lower Slana River valley; T1 = early outburst flooding; T2 = main flood phase. Vertical exaggeration $\sim 15 X$.

floods, where channel dimensions and slopes are nonuniform and flood flows pulse (Baker, 1973; O’Connor and Webb, 1988). Our estimated discharge is one to two orders of magnitude greater than the maximum discharge $\left(0.07-0.1 \times 10^{6} \mathrm{~m}^{3} / \mathrm{s}\right)$ predicted by Wiedmer and others (2010), which was based on a pre-flood lake elevation of $747 \mathrm{~m}$ and a threshold elevation at Mentasta Pass of $701 \mathrm{~m}$. Comparison of the average maximum velocity with the Hjulstrom curve (Kehew, 2006, fig. 14.17) implies that peak paleofloods considerably exceeded the flows necessary to initiate and sustain transport of the flood gravels observed in the Tok River drainage, including the massive Tok expansion fan.

Initially, decantations from Glacial Lake Slana were water floods that incorporated valley-fill deposits along the flood course and morphed into hyperconcentrated flows. Ultimately, the water torrents removed or scoured the northern half of the Mineral Lake end moraine, leaving a 2.7-km-wide flood breach providing unimpeded access to the upper Tok 


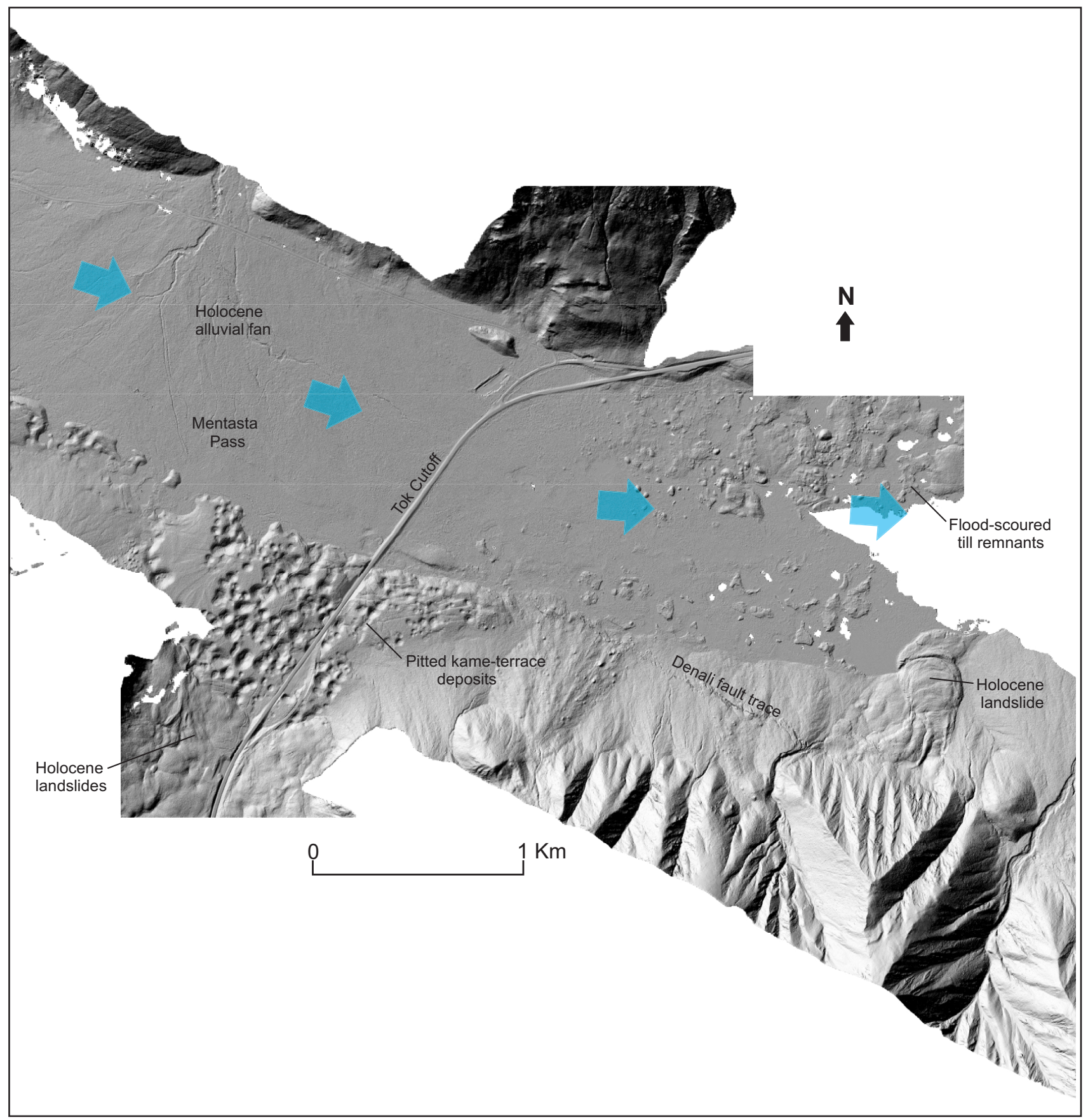

Figure 38. Bare-earth lidar-derived hillshade scene showing pitted kame-terrace deposits and flood-scoured glacial drift in main jökulhlaup path (cyan arrows) near Mentasta Pass, northeastern Nabesna D-6 Quadrangle (UNAVCO, 2008).

River drainage. Flood- and thermokarst-modified knobs of glacial drift remain on the valley floor between Mentasta Lake and the Mineral Lake moraine (fig. 41). The large alluvial fans and steep colluvial-alluvial fans at the mouths of tributary valleys in Station Creek and Little Tok River valleys represent postflood Holocene deposition (fig. 35).
In the Little Tok River valley, exposures in roadcuts and gravel pits reveal terrace fills composed of clast- and matrix-supported pebble gravels ${ }^{13}$, depending on the content of medium to coarse sand in the matrix (estimated to vary from 10 to 30 percent). Silt is present in trace amounts. Fresh exposures indicate that flood gravels in

\footnotetext{
${ }^{13}$ Paleoflood gravels in the Tok River drainage are dominantly composed of Alaska Range lithologies. They incorporate previous valley fill materials, debris from the flood breach through the Mineral Lake end moraine, and contributions from several tributaries along the flood course. Numerous pebble counts down the flood path indicate that vesicular andesite erratics from the Wrangell Mountains decrease from minor to trace components ( 20 to $\sim 3$ percent).
} 
terrace fills are massive to crudely bedded, with discrete units ranging in thickness from 38 to $>125 \mathrm{~cm}$ (fig. 42). Polymictic pebbles and cobbles vary in shape from subangular to rounded and are rarely frost split. Imbrication is weak to nonexistent. Small, subrounded to rounded boulders are rare to scattered and reach a maximum diameter of $-38 \mathrm{~cm}$. Flood gravels contain $10-12$ percent vesicular volcanic clasts. These terrace deposits could have been part of the traction load deposited by watery flood pulses or by hyperconcentrated flood flows in this transition zone from water-rich to sediment-rich flood pulses. Clear evidence of hyperconcentrated flood flows is not recognized in the Tok River drainage above the Tok expansion fan.

The passage of Donnelly paleofloods down the Little Tok River and Tok River valleys to the Tok expansion fan is documented by remnants of gravel expansion fans and extensive erosion scarps along the lower sides of the Tok River valley (fig. 20; Sicard and others, 2017). The main expansion fan in the Little Tok River valley is represented by the upper of two fill terraces, with a tread $-12 \mathrm{~m}$ above the abandoned floodplain of the Little Tok River. The lower fill terrace, at $6 \mathrm{~m}$ above the abandoned floodplain of the Little Tok River, appears to be outwash from the postflood (late Donnelly) end moraine upvalley of the Mineral Lake moraine in the Little Tok River valley (fig. 35).

Carver and others (2010) demonstrated that the long discontinuous scarps along the lower walls of the Tok River valley are not fault scarps, but represent flood scarps as young as Holocene. In a trench in the upper Tok River valley (fig. 20) the northwestern scarp has a minimum age of 1,500 $\pm 40 \mathrm{RC}$ yr B.P. (1,410 cal. yr B.P.) (Beta 252313) (table 1, RC-8), as determined by the radiocarbon age of a charred detrital twig in loess beneath debris flows that buried the flood scarp. Scattered patches of polymictic

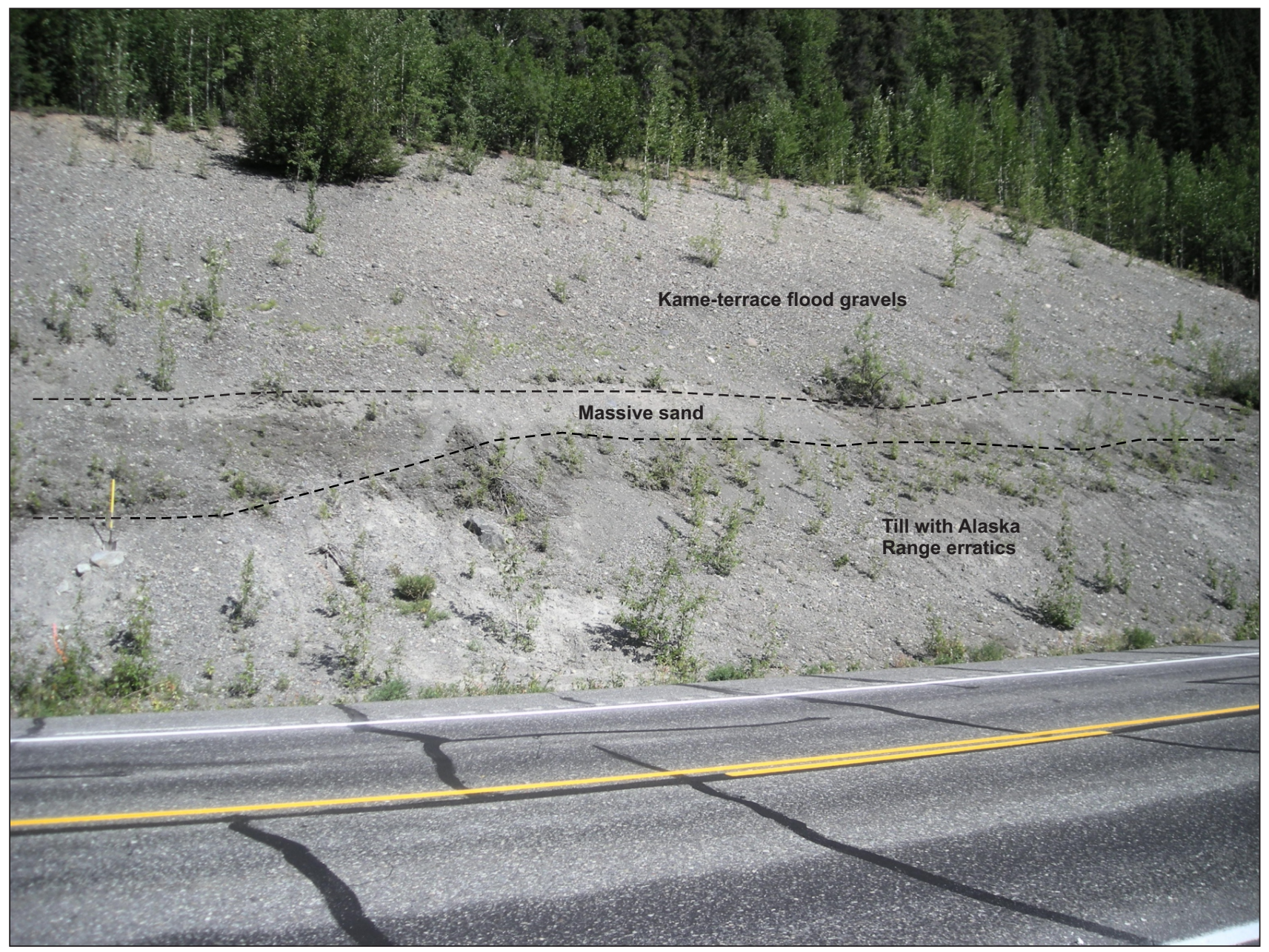

Figure 39. Roadcut exposure of kame-terrace flood gravels overlying massive sand above Donnelly till with Alaska Range erratics, TMP 82.9, northeastern Nabesna D-6 Quadrangle. Shovel handle at center left is $1 \mathrm{~m}$ long. Photograph taken $7 / 21 / 2009$. 
pebble-cobble gravel in roadcuts through the linear Tok River valley could be flood gravels or displaced granular till of Delta lateral moraines.

\section{EOLIAN AND RELATED DEPOSITS EAST OF TOK \\ Eolian sand}

During the penultimate and last major glaciations, strong, cold, dense katabatic winds swept downslope across outwash fans and aprons at the mouths of major tributary valleys all across the northern flank of the eastern Alaska Range, entraining and transporting sand and silt into nearby lowlands and the southeastern Yukon-Tanana Upland (Thorson and Bender, 1985; Muhs and others, 2003; Muhs and Budahn, 2006) (fig. 43).

Across the Tanana River northeast of the Tok River alluvial fan is the Tetlin Junction dune field (Carrara, 2006;
Reger and others, 2011) (fig. 44; sheet 4). The position of this dune field relative to the broad fan indicates that the eolian sands in the dune field were deposited by strong winds sweeping northeastward out of the Tok River valley across the Tok River alluvial fan and the Tanana River floodplain. The orientations of parabolic sand dunes west of the Taylor Highway demonstrate that winds have most recently blown across the dune field from the south and southeast (Carrara, 2006). The south wall of the deep valley of middle Porcupine Creek along the northern edge of the dune field exposes at least $60 \mathrm{~m}$ of eolian sand. The maximum age of the Tetlin Junction dune field is provided by Carrara (2006), who dated willow fragments from near the top of a lacustrine sand beneath the eolian sand at 41,880 $\pm 470 \mathrm{RC}$ yr B.P. $(45,240 \mathrm{cal}$. yr B.P.) (Beta-171226) (sheet 4; table 1, RC-9), indicating that the dune field began accumulating during MIS

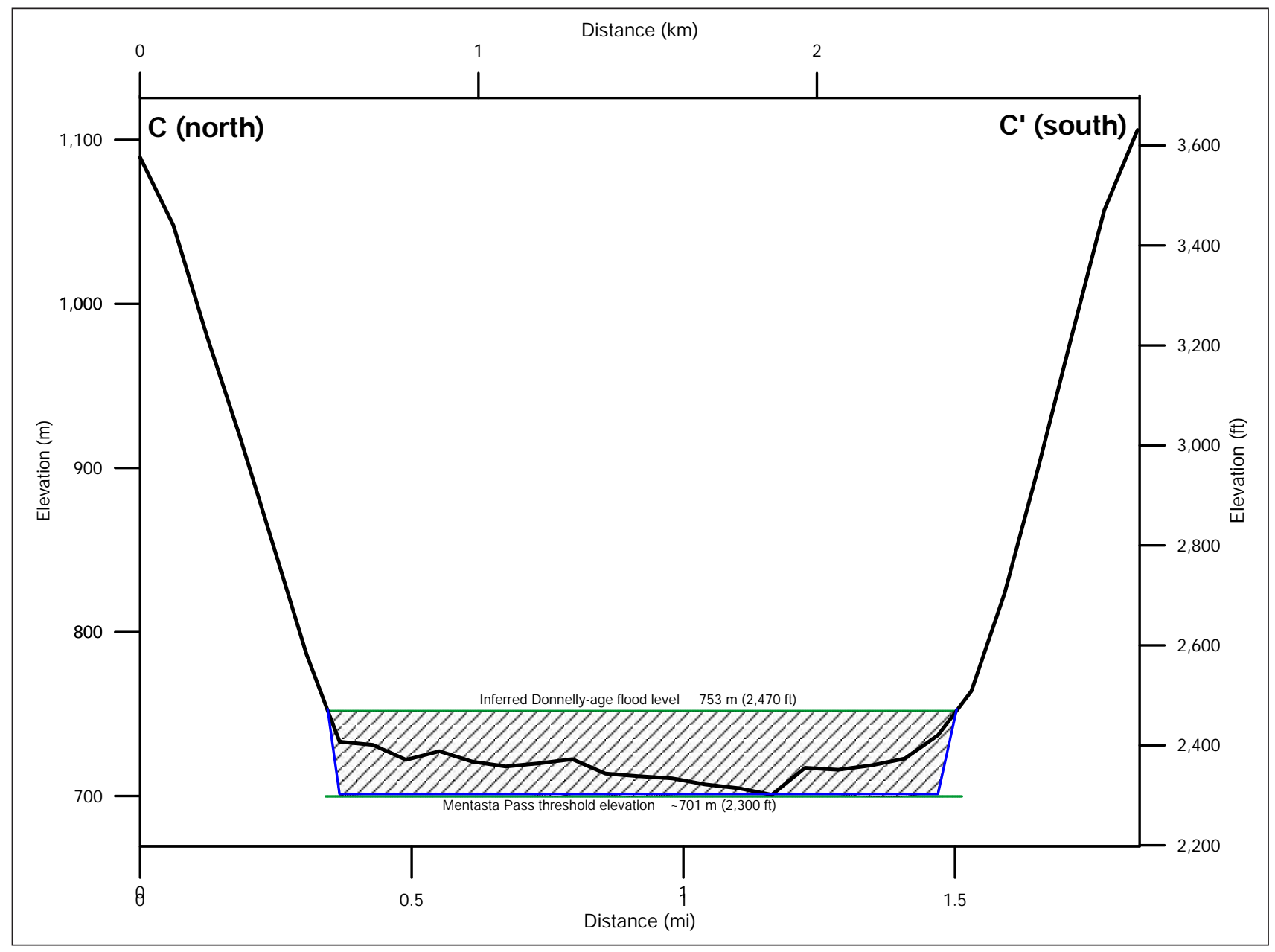

Figure 40. Bare-earth topographic profile C-C' from IFSAR-derived DEM across 1.8-km-wide Mentasta Pass, northwestern Nabesna D-5 Quadrangle, with superimposed flood cross section during largest Donnelly jökulhlaups. Location of profile C-C' shown in figure 35. Vertical exaggeration $~ 8.6$. Paleoflood flow parameters are provided in table 4. 
3. Calcareous valves of the small freshwater fingernail clam, Sphaerium (Sphaerium) nitidum Clessen, 1816 (Clarke, 1981), which were collected in a roadside exposure of well-bedded lacustrine sand that accumulated in a drained, dune-dammed lake along the Taylor Highway, dated $12,515 \pm 40$ RC yr B.P. $(14,750$ cal. yr B.P.) (WW 3861) (sheet 4, locality F-1; table 1, RC-10). This latest Donnelly age dates the impoundment of the former lake and represents a minimum age for the accumulation of the dune field. In the northwestern corner of the Tetlin
Junction dune field near the floodplain of the Tanana River, charcoal from eolian sand beneath retransported dune sand dates $8,100 \pm 40 \mathrm{RC}$ yr B.P. $(9,020 \mathrm{cal}$. yr B.P.) (Beta 252314) (sheet 4; table 1, RC-11), indicating at least one interval when the dune field was locally reactivated during Holocene time (Reger and others, 2011). A minimum age for the loess capping the eolian sand is established by the widespread presence of the White River Ash just beneath the vegetation mat in the Tetlin Junction dune field (see following discussion). Periodic extensive

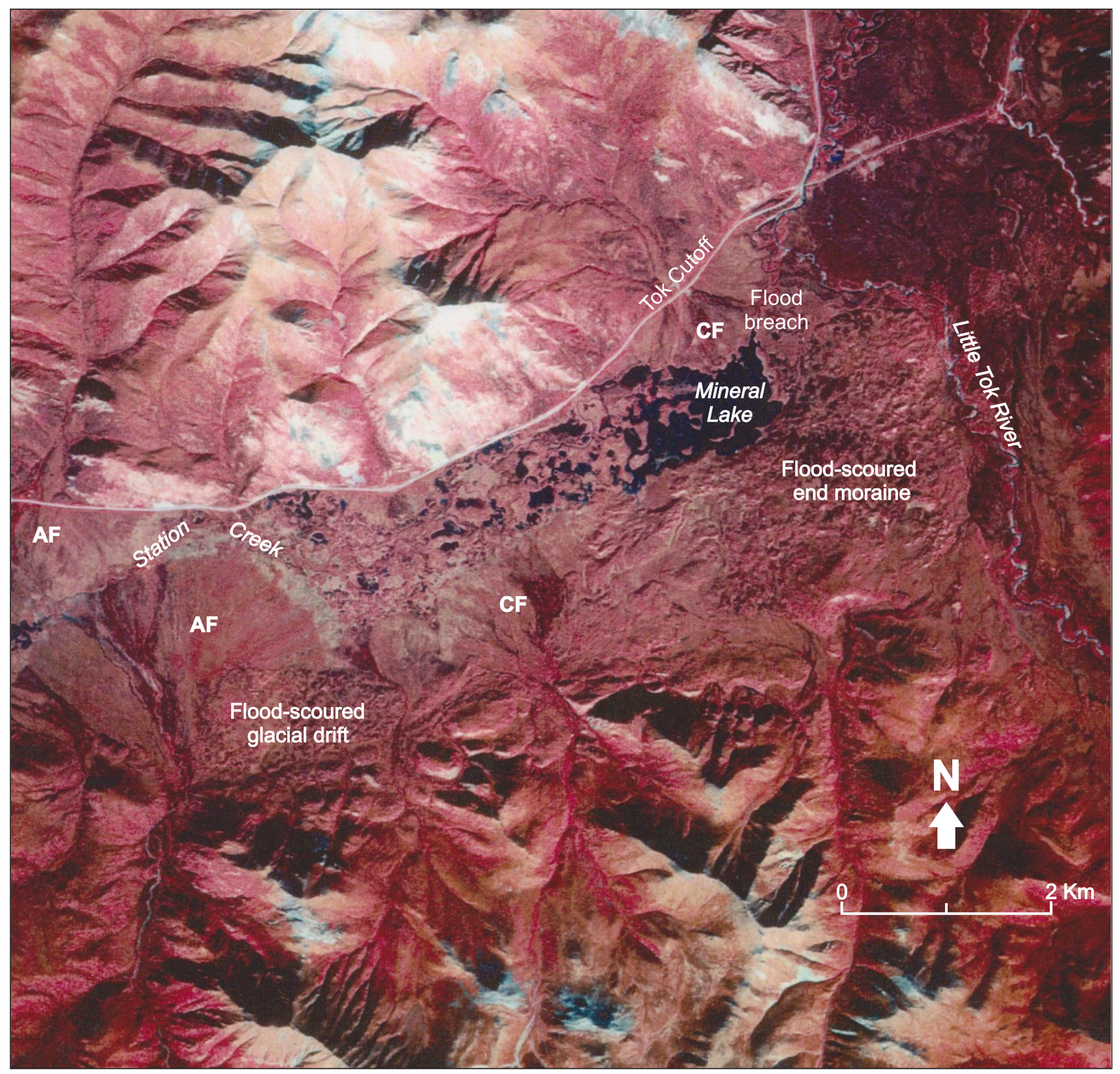

Figure 41. Vertical false-color infrared aerial photograph showing flood-modified Mineral Lake end moraine and associated landforms, northwestern Nabesna D-5 Quadrangle (Alaska High Altitude Photograph ALK 60 CIR 3928, taken August 1981). Symbols: AF = postflood tributary alluvial fan, $C F=$ postflood tributary colluvial-alluvial fan. 


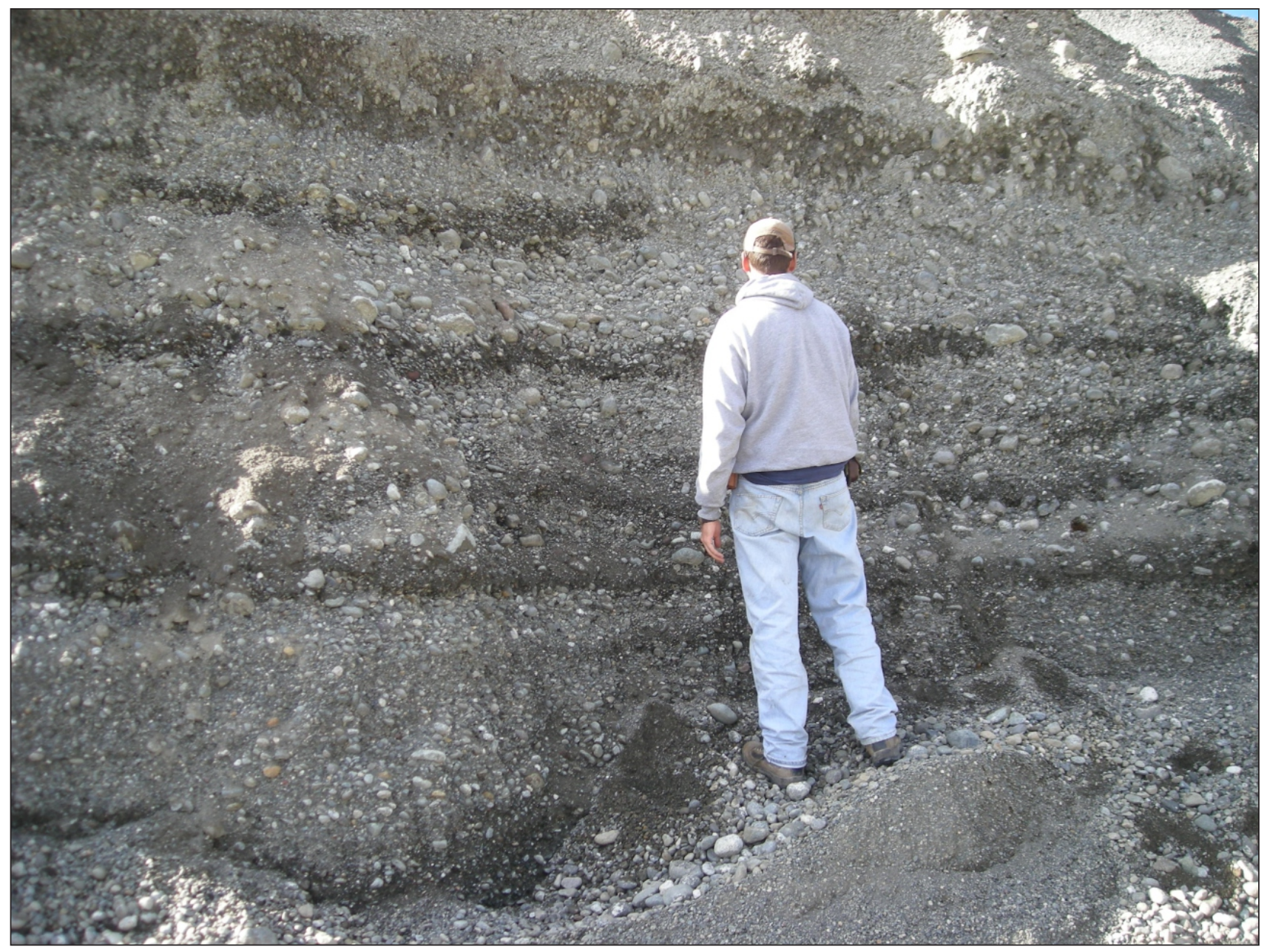

Figure 42. Gravel-pit exposure of crudely bedded jökulhlaup gravels in Little Tok River valley, southwestern Tanacross A-5 Quadrangle. Photograph taken 8/5/2008.

wildfires continue to disrupt the vegetation cover in the dune field, allowing local deflation and displacement of the near-surface sands (fig. 6).

Deposition of eolian sand was widespread from the Tetlin Junction dune field southeastward through the Alaska Highway corridor, where gray eolian sand beneath the thin loess cover discontinuously blankets and laps against bedrock ridges and hills of the southern YukonTanana Upland (Reger and others, 2012a) (fig. 45). These deposits form a discontinuous belt of vegetated, stabilized dunes up to $-20 \mathrm{~m}$ high along the Alaska Highway. Orientations of longitudinal dunes and associated hairpin dunes demonstrate that the floodplains of both the Tanana and Nabesna rivers were sources of abundant sand entrained by winds consistently blowing parallel to the corridor axis from the northwest (Reger and others, 2012a).

Late Donnelly and Holocene radiocarbon ages associated with northwest-trending dunes in the Riverside
Bluff exposure near the mouth of Bitters Creek $-22 \mathrm{~km}$ northwest of Northway Junction provide limits for local eolian sand deposition (Reger and others, 2012a, figs. 4 and 5) (sheet 5). Fernald (1965) dated woody peat beneath the base of the thick section of horizontal to gently dipping sand beds at $>42,000 \mathrm{RC}$ yr B.P. $(>45,350 \mathrm{cal}$. yr B.P.) (W 976) (table 1, RC-12). Horizontally laminated sand and silt near the middle of the Riverside Bluff section date $25,800 \pm 800 \mathrm{RC}$ yr B.P. $(29,770 \mathrm{cal}$. yr B.P.) (W 1174) (table 1, RC-13). A date of 6,200 $\pm 300 \mathrm{RC}$ yr B.P. (7,010 cal. yr B.P.) (W 1167) (table 1, RC-14) for black peat $\sim 1 \mathrm{~m}$ above the sand section is a minimum age for eolian deposition at the site (Reger and others, 2012a, fig. 4). In a section measured at the southeastern end of Riverside Bluff, a close maximum-limiting age for the beginning of local dune formation is indicated by a date of $12,230 \pm 120 \mathrm{RC}$ yr B.P. $(14,250$ cal. yr B.P. $)$ (USGS 1037) (table 1, RC-15) for cross-bedded sands. Near-horizontal laminated sand and silt beds near the 


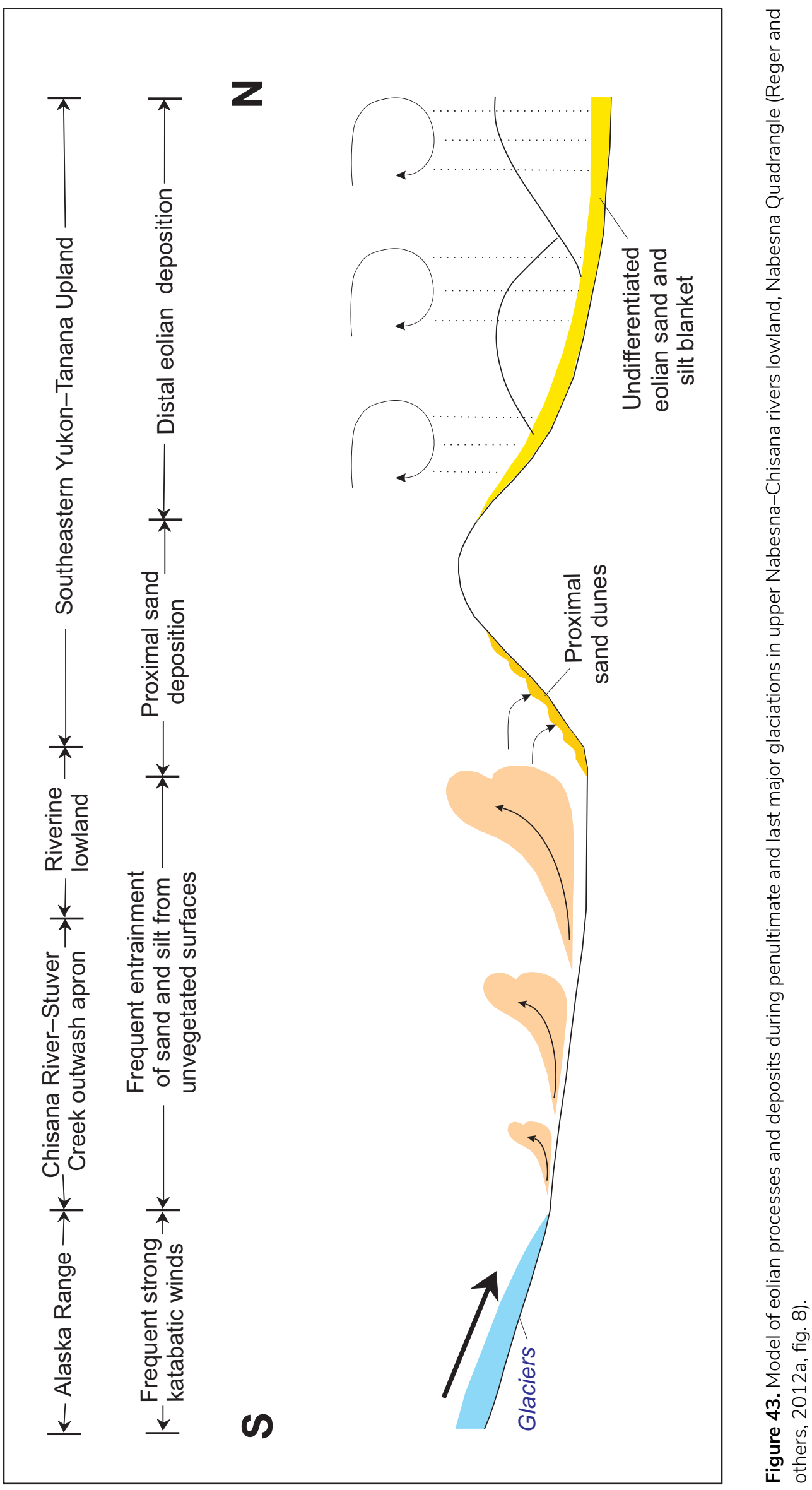




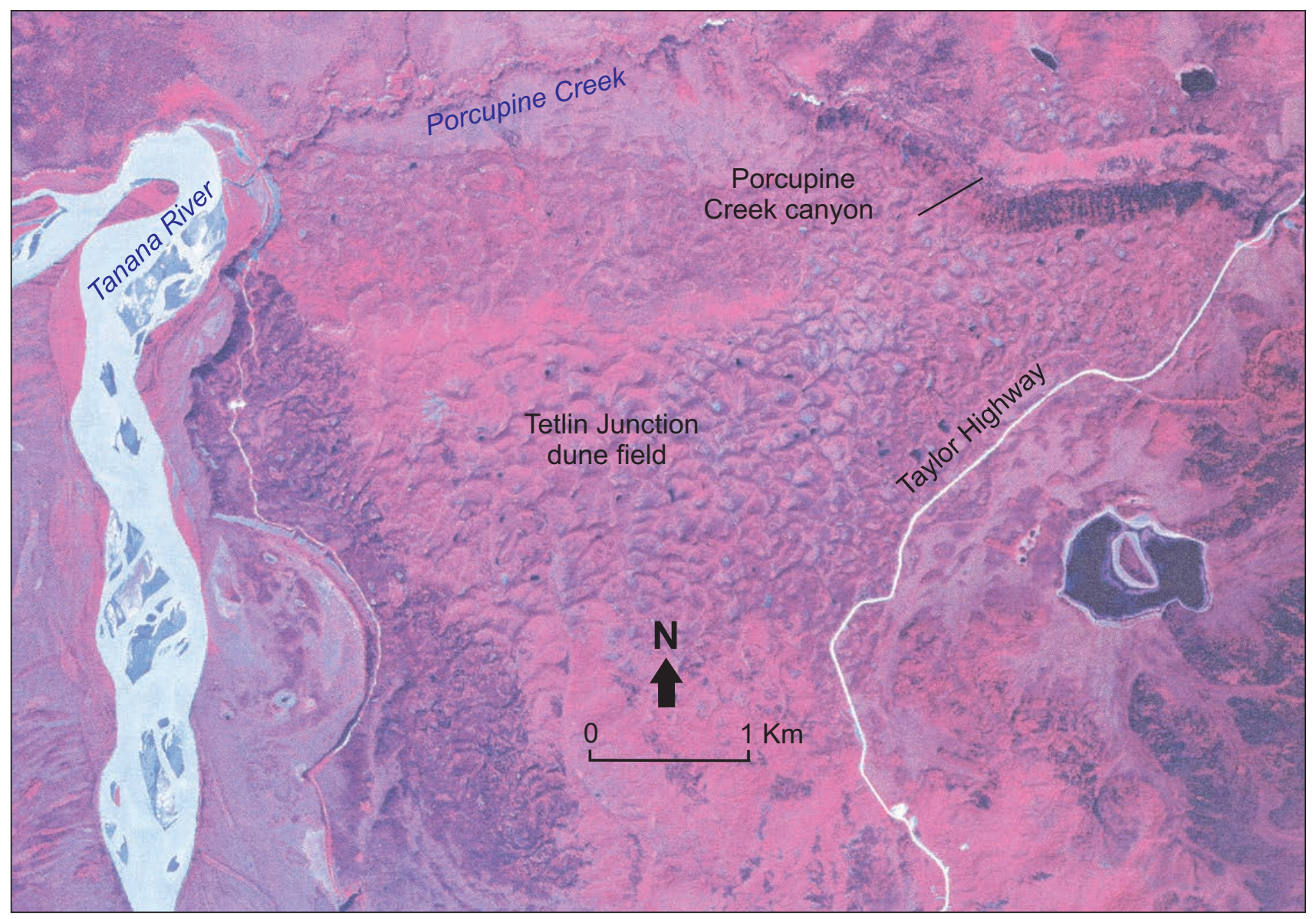

Figure 44. Vertical false-color infrared aerial photograph of Tetlin Junction dune field, east-central Tanacross B-4 Quadrangle (Alaska High Altitude Photograph ALK 60 CIR 262, taken July 1978).

middle of the sand-dune section date $11,880 \pm 180 \mathrm{RC}$ yr B.P. (13,740 cal. yr B.P.) (I 11,704) (table 1, RC 16) and were interpreted to be alluvium by Fernald (1965) and pond sediments by Carter and Galloway (1984). However, they could be eolian sand sheets deposited during the MIS 2 glaciation in conditions of seasonally frozen sand sources that were cemented by pore ice, sparse vegetation, high water tables, and seasonal snow cover (Lea, 1990; Lea and Waythomas, 1990). Cross-bedded sands above the horizontal sand section probably represent late Donnelly and Holocene reworking of the MIS 2 sand sheets to form the surface dunes at the site.

Moderately indurated Bt horizons in soil profiles on steep, permafrost-free, south-facing slopes indicate that some of the eolian sand could date back to the penultimate glaciation (fig. 46).

We suggest that north-blowing katabatic winds entrained sand and silt from the periodically replenished surface of the outwash complex in the Chisana River-Stuver
Creek drainages and from the adjacent riverine lowlands, and deposited an immense volume of sand against bedrock hills and in lowlands of the nearby southeastern Yukon-Tanana Upland. The orientations of transverse dunes in the Gardiner Creek dune field are evidence that summer winds blowing from the northwest and southwest subsequently reworked the abundant eolian sand to form parabolic dunes that are now vegetated and stabilized (fig. 47). Tributaries of Gardiner Creek and other local drainages appear to be clogged by dune sand, lowland loess, and retransported eolian sediments, forming dune-dammed ponds and lakes, and numerous small thaw lakes are present in ice-rich silts (Reger and others, 2012a) (sheet 6).

Excavations in frozen sand dunes typically encountered fine to medium sand with up to a trace (4-12 percent) of silt beneath 15 to $30 \mathrm{~cm}$ of loess. Depths to permafrost ranged from 45 to $68 \mathrm{~cm}$, and little visible ice was observed. Analyses of gravimetric soil moisture ${ }^{14}$ indicate that soil moisture in frozen eolian sand ranges from 17 to 45 percent (table 5). Thawing samples were thixotropic.

\footnotetext{
${ }^{14}$ Percent gravimetric soil moisture $=[$ wet or frozen soil weight - dry soil weight $/$ dry weight $] \times 100$.
} 


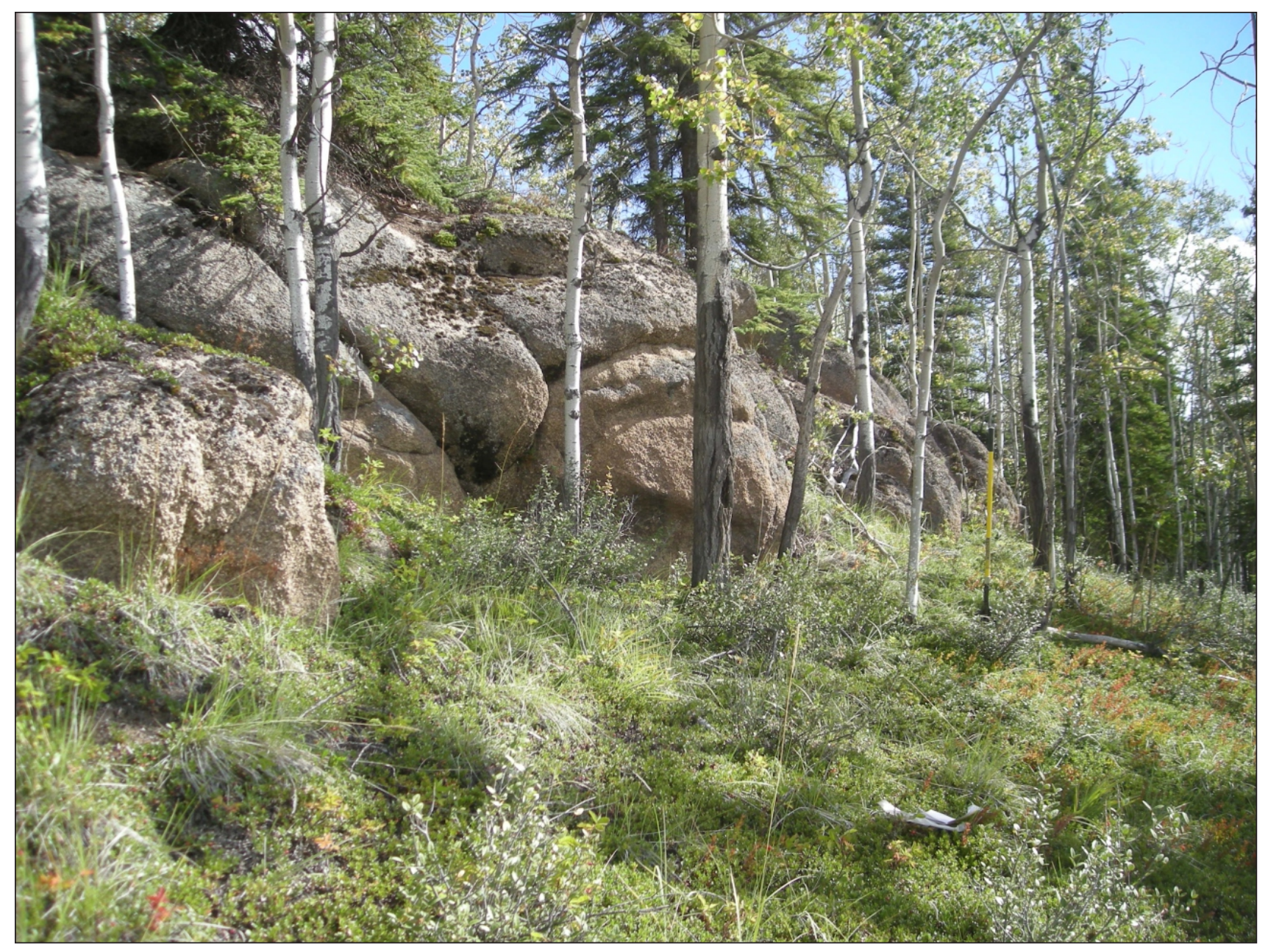

Figure 45. Rounded, weathered granitic tor standing above eolian sand blanket in Material Site 62-1-019-5 north of AMP 1280.4, northeastern Tanacross A-3 Quadrangle (Reger and others, 2012a, fig. 6A). Relief of aplite dikes and mafic inclusions is up to $10 \mathrm{~cm}$. Scattered black spruce and quaking aspen trees and kinnikinnik-grass mat indicate this south-facing slope is xeric. Vertical yellow shovel handle in lower right quadrant is $1 \mathrm{~m}$ long. Photograph taken 8/11/2008.

Typical vegetation on stabilized dunes with good nearsurface drainage is mixed robust black spruce, paper birch, and balsam poplar trees with scattered willow shrubs and moss mats up to $15 \mathrm{~cm}$ thick (Reger and others, 2012a) (fig. 48). Quaking aspen trees grow on well-drained, southfacing slopes free of permafrost. In this setting, soil profiles are as deep as $60 \mathrm{~cm}$. In moist interdune areas, where nearsurface drainage is impeded by shallow permafrost, the dominant vegetation is scattered to dense stands of stunted black spruce trees and willow shrubs with moss mats 23 to $28 \mathrm{~cm}$ thick. Sedge tussocks, up to $-30 \mathrm{~cm}$ high with standing water between them, typically grow in wetter sites.

\section{Eolian and retransported silt, including tephras}

Bedrock hills and ridges in the southern YukonTanana Upland are covered by loess that caps the eolian sand blanket. Loess covers range in thickness from -10 to $25 \mathrm{~cm}$, with a measured maximum of $-97 \mathrm{~cm}$ in the corridor. In samples of frozen inorganic silt (loess) recovered from two test pits, gravimetric soil moisture was 21 to 39 percent (table 5), and depths to permafrost ranged from 25 to $55 \mathrm{~cm}$. Although no visible ice was observed in frozen loess, thawing loess is thixotropic. In frozen organic loess and retransported organic silt, depths to permafrost range from 34 to $60 \mathrm{~cm}$. Analyses of four gravimetric soil moisture samples indicate that 33 to 345 percent soil moisture is present in frozen lowland and reworked loess (table 5). Ground ice was not visible in most reworked silt samples, but scattered clear crystals $\leq 3 \mathrm{~mm}$ across were visible in the sample with the highest soil moisture. These retransported sediments are typically thixotropic when thawing.

A prominent late Holocene tephra, the White River Ash (WRA), is distributed in northern (WRAn) and 
Figure 46. Profile (SP-14) showing soil layers formed by weathering in eolian section exposed in Material Site 621-020-5 on ridge crest north of AMP 1276.0, northeastern Tanacross A-3 Quadrangle (Reger and others, 2012a, fig. 7) (sheet 5). Photograph taken 8/11/2008.

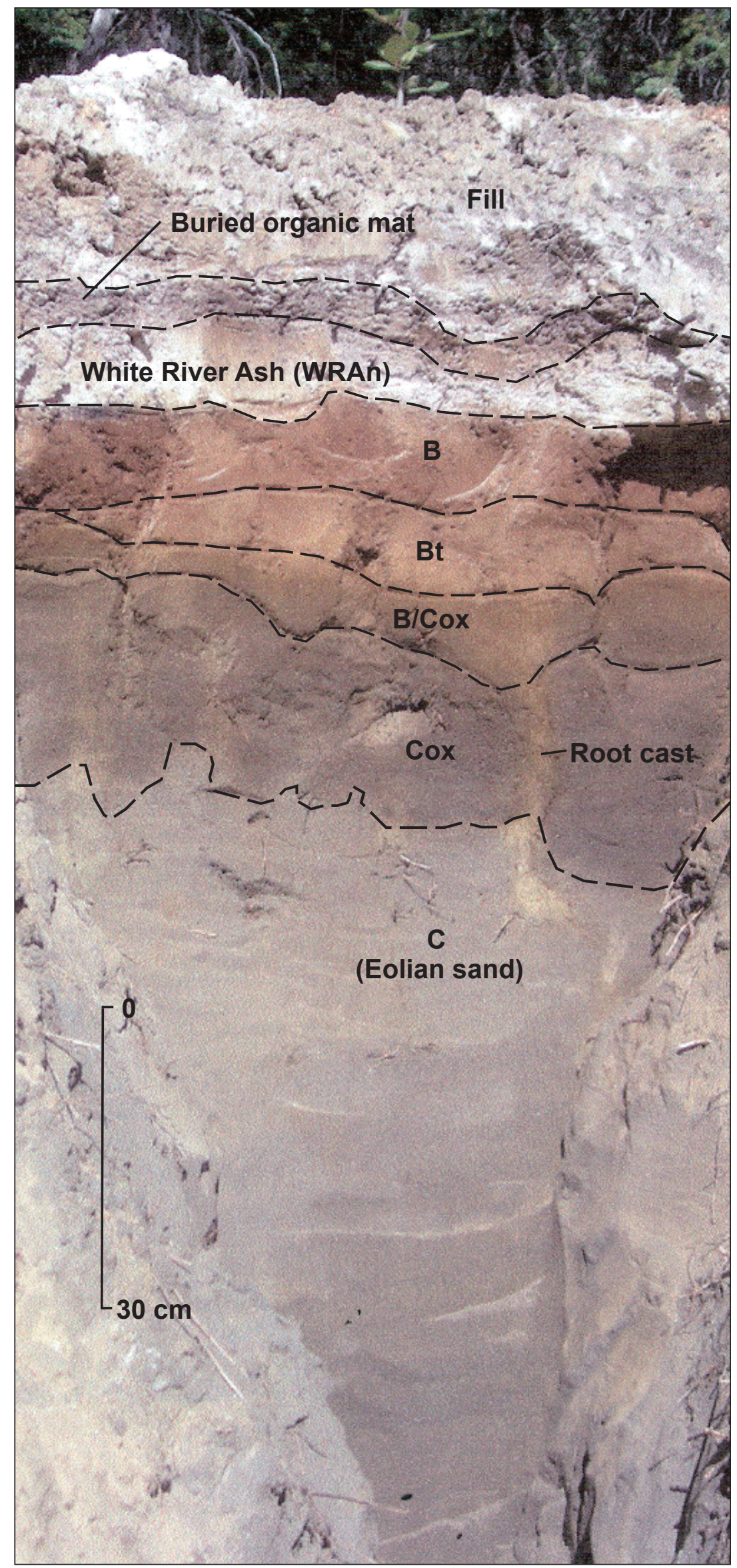


Table 5. Gravimetric soil moisture in frozen samples of eolian sand, loess, and retransported silt and sand in the Alaska Highway corridor, Tanacross and Nabesna quadrangles (Reger and others, 2012b, table 1).

\begin{tabular}{|c|l|c|c|}
\hline \multirow{2}{*}{$\begin{array}{c}\text { Sample } \\
\text { number }\end{array}$} & \multicolumn{1}{|c|}{ Composition } & \multicolumn{2}{|c|}{$\begin{array}{c}\text { Moisture content } \\
\text { (percent dry weight) }\end{array}$} \\
\cline { 3 - 4 } & & Lowland and \\
E-1a & $\begin{array}{l}\text { Frozen eolian sand; well bonded, no visible ice } \\
\text { Unfrozen, wet, silty, retransported loess; thixotropic }\end{array}$ & 21 \\
\hline M-1b & 45 & 345 \\
\hline M-2 & $\begin{array}{l}\text { Frozen, well-bonded, black, peaty and woody retransported organic } \\
\text { silt; scattered clear ice crystals } \leq 3 \text { mm across }\end{array}$ & - & 39 \\
\hline M-3 & Frozen, well-bonded, loess; no visible ice; thixotropic when thawed \\
\hline M-4 & $\begin{array}{l}\text { Frozen, well-bonded, fine to medium eolian sand with trace silt; } \\
\text { thixotropic when thawed }\end{array}$ & - & - \\
\hline M-5 & Frozen, well-bonded, fine to medium eolian sand; no visible ice & 19 & - \\
\hline M-6 & $\begin{array}{l}\text { Frozen, moderately bonded, medium eolian sand with trace silt; no } \\
\text { visible ice }\end{array}$ & 19 & - \\
\hline M-7 & Frozen, well-bonded, retransported organic silt; no visible ice & - & 76 \\
\hline M-8 & $\begin{array}{l}\text { Frozen, moderately bonded, clean, fine to medium eolian sand; no } \\
\text { visible ice }\end{array}$ & 17 & - \\
\hline M-9 & $\begin{array}{l}\text { Frozen, well-bonded, medium eolian sand; no visible ice; thixotropic } \\
\text { when thawed }\end{array}$ & 25 & - \\
\hline M-10 & $\begin{array}{l}\text { Frozen, well-bonded, retransported organic fine sand with some silt; } \\
\text { no visible ice }\end{array}$ & - & 60 \\
\hline M-11 & Frozen, well-bonded, retransported silt; no visible ice & - & 33 \\
\hline
\end{tabular}

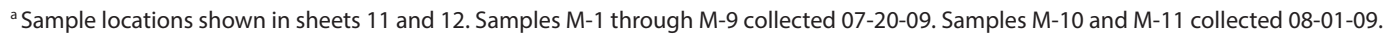

eastern (WRAe) lobes in east-central Alaska (Richter and others, 1995; Robinson, 2001; Lerbekmo, 2008) (table 6). WRAn crops out in thicknesses of 10 to $15 \mathrm{~cm}$ just beneath the surface organic mat in cuts along the Alaska Highway from Tetlin Junction to the Canada border. Radicoarbon dating indicates that WRAn was ejected 1,605-1,805 cal. yr B.P. from a vent near the summit of glacier-covered Mount Churchill in the western St. Elias Mountains (Davies and others, 2016). Clague and others (1995) dated the outer growth rings of four standing trees entombed in WRAe, and obtained a weighted mean age of 1,147 cal. yr B.P. for the eruption that killed them. Later radiocarbon dating indicates that the eastern lobe was deposited 1,095-1,170 cal. yr B.P. (table 6). Accumulating evidence indicates that Mount Churchill has an active Holocene eruptive history.

Schaefer (2002) investigated a 10-m-thick eolian section near AMP 1284.0 in the Tanacross A-3 Quadrangle (fig. 49) and identified several Quaternary tephras, including the White River Ash and the Old Crow, Sheep Creek, and Tetlin tephras (fig. 50). The Tetlin tephra was first recognized in this section. Shaefer's geochemical and ${ }^{40} \mathrm{Ar} /{ }^{39} \mathrm{Ar}$ analyses indicate that the Tetlin tephra was erupted from
Mount Drum 627,000 \pm 47,700 yr ago. Thus, these tephras in the upper Tanana River valley demonstrate periodic explosive activity by volcanoes in the Wrangell and St. Elias mountains during the late Quaternary.

Deposits of retransported loess and sand range from massive to thinly bedded, have generally planar bedding, and are organic rich. Because of their fetid odor produced by decaying organic matter, these deposits were called "muck" by early miners (Tuck, 1940). Where fine-grained upland sediments were available for entrainment by flowing water, silt- and sand-charged hyperconcentrated flows retransported them to lower slopes and valley floors, burying surface organic materials, including plants, bones, and carcasses (Guthrie, 1990; Reger and others, 2012a, p. 15). Local tilting, faulting, and overturning of bedding in retransported silt and sand are generally associated with displacements related to the thawing of ground-ice masses (Péwé and others, 1997, 2009; Muhs and others, 2001).

Near AMP 1276.0 in the south-central Tanacross A-2 Quadrangle (Reger and others, 2012a, sheet 1, locality F-1), a single, small astragalus bone from the 
Table 6. Summary of distal rhyolitic tephras in and near the Alaska Highway corridor.

\begin{tabular}{|l|l|l|l|l|}
\hline \multicolumn{1}{|c|}{ Tephra } & \multicolumn{1}{|c|}{ Source } & \multicolumn{1}{c|}{$\begin{array}{c}\text { Age } \\
\text { cal yr B.P. }\end{array}$} & \multicolumn{1}{c|}{$\begin{array}{c}\text { Dating } \\
\text { technique }\end{array}$} & \multicolumn{1}{c|}{ Reference } \\
\hline $\begin{array}{l}\text { White River Ash, } \\
\text { northern lobe (WRAn) }\end{array}$ & Mt. Churchill & $1,605-1,805$ & Radiocarbon & Davies and others (2016) \\
\hline $\begin{array}{l}\text { White River Ash, } \\
\text { eastern lobe (WRAe) }\end{array}$ & Mt. Churchill & $1,095-1,170$ & Radiocarbon & Davies and others (2016) \\
\hline Unit G of Hayes tephra F & Hayes Volcano & $3,910-4,205$ & Radiocarbon & Davies and others (2016) \\
\hline Dawson & $\begin{array}{l}\text { Emmons Lake } \\
\text { volcanic center }\end{array}$ & $\sim 27,000-30,500 \pm 8,400$ & Ar ${ }^{39 /} \mathrm{Ar}^{40}$ & $\begin{array}{l}\text { Davies and others (2016) } \\
\text { Burgess and others (2019) }\end{array}$ \\
\hline $\begin{array}{l}\text { Sheep Creek (SCt) } \\
\text { SCt-CC, C, K, and A } \\
\text { SCt-F }\end{array}$ & $\begin{array}{l}\text { Wrangell volcanic } \\
\text { field }\end{array}$ & $\begin{array}{l}\sim 80,000 \\
190,000 \pm 20,000\end{array}$ & $\begin{array}{l}\text { Glass FT } \\
\text { Loess TL }{ }^{a}\end{array}$ & $\begin{array}{l}\text { Westgate and others (2008) } \\
\text { Berger (2003) }\end{array}$ \\
\hline Old Crow & $\begin{array}{l}\text { Emmons Lake } \\
\text { volcanic center }\end{array}$ & $\begin{array}{l}124,000 \pm 10,000 \\
202,900 \pm 9,500\end{array}$ & $\begin{array}{l}\text { Glass FT } \\
\text { Zircon U/Pb }\end{array}$ & $\begin{array}{l}\text { Preece and others (2011) } \\
\text { Burgess and others (2019) }\end{array}$ \\
\hline Tetlin & Mt. Drum & $627,500 \pm 47,700$ & Ar ${ }^{39 /} \mathrm{Ar}^{40}$ & Schaefer (2002) \\
\hline
\end{tabular}

${ }^{\mathrm{a}}$ Fission track.

${ }^{\mathrm{b}}$ Thermoluminescence.

left rear foot of a prehistoric horse ${ }^{15}$ was discovered in a thawed 4-yr-old highway cut through formerly frozen, dark brown (10YR3/3), retransported organic silt with a trace of very fine sand (sheet 5, locality F-2). The Equus ankle bone was subsequently dated at 40,590 $\pm 600 \mathrm{RC}$ yr B.P. (44,410 cal. yr B.P.) (Beta-252319) (table 1, RC 17), demonstrating that this prehistoric horse, one of the important elements of a diverse, steppe-adapted Pleistocene megafauna in eastern Beringia (Guthrie, 1968, 1982, 1990; Clague and others, 2004; Harington, 2011; Mann and others, 2013), lived during the MIS 3 interstade ${ }^{16}$, and establishing a maximum time limit for deposition of the enclosing reworked loess. No other bones were recovered at the fossil site, despite careful examination of the roadcut faces. The bleached nature of the bone indicates that, after the horse died, the body was probably scavenged and its bones scattered. The remains were exposed to surface weathering conditions long enough that surviving bones became bleached before they were transported downslope and buried. However, weathering of the fossil bone apparently did not totally destroy the collagen, an adequate amount of which remained to provide a reliable AMS radiocarbon age. Lack of bone staining demonstrates that the enclosing silt was frozen soon after burial of the bone and remained frozen until 2004, when the roadcut was excavated and the retransported loess started thawing.

\section{PERIGLACIAL FEATURES ASSOCIATED WITH BEDROCK}

Deposits and features resulting from the freezing and thawing of bedrock, the formation and decay of bedrock permafrost, and the downslope, gravity-driven displacement of the products of bedrock weathering form colluvial aprons and blankets beneath eolian sediments in the southern Yukon-Tanana Upland. Inactive features generally developed under former, more rigorous periglacial conditions than exist in the area today (Péwé, 1975a, b).

\section{Colluvium}

Crudely bedded to massive lenses, layers, and wedges of angular fragments derived from frost-rived, weathered local bedrock are overlain by eolian deposits along the Alaska Highway southeast of the Tok River bridge. They are termed the Tanana Formation elsewhere in central Alaska, and carry gold particles from upslope gold-bearing lodes and residual deposits downslope to locally auriferous fluvial gravels in valley bottoms in the Interior (Péwé, 1975a, b). In the study area, overlying eolian deposits mask near-surface slope colluvium so it is not widely distributed on accompanying map sheets. The coarse colluvial diamictons on steep slopes in the southeastern Alaska Highway corridor at least locally underlie, and are therefore older than, the Tetlin tephra, dated $627 \pm 47.7 \mathrm{ka}$

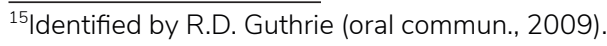

${ }^{16}$ According to Anderson and Lozhkin (2001), the stage 3 interstade occurred between 25-30 and 43 RC ka in interior Alaska. Clague and others (2004) date this nonglacial interval between 25 and 60 RC ka.
} 
by Schaefer (2002), although they could be much younger elsewhere in the corridor, particularly on upper slopes in the southeastern Yukon-Tanana Upland.

Between Scotty Creek and Mirror Creek in the southeastern corner of the corridor, a mantle of undifferentiated, frost-rived colluvium forms blankets and aprons on lower slopes of hills and ridges of schist bedrock (Richter, 1976). Slope diamictons have a silty sand matrix, likely because of an influx of eolian sediments. Surface loess is thin in this segment. Clasts are composed of angular fragments of the local bedrock. Reworking of these deposits by debris flows left tongues and fans of relatively coarse, mixed colluvium-alluvium in valley bottoms and on proximal fan surfaces in valleys (Reger and others, 2012a) (sheets 5 and 6). Fine-grained components of slope colluvium and retransported eolian sediments were washed into

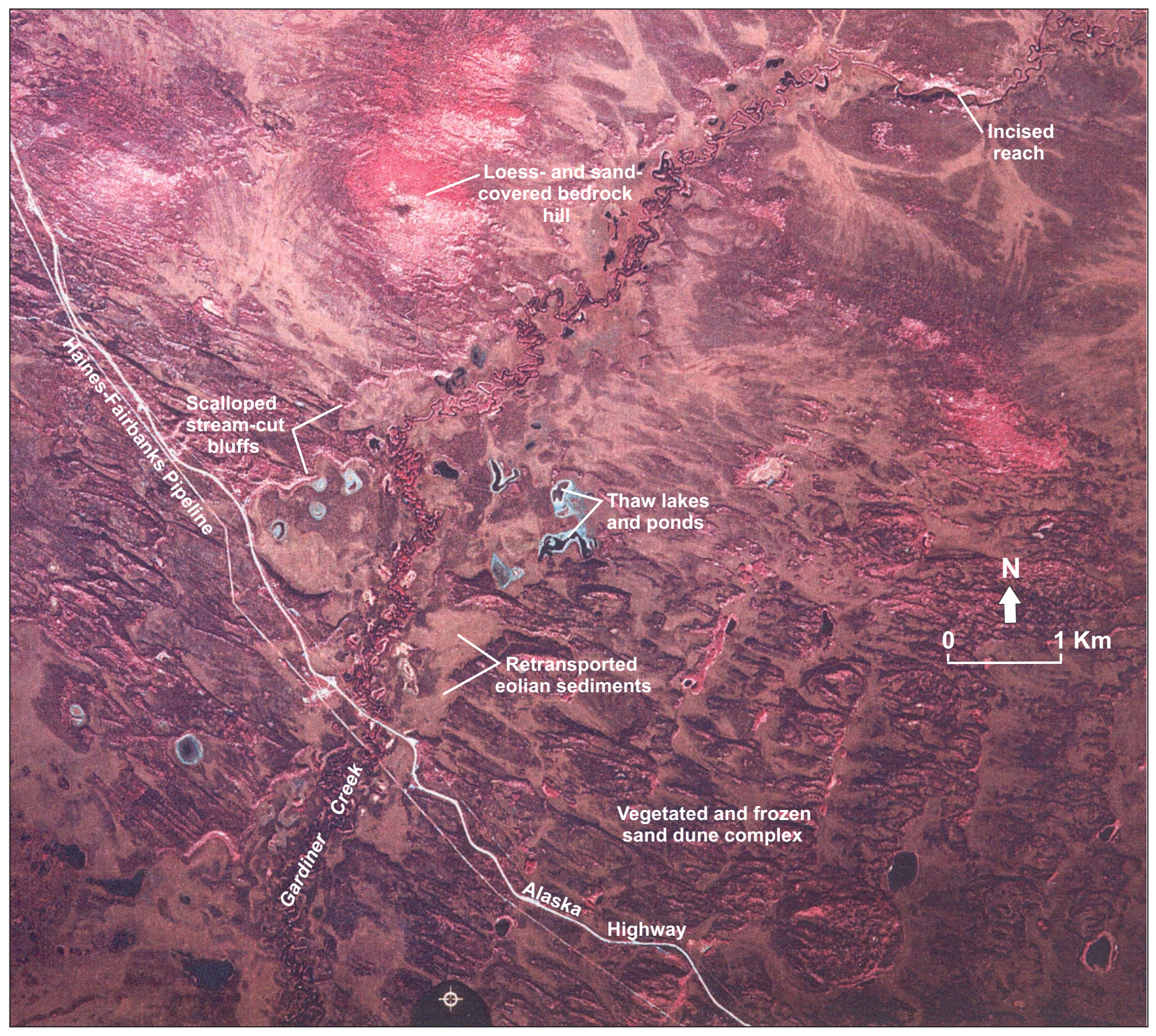

Figure 47. Vertical false-color infrared aerial photograph showing stabilized, frozen sand dunes and retransported eolian sediments in Gardiner Creek lowland, west-central Nabesna D-1 Quadrangle (Alaska High Altitude Photograph ALK 60 CIR 3944 , taken August 1981) (Reger and others, 2012a, fig. 8). Waves of parabolic transverse sand dunes, now vegetated by black spruce and broadleaf trees, were deposited by strong northwest and west winds blowing across sediment-rich floodplains in this section of the upper Tanana River valley. Thaw ponds and thaw lakes are evidence that eolian sediments are frozen and locally ice rich. Sedge wetlands on frozen, ice-rich, retransported eolian sediments demonstrate that subsurface drainage is generally impeded. Comparison of radii of scalloped bluffs and former stream channels along bases of stream-cut bluffs with radii of tortuously winding Gardiner Creek reveals that the modern stream is underfit for the valley it occupies. 


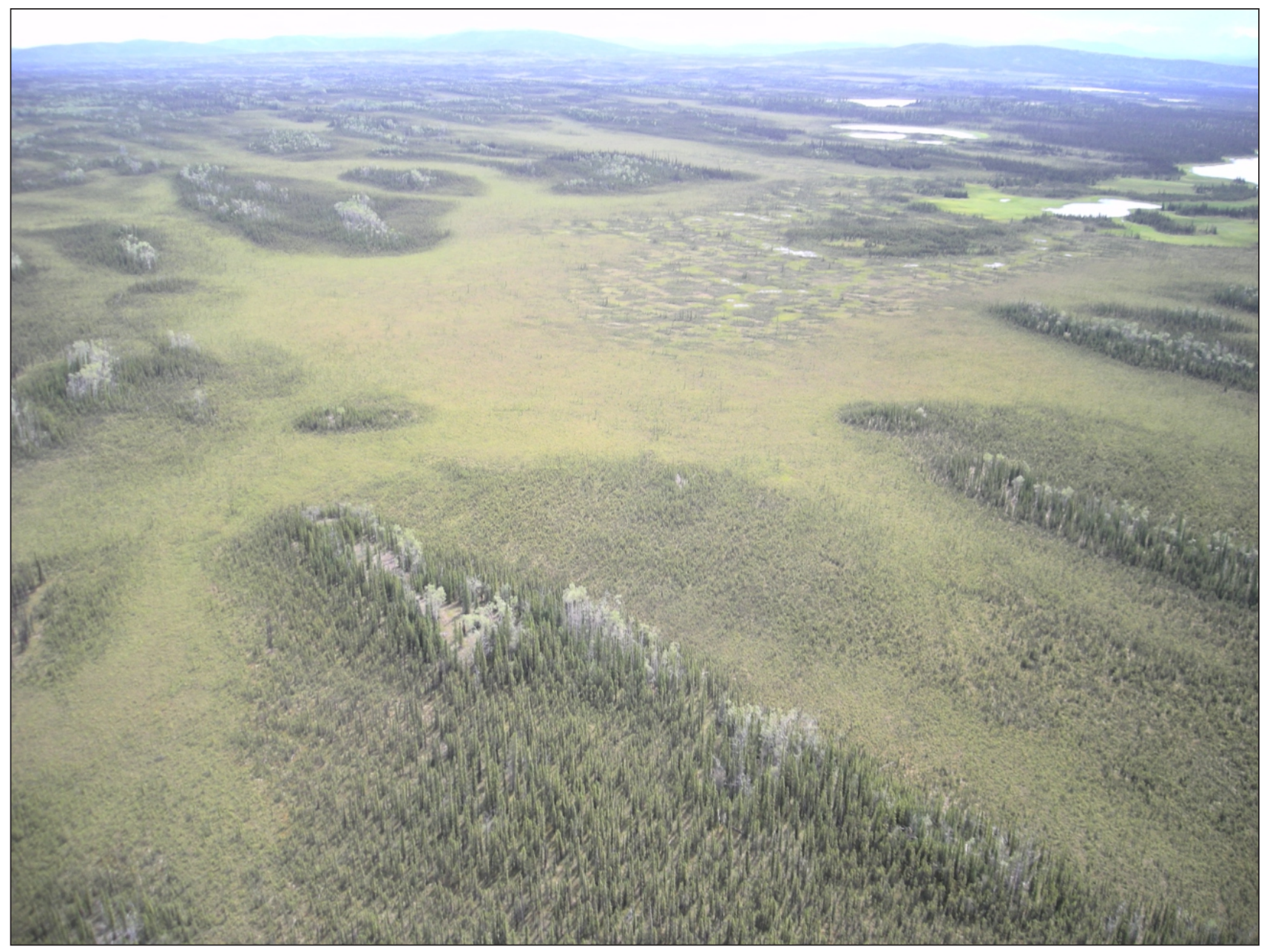

Figure 48. Aerial view southwestward of stabilized sand dunes in Gardiner Creek lowland, west-central Nabesna D-1 Quadrangle. Well-drained crests of sand dunes, where permafrost is $\geq 60 \mathrm{~cm}$ deep, support mixed forest of robust black spruce, balsam poplar, and paper birch trees with scattered willow shrubs. In moist interdune areas, dominant vegetation is scattered to dense, stunted black spruce trees and willow shrubs with moss ground cover. Photograph taken 7/23/2009.

distal valley bottoms, where they were likely mixed with lowland loess and frozen.

\section{Sand wedges}

Just east of AMP 1303.0, in a former roadcut of the Alaska Highway, later deeply buried beneath thick construction-waste fill (sheet 4, locality F), we found 13 sand wedges in groups or as single wedges in grussified granitic bedrock (Reger and Hubbard, 2010, sheet 4, locality A) (fig. 51). Fillings of some wedges included angular, pebble-sized fragments of weathered granitic rock that were distributed in clusters near the wedge axis or near the sidewalls, and several sand wedges exhibited silty sand-filled tension cracks up to $-5 \mathrm{~mm}$ wide in massive sand (fig. 52). The largest sand wedges measured $0.4 \mathrm{~m}$ wide and extended $-1.6 \mathrm{~m}$ into the weathered bedrock. The sand wedges occupy modified, near-orthogonal joints striking $108^{\circ}$ and $205^{\circ}$ azimuths. The sand fills in the wedges were continuous with the overlying retransported eolian sand with rock fragments. This section is overlain by a weathered loess of variable thickness that contains a prominent Cca horizon. Capping the section is $-1-m$-thick loess bearing a post-Donnelly weathering profile.

The presence of these sand wedges along altered bedrock joints and wedge compositions indicate that these features have a complex history. They clearly predate the loess that caps the former exposures, so they are probably pre-Donnelly in age. In spite of the proximity of the site to the Tanana River, there is no evidence for erosion of the wedges by meltwater runoff or outburst floods. Instead, wedge fillings of retransported eolian sand containing fragments of weathered rock are evidence that former ice wedges melted and the overlying sandy colluvium collapsed into the resulting cavities, similar to polygonal sand and 


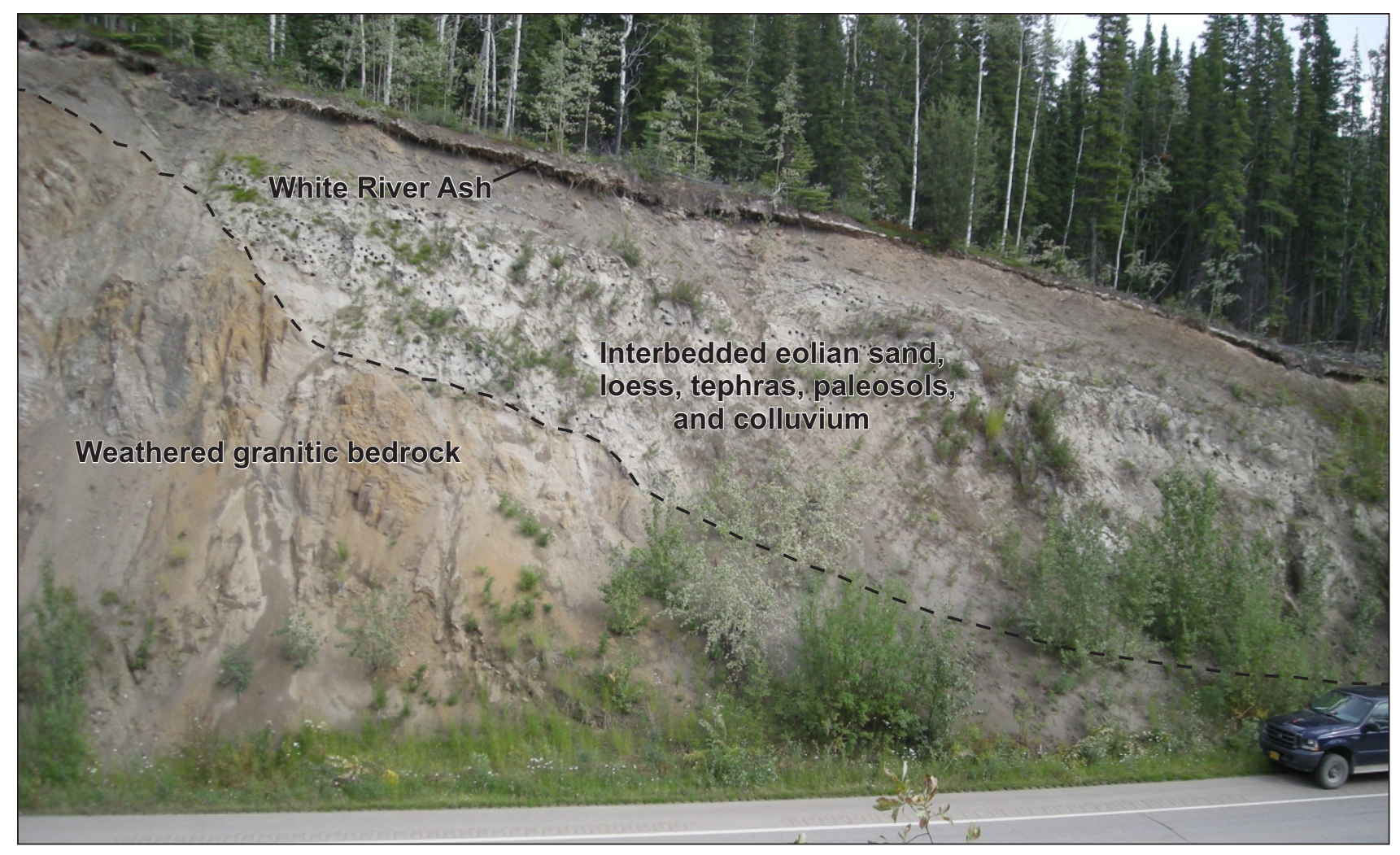

Figure 49. View north-northeastward of roadcut exposure of stratigraphic section 96TOK1 evaluated by Schaefer (2002) near AMP 1284.0, northeastern Tanacross A-3 Quadrangle (Reger and others, 2012a, fig. 13) (locality T-1 in sheet 5). Photograph taken 8/10/2008.

gravel wedges in proximal outwash of Donnelly age near Donnelly Dome south of Delta Junction (Péwé and others, 1969). Wedge fillings containing both sand mixed with angular grus fragments and thin tension cracks filled with silty sand in massive sand are evidence that some wedges were formerly composed of ice mixed with sand (fig. 52).

Primary sand wedges form in arid polar deserts of continuous permafrost, such as the dry valleys of Antarctica (Péwé, 1959) and in northern Alaska and arctic Canada (Murton and others, 2000). As a steppe flora apparently existed at this site during the last major glaciation (Young, 1982), we assume that a thin eolian-sand blanket accumulated and primary sand wedges formed in a sparsely vegetated steppe that was much colder than today. When local conditions were less arid but still very cold and windy, wedges of mixed ice and sand likely formed, and tundra vegetation was probably present (Black, 1976). Secondary sand wedges formed when local conditions changed, so that permafrost and ice wedges thawed and wedge-shaped fillings accumulated in the resulting cavities (French, 2007). Thawing of permafrost also could have been the result of climatic warming or in response to a wildfire that destroyed the local shrubland or wood- land vegetation (Chapin and others, 2006). Today, this upland site is generally unfrozen (Reger and Hubbard, 2010, sheet 2).

\section{MODERN GEOHAZARDS}

During our 2006-2012 reconnaissance field investigations in the Alaska Highway corridor, we identified several conditions and processes that could potentially affect future infrastructure development in and near the corridor, including seismic hazards, permafrost, slope instabilities, and flooding. Our evaluations are intended to provide general background information useful for planning more detailed, site-specific studies prior to future corridor developments.

\section{Seismic hazards Methods}

Initial surveys for active and potentially active faults in and near the Alaska Highway corridor involved the interpretation of stereoscopic aerial photography, remotely sensed imagery, digital elevation models, and topographic maps. We reviewed published and unpublished reports, many including geologic and geophysical maps, and 


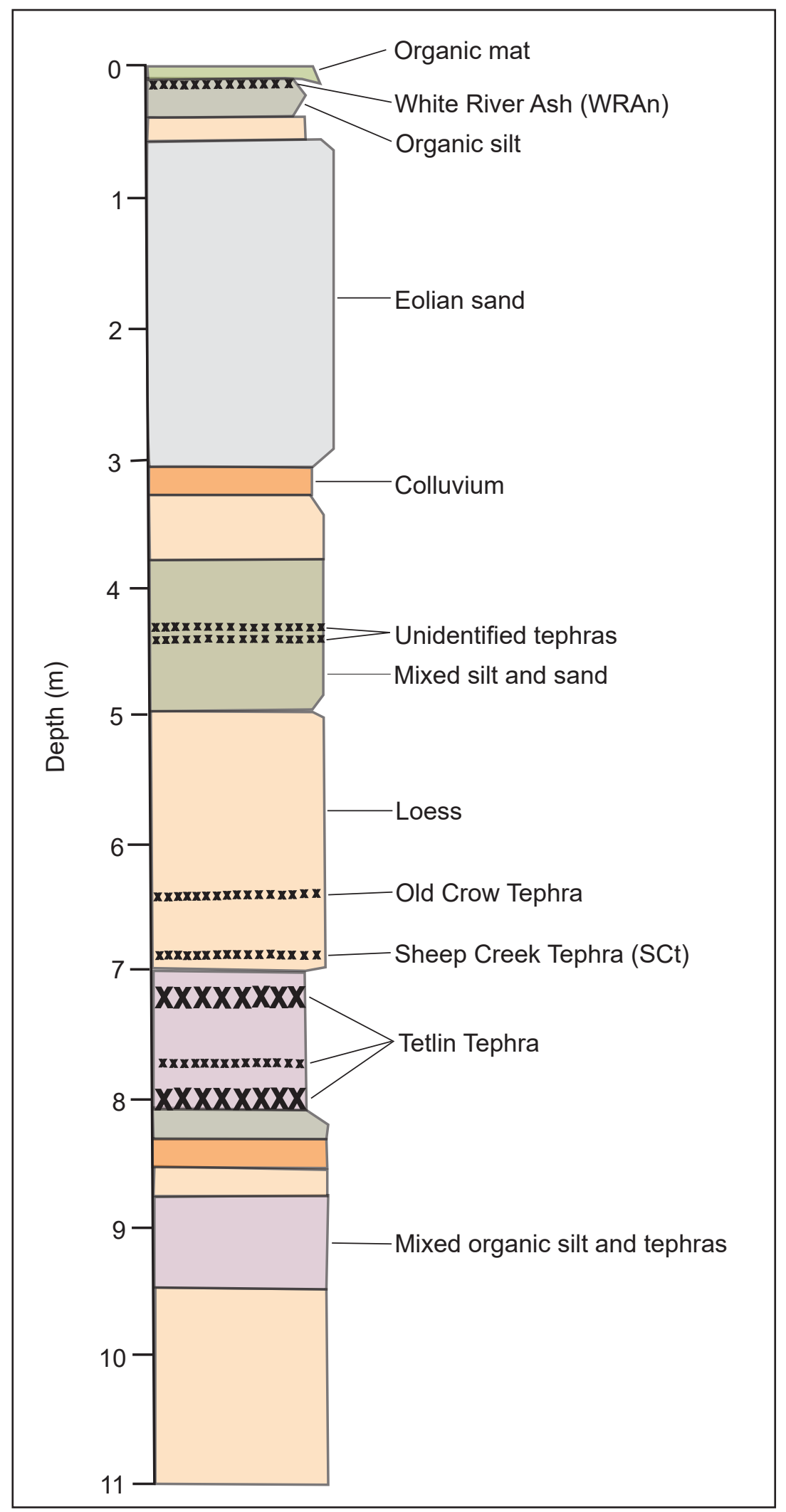

Figure 50. Generalized stratigraphic section 96TOK1 (after Schaefer, 2002, fig. 3). The Sheep Creek tephra (Sct) in this section has a 0.96 correlation coefficient with the mean SCt composition determined by Preece and others (2011) and SCt samples UT1052 and UT1051-P2 from the Ash Bend site, indicating that the F member of the Sheep Creek tephra is widespread in the Interior (Janet Schaefer, written commun., 2020). 
collated relevant information. We conducted initial aerial surveys in the field using fixed-wing aircraft and helicopters. Based on these studies and observations, we identified and selected several features for more detailed field investigations, including geologic mapping, scarp profiling, logging of stratigraphy in trenches across lineaments and fault scarps, and describing drill cores (Carver and others, 2008a, b, 2010; Koehler and Carver, 2012; Koehler and Woods, 2013). Detailed field descriptions of trench-wall exposures documented stratigraphic and structural relations, including the locations of fault planes, folds, and liquefaction features. We collected samples for granulometric analyses and radiocarbon dating, particularly in fault-displaced sections. We measured topographic profiles across lineaments and fault scarps using a hand level stabilized on an instrument rod of known height, read horizontal distances between survey stations through optical instruments from intercepts on a stadia surveying rod, and measured slope distances with a 50-m tape.

\section{Seismotectonic setting}

The regional tectonic framework of the eastern Alaska Range and the Alaska Highway corridor is controlled by the long, right-lateral, strike-slip Denali-Totschunda fault system, which trends along the axis of the Alaska Range and accommodates the westward translation of southcentral Alaska relative to the Interior (fig. 53). Crustal blocks move counterclockwise south of the Denali fault, developing compressive stresses in the Alaska Range north of the Denali fault (Freymueller and others, 2008). These compressive stresses have produced the $50-\mathrm{km}$-wide arcuate zone of north-vergent folding and thrust faulting, known as the Northern Foothills Fold and Thrust Belt (NFFTB) (Bemis and Wallace, 2007; Bemis and others, 2012). Folding and thrust faulting in this deformation zone have displaced Paleozoic rock units northward over late Neogene and Quaternary sediments in the Tanana River valley (Ridgway and others, 2002).

The major accomplishment of 2006-2012 DGGS paleoseismic reconnaissance investigations in the Alaska Highway corridor was demonstrating that the NFFTB extends eastward as far as the Tok River valley and defines the tectonically active northern margin of the eastern Alaska Range in the upper Tanana River valley (Carver and others, 2008a, b, 2010; Koehler and Carver, 2012; Koehler and Woods, 2013) (fig. 53). Prior investigations by Bemis and Wallace (2007) demonstrated that the NFFTB extends from the Toklat River in Denali National Park eastward to the Wood River south of Fairbanks. Simultaneous investigations recognized that the NFFTB extends eastward to the Donnelly Dome fault (Carver and others, 2006). These previous investigations were summarized in Bemis and others (2012), who used geomorphic expression, width of deformation, and orientations of fault strands to divide the NFFTB into four sections: the Kantishna Hills, western NFFTB, transition zone, and eastern NFFTB.

\section{Active faults}

Geomorphic and stratigraphic evidence collected during DGGS reconnaissance investigations permitted identification of active faults along which there were Holocene displacements in and near the Alaska Highway corridor. These faults have significant potential for generating future earthquakes. Surface evidence of active faulting includes offset, tilting, and folding of late Pleistocene landforms, and stratigraphic evidence involving offset and deformation of near-surface deposits and dating these events (Slemmons and Depolo, 1986; Bonilla and Lienkaemper, 1991). These active seismic structures have the potential to cause surface faulting hazards, including ground-surface displacements, in the corridor, and could produce widespread liquefaction and slope failures as a result of severe ground shaking.

In this report, we have incorporated terminology used in preliminary reports and line symbols on geologic maps prepared by our paleoseismologist colleagues, who identified two active segments of the Dot "T" Johnson fault, a major potential seismic source in the corridor. However, fault segments are typically identified by unique seismic histories (McCalpin, 1996), and the evidence compiled in this report is not sufficiently comprehensive to confidently evaluate the individual seismic structures for earthquake magnitudes and recurrence intervals. Rather, our reconnaissance results are intended to guide users to specific potential geohazards that will require additional study to determine the locations, slip rates, and movement histories of individual faults and fault segments (Carver and others, 2008a, 2010; Koehler and Carver, 2012; Koehler and Woods, 2013).

Five active faults, two possibly active lineaments (linear features in aerial photographs or in remotely sensed imagery and linear geomorphic features that could be faults but lack known evidence of Holocene movement), and a large, active, fault-propagation growth anticline (giant mole track) were identified during DGGS paleoseismic studies (fig. 53). The following discussion of active seismic structures is organized from west to east through the NFFTB. 


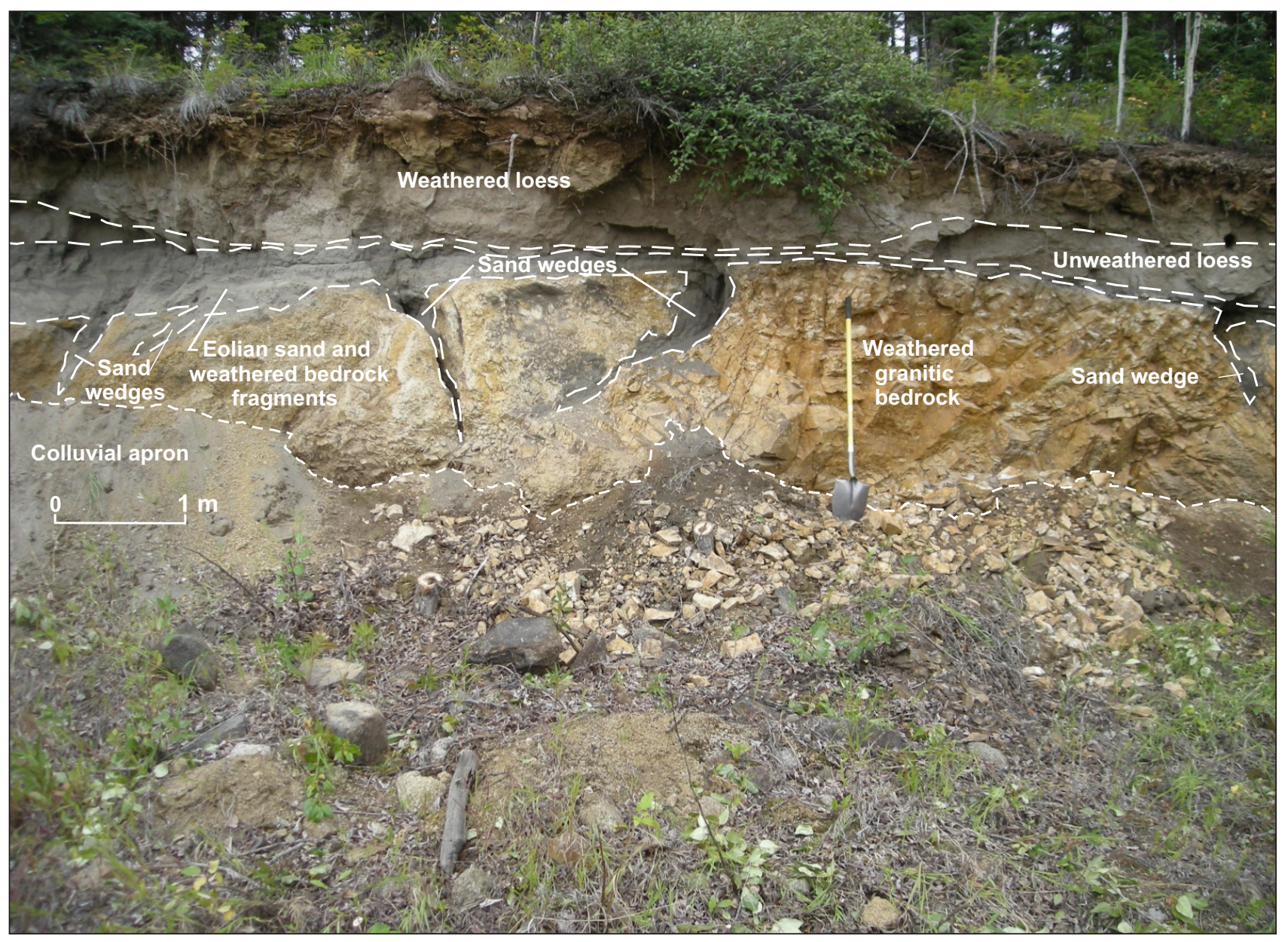

Figure 51. Sand wedges in weathered granitic bedrock formerly exposed in roadcut near AMP 1303.0, southeastern Tanacross B-4 Quadrangle (Reger and Hubbard, 2010, fig. 7). Yellow shovel handle is $1 \mathrm{~m}$ long. Photograph taken 8/1/2008.

\section{Granite Mountain-Panoramic fault}

The Granite Mountain fault was initially mapped as a northeast-trending, near-vertical rupture that offsets terminal moraines of the Delta and Donnelly glaciations downward to the northwest along the northwestern side of the Granite Mountain block (Péwé and Holmes, 1964; Holmes and Péwé, 1965). Carver and others (2008a) recognized that the northeast-trending, linear Panoramic fault vertically offsets late Pleistocene and Holocene alluvial surfaces 2 to $3 \mathrm{~m}$ in the lowland northwest of the Granite Mountain block, with the northwest fault block relatively upthrown (sheet 1 ). They connected the Donnelly Dome thrust fault with the Panoramic fault along the Granite Mountain fault (fig. 53). The Granite Mountain-Panoramic fault is now considered to be a leftlateral, strike-slip fault, one of several northeast-trending tear faults in the hanging wall of the regionally extensive, south-dipping Dot "T" Johnson thrust fault complex along the northern margin of the eastern Alaska Range (Carver and others, 2008a, b, 2010).

\section{Granite Mountain segment of Dot " $T$ " Johnson fault}

The Dot "T" Johnson (DTJ) thrust fault was first recognized during DGGS fault investigations as one of two main, gently south-dipping, multi-strand, segmented, active thrust faults in the NFFTB along the northern margin of the eastern Alaska Range in the upper Tanana River valley ${ }^{17}$ (Carver and others, 2008a, b, 2010) (fig. 53). The Dot " $T$ " Johnson fault is spatially divisible into western and eastern segments that are separated and offset by northeast-trending, left-lateral, strike-slip, tear faults. The western, Granite Mountain segment of the Dot "T" Johnson fault extends from the Panoramic-Granite Mountain fault at the northern corner of the Granite Mountain block southeastward $-17 \mathrm{~km}$ to the northeast-trending Canteen fault (fig. 53; sheet 2). A vertical fault strand along the steep northeastern margin of the Granite Mountain block dropped terminal moraines of the Delta and Donnelly glaciations vertically in the northeastern fault block, but did not displace them laterally (Holmes and Péwé, 1965). In 


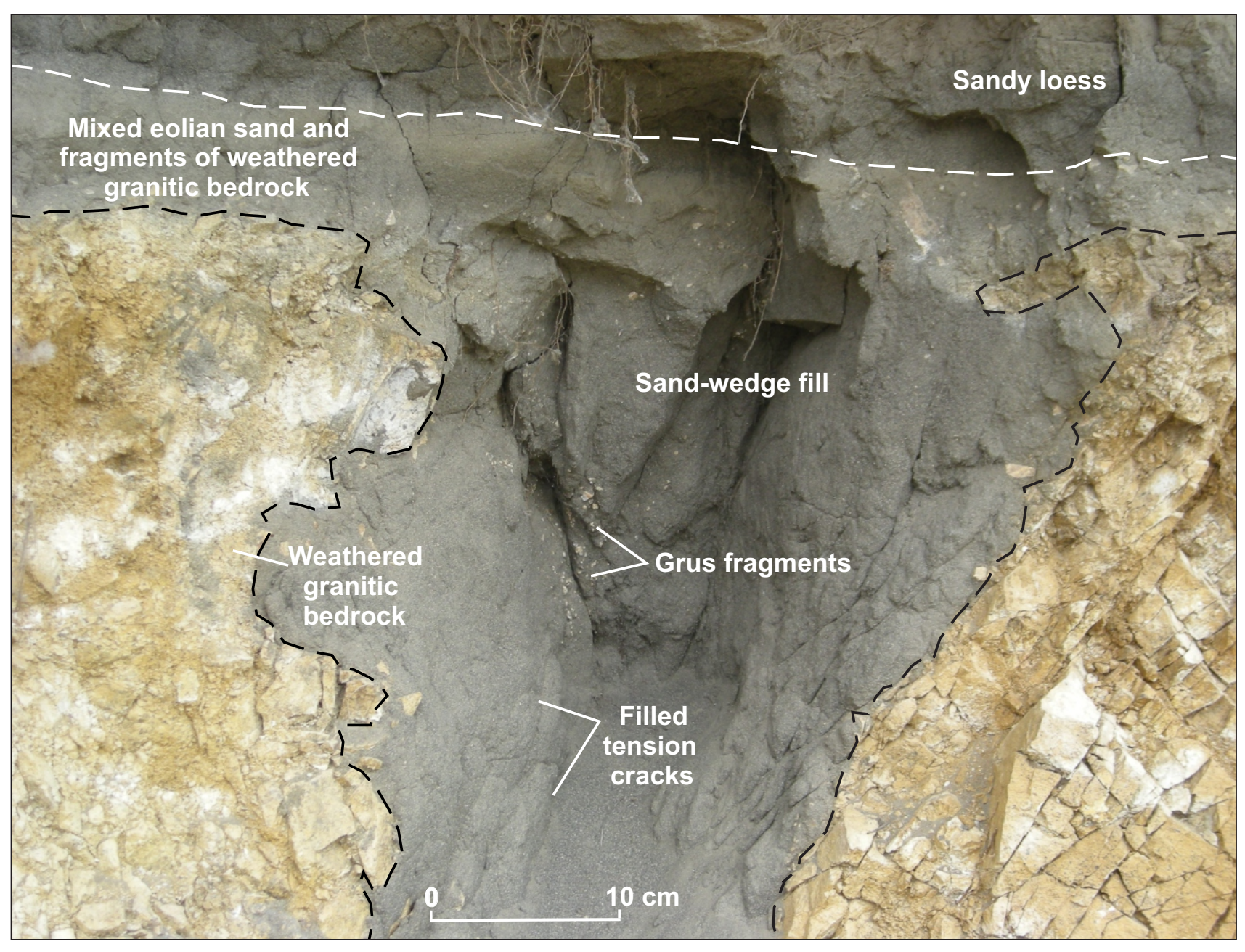

Figure 52. Sand-wedge filling of mixed eolian sand and angular fragments of weathered granitic bedrock in sand wedge in weathered granitic bedrock formerly exposed in roadcut near AMP 1303.0, southeastern Tanacross B-4 Quadrangle (Reger and Hubbard, 2010, fig. 8). Photograph taken 8/3/2008.

this segment, the Nenana Gravel of Pliocene age is draped in a steep monoclinal fold from the dissected Tertiary surface on the summit of the Granite Mountain block into the Tanana River valley west of the Gerstle River (Moffit, 1954; Carter, 1980; Carver and others, 2008a).

\section{Canteen fault}

From the west, the Dot "T" Johnson fault is first offset by the Canteen fault, a northeast-trending, left-lateral, strike-slip fault that connects the eastern end of the Granite Mountain segment of the Dot "T" Johnson thrust fault with the western end of the Dot Lake segment (fig. 53; sheet 2). Near the southwestern end of the Canteen fault (outside the study area), the western bedrock wall of Little Gerstle River valley, a Delta-age lateral moraine, and two sharp-crested lateral moraines of the Donnelly glaciation are offset by the Canteen fault (fig. 54). Post-Donnelly offset of $32 \mathrm{~m}$ indicates that the late Pleistocene-Holocene slip rate along the Canteen fault is $-1.6 \mathrm{~mm} / \mathrm{yr}$ (Carver and others, 2008a). Older slip rates are not well defined, but appear to be $-1.3-1.7 \mathrm{~mm} / \mathrm{yr}$. Eleven gouge cores were collected in a north-south strip through a pond and marsh in the fault zone at the offset of the older Donnelly lateral moraine, and a 2.5-m-long trench was hand dug to a depth of $-1 \mathrm{~m}$ across the fault zone $-20 \mathrm{~m}$ east of the marsh. Core sediments displayed at least two fault strands and evidence of several displacement episodes (Carver and others, 2008a, fig. 10). Six radiocarbon dates constrained the faulting events to younger than $-8 \mathrm{ka}$ and older than $1-4 \mathrm{ka}$. A stratigraphic record of at least three fault events was preserved in the trench across the Canteen fault zone, and seven radiocarbon dates provided maximum-limiting ages for those events between $4.7-4.9 \mathrm{ka}$ and $1.2-2.3 \mathrm{ka}$ (Carver and others, 2008a, fig. 11). 


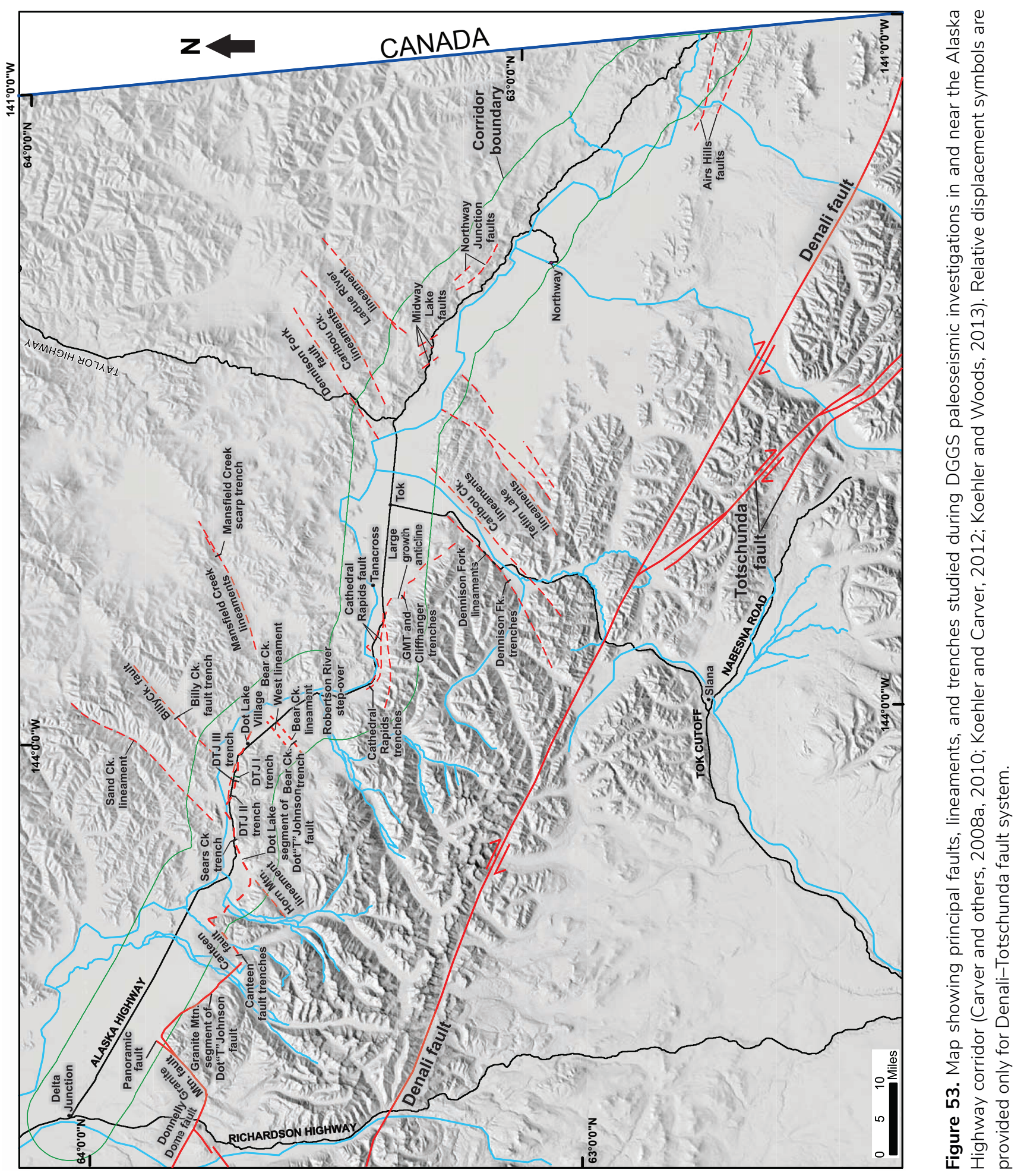




\section{Dot Lake segment of Dot "T" Johnson fault}

From the northeastern end of the Canteen fault at the north end of Independent Ridge, the Dot Lake segment of the Dot "T" Johnson fault extends $-8 \mathrm{~km}$ southeastward before curving and extending eastward $-25 \mathrm{~km}$ to the Bear Creek lineament (fig. 53; sheet 2). A small, thin, horizontal patch of Nenana Gravel represents a remnant of the high-level Tertiary surface at the north end of Independent Ridge (Holmes, 1965; Holmes and Foster, 1968; Carver and others, 2008a, fig. 4). In the field, the Dot "T" Johnson fault zone is recognized by the sublinear alignment of discontinuous scarps, truncated spur ridges, offset moraines, and vegetation lineaments along the northern base of the foothills of the Alaska Range (Carver and others, 2008a, b, 2010). Between Berry Creek and Dot Lake the fault forms a $\sim 1-\mathrm{km}$-wide, $10-\mathrm{km}$-long pop-up thrust wedge that is expressed at the surface as a well-defined mole track along the southern margin of a large, tilted, longitudinal flood bar (figs. 26 and 55).

In 2007, Carver and others (2008a) hand excavated Dot "T" Johnson trench I (DTJ I) across the prominent, steep, 2.5- to 4-m-high, south-facing moletrack scarp that crosses the dry channel of upper Sam Creek $-400 \mathrm{~m}$ south of the Alaska Highway (fig. 53; sheet 2). The trench was $-18 \mathrm{~m}$ long and 1.2 to $2.4 \mathrm{~m}$ deep. Trench walls exposed well-bedded fluvial sand and gravelly sand with interbedded loess layers and $\mathrm{a}-20^{\circ}$ south-dipping multi-strand thrust fault that terminated upward at two wedges of collapsed fault-tip colluvial rubble (fig. 56). The fault is associated with a very tightly overturned fault-propagation fold with the upper limb dismembered by the fault. Paleodisplacements up to at least $3 \mathrm{~m}$ were documented. Small chunks of detrital charcoal from the top of the lowest loess layer beneath the lower colluvial wedge in the west and east walls of the trench provide maximum-limiting ages for the earlier fault event of 12,780 cal. yr. B.P. (Beta-235569) (table 1, RC-18) and 11,910 cal. yr. B.P. (Beta 235574) (table 1, RC-19), respectively (Carver and others, 2008a, Appendix I). Charcoal chunks from the center of the loess layer overlying the lower colluvial wedge provide a minimum-limiting age of 12,180 cal. yr B.P. (Beta-235568) (table 1, RC 20) for that faulting episode. Charcoal fragments collected from the loess beneath the upper colluvial wedge in the east wall of trench DTJ I provide maximum-limiting ages for the later fault event of 9,640 cal. yr B.P. (Beta 235573) (table 1, RC-21) and 9,150 cal. yr. B.P. (Beta-235572) (table 1, RC 22).
About $4 \mathrm{~km}$ west of DTJ I trench and $75 \mathrm{~m}$ south of the Alaska Highway, a second trench (DTJ II) (fig. 53), measuring $3.5 \mathrm{~m}$ long and 1.2-1.8 $\mathrm{m}$ deep, exposed a south-dipping, low-angle backthrust of the Dot " $T$ " Johnson thrust fault (Carver and others, 2008a, figs. 18 and 19). Unfortunately, no datable material was recovered to limit the age of the faulting event there.

In 2008, Carver and others (2008a) mechanically excavated a 27-m-long trench (DTJ III) to a depth of $-3 \mathrm{~m}$ a distance of $-300 \mathrm{~m}$ west of trench DTJ 1 , where the mole track scarp transitions into a 4-m-high, southfacing, planar scarp (fig. 53; sheet 2). Trench stratigraphy, particularly in the hanging wall, was complex due to intense faulting and folding (fig. 57). The lower walls were composed of a three-package assemblage of flood sands with pebble and cobble basal lags, a sequence likely deposited in the flood channel along the south side of the longitudinal flood bar during late Donnelly jökulhlaups (Carver and others, 2008a; Reger and others, 2008a, fig. 20). Stratigraphically overlying the flood deposits were two folded and locally overturned sequences of thinly bedded silt, silty sand, and fine to very coarse sands that are interpreted to have been preserved in fault-bounded, detached fold noses above the main horizontal Dot "T" Johnson thrust fault. A collection of small detrital charcoal fragments from the deformed silt in the upper sequence provided maximum-limiting ages of $12,750 \mathrm{cal}$. yr B.P. (Beta-252293) (table 1, RC-5) and 11,300 cal. yr B.P. (Beta 252292) (table 1, RC-23) for the principal displacement along the Dot " $\mathrm{T}$ " Johnson fault (Carver and others, 2010). Several episodes of faulting are indicated by stratigraphic-bracketed upward terminations of secondary thrust faults and by cross-cutting relations between fault strands. The youngest faulting occurred more recently than 7,920 cal. yr B.P. (Beta-252294) (table 1, RC-24) (Carver and others, 2010).

In 2008, Carver and others (2008a) dug a 10-m-long trench across the Dot "T" Johnson fault with a trackmounted excavator $\sim 250$ m west of Sears Creek and -30 $m$ north of the Alaska Highway through a 2-m-high, north-facing fault scarp (fig. 53; sheet 2). The Sears Creek trench exposed poorly sorted, bedded, fine to medium, sandy and silty fluvial gravel containing lenses of wellsorted sand and well-rounded, fine, clast-supported gravel. The gravels are offset at the scarp by a single thrust fault that strikes $\mathrm{N} 15^{\circ} \pm 2^{\circ} \mathrm{E}$ and dips $15^{\circ} \pm 2^{\circ} \mathrm{S}$ (fig. 58). The amount of offset along the thrust fault was unclear, the

\footnotetext{
${ }^{17}$ The other principal thrust fault in the easternmost NFFTB is the Cathedral Rapids fault east of Robertson River and its associated large, fault-propagated growth anticline (Carver and others, 2010; Koehler and Woods, 2013).
} 
footwall lacked colluvial wedges, and no suitably positioned, datable materials were found to date the faulting event. However, the lack of a soil profile in the fluvial sediments indicates that they are Holocene in age. Carver and others (2008a) estimated that the $2 \mathrm{~m}$ scarp height was the result of $-7.7 \mathrm{~m}$ of fault displacement since the terrace sediments were deposited.

These exploratory trenches document considerable evidence for at least one latest Pleistocene and one Holocene earthquake. Initial estimates of recurrence intervals for surface and near-surface faults in the eastern NFFTB, based on radiocarbon dating of fault-disrupted and folded layers, range from $-2,000$ to $-3,000$ years but could be considerably longer (Carver and others, 2008a).

\section{Billy Creek fault}

North of the Tanana River and just outside the Alaska Highway corridor, the Billy Creek fault extends for $>35$ $\mathrm{km}$ through the southern Yukon-Tanana Upland (fig. 53). Field evidence for the Billy Creek fault includes discontinuous aligned linear scarps, prominent vegetation lines and boundaries, and linear streams (Carver and others, 2008a). Along the southwestern part of the fault, spur ridges trending orthogonal to the fault exhibit left-lateral offset across 3-m-high scarps. In 2007, Carver and others (2008a, fig. 7) hand excavated a 5-m-long trench across a 2.5-m-high, southeast-facing scarp. The 1.2- to 2-m-deep trench exposed bedrock beneath the scarp face and three cobbly colluvial wedges extending downslope from the bedrock. The coarse colluvial wedges were separated by layers of sandy slopewash colluvium. At least three fault strands were exposed in the trench. No datable organic material was encountered in the trench, but weak soil development and the lack of periglacial reworking of the colluvium exposed in the trench imply that faulting is probably Holocene.

\section{Bear Creek lineament}

A sizeable gap in our knowledge of active seismic structures in the NFFTB exists in the Robertson River stepover between the eastern limit of the Dot Lake segment of the Dot "T" Johnson fault and the western limit of the Cathedral Rapids fault (Carver and others, 2010) (fig. 53). In this gap, there is $-32 \mathrm{~km}$ of offset in the eastern Alaska Range and the NFFTB. One candidate for an active connecting fault in the Robertson River stepover east of Bear Creek is the northeast-trending Bear Creek lineament, which coincides with a linear, west-facing

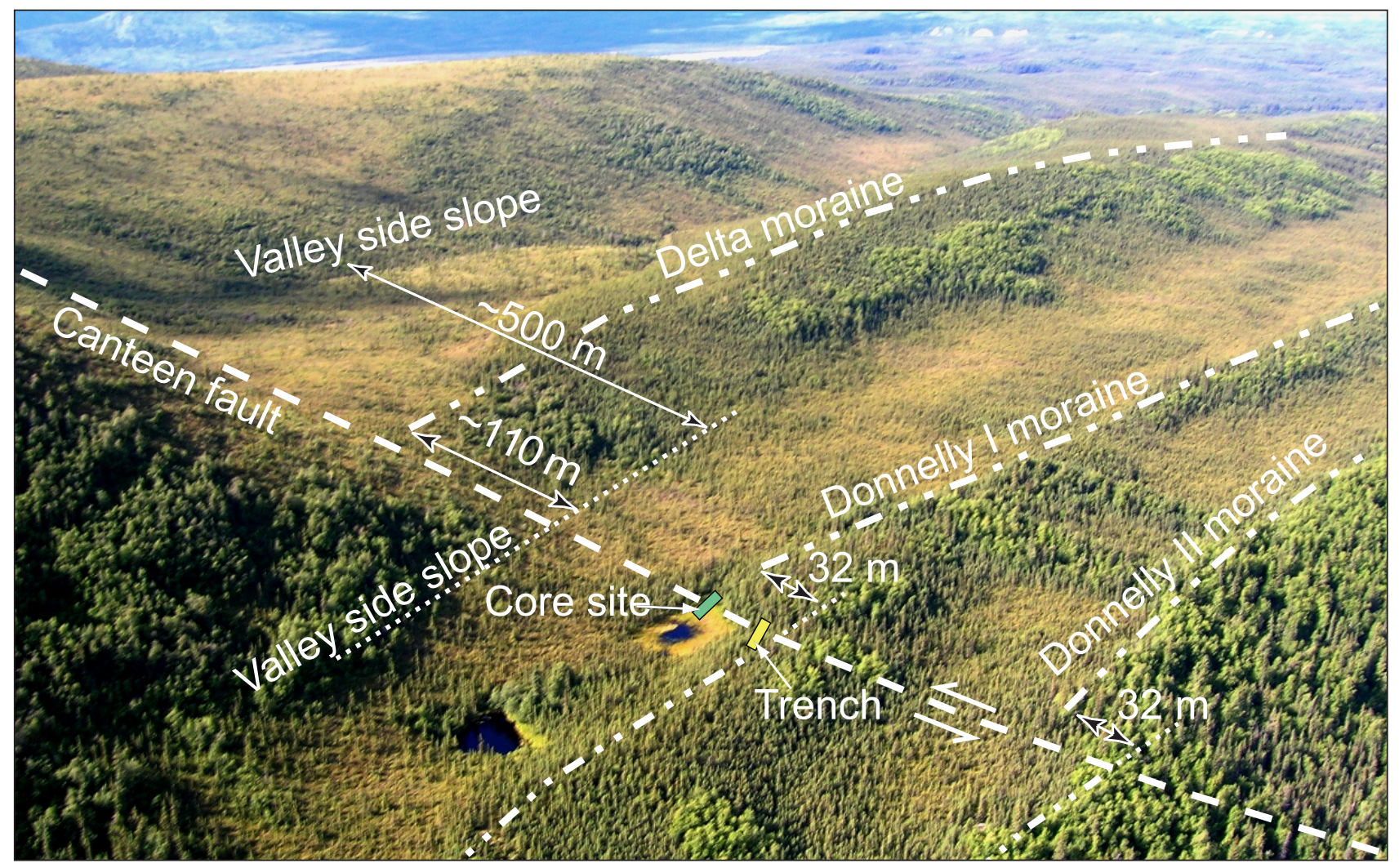

Figure 54. Oblique aerial photograph toward northwest of Donnelly and Delta lateral moraines offset by left-lateral Holocene movements along Canteen fault, northeastern Mount Hayes C-3 Quadrangle (Carver and others, 2008a, fig. 8). 
scarp between the Donnelly terminal moraine of the Robertson River lobe and a Donnelly outwash terrace in the Bear Creek drainage (Carver and others, 2010, fig. 12). However, several trenches across the lineament did not expose conclusive evidence of active faulting (Carver and others, 2010; Bemis and others, 2012).

\section{Cathedral Rapids fault}

From Sheep Creek to the vicinity of Moon Lake the Cathedral Rapids thrust fault extends $-21 \mathrm{~km}$ as a pair of subparallel, south-dipping, imbricate strands responsible for north-facing scarps up to $30 \mathrm{~m}$ high across the steep piedmont apron of Delta and Donnelly terminal moraines, outwash fans, and colluvial-alluvial fans along the base of the steep north flank of the eastern Alaska Range (Reger and others, 2011, sheet 2) (fig. 53; sheet 4). Subparallel to the southern fault trace and across the lower bedrock valley wall to the south, the Range Front fault is interpreted to be a large, moment-bending rupture in a fault-bend anticline (Carver and others, 2010) or a third subparallel strand of the Cathedral Rapids thrust fault (Koehler and others, 2010; Koehler, 2011; Koehler and Woods, 2013).

To assess the paleoseismic history of the northern strand of the Cathedral Rapids fault, two trenches ( $\mathrm{T} 1$ and $\mathrm{T} 2$ ) were excavated across the 2.5-m-high scarp close to the Alaska Highway (fig. 59; sheet 4). The side walls of trench $\mathrm{T} 1$ revealed a basal, matrix-supported gravel diamicton with subangular to subrounded clasts arranged in a cobbly upper layer and a bouldery lower layer (unit 1 in fig. 60). This diamicton was crudely bedded with the layering in the southern part of the trenches parallel to the slope above the trench and the bedding and imbrication of cobbles in the northern part of the trench parallel to the face of the scarp. A subtle interbed in the diamicton contains boulders up to $1 \mathrm{~m}$ diameter and appears to be folded downward. Several weathered clasts and deformed sand lenses that likely resulted from dewatering of a debris

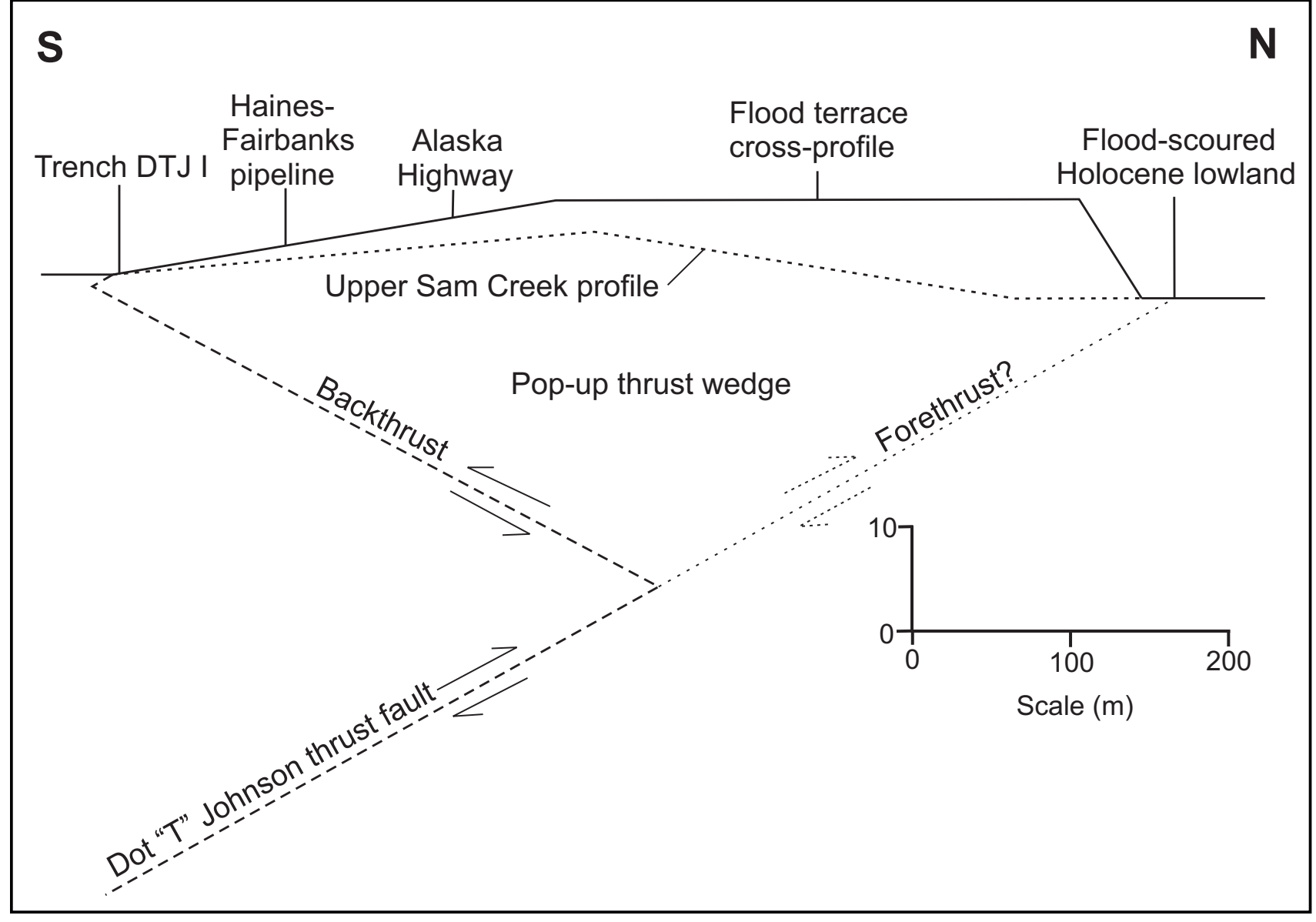

Figure 55. Profiles of deformed longitudinal flood bar and floor of upper Sam Creek valley related to structural model for popup thrust wedge on Dot "T" Johnson fault at trench site DTJ I, northeastern Mount Hayes C-1 Quadrangle (after Carver and others, 2008a, fig. 13). Vertical exaggeration $\sim 7$. 


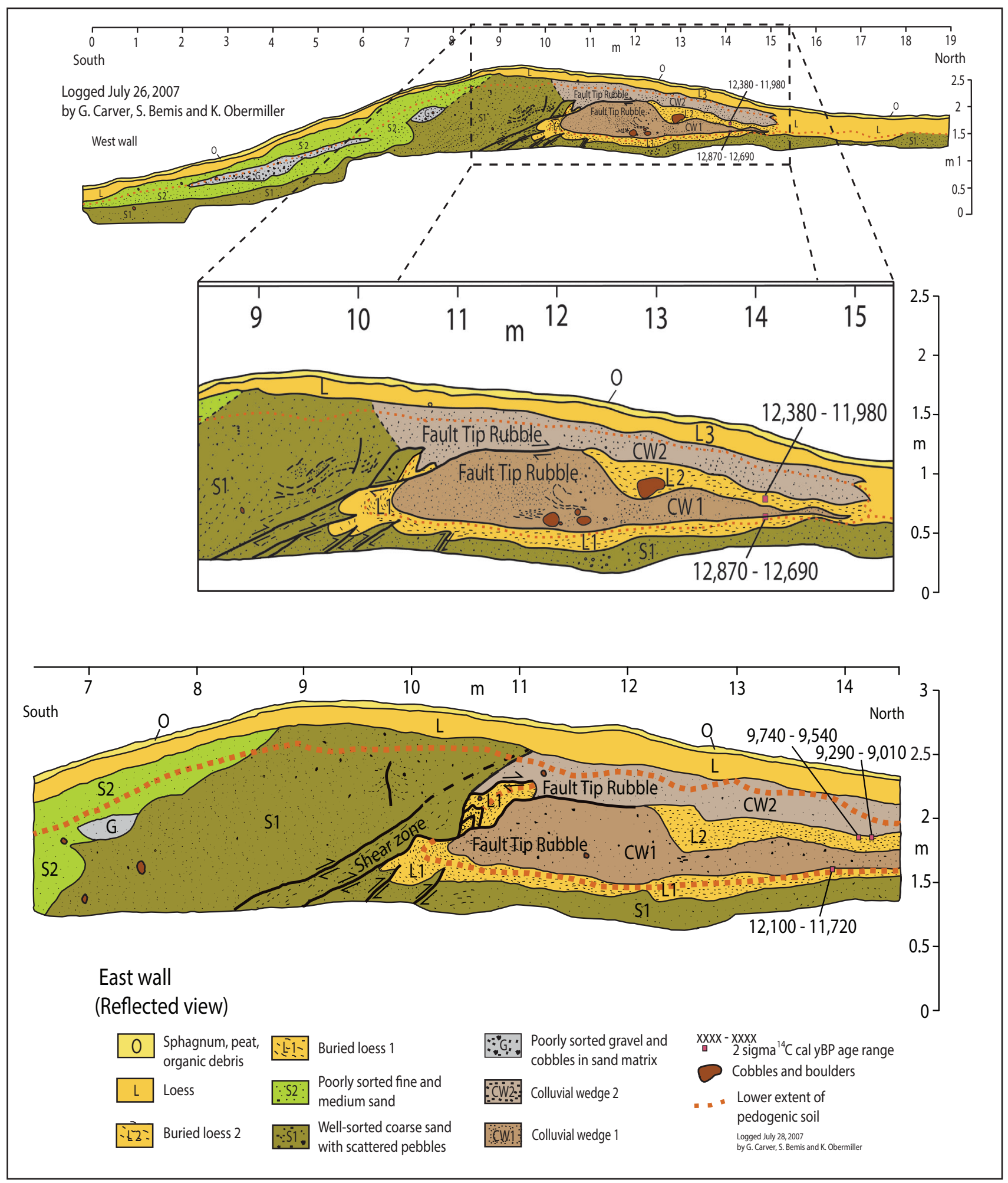

Figure 56. Stratigraphic logs of east and west walls in trench DTJ I dug across mole track scarp on Dot "T" Johnson backthrust, northeastern Mount Hayes C-1 Quadrangle, indicating a near-surface, shallow-dipping thrust fault (Carver and others, 2008a, fig. 14). Radiocarbon ages in calibrated years BP. 


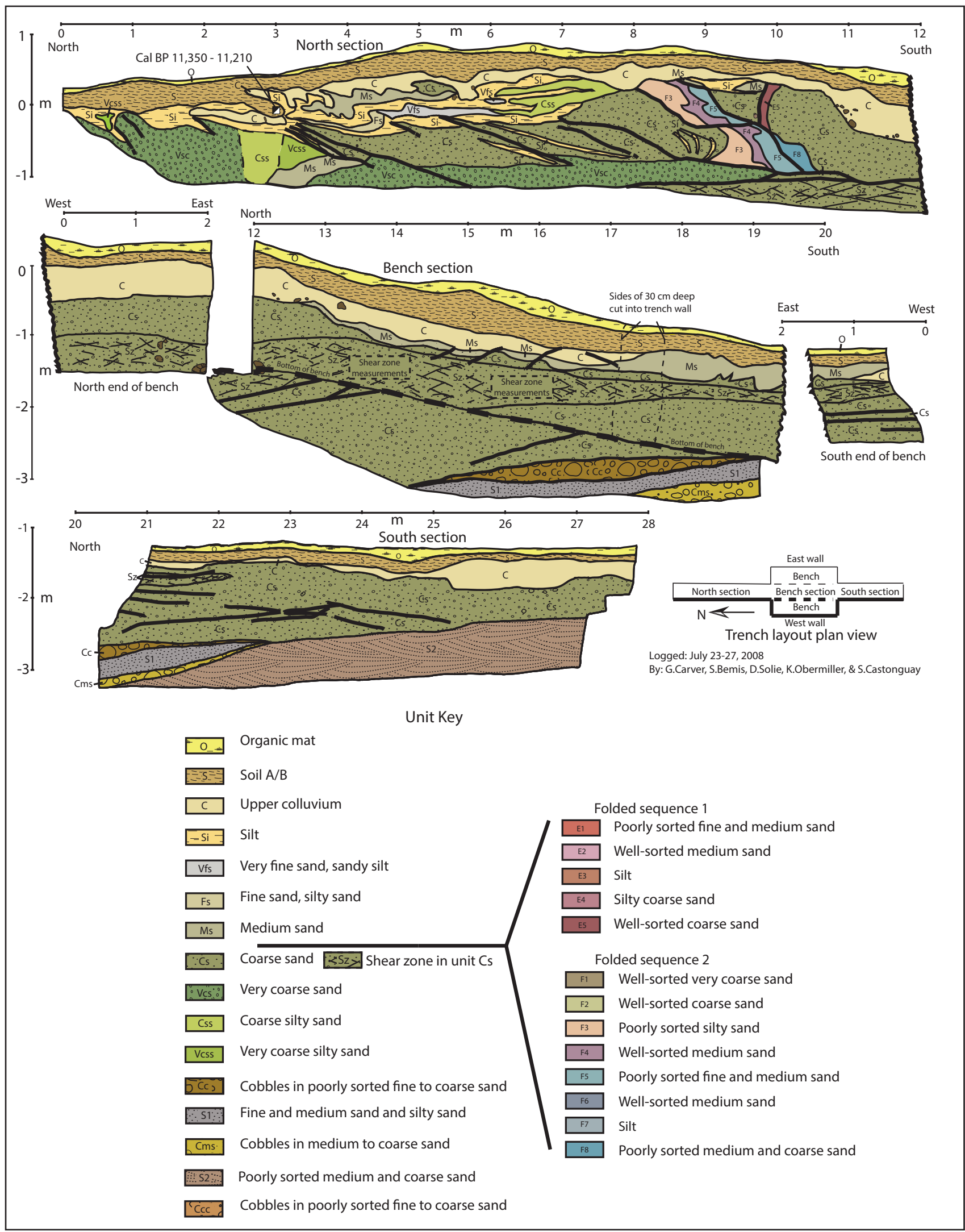

Figure 57. Stratigraphic logs of east and west walls in trench DTJ III, northeastern Mount Hayes C-1 Quadrangle, showing thrust faults and shears (Carver and others, 2010, fig. 9). 
flow indicate that the diamicton is derived from the Delta drift upslope (sheet 3).

A younger alluvial sequence was exposed above the diamicton in the northern 7-8 $\mathrm{m}$ of both walls of trench $\mathrm{T} 1$. The lowest layer in this sequence (unit 2 in fig. 60) consisted of interbedded nonmicaceous fine sand and clay layers that dipped $17-24^{\circ} \mathrm{N}$ parallel to the scarp face before becoming horizontal beneath the fluvial terrace at the base of the scarp. A prominent buried soil represented an unconformity at the top of unit 2 . Detailed mapping indicates that the unconformity is deformed upward against the scarp face. Three radiocarbon dates demonstrate that unit 2 was deposited between 3,510 \pm 40 RC yr B.P. (3,790 cal. yr B.P.) (Beta-292212) (table 1, RC-25) and $930 \pm 30$ RC yr B.P. ( 850 cal. yr B.P.) (Beta 292211) (table 1, RC 26). Overlying the soil were horizontally bedded, interlayered micaceous alluvial sands and silts containing incipient soil profiles (unit 3 in fig. 60), which Koehler and Woods (2013) interpreted to represent slackwater sediments deposited by the Tanana River during episodic Holocene flooding after deposition of unit 2 and formation of the scarp. A meter-thick alluvial gravel (unit 4, not shown in fig. 60), which was locally derived from a small fan to the west of trench $T 1$, was exposed above unit 3 only in the west wall of the trench. A submeter layer of loess (unit 5 in fig. 60) capped the alluvial sequence in both side walls.

No faults, shear zones, or offset beds were observed in either trench. Koehler and Woods (2013) attributed the origin of the linear scarp to folding related to movement along the Cathedral Rapids thrust fault, which did not reach the ground surface but is present at depth (blind) in this area, and minor Holocene erosion by the flooding Tanana River. This model implies that the unconformity at the top of unit 2 was warped upward during one or more scarp-forming earthquakes that occurred after formation of the soil related to that unconformity (after $970 \pm 30$ RC yr B.P.) (Beta-292210) (table 1, RC-27) and before the deposition of unit 3. Worldwide, there are many examples of surface folding and scarp formation by blind thrust faults (Meghraoui and others, 1988; Kelson and others, 2001; Nelson and others, 2003).

East of Moon Lake, the northern strand of the Cathedral Rapids fault extends another $20 \mathrm{~km}$ across late Pleistocene and Holocene fluvial and glaciofluvial alluvium, colluvium, and colluvial-alluvial fans (sheets 3 and 4 ). The southeastern $-16 \mathrm{~km}$ of this trace is associated with a prominent large, sinuous, thrust-fault-propagation growth anticline (giant mole track anticline of Carver and others, 2010) (fig. 61, cover photo).

\section{Prominent growth anticline}

Earlier geologic maps identified the prominent sinuous, southeast-trending, discontinuous ridge that stands up to $70 \mathrm{~m}$ high along the base of the piedmont slope southwest of Tanacross as moraine of the Delta glaciation (Foster, 1970), landslide deposits (Carter and Galloway, 1978), and a series of bedrock knobs (Carrara, 2004b) (sheet 4). Field evidence does not support these interpretations, and the location and composition of the feature rule out an origin related to the major Donnelly jökulhlaups that deposited the Tok expansion fan to the east (Carver and others, 2010). The presence of deeply incised canyons occupied by small drainages between the ridges of the feature is evidence that the ridges postdate the antecedent piedmont drainage (Carver and others, 2010).

To determine if the origin of the anticlinal ridge is related to active faulting, Carver and others (2010) investigated stream terraces that appeared to be deformed across the ridge along one of the piedmont drainages, informally named "Catastrophe Creek" (figs. 61 and 62). Their studies included detailed mapping of the local landforms and differential GPS surveys of several longitudinal profiles of terraces and the modern stream thalweg across the ridge. Carver and others (2010) also documented the stratigraphy in a trench and in an excavated natural exposure across the main strand of Cathedral Rapids fault. Along Catastrophe Creek they recognized six raised terraces (fig. 62). One of the older terraces (T4) is well preserved and is clearly deformed across the anticlinal ridge. The tread of terrace T4 is distinctly tilted upstream where the profile crosses the anticlinal ridge and is raised relative to the modern stream profile. Downstream from a prominent fold hinge, the profile of terrace T4 is backtilted, indicating that the geometry of the underlying Cathedral Rapids fault plane becomes more horizontal (forms a listric ramp) as the fault plane approaches the ground surface (Carver and others, 2010, p. 21). Downstream from the backtilted surface, the terrace tread gradually steepens toward another fold hinge, where it abruptly descends downstream on the north-facing forelimb of an anticline and on a scarp (fig. 62). Clearly, the surface of terrace T4 was folded to form the anticline and scarp, indicating that fault movement occurred after the terrace formed.

In the Cliffhanger trench excavated into the natural bank exposure on the northwestern side of Catastrophe Creek, two small grabens were exposed near the crest of the fault-generated fold. The grabens are filled with fault-disrupted, fine-grained sediments, buried soils, 


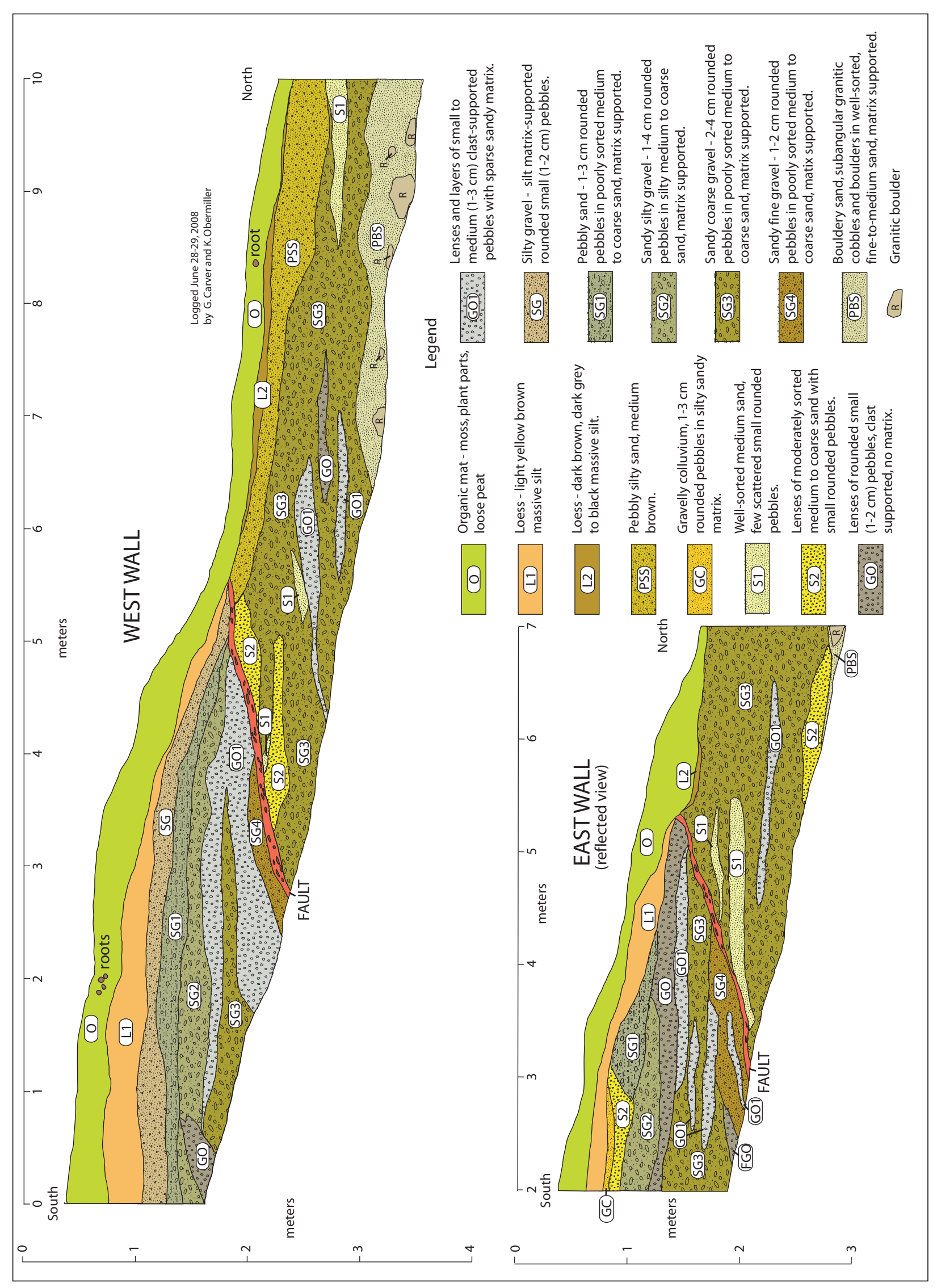

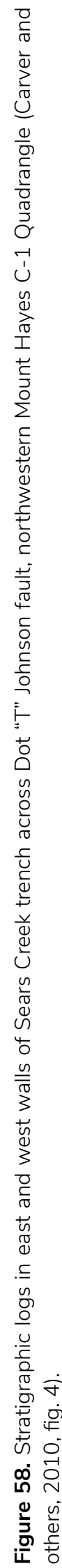


and colluvium (Carver and others, 2010, fig. 20), and likely developed to accommodate extension at hinges in the anticline crest during coseismic folding as a result of thrusting along the underlying Cathedral Rapids fault. At least five latest Pleistocene/Holocene earthquakes are interpreted from upward-terminating faults in the graben fill (Carver and others, 2010, p. 22).

Carver and others (2010, fig. 24) excavated trench GMT I on the southeastern side of Catastrophe Creek through a gently sloping $2 \mathrm{~m}$-high scarp that deforms a young stream terrace. The trench was sited at the west end of a 1-m-high, locally steeper, discontinuous, planar facet near the center of the gentle scarp face. The excavation exposed (1) an upper, 20- to 30-cm-thick, near-surface layer of surface and subsurface organics interbedded with thin, well-sorted, medium fluvial sands, (2) an intermediate 40to 70 -cm-thick stratified colluvium with thin, local lenses and beds of fluvial sand containing discontinuous thin streaks of very-fine-grained black organics and charcoal, and (3) a frozen basal unit consisting of two bouldery colluvial layers (fig. 63). The bedding generally parallels the ground surface, even on the scarp face. The eastern and western trench walls exposed a single thrust fault that offsets the colluvial layers but not the near-surface fluvial sands and organic layers. The preferred interpretation is that the gently sloping scarp (surface fold) formed after deposition of the surface fluvial sands during a single episode of movement along the underlying, generally blind, south-dipping Cathedral Rapids thrust fault (Carver and others, 2010, p. 28). Two samples of detrital wood associated with the youngest colluvial unit offset by the fault provided modern ages of $160 \mathrm{cal}$. yr B.P. (Beta-252302) (table 1, RC-30) and 150 cal. yr B.P. (Beta 252301) (table $1, \mathrm{RC}-31$ ), indicating that the latest displacement on this segment of the Cathedral Rapids thrust fault occurred after -1650 A.D. Geometric relations imply that $-4 \mathrm{~m}$ of dip-slip displacement occurred at depth during the event (Carver and others, 2010, p. 28).

DGGS paleoseismic investigations indicate that the easternmost active thrust fault related to the NFFTB in the eastern Alaska Range is the Cathedral Rapids fault. These investigations did not find evidence of the Cathedral Rapids fault between the large, fault-propagation growth anticline ridge and the Denali and Totschunda faults to the south (fig. 53) (Carver and others, 2010; Koehler and Carver, 2012).

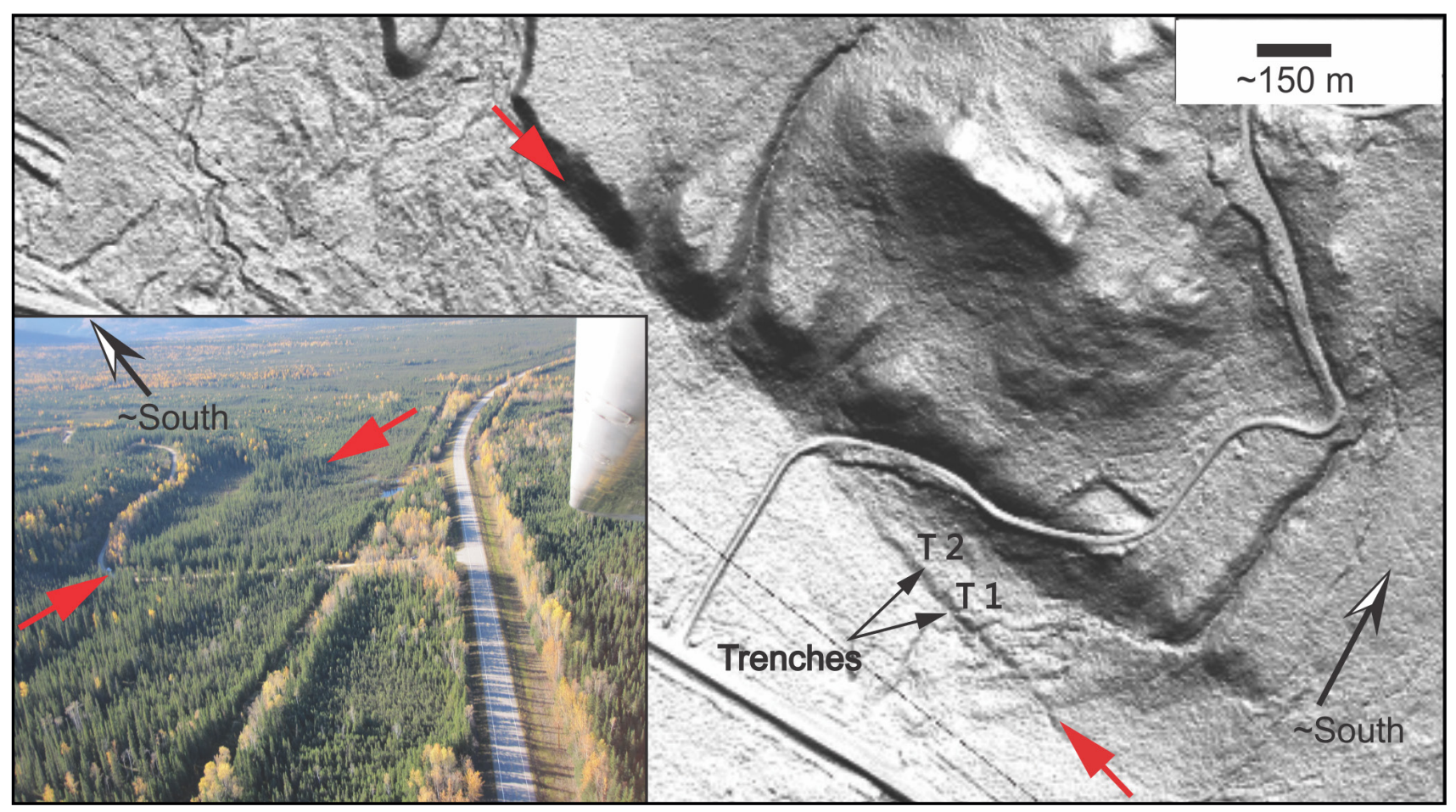

Figure 59. Lidar image and oblique aerial photograph (inset) of scarp along Cathedral Rapids fault (between red arrows), showing locations of trenches T 1 and T 2, north-central Tanacross B-6 Quadrangle (Koehler and Woods, 2013. fig. 9). 


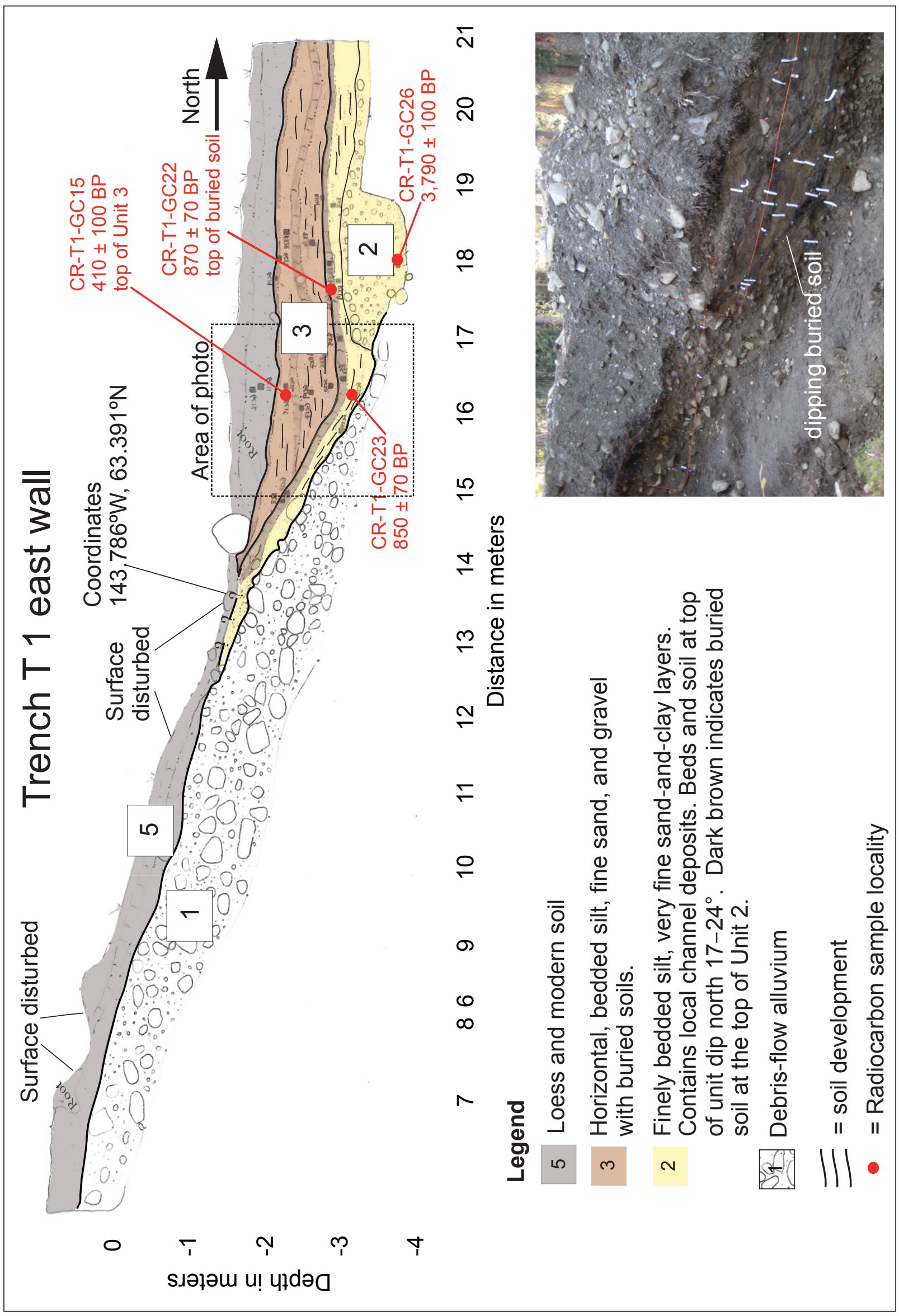




\section{Inactive faults and lineaments}

DGGS also investigated several other linear features, which have been suggested as possible active seismic structures in published reports (Brogan and others, 1975; Plafker and others, 1994) and in unpublished proprietary reports, but did not confirm Holocene activity (fig. 53). Where these inactive faults and lineaments are present in the Alaska Highway corridor, their locations are shown on the accompanying surficial-geologic maps. Otherwise, additional information about each feature exists in the reports that describe the DGGS evaluations (Carver and others, 2008a, 2010; Koehler and Woods, 2013).

\section{Horn Mountain lineament}

Nearly aligned with the Sand Creek lineament (fig. 53), the Horn Mountain lineament on the Macomb Plateau south of the Tanana River coincides with a linear aeromagnetic anomaly and the straight, southeastern limit of the Usibelli Group, a sequence of Oligocene-Miocene, nonmarine, coal-bearing sedimentary rocks preserved in a small, down-faulted block on the plateau (Carver and others, 2008a, fig. 4). Field mapping demonstrates that the lineament coincides with a zone of mylonitic and recrystallized granitic bedrock that is not associated with a scarp, but is interpreted as an older, inactive fault associated with uplift of the plateau (Carver and others, 2008a).

\section{Sand Creek lineament}

North of the Tanana River, the northeast-trending, linear valley of Sand Creek, which is associated with a series of subparallel to parallel scarp-like features on the noses of bedrock ridges, coincides with a prominent linear vegetation boundary and prominent linear features on published aeromagnetic and electromagnetic maps (fig. 53). However, surface profiles surveyed in the field demonstrate that the ridge crests are not vertically offset, and field reconnaissance did not identify a scarp along the

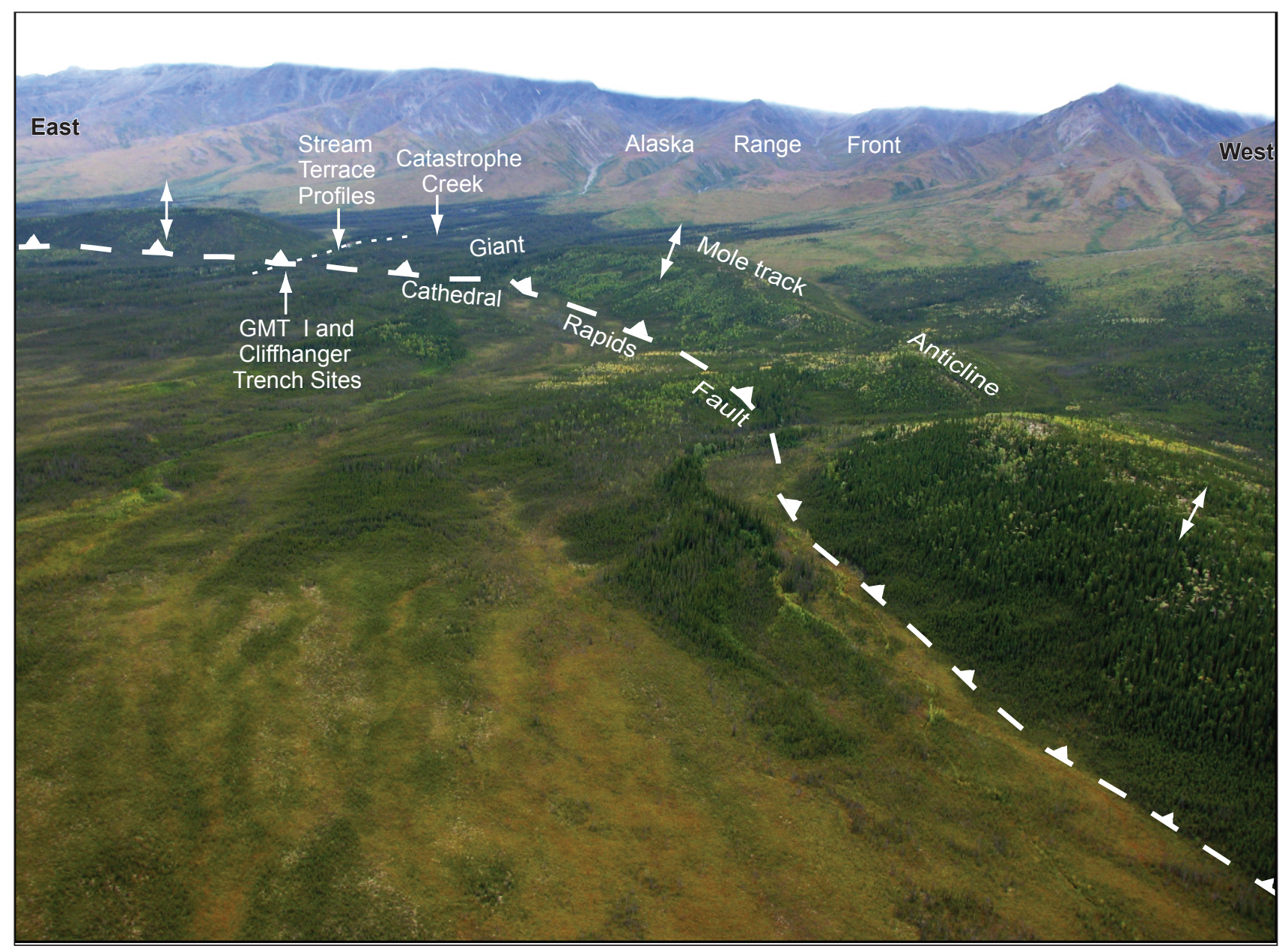

Figure 61. Oblique aerial photograph looking southeastward at northwestern segment of large fault-propagated growth anticline along base of piedmont slope, and showing locations of surveyed stream-terrace profiles and trench sites along "Catastrophe Creek", southwestern Tanacross B-5 Quadrangle (Carver and others, 2010, fig. 15). 
linear vegetation boundary or offsets of Holocene alluvial fills (Carver and others, 2008a, figs. 23 and 24). Surface lineaments are believed to result from differential erosion along inactive shear zones in the bedrock.

\section{Bear Creek West lineament}

The Bear Creek West lineament was initially identified on low-altitude black-and-white aerial photographs as a northeast-trending photo lineament crossing the Alaska Highway -800 m west of Bear Creek. Field reconnaissance revealed that the photo lineament, which parallels the Bear Creek lineament on the other side of Bear Creek, coincides with a 0.5 -m-high, west-facing scarp on a gently sloping surface of Donnelly gravel outwash overlain by 10 to $25 \mathrm{~cm}$ of loess (Carver and others, 2008a) (fig. 53). However, a small exploratory trench across the scarp was limited by shallow permafrost and revealed no stratigraphy suitable for evaluating the presence or absence of an active fault.

\section{Mansfield Creek lineaments}

These discontinuous lineaments include several northeast-trending linear changes in vegetation, hillside scarps up to $10 \mathrm{~m}$ high, changes of slope, and aligned springs in the valley of Mansfield Creek north of the Alaska Highway corridor (fig. 53). Carver and others (2010, fig. 3) hand dug a single trench across an obvious 1.5 -m-high, southeast-facing scarp on the most prominent continuous lineament $-4.8 \mathrm{~km}$ north-northeast of Mansfield Lake. The trench walls revealed no evidence of a fault in the quartzite and schist bedrock or the thin, overlying colluvium, and the scarp was interpreted to be the product of differential erosion of the pervasively weathered bedrock (Carver and others, 2010, fig. 29).

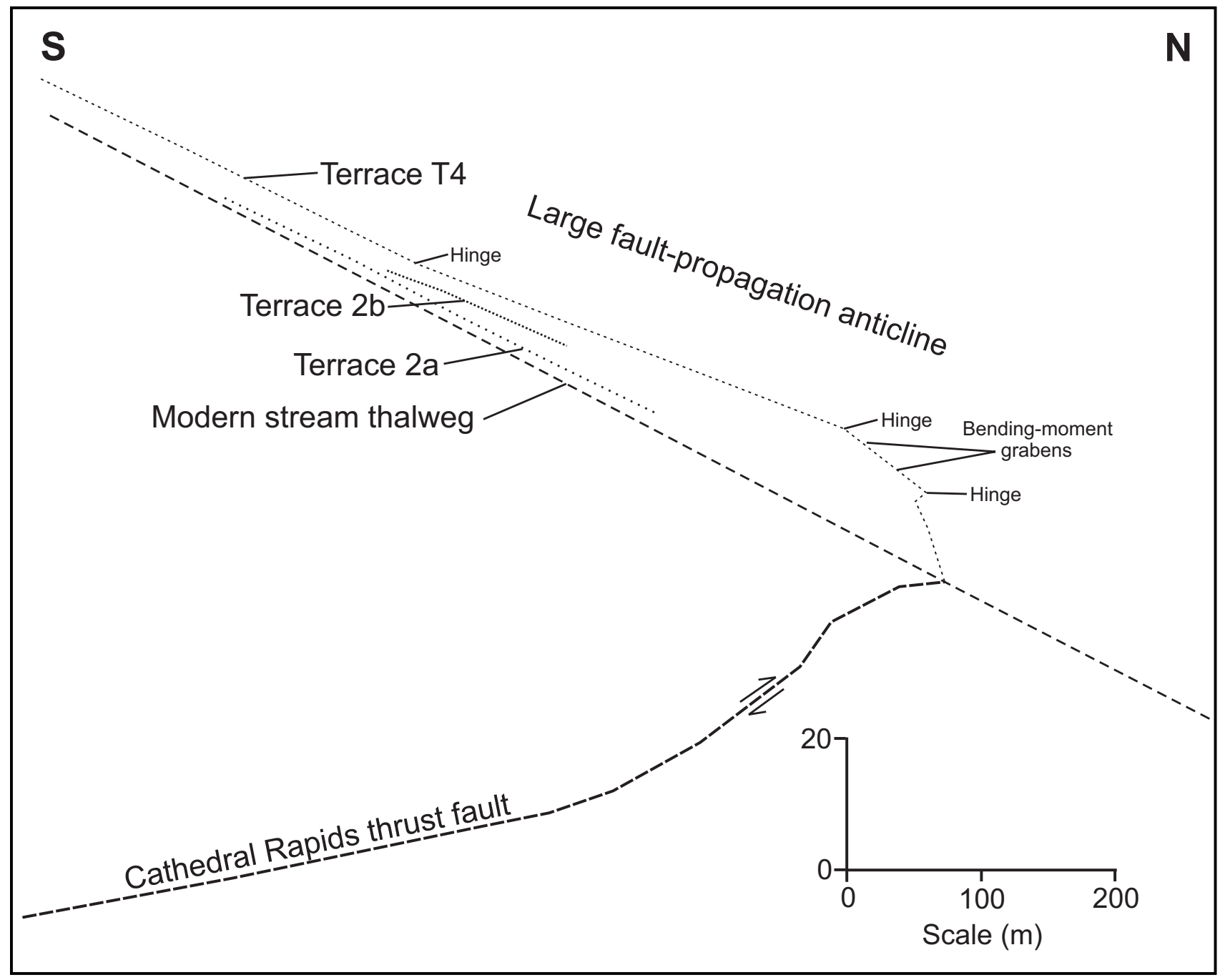

Figure 62. Differential GPS longitudinal profiles of modern thalweg of Catastrophe Creek and deformed fluvial terraces across large, fault-propagated growth anticline and Cathedral Rapids fault scarp, southwestern Tanacross B-5 Quadrangle (after Carver and others, 2010, fig. 17). Vertical exaggeration 8. 


\section{Dennison Fork and Caribou Creek lineaments}

These linear features are parallel, northeast-trending, discontinuous, linear escarpments and lineaments that are spaced -4 to $9 \mathrm{~km}$ apart along the margins of the Tok River valley and extend into the southern Yukon-Tanana Upland (fig. 53). Carver and others (2010) mechanically excavated and logged the stratigraphic relations in two closely-spaced trenches across a prominent scarp along the Dennison Fork lineament in the upper Tok River valley and concluded that the scarp does not represent a fault scarp as previously interpreted (Plafker and others, 1994), but was cut by Donnelly jökulhlaups and modified by Holocene floods. Although the Caribou Creek lineament along the base of the opposite valley wall was not trenched during their investigation, Carver and others (2010) reviewed descriptions of subsurface stratigraphy in earlier unpublished reports and interpreted the Caribou Creek lineament (p. 33) as a second jökulhlaup erosion scarp. Based on observations made during a later, brief field visit and reconsideration of trench stratigraphy reported in previous consulting reports, Koehler and Carver (2012) supported a nontectonic, flood origin for the Dennison Fork and Caribou Creek linear scarps in the Tok River valley.

North of the Alaska Highway corridor in the southern Yukon-Tanana Upland, the Dennison Fork lineament is delineated in the valley of the Dennison Fork by

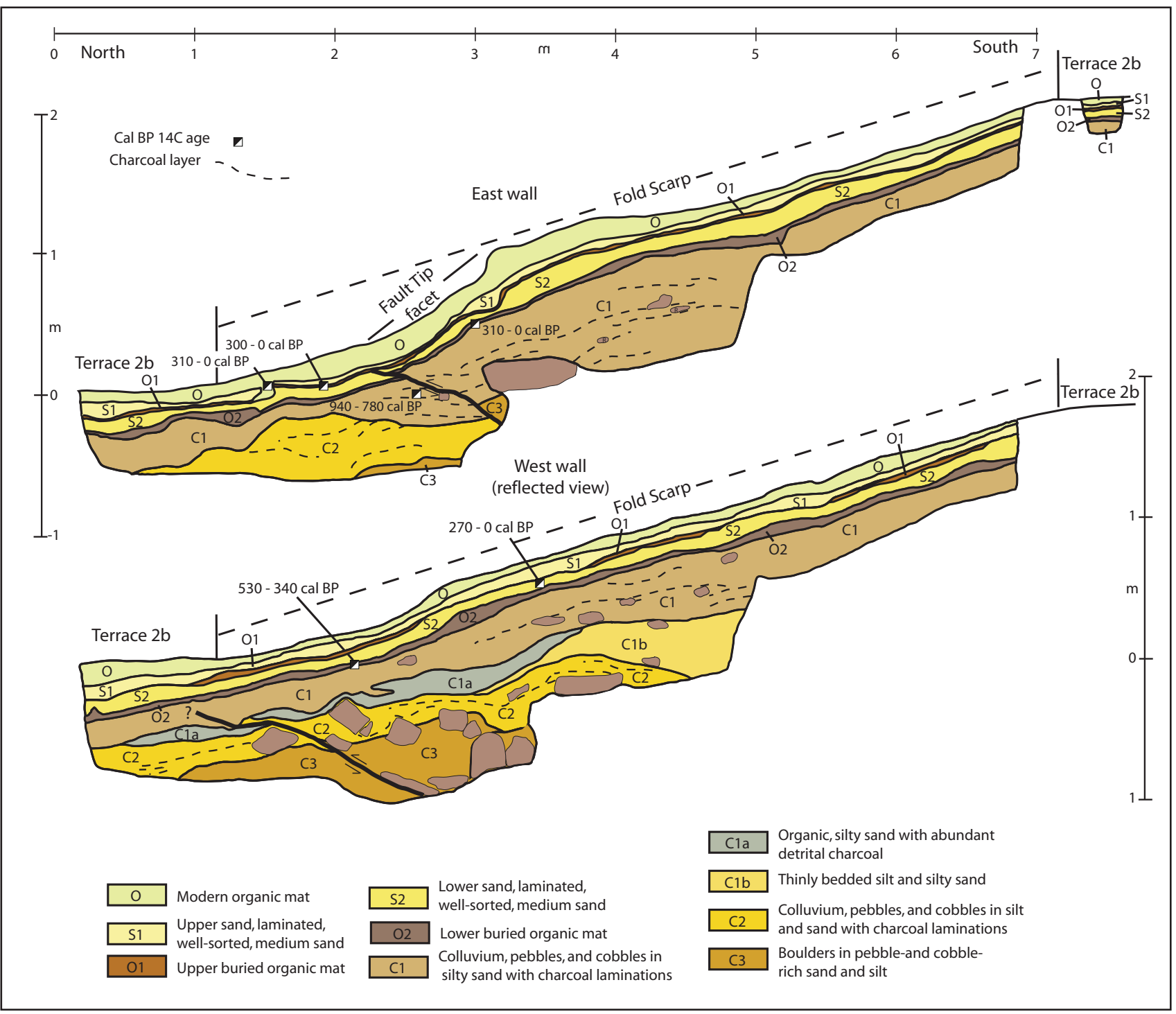

Figure 63. Stratigraphic logs of east and west walls in trench GMT I across Cathedral Rapids fault along base of large, faultpropagated anticlinal ridge, southwestern Tanacross B-5 Quadrangle (Carver and others, 2010, fig. 26). 
aligned vegetation contrasts, subtle linear topographic changes, discontinuous but obvious scarps and benches, and aligned springs and open-system pingos (Koehler and Carver, 2012). After a helicopter reconnaissance that did not identify any surface evidence for faulting in the Dennison Fork valley, Koehler and Carver critically reevaluated the unpublished log that previously reported several faults in granitic bedrock in a trench across the Dennison Fork lineament. The Dennison Fork fault was not recognized during several years of bedrock mapping in the Tanacross Quadrangle by Foster (1970). Among several challenges to an interpretation favoring Holocene faulting are the lack of cutting of near-surface strata by faults and the lack of offset of any of the layers depicted in the original trench log (Koehler and Carver, 2012, p. 8). An alternative, viable explanation for alternating layers of silt and buried soils depicted in the soil log is the burial of soils by an episodic Holocene rain of loess and volcanic tephra rather than episodic left-lateral offset and surface faulting, as originally suggested. In addition, surface features such as terrace risers are not laterally offset along the lineament in the site map, which is inconsistent with the previously proposed occurrence of multiple Holocene surface-breaking faulting events. The latest interpretation of the trench log is that the stratigraphy is the result of deposition and does not document Holocene surface-rupturing earthquakes (Koehler and Carver, 2012, p. 8).

In the southern Yukon-Tanana Upland, the Caribou Creek lineament is interpreted to follow aeromagnetic anomalies (Griscom, 1976), and is expressed at the surface as hillside benches, aligned saddles, alignments of springs and open-system pingos, truncated valleys, linear vegetation contrasts and drainages, and left-laterally-displaced ridge crests (Koehler and Carver, 2012). However, Foster (1970) did not recognize an active Caribou Creek fault during extensive field mapping in the vicinity. Following a helicopter-supported field reconnaissance, including ground surveys, along the mapped trace of the Caribou Creek fault, Koehler and Carver (2012) critically reviewed the field evidence cited in unpublished, proprietary reports. Either the previously cited field evidence could not be confirmed or explanations other than faulting were favored for almost all features previously attributed to Holocene surface faulting. The presence of extensive hydrothermal quartz crystals and healed brecciation along the fault trace indicates that the Caribou Creek lineament represents an old, inactive bedrock fault and the subtle features intermittently present along the fault are fault-line erosional features in the upland (Koehler and Carver, 2012).

\section{Tetlin Lake lineaments}

Five northeast-trending lineaments south of the Alaska Highway corridor were mapped in a published map and in unpublished proprietary reports along several aeromagnetic anomalies (Griscom, 1976), including two strike-slip faults mapped in the field southwest of Tetlin Lake by Foster (1970), and subtle, linear vegetation and topographic features identified during interpretation of satellite and black-and-white aerial photography (Koehler and Carver, 2012) (fig. 53). During limited helicopter reconnaissance across the projections of the lineaments into the Tanana River floodplain and around Chisana Mountain, no geomorphic features that could be attributed to active faulting were observed, implying that the Tetlin Lake lineaments are not active Holocene faults.

\section{Ladue River lineament}

Although Griscom (1976) interpreted a bedrock fault based on aeromagnetic data that display a northeast grain and apparently offset magnetic anomalies, Foster (1970) did not recognize a surface fault along the Ladue River lineament. In the vicinity of the proposed fault, the Ladue River valley is linear, but no scarps, linear troughs, or saddles are present along the fault trace, and broad, gently sloping alluvial-colluvial fans display smooth, unbroken longitudinal profiles (Koehler and Carver, 2012) (fig. 53). This lack of tectonic geomorphic features implies that the Ladue River lineament does not represent an active Holocene fault.

\section{Midway Lake faults}

In her 1970 bedrock geology map of the Tanacross Quadrangle, Foster mapped three short, northwest-trending faults in the southern Yukon-Tanana Upland north of Midway Lake (fig. 53). No surface manifestations of active faulting were observed during DGGS ground and aerial reconnaissances along the fault traces and an investigation of nearby roadcuts (Koehler and Carver, 2012).

\section{Northway Junction faults}

Foster (1970) mapped two northwest-trending faults northwest of Northway Junction in the southern Yukon-Tanana Upland (fig. 53). According to her map, the faults separate biotite gneiss-schist from schist-quartzite metamorphic units and Mesozoic granitic bedrock. Aerial surveys indicate that the faults follow linear vegetation patterns and linear drainages through saddles in bedrock ridges, but lack fresh scarps and other evidence of Holocene tectonic activity (Koehler and Carver, 2012). 


\section{Airs Hills faults}

Richter (1976) mapped two west-northwest-trending fault strands through Paleozoic phyllite, metaconglomerate, greenstone, and quartz-mica schist bedrock in the Airs Hills area in the east-central Nabesna Quadrangle (fig. 53). Both strands are mainly buried beneath alluvium in stream valleys, and the principal evidence for the faults is the bedrock contrasts on opposite sides of the strands. Aerial surveys along both strands failed to identify geomorphic evidence for Holocene faulting, and the faults are considered to be inactive (Koehler and Carver, 2012).

\section{Liquefaction}

On November 3, 2002, the eastern Alaska Range was severely shaken by a M 7.9 earthquake along the DenaliTotschunda fault system, which passes as close as $-56 \mathrm{~km}$ southwest of Northway (fig. 53), and liquefaction effects were widespread (Harp and others, 2003). Clear evidence for earthquake-induced liquefaction was at the Northway Airport, where low sand cones $2-4 \mathrm{~m}$ across with central pits were aligned along the edge of the paved runway (fig. 64). The sand cones were deposited on the ground surface by forceful ejection (fountaining) through subsurface pipes of sand-rich porewaters subjected to elevated pressures in the underlying sandy sediments during the passage of seismic compression pulses through the ground (Walsh and others, 1995). The central pits are the surface ends of the subsurface liquefaction pipes. Future strong earthquakes have the potential to destabilize saturated, liquefaction-prone floodplain sediments and artificial fills in the corridor and to generate slope failures on mountain slopes (Reger and Solie, 2008b; Hubbard and Reger, 2010a; Hubbard and others, 2013).

\section{Permafrost}

Reconnaissance studies of permafrost produced six 1:63,360-scale interpretive permafrost maps that portray the inferred extent and estimated ice content of perennially frozen ground between the ground surface and a depth of $-6 \mathrm{~m}$ (sheets 7-12) (Reger and Solie, 2008a, b; Reger and Hubbard, 2010; Hubbard and Reger, 2010a; Reger and others, 2012b; Hubbard and others, 2013). Average annual air temperatures in the corridor, which favor the formation of perennially frozen ground, range from $-3.3^{\circ} \mathrm{C}$ at Delta Junction in the northwest to $-5.3^{\circ} \mathrm{C}$ at Northway Airport in the southeast, becoming gradually colder southeastward (table 7).
Table 7. Average annual air temperatures at settlements in the Alaska Highway corridor between Delta Junction and the Canada border (https://wrcc.dri.edu/summary/climsmak.html).

\begin{tabular}{|l|c|c|}
\hline \multicolumn{1}{|c|}{$\begin{array}{c}\text { Corridor } \\
\text { settlement }\end{array}$} & $\begin{array}{c}\text { Average } \\
\text { annual air } \\
\text { temperature, }{ }^{\circ} \text { C }\end{array}$ & Years of record \\
\hline Delta Junction & -3.3 & $1966-1969$ \\
\hline Dot Lake & -4.4 & $1905-1975$ \\
\hline Tanacross & -5.1 & $1949-2003$ \\
\hline Tok & -4.7 & $1954-2010$ \\
\hline Northway Airport & -5.3 & $1949-2010$ \\
\hline
\end{tabular}

\section{Definitions}

Permafrost or perennially frozen ground is defined as soil or rock beneath the ground surface that maintains temperatures at or below $0^{\circ} \mathrm{C}$ for $\geq 2 \mathrm{yr}$, regardless of the moisture or ice content, which controls the degree of bonding (Muller, 1947; Ferrians and others, 1969). Permafrost is not necessarily permanently frozen and could be relict, deep masses that developed in past, colder climatic conditions than exist today and are not influenced by changes in modern climate.

The active layer is the zone of seasonally frozen and thawed ground above the top of permafrost, which is called the permafrost table. Complex processes affect the ground during annual freezing and thawing, including changes in moisture states and pore-water conditions, migration of moisture to freezing surfaces, the growth of several forms of ground ice, and intricate displacements of soil particles and masses (French, 2007). During some years, the ground may not freeze as deep as the permafrost table, leaving subsurface thawed zones, called taliks, between the bottom of the seasonal frost and the permafrost. In response to thawing because of climatic changes or movements of groundwater through permafrost, closed taliks (masses of unfrozen ground contained completely within permafrost) may develop in the perennially frozen ground, and thaw bulbs, which are actually closed taliks, exist beneath surface lakes and streams (Péwé, 1982; French, 2007, table 5.4). Open taliks are thawed zones that penetrate through permafrost beneath larger lakes and streams (Lachenbruch, 1968; Ballantyne, 2018, fig. 4.4).

Permafrost is present beneath -85 percent of Alaska (Ferrians, 1965; Jorgenson and others, 2008). The local extent of perennially frozen ground is defined by several 
classes: continuous permafrost underlies $>90$ percent of the landscape; discontinuous permafrost underlies 50-90 percent; sporadic permafrost underlies $10-50$ percent; and permafrost is present as isolated masses where it underlies $<10$ percent of the landscape. A complex of thermokarst processes, which are triggered by climatic warming, wildfires, and other surface disturbances that result in warming of the ground, causes thawing of nearsurface permafrost and affects its distribution (Péwé, 1954, 1982; Ferrians and others, 1969; Osterkamp and Romanovsky, 1999; Osterkamp and others, 2000; Jorgenson and others, 2001; Hinzman and others, 2006; Lipovsky and others, 2006).

Solifluction is the slow downslope frost creep and flow of saturated sediments under the influence of gravity (Andersson, 1906). Gelifluction is downslope displacement by solifluction over frozen ground (Washburn, 1980).

\section{Methods}

We initially inferred the extent of permafrost and ice content by interpreting $\sim$ 1:65,000-scale, false-color infrared aerial photographs taken in July 1978, August 1980, August 1981, and July 1983. Therefore, the units in our permafrost maps illustrate our interpretation of permafrost conditions from July 1978 through July 1983. Proxy data include vegetation, slope and aspect, landforms, geology, local drainage, and terrain features. Landforms such as open-system pingos, lithalses, polygonal ground, thermokarst pits and gullies, and thaw lakes and thaw ponds are diagnostic of the presence or former presence of permafrost (Hopkins and others, 1955; Ferrians and others, 1969; Kreig and Reger, 1982). We also incorporated into our maps the small amount of information available in the professional literature and data from a single temperature-monitoring site in the Scotty Creek lowland (Reger and others, 2012a, b; Hubbard and others, 2013). Subsurface data in the vicinity of Northway were collected by Wallace (1948) and Williams (1970); in the Scotty Creek lowland, borehole data were collected in 1982 and 1992 (Hemenway, 1994). In the field we dug numerous test pits to verify initial interpretations. Our permafrost maps have obvious limitations because permafrost was interpreted using photography taken at least 30 years ago, prior to more recent climatic warming, and several extensive wildfires had altered the surface vegetation across broad swaths of the corridor just prior to the photography upon which our study is based. The magnitude of change in the proposed corridor has not been documented by comparisons with photographs taken before or after 1978-1983. Our permafrost maps should be considered tentative until validated by multi-year ground-temperature measurements at the level of zero annual temperature variation.

Panda and others $(2008,2010)$ used analyses of near-surface $(<1.6 \mathrm{~m}$ depth) ground temperatures collected at 130 sites in the corridor by continuouslyrecording instrumentation during 2008 to develop an 18-km-wide probabilistic map of permafrost straddling the Alaska Highway between AMP 1344 and AMP 1356. Comparison of the map by Panda and others with our photointerpreted permafrost map of the area, which illustrates the inferred extent and ice content of permafrost from the ground surface to a greater depth $(-6 \mathrm{~m})$ based on integrated proxy data (Reger and Hubbard, 2010), indicated 75 percent agreement for continuous permafrost and very close agreement for discontinuous permafrost. Incorporating vegetation and topographic data at 330 locations between AMP 1329 and AMP 1397, Panda and others (2012) modeled the relations between vegetation type, aspect-slope, and permafrost from SPOT 5 satellite data using a Binary Logistic Regression model that predicted the presence of near-surface $(<1.6 \mathrm{~m})$ permafrost to an accuracy of $\sim 88$ percent. Their model predicted that shallow permafrost underlies all (100 percent) of the open spruce forest, 87 percent of the closed spruce forest, and 11 percent of the mixed spruce and deciduous woodland.

After we prepared our initial interpretive permafrost maps, airborne-resistivity data became available in the corridor east of Tetlin Junction (Burns and others, 2006). The data had been collected in 2005 and 2006, using an electromagnetic-emitting transmitter and receiver in an instrument package suspended beneath a helicopter flown $-30 \mathrm{~m}$ above the ground surface (Solie and Burns, 2006, 2007). In the absence of confirming subsurface temperature and borehole data in the corridor, airborne-resistivity data provided the best available, although indirect, measure of subsurface conditions (Reger and others, 2012b) and were recently used to model discontinuous permafrost in the Yukon River lowland (Minsley and others, 2012; Pastick and others, 2013).

For our comparison, we examined 63 northnorthwest-trending, color-formatted 100-m-deep airborne-resistivity sections spaced $0.8 \mathrm{~km}$ apart across the 19-km-wide corridor east of Tetlin Junction (Reger and others, 2012b, p. 3). Different colors in the sections indicate zones of different ground resistivity that were developed using a multilayer inversion model (EM1DFM) (Burns and others, 2006) ${ }^{18}$; using the results, the presence 


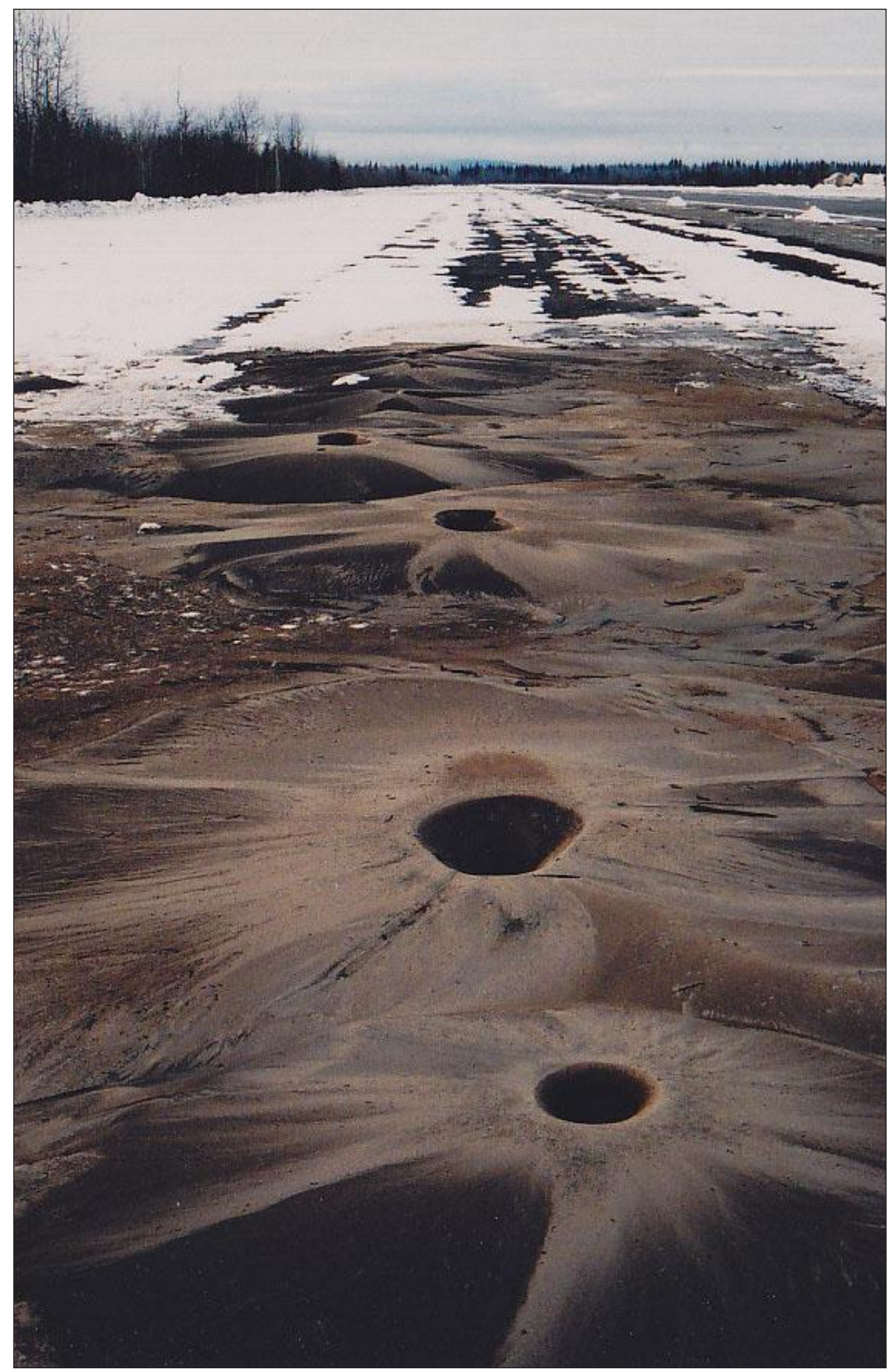

Figure 64. A series of low sand cones with central pits aligned along runway edge at Northway airport, produced by forceful ejection of liquefied sandy sediments beneath the runway margin during the magnitude 7.9 earthquake of November 3, 2002. Photograph taken by Lyle Cronk (https://jukebox.uaf.edu.site7/media-gallery/detail2614/14562). 
of frozen versus unfrozen sediments could be interpreted (fig. 65). On the basis of 11 gravimetric soil-moisture determinations in frozen near-surface eolian and reworked eolian sediments (table 5), we anticipated that colors in the EM1DFM inversion sections also reflect different ground-ice content in fine-grained sediments: dark blue $(2,471-3,705 \mathrm{ohm}-\mathrm{m}$ resistivity) was inferred to indicate moderate to high ice content (50 to $>1,000$ percent gravimetric soil moisture), light blue (1,574$2,471 \mathrm{ohm}-\mathrm{m}$ resistivity) was inferred to indicate low to moderate ice content ( 25 to 50 percent gravimetric soil moisture), light green (951-1,574 ohm-m resistivity) was inferred to indicate low ice content (6 to 25 percent gravimetric soil moisture) (fig. 65A), and yellow-orangered-purple colors (951-235 ohm-m) indicated $<6$ percent ice content or no known permafrost. One measure of the presence or absence of permafrost beneath the seasonally frozen active layer is the depth of ground penetration reached by the electromagnetic energy. Shallow depths are sampled where the sediments are conductive (weakly resistant), such as unfrozen, saturated, fine-grained deposits; greater depths are sampled where near-surface sediments are resistant (weakly conductive), such as perennially frozen, fine-grained deposits with moderate to high ice content (Solie and Burns, 2007). One advantage of the EM1DFM inversion section is that the depths to which the various frequencies penetrated are displayed as lines superimposed over the resistivity colors (fig. 65A). Where permafrost, which has low conductivity, is present, frequency lines are deeper in the EM1DFM inversion section than where permafrost is absent.

Our comparison produced map boundary changes that better reflect local permafrost conditions (sheets 10 through 12). Changes were most pervasive on the floor of the Tanana River valley, where large volumes of groundwater flow through extensive lowland alluvium, and in taliks. Our initial mapping of permafrost in surficial deposits was much more reliable in the southern Yukon-Tanana Upland. Changes in permafrost were generally minor between 1978 and 1981, when the aerial photographs were taken, and 2005-2006, when the electromagnetic survey was conducted. Interpretation of permafrost in bedrock is hampered by the lack of information about bedrock compositions, structures, and conductivities.

\section{Factors affecting the distribution and disturbance of corridor permafrost}

The distribution of perennially frozen ground is a function of present and past climates (Hopkins and others, 1955). As a rough approximation, permafrost forms where the mean annual air temperature at standard instrument height is $<0^{\circ} \mathrm{C}$ (Péwé, 1982). To actually develop perennially frozen ground, the temperature of the ground surface must be $<0^{\circ} \mathrm{C}$ (Muller, 1947; Ferrians and others, 1969). The most accurate relation between permafrost extent and ground temperatures is reflected by ground temperatures measured in permafrost at the shallowest depth where there is no temperature variation (at the level of zero annual amplitude of Péwé, 1982) (fig. 66). Above that level, ground temperatures are affected by seasonal changes in air temperatures, and below that level, ground temperatures gradually increase with depth in response to the geothermal gradient. In general, lowland permafrost is continuous (underlies $>90$ percent of the area) where the ground temperature at the depth of no annual temperature change varies from $-5^{\circ} \mathrm{C}$ to $-11^{\circ} \mathrm{C}$; permafrost is discontinuous (underlies 50-90 percent of the land surface) where steady ground temperatures are $-1^{\circ} \mathrm{C}$ to $-5^{\circ} \mathrm{C}$ at the level of zero annual change; and permafrost is sporadic (underlies 10-50 percent of the area) or is composed of isolated small bodies $(<10$ percent of the area) where unvarying ground temperatures are $0^{\circ} \mathrm{C}$ to $+1^{\circ} \mathrm{C}$ (Ferrians, 1965; Jorgenson and others, 2008). In complex mountain terrains, differences in slope aspect, elevation, and snow characteristics produce highly variable permafrost temperatures.

Local variations in the depth, thickness, ice content, and temperature of permafrost are the result of differences in heat flow into and out of the ground, which are functions of the local geothermal gradient and the interactions of climate and local physiographic and geologic conditions (Williams, 1970). For example, because of low sun angles at the northern latitude of the Alaska Highway corridor, the amount of solar radiation reaching the ground surface significantly affects the amount of heat potentially entering the ground. A $10^{\circ}$ south-facing slope receives -33 percent more solar radiation than a $10^{\circ}$ north-facing slope and $\sim 14$ percent more solar radiation than a flat surface (Hinzman and others, 2006). Although mean annual air temperatures

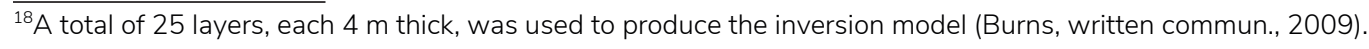


are generally only $-3^{\circ} \mathrm{C}$ colder in valley bottoms and on north-facing slopes compared to south-facing slopes due to convective atmospheric mixing, ground temperatures are significantly colder on north-facing slopes and in valley bottoms because (1) steep winter temperature inversions draw heat out of the ground and (2) significant summer insulation is provided by the widespread surface cover of mosses and lichens. In summer, the moist ground cover dries in the continental climate and insulates permafrost from atmospheric temperature fluctuations, reducing heat flow from the warmer atmosphere into the colder ground. In winter when the ground is frozen, heat flows from the warmer ground into the colder atmosphere. In wet sphagnum moss, this natural heat pump allows 2.5 to 4.5 times more heat flow out of the ground in winter than heat flow into the ground in summer, promoting the formation and preservation of permafrost in these wetland sites (Kreig and Reger, 1982, pl. 5). Thus, topography and aspect significantly influence the distribution of permafrost and surface vegetation, which is a sensitive indicator of ground temperature conditions, especially in the southern Yukon-Tanana Upland.

Near-surface permafrost thaws when ground temperatures rise above $0^{\circ} \mathrm{C}$, as when thermal properties of the ground surface are altered by human activities, geologic processes (such as slope failures), or wildfires, so that heat flow into the ground exceeds winter heat loss. These changes lower the permafrost table and thicken the active layer of seasonal thawing (Ferrians and others, 1969; Jorgenson and Osterkamp, 2005; Lipovsky and others, 2006). Responses to the thawing of perennially frozen ground are functions of the amount and type of ground ice present, the grain size of the frozen materials, and the degree of disturbance. Permafrost contains several forms of ground ice, including buried snow, pond or lake ice, aufeis, glacier ice, pingo-ice lenses, foliated ice wedges, regelation and injection ice masses, thin segregations of clear ice, and pore fillings (French, 2007). Melting of massive ground-ice bodies typically results in considerable differential settlement of the ground surface and the formation of large thaw ponds, thaw lakes, and thaw basins (alas depressions) (Kreig and Reger, 1982). Melting of foliated ice wedges, which form polygonal cells in permafrost (Lachenbruch, 1962), produces rounded surface sediment mounds separated by differentially settled polygonal troughs (Péwé, 1954). Thawing of permafrost that is rich in very thin, segregated ice lenses and thin ice seams produces general lowering of the ground surface without significant differential settling. Thawing of coarse sand and gravel with clear pore-ice fillings and other materials without excess ice accumulation typically results in no thaw-strain settlement. Following wildfires, pre-burn vegetation typically returns in a few years either directly or through a series of successional stages, depending on the type of vegetation formerly present and the severity of the burn (Chapin and others, 2006). If the climate permits, with the return of the surface vegetation, permafrost is generally re-established in sediments thawed as a result of the wildfire.

Although wildfires are generally considered to be the main agent for degradation of near-surface permafrost, the warming climate also exerts profound influences (Jorgenson and Osterkamp, 2005). Temperatures of discontinuous permafrost in central Alaska have increased as much as $1.5^{\circ} \mathrm{C}$ since the mid-1980s (Osterkamp and Romanovsky, 1999). Based on photo interpretation supplemented by numerous field observations, Jorgenson and others (2001) estimated that -42 percent of the permafrost beneath the Tanana River flats south of Fairbanks is at least partially degraded. There, lowland fens are expanding at the expense of low-scrub ${ }^{19}$ lowlands and birch forests growing on slightly higher terrace surfaces. Permafrost degradation there is attributed in part to the flow of groundwater through fens, through taliks in the sporadic to discontinuous permafrost, and through underlying permeable coarse fluvial gravels (Racine and Walters, 1994; Jorgenson and others, 2001; Jorgenson and Racine, 2001). Measurements indicated that groundwater temperatures ranged from $2^{\circ} \mathrm{C}$ to $5^{\circ} \mathrm{C}$. This reservoir of warmth helped thaw the fairly thin and warm $\left(0^{\circ} \mathrm{C}\right.$ to $-3^{\circ} \mathrm{C}$ ) permafrost.

\section{Lowland permafrost}

The extent, thickness, and depth to permafrost are complicated in the lowland complex of morainal, glaciofluvial, eolian, and fluvial deposits in the Alaska Highway corridor.

\section{Moraines and outwash deposits}

Between Delta Junction and the Gerstle River, perennially frozen ground in terminal moraines and associated outwash aprons is generally present as deep, isolated, relict masses with low ice content (Reger and Solie, 2008a) (sheets 7 and 8). According to Williams (1970), perma-

\footnotetext{
${ }^{19}$ Scrublands, which have open to closed canopies of low shrubs dominated by dwarf birch and ericaceous shrubs, include scattered black spruce and larch and are one of the most widespread taiga ecosystems in Alaska (Jorgenson and others, 2001).
} 


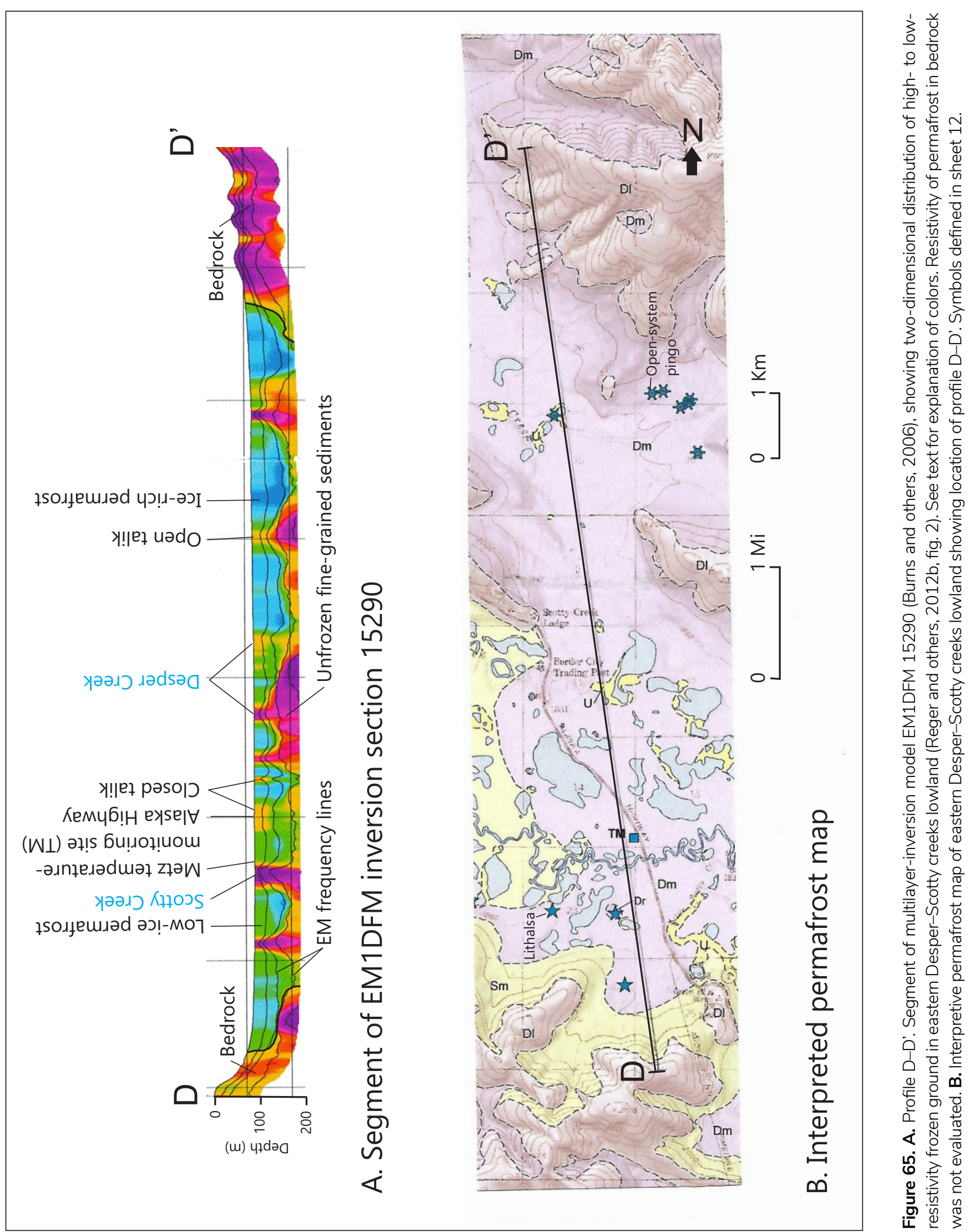


frost at Fort Greely is present in -33 percent of the water wells and is deeper than $66 \mathrm{~m}$, and groundwater distribution there is controlled by subsurface stratigraphy, not permafrost. Surface manifestations of permafrost are generally absent on coarse-grained outwash deposits, except for small thaw ponds in thin, peaty fillings of local basins and in the blanket of frozen loess west of the Delta River. However, small, shallow masses of modern permafrost are reported in coarse alluvium of Donnelly age in the Fort Greely-Delta Junction area (Wilcox, 1980), and trenches along the route of the Trans-Alaska Pipeline System across the late Donnelly outwash fan north of Delta Junction encountered small, active polygonal ice wedges (APSC, 1976; Péwé and Reger, 1983b). In the Fort Greely-Delta Junction area, abandoned channels of Jarvis Creek that cross the Donnelly outwash fan are seasonally flooded be- cause of aufeis formation in the modern channel of Jarvis Creek. Test pits and soil borings indicate that organic silt fillings in some of these paleochannels are discontinuously frozen with scattered, small, isolated crystals of ice. Contraction-crack polygons also form networks on the tread of the post-Donnelly terrace along the west side of the Delta River (Reger and Péwé, 2002).

Terminal moraines of Delta and Donnelly ages associated with the Gerstle and Little Gerstle river lobes are discontinuously frozen with low to moderate ice content (Reger and Solie, 2008a) (sheets 1, 2, 7, and 8). In general, Delta moraines have more and larger kettle fillings of slopewash sediments, lowland loess, and peat, which likely contain thin, ice-rich masses of permafrost. Outwash of Donnelly age is discontinuously frozen with low to moderate ice content, depending on the surface cover of lowland silt and the vegetation cover. Williams

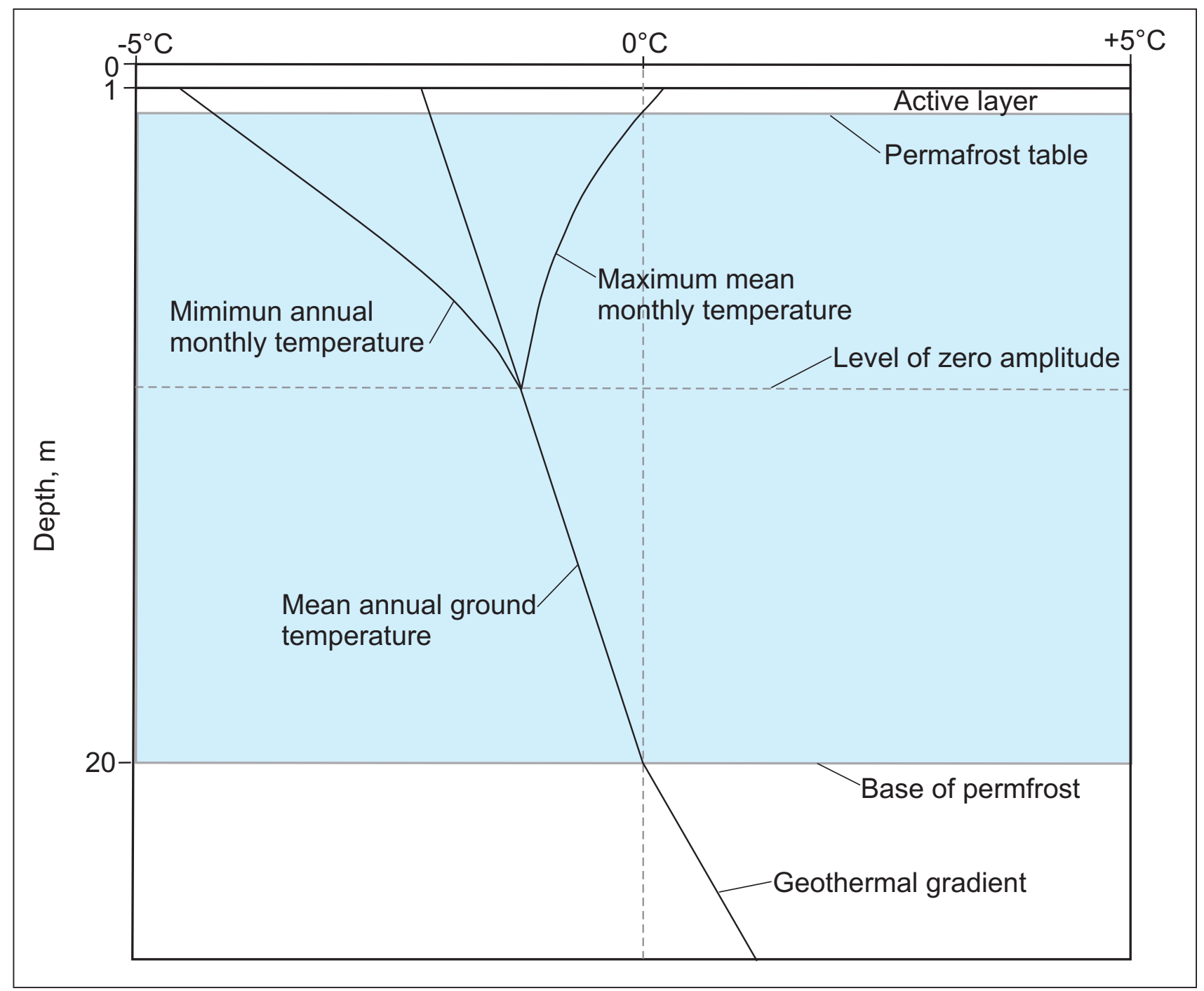

Figure 66. Generalized ground-temperature profile in area of permafrost (after Péwé, 1982, fig. 20). 
(1970, p. 43-44) documented permafrost in a water well in Donnelly outwash near the Gerstle River (Reger and Solie, 2008a) (sheets 1 and 7, locality B). The well penetrated $37 \mathrm{~m}$ of permafrost from the ground surface down through $24 \mathrm{~m}$ of surface outwash gravel and 13 $\mathrm{m}$ of underlying sand and till. Because the well yield was inadequate, the well was deepened to $167 \mathrm{~m}$, and eventually adequate water was obtained from a layer of sand and gravel between depths of 143 and $144 \mathrm{~m}$. The water table subsequently stabilized $102 \mathrm{~m}$ below the base of the permafrost, indicating that subsurface stratigraphy, not permafrost, controls the distribution of groundwater there. Permafrost was not encountered in the 42-m-deep water well drilled for the Dry Creek community in proximal outwash deposits near the Johnson River (Reger and Solie, 2008a) (sheets 2 and 8, locality A).

Morainal and outwash deposits in the Robertson River area are apparently discontinuously frozen with low to moderate ice content (Reger and Hubbard, 2010) (sheets 2, 3, 8, and 9). North of the Robertson River, the deciduous tree cover indicates that the higher, outer zone of the Donnelly terminal moraine is discontinuously frozen with low ice content. A single, moderate-sized ice wedge of probable late Donnelly age was observed in loess-covered till of Donnelly age $7.4 \mathrm{~km}$ west of the Alaska Highway along the southern margin of the Robertson River floodplain in the northwestern Tanacross B-6 Quadrangle. Widespread spruce and the relatively low relief of the loess-blanketed, inner Donnelly terminal moraine indicate that permafrost is discontinuous with low to moderate ice content. Lowland loess and peat in local basins and drainages are continuously frozen and ice rich. Taliks exist beneath larger lakes.

Coalescing outwash fans of Delta and Donnelly ages form a discontinuously frozen apron with low to moderate ice content along the lower slopes of the eastern Alaska Range between the Robertson River and the range front southwest of Tanacross airfield in the Tanacross B-5 and B-6 quadrangles (Reger and Hubbard, 2010). However, fine-grained, distal fan sediments along the toe of the apron west of the Tok fan appear to be continuously frozen and ice rich (sheets 3, 4, 9, and 10).

\section{Eolian deposits}

In unburned areas on the thick loess blanket west of the Delta River, permafrost is sporadic with low ice content, based on known permafrost conditions in equivalent landforms east of the Delta River (sheets 1 and 7). Organic silt and sand fillings of thaw basins and small thaw ponds are likely frozen with moderate to high ice content. Numerous thaw ponds in sandy eolian silt on the broad coalescent outwash fans of Delta and Donnelly ages east of the Delta River indicate that near-surface permafrost is thin and discontinuous with low to moderate ice content. Based on numerous borings in sand dunes in the Shaw Creek area (Kreig and Reger, 1982, pl. 9), mappable sand dune complexes on outwash fans between Delta Junction and the Gerstle River are generally unfrozen or probably have low to very low ice content.

The Donnelly terminal moraine at Johnson River has an extensive and fairly thick cover of eolian sand and silt deposited by strong katabatic winds blowing across the nearby braided floodplain (Reger and others, 2008a). The deciduous and mixed deciduous-coniferous forests on high-relief esker-kame deposits, till, and sand dunes indicate that permafrost is discontinuous with low ice content (sheets 2 and 8). Widespread coniferous woodland, primarily black spruce, on surfaces of low relief indicates the presence of discontinuous permafrost with generally low to moderate ice content. Continuous permafrost with high ice content is probably present in peaty kettle fillings and in local drainage systems with sedge-shrub vegetation.

The Tetlin Junction dune field likely has discontinuous permafrost with low ice content, except where the dune sands have been retransported downslope. There, discontinuous permafrost has moderate to high ice content (Reger and Hubbard, 2010) (sheets 4 and 10). In the Alaska Highway corridor southeast of Tetlin Junction, the belt of sand dunes is discontinuously frozen with low to moderate ice content (Reger and others, 2012b; Hubbard and others, 2013).

EM1DFM inversion sections indicate that permafrost in the Gardiner Creek dune field is discontinuous, has a maximum thickness $>100 \mathrm{~m}$, and ice content ranges from low to high (Reger and others, 2012b; Hubbard and others, 2013) (table 4). A riparian gallery of tall spruce trees and large willow shrubs on low terraces adjacent to lower Gardiner Creek signifies the presence of a 290- to 400-mwide thaw bulb (talik) along the stream. Examination of EM1DFM inversion sections 14830 and 14840 (Burns and others, 2006) reveals that the thaw bulb (open talik) penetrates through the thick permafrost. Several degraded open-system pingos are identified among the extensive frozen sand dunes in the Gardiner Creek lowland (sheets 6 and 12). Many pingos are related to former local drainages now filled with fine-grained, organic, retransported eolian sediments with lowland loess, which are mapped as discontinuously frozen with moderate to high ice content (Reger and others, 2012b). Differentiating pingos from small sand dunes is not practical using aerial photographs, and some open-system pingos probably are misidentified 
or unidentified. Similarly, some features identified as thaw lakes in the lowland could be the remains of degraded open-system pingos.

At AMP 1240.3 the Alaska Department of Transportation and Public Facilities conducted an innovative experiment using a buried open-duct structure to chill and stabilize the thick highway fill crossing ice-rich retransported loess and eolian sand (Braley and others, 1991; Reger and others, 2012b, p. 17-19) (sheet 12).

\section{Floodplain and terrace deposits}

Understanding the plant succession on the Tanana River floodplains and its relation to developing permafrost is fundamental to our mapping of permafrost in the floodplain and terraces, a process based to a large degree on the character of the surface vegetation. Although the general succession has been known for many years (Viereck, 1970; Kreig and Reger, 1982), the significance of black spruce in the series remains uncertain (Mann and others, 1995). The succession begins with the emergence of bare channel bars and meander scrolls on the inner sides of meanders. Scattered willows and horsetails opportunistically colonize the raw mineral soils, which freeze and thaw annually. Within -5 years, horsetail meadows and open willow thickets develop on the inactive floodplain. These communities can accommodate periodic inundation and sediment accumulation by growing adventitious roots (Chapin and others, 2006). Then alders and balsam poplars invade older floodplain surfaces, the former adding important nitrogen to the soil through the action of nitrogen-fixing bacteria on their roots. In this phase, permafrost is sporadic and has low ice content. During the next -50 years, fast-growing poplars tower above and replace the willows, which are not shade tolerant, forming poplar groves of generally uniform ages, and allowing permafrost to spread and thicken. On older, higher surfaces of the inactive floodplain, white spruce, which has shade-tolerant seedlings that are unable to tolerate frequent burial and do not survive frequent flooding on younger surfaces, is able to survive. Spruce is slower growing than poplars but lives longer, so gradually the spruce mixes with the poplars and replaces them. During this shady phase, when the surface cover of mosses and lichens thickens enough to insulate the ground, permafrost becomes discontinuous and develops low to moderate ice content. Gradually, forests of mixed white and black spruce develop on the abandoned floodplain, especially on natural levees and crevasse splays, which stand above the surrounding land surface and are better drained. These mixed conifer forests may persist for several millennia (Mann and others, 1995). In lowlands behind natural levees and crevasse splays on the abandoned floodplain, occasional flooding produces moist to wet soil conditions in which black spruce and eastern larch dominate (Viereck, 1970), and peat accumulates, promoting the development of continuous, ice-rich permafrost.

Changes in the form of shallow lakes that develop in swales between low scroll ridges on the point bars of meandering streams document four successive phases in the development of permafrost (fig. 67). These phases are distinguished by differences in lake shapes, vegetation, orientation of lakes relative to the modern channel, character of the former stream bank, the distribution of driftwood, and the frequency of flooding (Péwé, 1975a, p. 68). Perennially frozen ground is absent in the linear phase of the inactive floodplain, but in the advanced linear phase, discontinuous masses begin forming on older, higher surfaces of the inactive floodplain (fig. 68). As permafrost spreads and thickens beneath the abandoned floodplain and low terraces, point-bar lakes expand and coalesce through the thawing of ice-rich frozen ground around their margins and, in the coalescent and scalloped phases, permafrost becomes discontinuous to continuous, shallow, and ice rich.

Floodplain and low terrace deposits in the corridor consist of gravel and sand in reaches with braided channels and are composed of sand with beds and lenses of silt and gravel where channels are meandering and anastomosing (Reger and others, 2008a, 2011, 2012a). The meandering-anastomosing channels of the Tanana River and the active braided floodplains with numerous unvegetated bars of its major meltwater tributaries are generally unfrozen, and permafrost does not develop until these surfaces become stabilized and plants become established (Viereck, 1970; Kreig and Reger, 1982). Large floodplain islands that support mature stands of white and black spruce have discontinuous permafrost with low to moderate ice content (Mann and others, 1995; Kreig and Reger, 1982). The frequency of wildfires is generally low on larger islands, so the largest and oldest spruce trees grow there. By analogy, post-Donnelly terraces along the Tanana River with extensive stands of mature white and black spruce also contain discontinuous permafrost with low to moderate ice content.

Near the western end of the corridor, permafrost is absent beneath Clearwater Lake and Clearwater Creek, which exist because high-volume, perennial springs emerge along the base of the nearby Clearwater Lake escarpment (Wilcox, 1980). The abandoned floodplain in the vicinity of Clearwater Lake is vegetated with dense wil- 
low thickets and scattered black spruce and eastern larch, indicating that permafrost is discontinuous with low to moderate ice content (sheets 1 and 7). Concentrations of small thaw ponds are signs that perennially frozen ground is locally shallow and ice rich. Better-drained natural levees and crevasse splays support stands of robust white and black spruce, indicating discontinuous permafrost with low to moderate ice content. On interchannel islands on

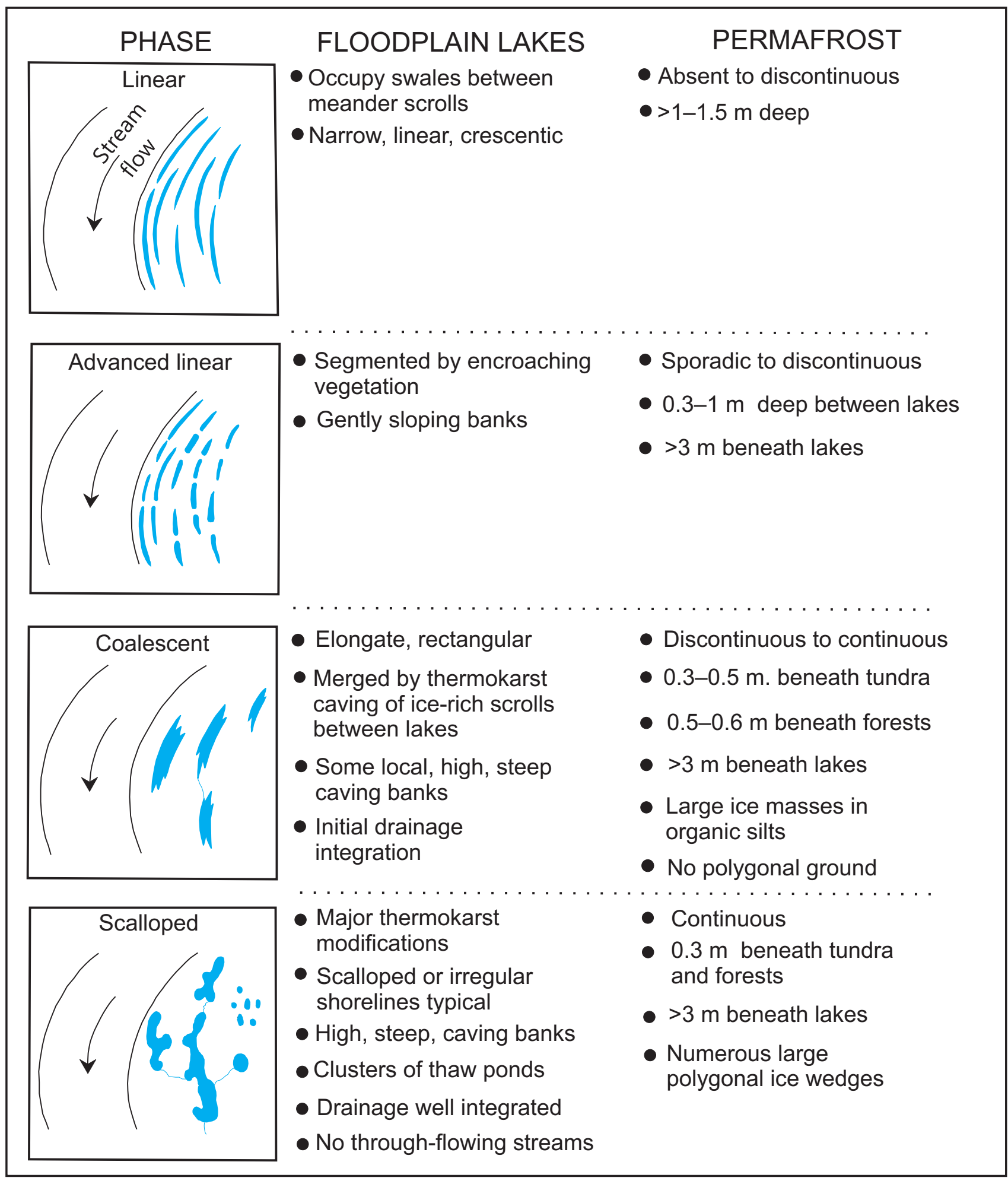

Figure 67. Evolution of shallow lakes on floodplains of meandering streams by thermokarst activity in a permafrost environment (Weber and Péwé, 1961, 1970; and Péwé, 1970). 
the distal Holocene fan of lower Sawmill Creek along the southern margin of the abandoned Tanana River floodplain, moist soils support dense stands of black spruce and eastern larch and dense willow thickets, indicating that permafrost is discontinuous with low to moderate ice content (Viereck and Little, 1972). However, the network of small, braided-to-anastomosing, peat-filled channels is likely to be generally unfrozen because surface drainage is directly connected with shallow groundwater. These conditions are unusual for the abandoned floodplain of the Tanana River, where perennially frozen ground is usually shallow, continuous, and ice rich (Kreig and Reger, 1982; Mann and others, 1995), and could be related to an influx of relatively warm runoff from Sawmill and Rhoads creeks (Reger and Solie, 2008a).

In the vicinity of Johnson Slough and in the broad wetland north of Dot Lake Village, the Tanana River has an anastomosing-meandering pattern that is mimicked by former channels and by floodplain lakes on inactive and abandoned floodplains and on low terraces (Reger and others, 2008a). The extent of permafrost and its ice content in the Dot Lake lowland are questionable because of the abundance of water there, which has promoted the widespread growth of peat (paludification). This wetland is probably a zone of groundwater emergence, which would introduce considerable heat into the environment and limit permafrost development. We suggest that permafrost there is sporadic with low to moderate ice content.

A mixed deciduous-coniferous forest on the large Holocene expansion fan southwest of Wolf Lake in the northeastern Tanacross B-5 Quadrangle indicates that permafrost is discontinuous with low to moderate ice content (sheets 4 and 10). The expansion fan separates the meander belt of the Tanana River from a narrow, swampy slackwater basin against bedrock of the southern Yukon-Tanana Upland. Shrubby vegetation and wet surface conditions in the slackwater lowland are evidence that surface drainage is widely restricted by continuous permafrost.

Interpretations of aerial photographs imply that frozen overbank deposits in the proximal part of the Tok River alluvial fan have low to moderate ice content. Peat-filled channels on the fan are frozen with moderate to high ice content. Concentrations of shrubby vegetation, thaw ponds, and thaw lakes on the fan surface are evidence that shallow permafrost has high ice content. Thaw bulbs with low to moderate moisture content are present in granular channel deposits beneath active and former channels of the Tok River. In the distal half of the Tok River alluvial fan and beneath the floodplain of the nearby Tanana River, fine-grained sediments are generally unfrozen to discontinuously frozen with low to moderate ice content. East of the Tok River meander belt, sedge and willow lowlands and channels are interpreted as a zone of groundwater emergence (sheet 4), and permafrost is inferred to be sporadic with low to moderate ice content (sheet 10). An extensive zone of groundwater emergence in the northcentral distal Tok River alluvial fan is indicated by (1) numerous clearwater springs and channels, (2) a network of anastomosing, natural drainage channels with watertolerant shrubs and peat, and (3) several clearwater lakes (sheets 4 and 10). In this area, permafrost is inferred to be sporadic with low to moderate ice content.

Southeast of the Tok River alluvial fan, permafrost is mapped as discontinuous with low to moderate ice content on older terraces and abandoned floodplains with extensive scrublands (sheets 4, 5, 10, and 11). Widespread sporadic permafrost is present in sediments on inactive and abandoned floodplains along active channels and in scrublands on low fluvial terraces, where surface water bodies are numerous, scattered, small, and shallow (Reger and others, 2012a). According to Wallace (1948, p. 174), the permafrost table is $\sim 0.3$ to $0.6 \mathrm{~m}$ deep beneath the moss-covered forest floor between thaw lakes. Groundwater in $>75 \mathrm{~m}$ of alluvium at Northway Airport is confined beneath permafrost as thick as $-27 \mathrm{~m}$, and several $15 \mathrm{~m}$ borings in the Nabesna River floodplain near Northway punched through permafrost. Perennially frozen ground is discontinuous beneath long-abandoned silt- and peat-filled stream channels. However, examination of EM1DFM inversion sections indicates that permafrost is absent beneath active stream channels and lakes and sporadic beneath recently abandoned, silt-filled channels. Peats are unfrozen in these channels and around the margins of the larger lowland lakes, but are frozen and ice rich in smaller, isolated thaw basins and lowlands. Smaller thaw lakes typically occupy shallow, closed taliks underlain by permafrost.

Numerous thaw lakes are present on fine-grained, perennially frozen fluvial terraces in the Northway lowland. Those lakes typically exhibit circular to complex, locally scalloped shorelines, are 1.5 to $3 \mathrm{~m}$ deep, and have fairly flat bottoms (Wallace, 1948) (sheets 5, 6, 11, and 12). Along actively retreating steep banks, trees are characteristically tilted toward the lakes. Counts of growth rings in 15 tilted spruce trees indicate that banks recede 6 to 


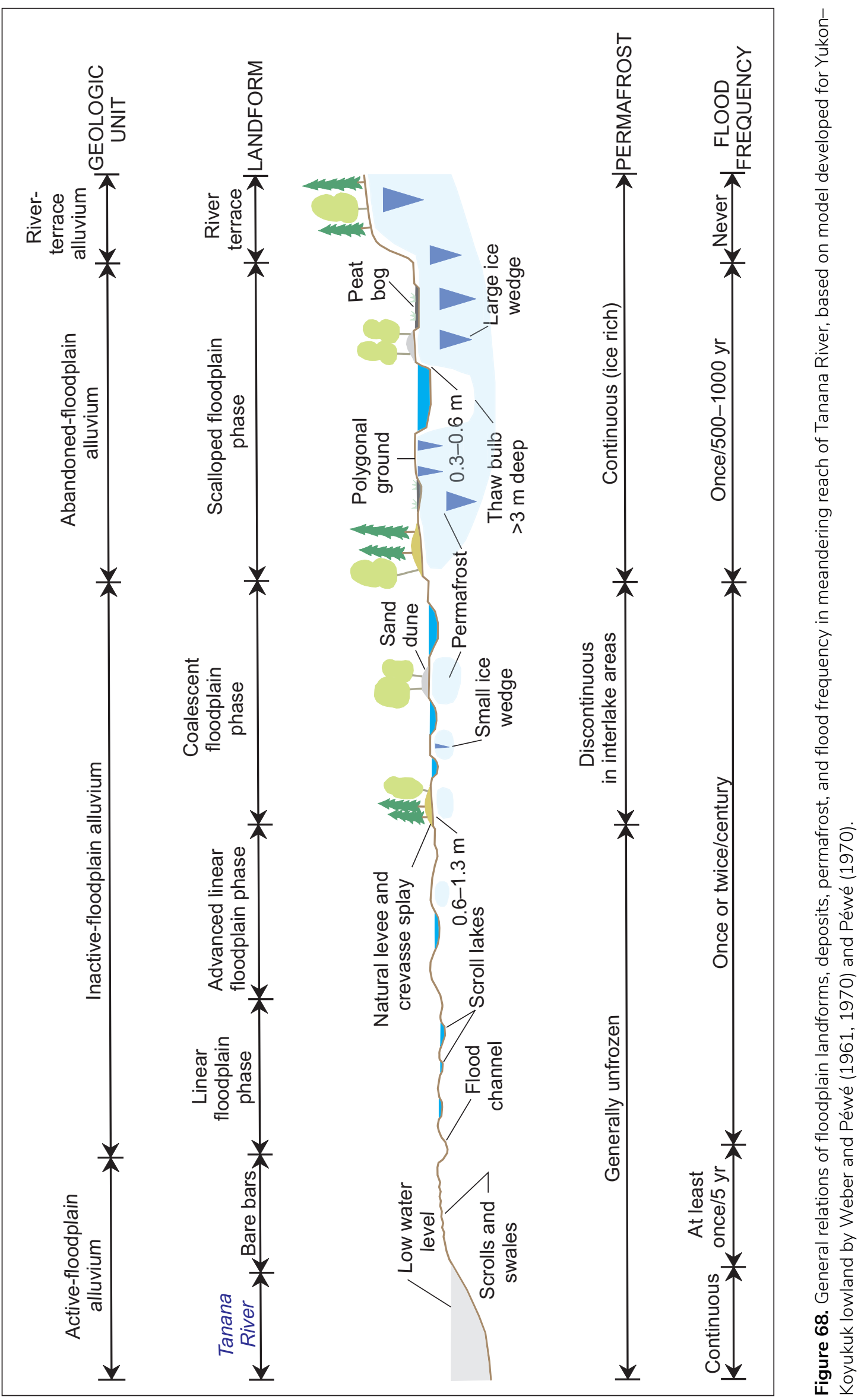


$19 \mathrm{~cm} / \mathrm{yr}$ (Wallace, 1948, p. 179). Spruce trees with roots that subside beneath lake waters due to bank recession die after 10 to 15 years of root submergence. Where vegetation mats drooping down steep banks rip and expose the underlying ice-rich permafrost, accelerated thawing locally produces mudflows and scalloped shorelines (fig. 69). Airborne resistivity sections (Burns and others, 2006) support the conclusion by Wallace (1948, p. 174) that permafrost is deeper than $3 \mathrm{~m}$ or does not exist beneath thaw lakes in the Northway lowland.

Wallace (1948) proposed a model for the evolution of thaw lakes in the Nabesna-Chisana rivers lowland that is initiated when a break in the vegetation mat, perhaps as a result of wildfire (Burn and Smith, 1990), exposes underlying ice-rich permafrost, and a small, generally circular thaw basin soon forms where surface water accumulates. Solar radiation warms this water, which has a fairly high specific heat (defined as calories of heat required to raise the temperature of $1 \mathrm{gm}$ of water $1^{\circ} \mathrm{C}$ ) (Merriam-Webster, 2002), and secondarily thaws the surrounding frozen ground. Expanding thaw basins develop into thaw ponds and eventually into thaw lakes (fig. 70A). In the process, expanding thaw lakes inevitably intersect and combine to form compound basins with scalloped shorelines inherited from initial circular shapes (fig. 70B). Scalloped shorelines also result from faster local thawing in ice-rich permafrost than in adjacent deposits with less ground ice. Through time, older groups of expanding thaw lakes combine to form extensive complexes, lake outlines become very irregular, and lakes commonly intersect channels (fig. 70C). During high stream stages, turbid floodwaters enter thaw-lake basins near active streams and initially deposit simple lake deltas that grow into complex forms by the extension and confinement of stream channels between natural levees. Complexes of levee-bound meandering stream channels eventually segment the lake basins into subbasins (fig. 70D).

We recognize the circular lake and early coalescent phases of Wallace's thaw-lake cycle on fluvial terraces isolated from active streams in the Northway lowland and accept Wallace's explanation for their origin (figs. 70A and B). Study of EM1DFM inversion sections indicates that taliks are -25 to $60 \mathrm{~m}$ deep beneath those water bodies. However, we suggest a slightly different interpretation of Wallace's integrated-drainage and segmented-basin phases (figs. 70C and D), which we note are invariably located close to active or former meandering stream channels. Because fluvial terraces, by definition, are not subject to seasonal flooding, thaw lakes on higher terraces distant from active or formerly active streams cannot develop flood-related deltas and integrated drainages. In our model, large and complex lake basins (figs. 70C and D) evolve by thermokarst modification of ice-rich bank sediments of lakes in slackwater basins associated with meandering streams and do not necessarily originate as local thaw basins and ponds. Actively caving, scalloped lake banks and tilted shoreline trees demonstrate that lakes in slackwater basins are modified by thermoerosion of ice-rich permafrost; remnants of former natural levee-lake delta complexes demonstrate that these features are fine grained and are also subject to thermokarst degradation (fig. 71). Thus meandering, levee-confined channels and complex lake deltas that fill and segment slackwater-basin lakes are natural consequences of long-term river flooding and are not necessarily related only to thaw-lake development.

Scattered thaw-lake basins drain suddenly when headward-eroding tributaries intersect their margins, initially exposing fine-grained lake-bottom sediments. Depending on the topography of the former lake basins, subsequent basin deposits can include complexes of pond or lake sediments in depressions, mass-movement deposits near steep former lake margins, peat that develops on higher ground, and eolian sediments (Murton, 1996). Permafrost soon becomes re-established in former lake basins, where local relief develops due to the growth of ground ice in the aggrading permafrost. Because of slumping of older bank sediments into thaw lakes and their subsequent redistribution throughout the basin by waves and currents, radiocarbon ages of thaw-lake deposits are generally considered to be unreliable (Hopkins and Kidd, 1988; Nelson and others, 1988; Abbott and Stafford, 1996).

\section{Jökulhlaup deposits}

Based on vegetation covers and comparisons with analogous terraces near Fairbanks (Péwé and others, 1966), gravel and sand expansion fans deposited by massive outburst floods in the upper Tanana River drainage likely contain sporadic and discontinuous permafrost with low ice content (sheets 2-4 and 8-10). Logs of 16 water wells in the Tok expansion fan demonstrate that permafrost was present in 25 percent of the wells, suggesting that permafrost is sporadic with low ice content (Williams, 1970). During September 1974, however, 17 soil borings drilled to a depth of $16.7 \mathrm{~m}$ in an -880 by $\sim 1,300 \mathrm{~m}$ area near Tok all encountered permafrost in sandy gravel at depths of 0.6 to $4.6 \mathrm{~m}$, indicating that, at least locally, perennially frozen ground is continuous (Kreig and Reger, 1982, pl. 7). Because the near-surface 
part of the extensive Tok expansion fan was deposited during the last major (Donnelly) glaciation, the permafrost in these deposits must be late Donnelly to Holocene in age (Reger and Hubbard, 2010). Deeper bodies of permafrost in the fan are probably relict and do not reflect the modern climate.

Shrubby and sedge-dominated surface vegetation and the presence of numerous open-system pingos and thermokarst features indicate that fine-grained deposits and peat in slackwater basins behind late Pleistocene expansion fans are discontinuously to continuously frozen with moderate to high ice content (Reger and others, 2008a). Although lakes and large ponds dammed by the expansion fans in re-entrants along the southern margin of the Yukon-Tanana Upland are generally not underlain by permafrost, fine-grained deltas built into Black Lake and Sand Lake by Holocene flooding probably contain sporadic permafrost. The presence of numerous thaw ponds in the Sand Creek delta in Sand Lake indicates the delta is very unstable, thawing, and disintegrating (fig. 72).
In 33 test borings made during April 1987 in the gravel-rich longitudinal flood bar near upper Sam Creek (Material Site 62-2-066-2 and extension), Brazo (1988) observed frozen ground below the probable depth of annual freezing $(2.4 \mathrm{~m})$ in half of the borings, and permafrost was $>9 \mathrm{~m}$ thick in one boring (sheets 2 and 8 ).

Osterkamp and others (2000) documented the replacement of spruce forests by wet sedge meadows, bogs, and thermokarst ponds and lakes in response to the thawing of ice-rich, discontinuous permafrost at five sites in the Mentasta Pass area along the route of massive outburst floods of Donnelly age. Three of their sites were in the Station Creek valley near Mineral Lake and two were in the Slana Slough lowland in the middle Slana River drainage. Silt mounds up to $-3 \mathrm{~m}$ high in the area were considered to be the result of the incorporation of ice-rich active layers by upward-aggrading (syngenetic) permafrost and are being reduced by thermokarst processes attacking the marginal slopes.

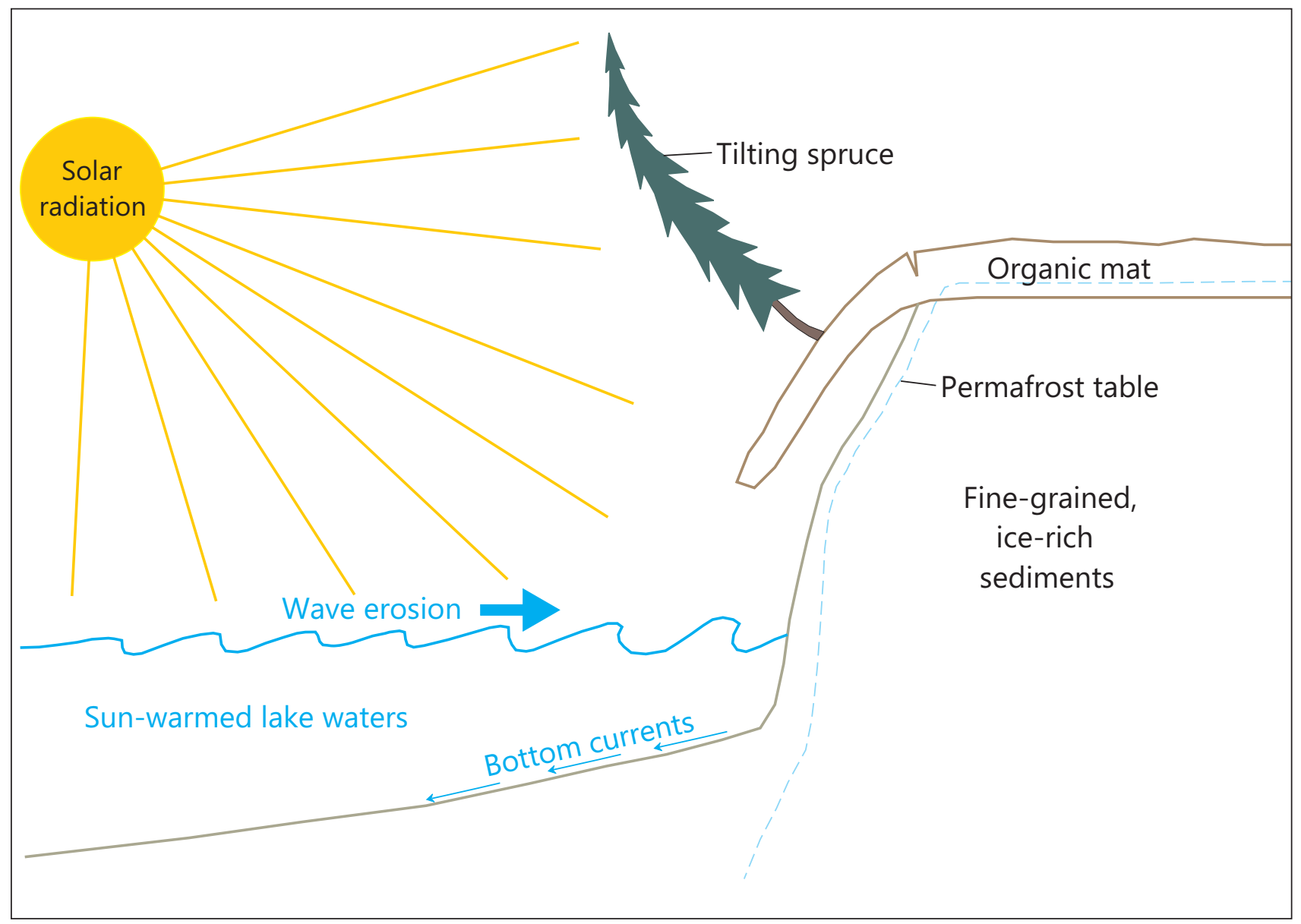

Figure 69. Factors influencing expansion of thaw lakes through bank recession (Reger and others, 2012b, fig. 4). 


\section{Upland permafrost north of the Tanana Lowland}

The presence of permafrost in surficial deposits beneath lower slopes and lowlands in the southern Yukon-Tanana Upland is demonstrated by numerous open-system pingos, thaw ponds and thaw lakes, and debris flows that are a consequence of widespread recent wildfires. A survey of EM1DFM inversion sections across the southern upland indicates that permafrost is generally continuous with moderate to high ice content in thick valley fills, and perennially frozen ground is apparently discontinuous with low to moderate ice content in thin fills in upper drainages, although we have not evaluated possible influences of the resistivity of near-surface bedrock on electromagnetic responses where unconsolidated surficial deposits are thin. Many small tributary drainages head in thaw ponds and thaw lakes, peat bogs, and open-system pingos, hinting of groundwater access in local areas of sporadic permafrost. Surface vegetation in wetlands underlain by shallow continuous permafrost consists primarily of sedge tussocks, low willow and resin-birch shrubs, and scattered stunted black spruce (fig. 73). Infiltration of precipitation waters is restricted by the impermeable shallow permafrost, ponding shallow surface water between sedge tussocks and locally around stunted black spruce. In these areas, ground ice is present as small segregations, polygonal ice wedges, and pingo ice. Although there is a general lack of thermokarst features in the thick, featureless blanket of undifferentiated eolian deposits in local basins in the southern Yukon-Tanana Upland, study of EM1DFM inversion sections indicates that perennially frozen ground is discontinuous with low to moderate ice content.

\section{A. Circular-lake phase}

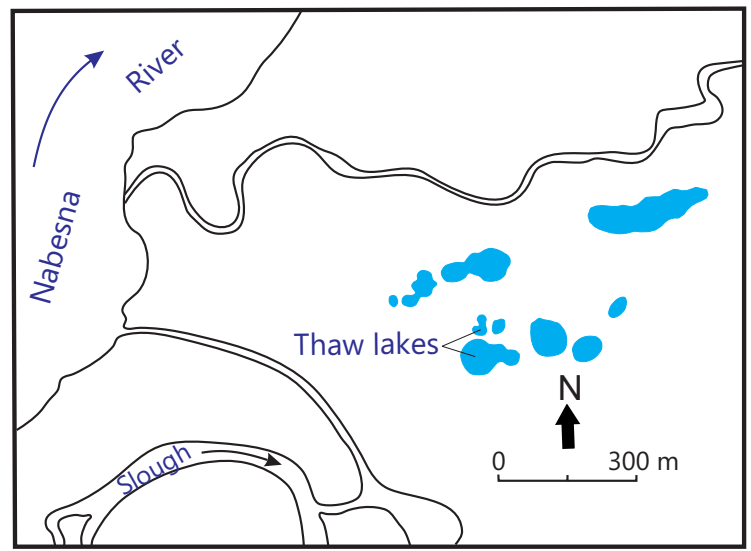

\section{Integrated-drainage phase}

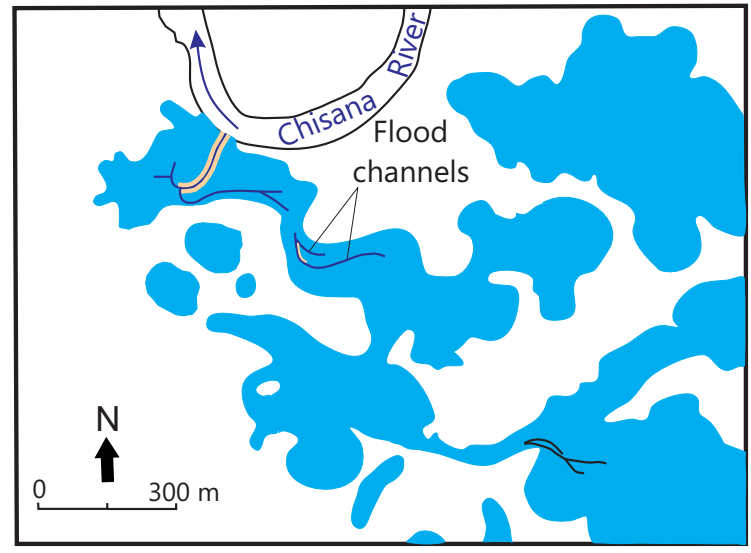

B. Early coalescent phase

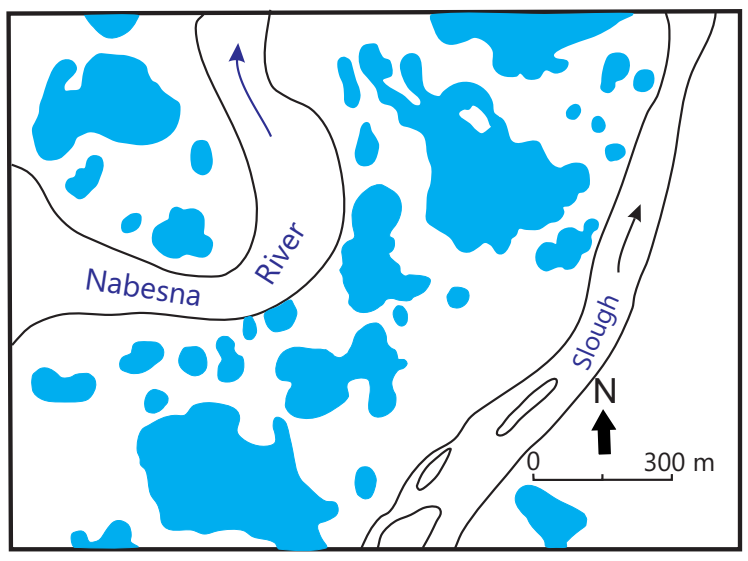

D. Segmented-lake phase

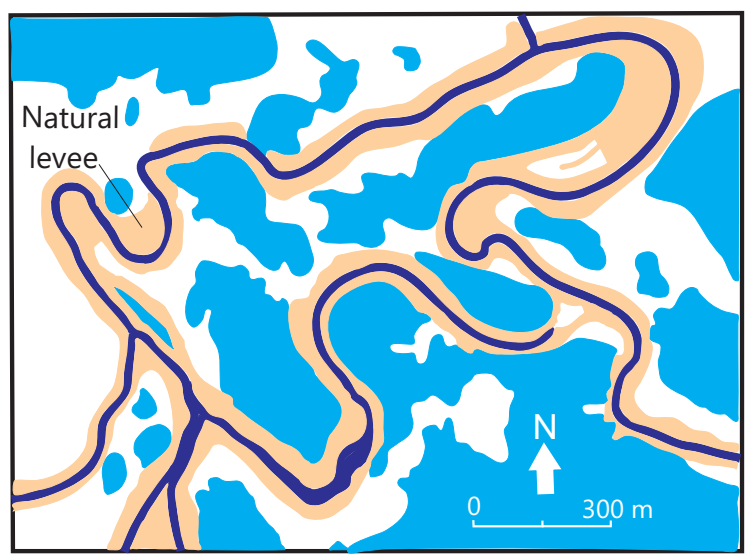

Figure 70. Evolution of thaw lakes in Nabesna-Chisana rivers area, Northway lowland, according to Wallace (1948, figs. 4-7). 
In contrast to the broad morainal belts and outwash aprons in the lowlands of the Tanana River valley, where permafrost map units are typically large, permafrost in the southern Yukon-Tanana Upland is complexly distributed because of local differences in topographic relief and aspect (Reger and Solie, 2008a; Reger and Hubbard, 2010; Reger and others, 2012b). Relatively warm, south-facing bedrock bluffs along the Tanana River receive more solar

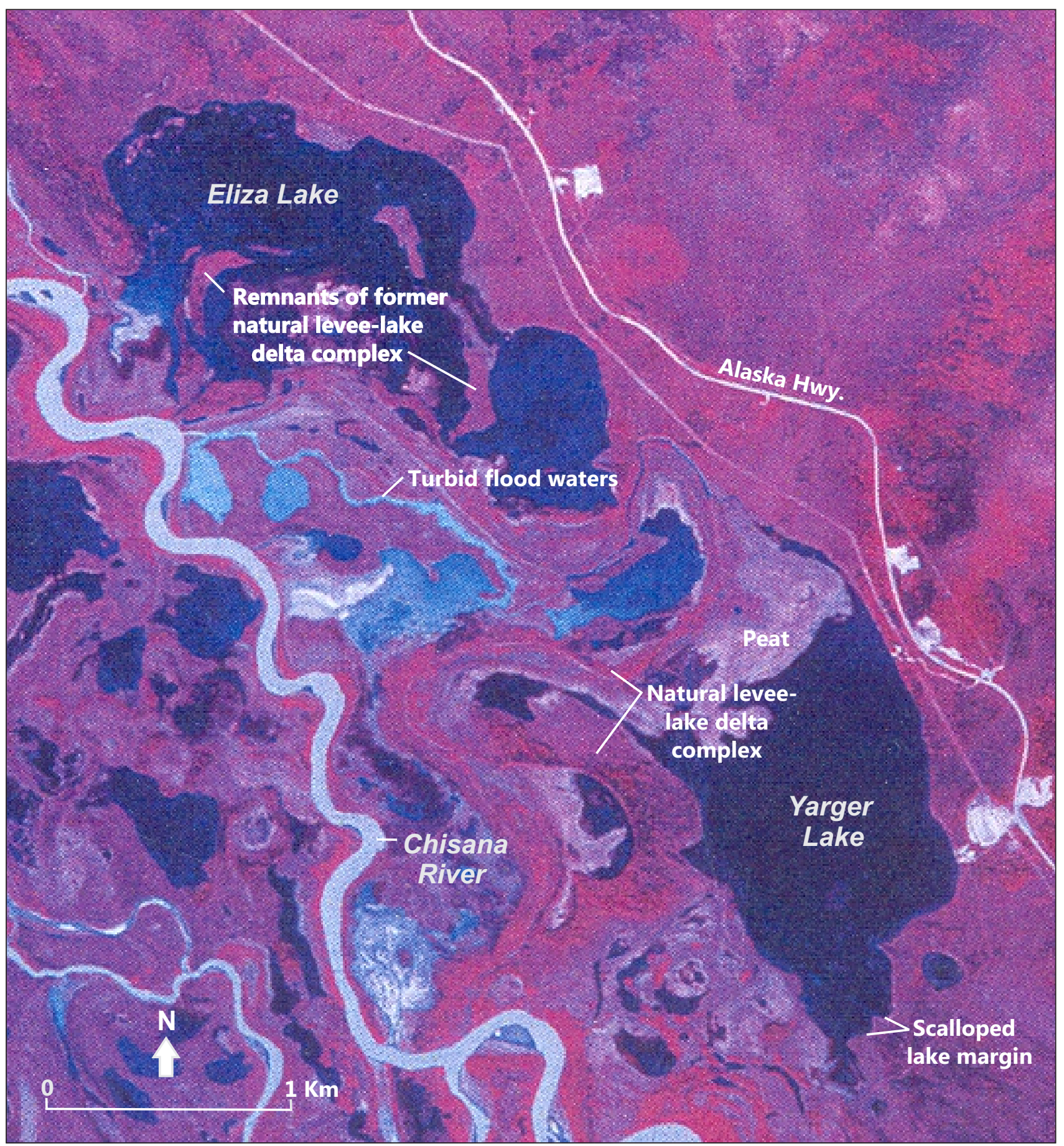

Figure 71. Vertical false-color infrared aerial photograph showing natural levee-lake delta complexes that intricately divide former large slackwater lake basin into numerous subbasins, including Eliza and Yarger lakes, northeastern Nabesna D-2 Quadrangle (Alaska High Altitude Photograph ALK 60 CIR 21-408, taken July 1978) (Reger and others, 2012b, fig. 6). Note contrast between turbid river waters and clear lake waters. Scalloped shorelines and remnants of former natural levee-lake delta systems are evidence of thermokarst degradation. 
radiation than other slopes and are generally unfrozen. Those slopes, which tend to be droughty, support a steppelike vegetation dominated by herbs, shrubs, and scattered aspen and white spruce trees that tolerate aridity (Chapin and others, 2006). Sporadic permafrost with low ice content on lower south-facing slopes is indicated by the forest of deciduous and mixed deciduous-coniferous trees. Ridge crests and upper eastern and western slopes that are covered with deciduous trees are typically discontinuously frozen with low ice content. Numerous small areas along ridges in the southern Yukon-Tanana Upland have a history of frequent burning when summer lightning ignites wildfires. These parklands have few trees and are occupied by grasslands with scattered shrubs (Kreig and Reger, 1982, pl. 11). In these burn areas, permafrost is mapped as questionably discontinuous with low to moderate ice

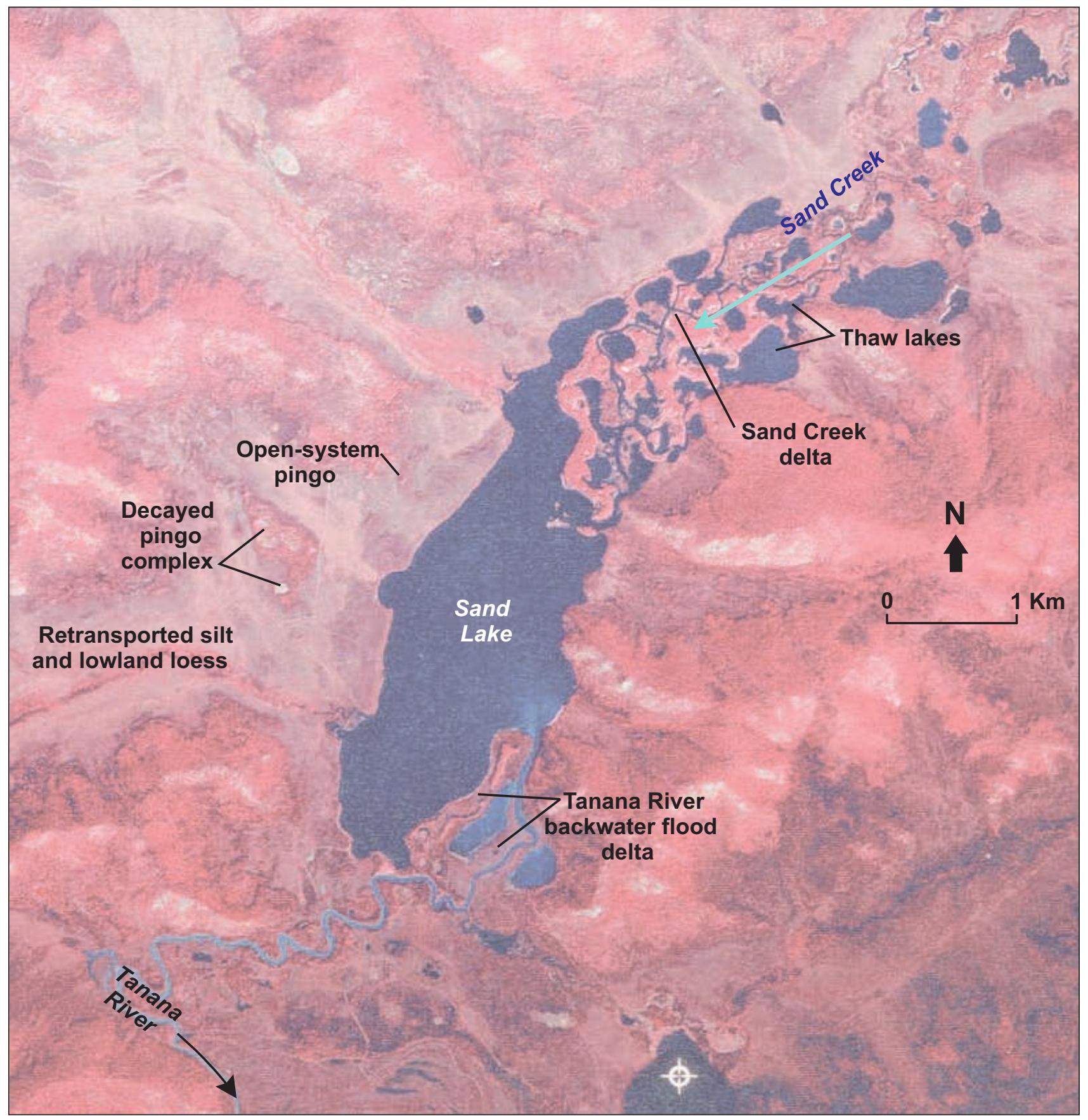

Figure 72. Vertical false-color infrared aerial photograph showing permafrost-related landforms in Sand Lake area, northcentral Mount Hayes C-1 Quadrangle (Alaska High Altitude Photograph ALK 60 CIR 8624, taken August 1980) (Reger and Solie, 2008a, fig. 2). 


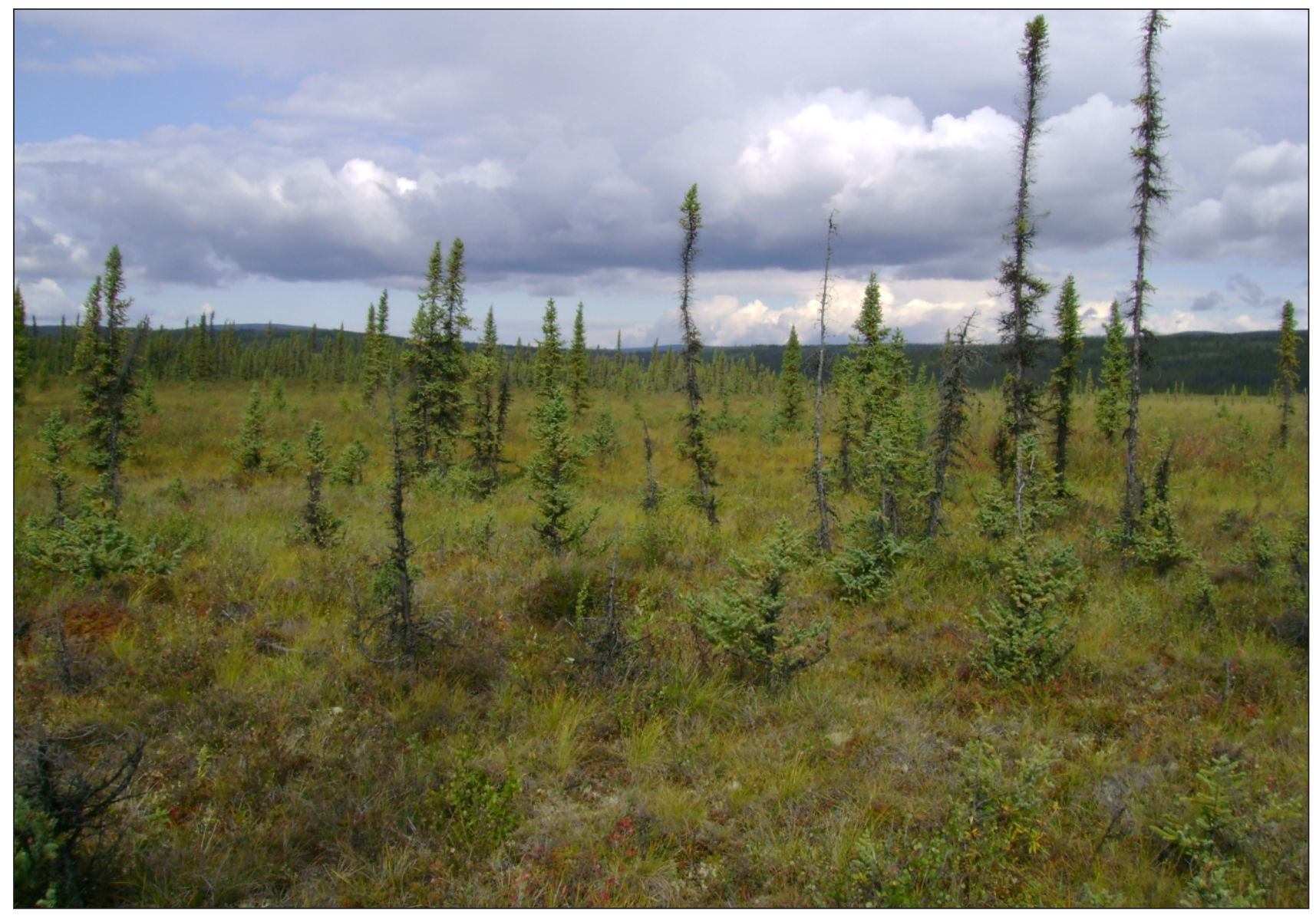

Figure 73. Typical sedge tussock and scattered black spruce vegetation growing above shallow, continuous permafrost on floor of upper Ladue River valley, southern Tanacross B-3 Quadrangle (Reger and Hubbard, 2010, fig. 7). Depth to permafrost is $33 \mathrm{~cm}$. Photograph taken 8/8/2009.

content, depending on the topographic setting and nearby tree cover. Northern and lower eastern and western slopes and valley bottoms with mixed deciduous-coniferous trees are discontinuously frozen with low to moderate ice content. Where vegetated with scattered to dense black spruce, moist shrublands, wet sedge meadows and sedge tussocks, and peat bogs, lowermost northern slopes and valley bottoms typically are continuously frozen and ice rich (fig. 73).

\section{Open-system pingos}

Widespread on lower slopes and valley bottoms in the southern Yukon-Tanana Upland are permafrost mounds that hydrologically connect to ground water and at full development are cored by an ice lens (Holmes and others, 1968; Reger and others, 2012b) (fig. 74). These pingos form in perennially frozen, fine-grained clastic sediments where a suitable subsurface plumbing system exists, including (1) extensive upland intake areas that supply precipitation and runoff waters to the groundwater sys- tem, (2) gentle to moderate slopes to establish hydraulic gradients, (3) intrapermafrost or subpermafrost drainageways through taliks, and (4) local areas of groundwater emergence (Holmes and others, 1968; Ferrians, 1988; French, 2007). Pingos evolve through a morphological sequence from small, ice-cored mounds through obvious small knobs supporting robust trees of the boreal forest to circular ponds and lakes (fig. 75). A subsurface ice lens, which is the core of a pingo, initially forms at a fairly shallow depth in permafrost where groundwater under artesian pressure is prevented from reaching the ground surface by near-surface frozen ground. Hydrostatic stresses and growth of the ice lens initially dome the overlying ground to form a low mound, and the surface vegetation is unaffected by significant drainage changes (fig. 75A). During the next several decades to centuries, lens growth continues, and pingo relief increases to form a small hill (fig. 75B). During the process, small concentric and radial cracks develop in the seasonally thawed sediments above 


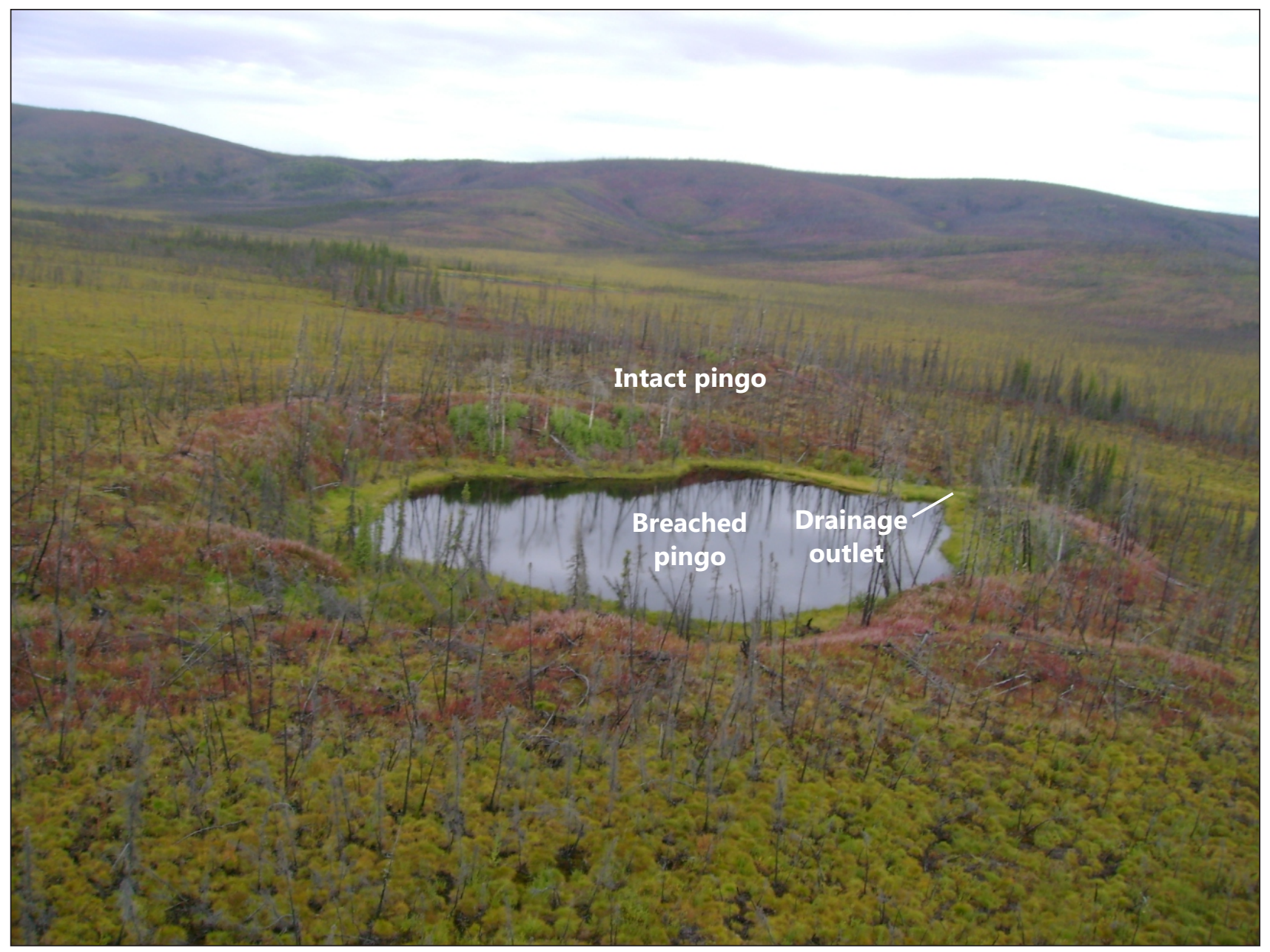

Figure 74. Pair of open-system pingos on perennially frozen lower slope of upper Ladue River valley, southern Tanacross B-3 Quadrangle (Reger and Hubbard, 2010, fig. 8). High relief of rear pingo indicates ice core is intact. Pingo in middle ground has collapsed, and coldwater springs feed crater pond, which drains through breach in remnant pingo rim. Sedge tussocks dominate vegetation in foreground where wildfire recently destroyed the tree cover. Photograph taken 8/19/2009.

the expanding ice lens in the summit of the pingo, and vegetation adapts to better soil drainage and deepening permafrost. Ultimately, summit cracks widen enough that the ice core is exposed to atmospheric temperature variations, and the top of the ice core begins to melt at the summit each summer, initially forming a shallow depression. At this stage, maximum relief has been achieved and growth ceases. The shallow summit depression gradually deepens and expands to form a summit crater through slumping of concentric blocks (fig. 75C). Springs in the floor of the crater supply cold water to the crater, gradually melting the underlying ice core. A mature boreal forest survives on the pingo, typically in marked contrast to the sedge tussocks, shrubs of resin birch and willows, and scattered, stunted black spruce trees in the scrublands around the pingo, where permafrost is shallow. Eventually, after several decades to centuries, the expanding pond breaches its confining walls and is the source of a surface drainage network (fig. 75D). During succeeding decades and centuries, the ice core gradually disappears. Concurrently, the crater walls decrease in height, and eventually only isolated low remnants of the former crater rim remain. Remnants of the clump of trees that formerly existed on the pingo hill survive on these stable mounds (fig. 75E). Typically, a shallow, spring-fed, circular pond persists where the ice core formerly existed and is gradually filled by peat in marshes that encroach from the upslope side and gradually become perennially frozen. Dating of pingo sediments in interior Alaska demonstrates that they evolved during the Holocene (Holmes and others, 1968). 


\section{Lithalses}

On valley floors in the southeastern corner of the Alaska Highway corridor, lithalsas are mapped as broad, low mounds with circular to elliptical outlines that are composed of perennially frozen retransported silt and sand and lack surface peat (Reger and others, 2012b) (sheets 6 and 12). Physiographic relations demonstrate that the mounds postdate small streams that cross them, indicating that they are not sand dunes. Heights of lithalsa mounds are a function of the aggregate thicknesses of segregated ice lenses that accumulate in thickening permafrost, where groundwater is drawn to a slowly advancing freezing front (Camels and Allard, 2008; Camels and others, 2008). In contrast, the height of an open-system pingo mound is equivalent to the thickness of its central ice lens (fig. 75). Like open-system pingos, lithalsas evolve through a series of surface forms. Surface disturbances of the permafrost, like wildfires or stream erosion, initiate thawing of the permafrost, collapse of the lithalsa mound, and the eventual formation of a thermokarst pond (Wolfe and others, 2014). Canadian studies indicate that lithalses typically develop in discontinuous permafrost, where extensive taliks allow the passage of groundwater through permafrost to freezing fronts (Wolfe and others, 2014). Our airborne-resistivity data indicate that the lithalsas in the southeastern corridor are developed in discontinuous permafrost with medium to low ice content (sheet 12).

\section{Upland permafrost south of the Tanana Lowland}

Widespread discontinuous alpine permafrost is inferred at higher elevations in the eastern Alaska Range because of colder temperatures at higher elevations. For example, using the air-temperature lapse rate at Northway $\left(0.8^{\circ} \mathrm{C} / 100 \mathrm{~m}\right)$ (Péwé, 1975a, table 14$)$ as a tentative basis, the mean annual temperature on Macomb Plateau is projected to be $-6.8^{\circ} \mathrm{C}$ to $8^{\circ} \mathrm{C}$ colder than in the nearby Tanana River valley. These climatic conditions and the discontinuous cover of snow during the Donnelly glaciation probably produced widespread, shallow permafrost on the plateau. The wide distribution of patterned ground and the efficiency of gelifluction in reworking glacial deposits and frost-rived bedrock to form smooth, gentle slopes, even on slopes as shallow as 1 degree, imply that permafrost is continuous on the plateau and fairly shallow (fig. 10). Limited observations of the banks of thaw ponds and thaw lakes indicate that the blanket of unconsolidated organic silt with some sand and scattered pebbles, cobbles, and boulders produced by reworking of Delta drift on the plateau is frozen below $0.5 \mathrm{~m}$ and is locally ice rich to depths of at least $2 \mathrm{~m}$. Small spruce trees submerged in shallow water along the margins of the ponds and fresh sediment exposures are evidence that the ponds are expanding. Permafrost is likely discontinuous with low to very low ice content in bedrock tors, rubble sheets, and steep canyon walls, although foliated and intensely fractured rocks may be locally ice rich below the active layer. Colluvial-alluvial fans at the mouths of northern valleys of Macomb Plateau are probably discontinuously frozen with low ice content, except that shrub and sedge vegetation in fine-grained distal zones indicates the presence of continuous permafrost.

Fills in tributary valleys are composed of the reworked, sandy and granular weathering products (grus) derived from granitic bedrock ridges and incorporated organic micaceous silt (lowland loess) (Reger and others, 2008a). Shrubby vegetation (fig. 76) and the presence of opensystem pingos indicate that permafrost in these valley fills ranges from continuous to discontinuous, and ice content ranges from low to moderate. In test pits dug into organic silts, ice is present as small, isolated clear crystals. Depth to permafrost is 0.5 to $0.6 \mathrm{~m}$.

We anticipate that alpine permafrost is discontinuous with low ice content where slopes are moderate to steep and well drained and bedrock is shallow. No attempt was made to separate possible sporadic permafrost with low ice content, which is likely present in very steep, south-facing rock walls, from discontinuous, perennially frozen ground. However, in active rock glaciers, massive talus cones, protalus lobes, and ice-cored Holocene moraines that occupy topographic settings at least partly sheltered from direct solar radiation, continuous permafrost is inferred to have low to moderate ice content (Reger and Hubbard, 2010). Coarse glacial drift in mountain valleys is inferred to contain discontinuous permafrost with low ice content.

\section{Unstable slopes}

Slope failures represent a local hazard in four geologic settings: (1) in frozen retransported loess and eolian sand, (2) in colluvium, (3) in weathered granitic bedrock, and (4) in schist bedrock (Reger and others, 2012a).

Near AMPs 1265-1267, three large, retrogressive landslides are expanding headward toward the Alaska Highway from southwest-facing bluffs of the Chisana River by the thawing of discontinuously frozen retransported loess and eolian sand with low to moderate ice content (sheets 


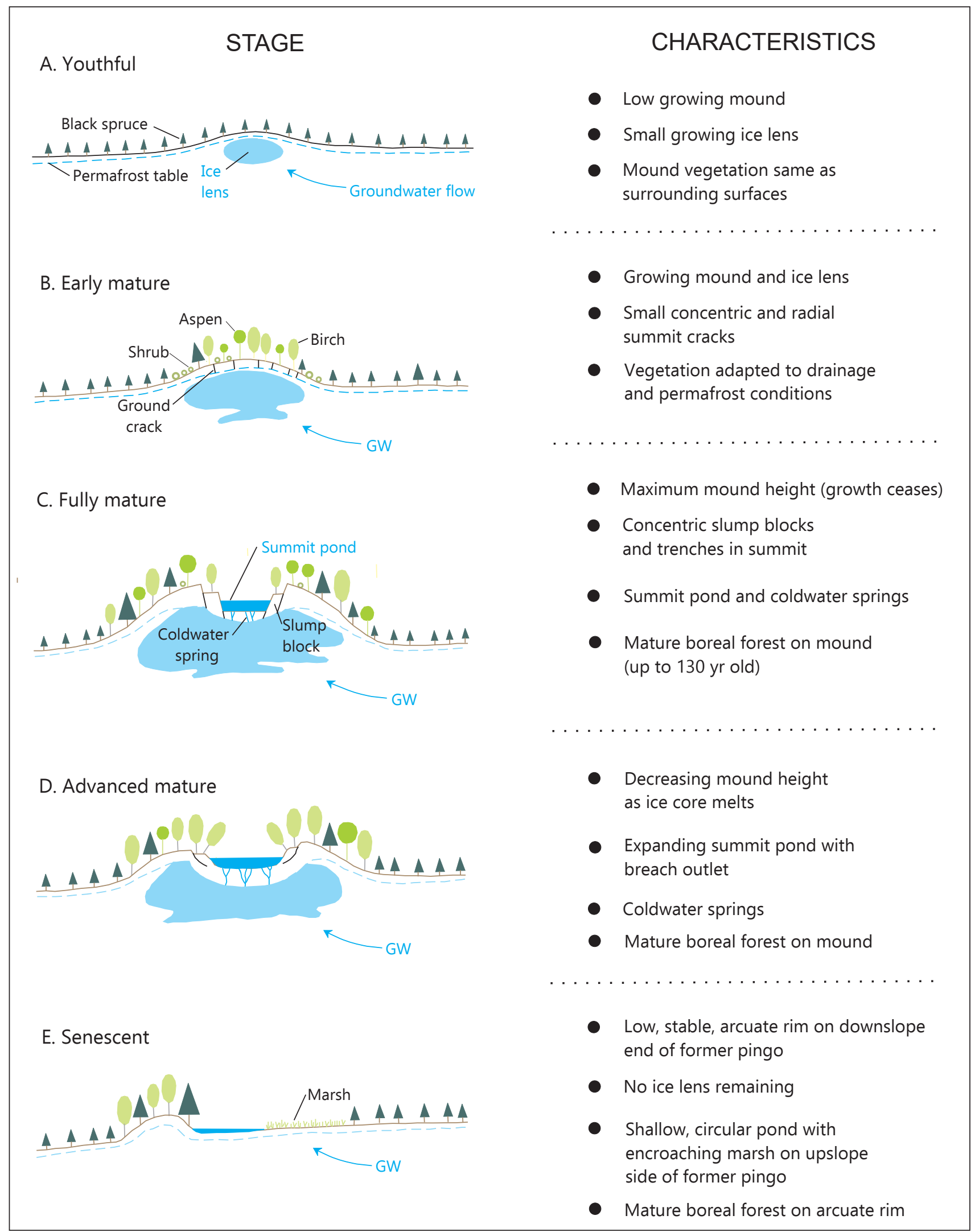

Figure 75. Evolution of open-system pingos (developed from Holmes and others, 1968) (Reger and Hubbard, 2010, fig. 9). 
5 and 11). Those slope failures were probably initiated by stream erosion along the northeastern margin of the Chisana River floodplain and are dominated by complex slumping of blocks of thawing perennially frozen sandy silt. The large failure near AMP 1267 seriously affected the Alaska Highway, and in 2004 required moving the highway alignment northward away from the Chisana River floodplain (fig. 77). Cracks that subsequently developed in pavement emplaced in the summer of 2008 and in adjacent fill along the Alaska Highway near AMP 1267 demonstrate continuing northward expansion of the retrogressive failure. An analysis of tree cores on the landslide indicates that widespread instability and movement were initiated in the late 1980s (Stewart and others, 2017).

Between AMP 1329.3 and AMP 1330.0, a small landslide in colluvium is causing chronic maintenance problems along the Alaska Highway (Reger and others,
2011 , sheet 3 ). The probable cause of this active instability is the thawing of permafrost, but episodic activity along the Cathedral Rapids fault in this area could be a secondary factor.

A moderate-sized failure in weathered granitic bedrock is active on the 40-m-high north wall of Gardiner Creek canyon in the west-central Nabesna D-1 Quadrangle (fig. 78 ; sheet 6 ). The surface of the slide body is laced with numerous fresh, arcuate scarps, indicating that internal displacements are by complex rotational slumping (Reger and others, 2012a). The permafrost table is $90 \mathrm{~cm}$ deep in the open woodland of scattered quaking aspen behind the crown of the failure and $36 \mathrm{~cm}$ deep $-50 \mathrm{~m}$ behind the slide crown in dense black spruce forest. This slide was likely initiated by thawing of permafrost in the south-facing canyon wall.

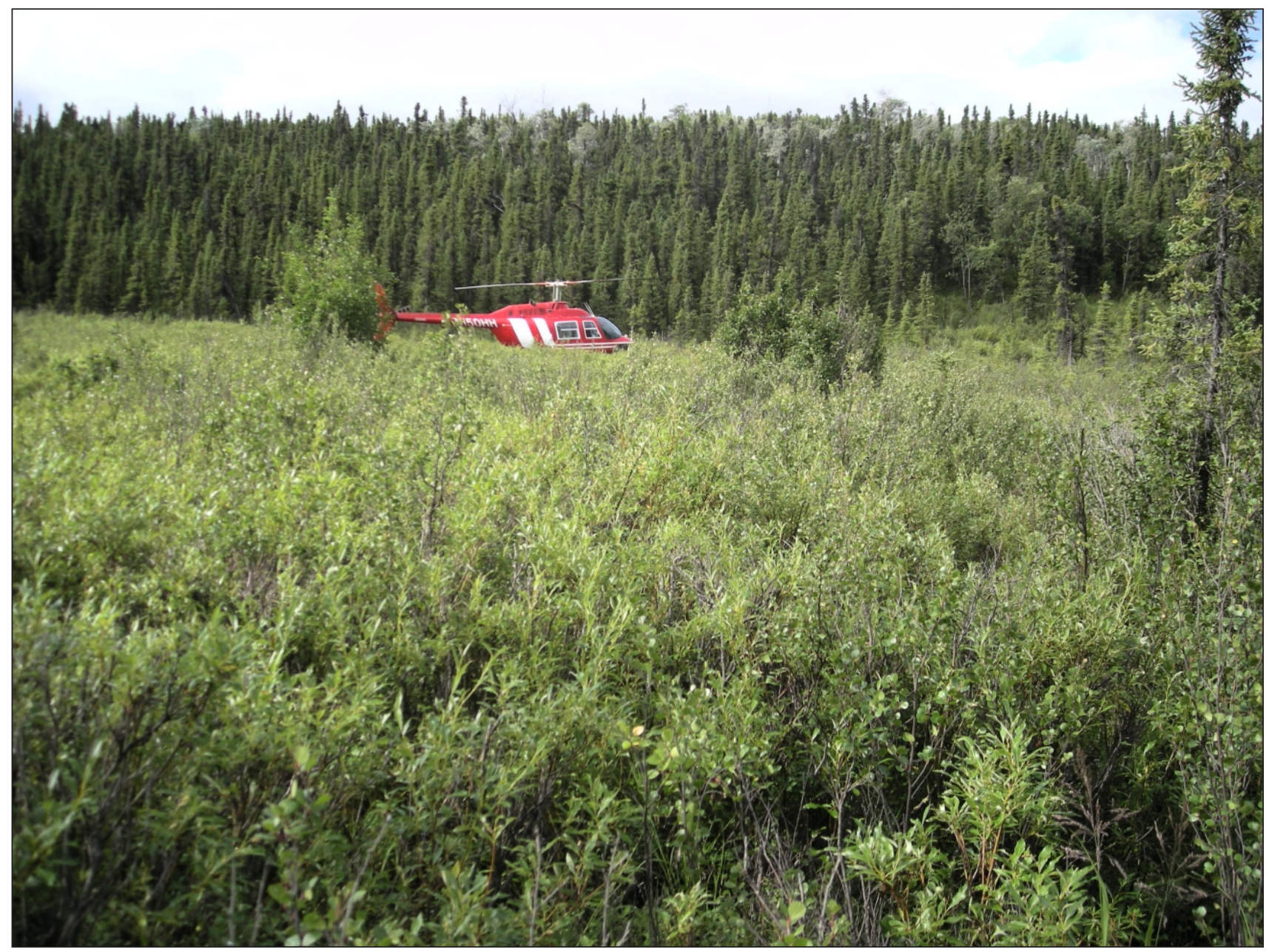

Figure 76. Dense willow and resin birch shrubs with scattered stunted black spruce trees in foreground growing on perennially frozen colluvial-alluvial fill in valley bottom, east fork of Berry Creek, northwestern Mount Hayes C-1 Quadrangle (Reger and Solie, 2008a, fig. 4). Dense black spruce cover on south valley wall in background. Photograph taken 7/20/2007. 
Along the Canada border east of upper Desper Creek in the southwestern Nabesna D-1 and northeastern Nabesna C-1 quadrangles, two small slides occurred between -760 and $-1,070 \mathrm{~m}$ elevation on steep, east- and west-facing slopes in schist bedrock (sheet 6) (Richter, 1976; Reger and others, 2012a). Other small, shallow slides are present along the southern margin of the Yukon-Tanana Upland where river erosion has undercut steep bedrock slopes.

\section{Holocene flooding}

Holocene flooding of the upper Tanana River is associated with summer and fall cyclonic storm cycles, summer melting of alpine snow and ice fields, and the winter buildup of massive floodplain icings. Seasonal flooding across the broad alluvial apron southeast of Delta Junction, which potentially threatens local agricultural developments, is managed by flood-control structures. Cold-weather flooding in the Delta Junction area results from the damming of the braided Jarvis Creek floodplain by the buildup of stream icings and the diversion of lower Jarvis Creek (Reger and Péwé, 2002). Extensive stream icings develop each winter on the broad, braided floodplains of the Delta, Gerstle, Johnson, and Robertson rivers (fig. 79) (Dingman and others, 1971; Sloan and others, 1976).

In addition to seasonal floods in the Alaska Highway corridor, Holocene inundations by the Tanana River were likely produced by sudden drainages of meltwater lakes like those impounded today by valley glaciers at the heads of the Nabesna, Robertson, Johnson, Gerstle, and Delta rivers and Bear and Berry creeks (Post and Mayo, 1971). The suite of landforms that resulted from Holocene flooding in the upper Tanana River includes the floodplains of major tributary streams that are inset into Donnelly glaciofluvial landforms, numerous expansion fans deposited by the flooding Tanana River and their associated natural-levee and crevasse-splay complexes, impounded

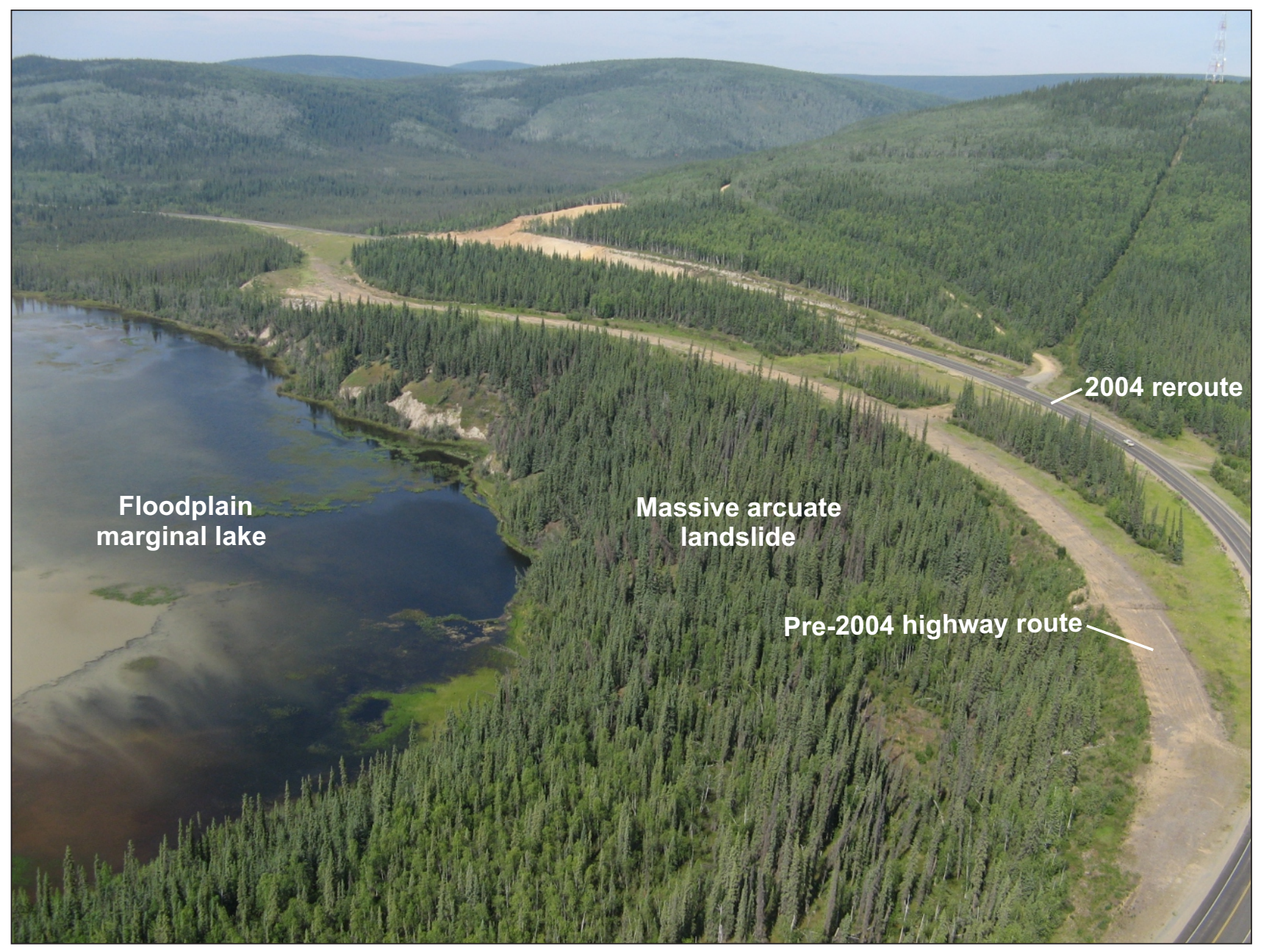

Figure 77. Aerial view northwestward of large, arcuate, thaw-induced, retrogressive failure that intersected the Alaska Highway near AMP 1267 and required highway rerouting in 2004 (Reger and others, 2012b, fig. 10). Photograph taken 7/31/2009 by R.A. Combellick. 


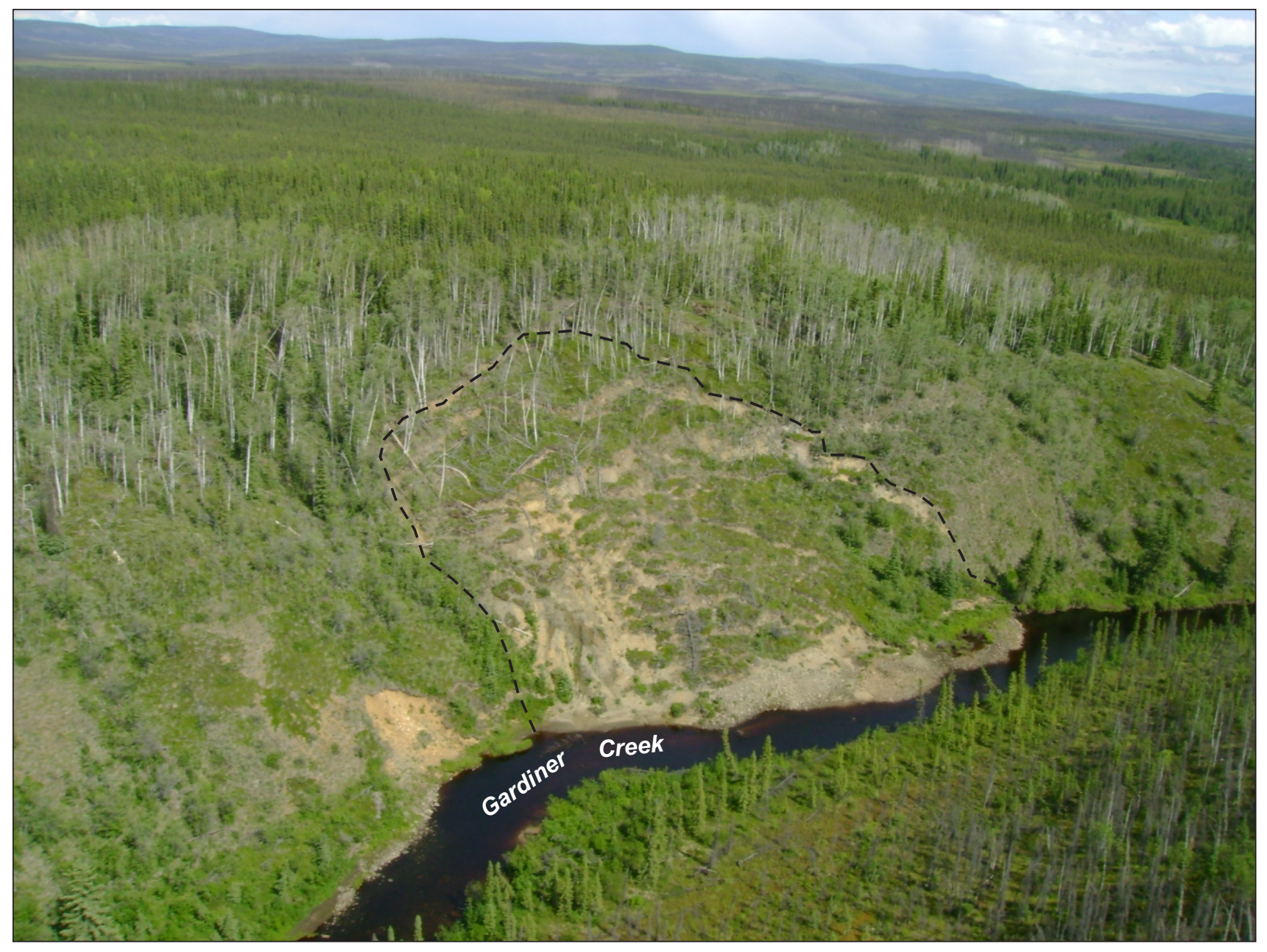

Figure 78. Aerial view of moderate-sized, active failure in weathered granitic bedrock on northern wall of Gardiner Creek canyon, central Nabesna D-1 Quadrangle (Reger and others, 2012a, fig. 17). Slide margin marked by dashed black line. Photograph taken $7 / 23 / 2009$.

slackwater basins outboard of these expansion fans, and extensive erosion escarpments that cut Donnelly features.

The Tok River alluvial fan is inset 4.8 to $10 \mathrm{~m}$ into the coarser jökulhlaup sediments of the older Tok expansion fan (Reger and others, 2011). The Tok River fan surface is covered with meandering and anastomosing former channels that are visible through a thin cover of loess (fig. 21; sheet 4). Surface morphology indicates that the fan shape was produced by sudden shifts of the Tok River meander belt (avulsions) during periodic floods (Allen, 1965). Thus, the Tok River alluvial fan was built by the normal activities of the Tok River, not by the extraordinary jökulhlaup floods that deposited the Tok expansion fan to the west. Much of the younger alluvial fan surface is abandoned floodplain that is subject to periodic flooding and is poorly drained. Surfaces of active, inactive, and abandoned floodplains are capped by up to $-15 \mathrm{~cm}$ of loess above a layer of fine-grained overbank alluvium that overlies sandy pebble bedload gravel, and the surfaceweathering profile is weakly developed (Reger and others, 2011, fig. 25). Channel fills of sand and sandy pebble gravels typically display cross-bedding (fig. 80). Foster (1970) assigned the Tok River alluvial fan to the Donnelly glaciation, and Carrara (2006) dated it as late Pleistocene and Holocene. A sample of grass and bark from a depth of $3 \mathrm{~m}$ in overbank sands in an abandoned channel of the Tok River dates $2,540 \pm 40$ RC yr B.P. (2,620 cal. yr B.P.) (Beta 252318) (table 1; sheet 4, RC 32), demonstrating that those deposits of the Tok River alluvial fan are late Holocene in age. Although the extensive discontinuous scarps along the margins of the floor of the Tok River valley upstream of the Tok River fan were eroded primarily by late Pleistocene outburst floods, they were also affected by floods as young as the Holocene. 


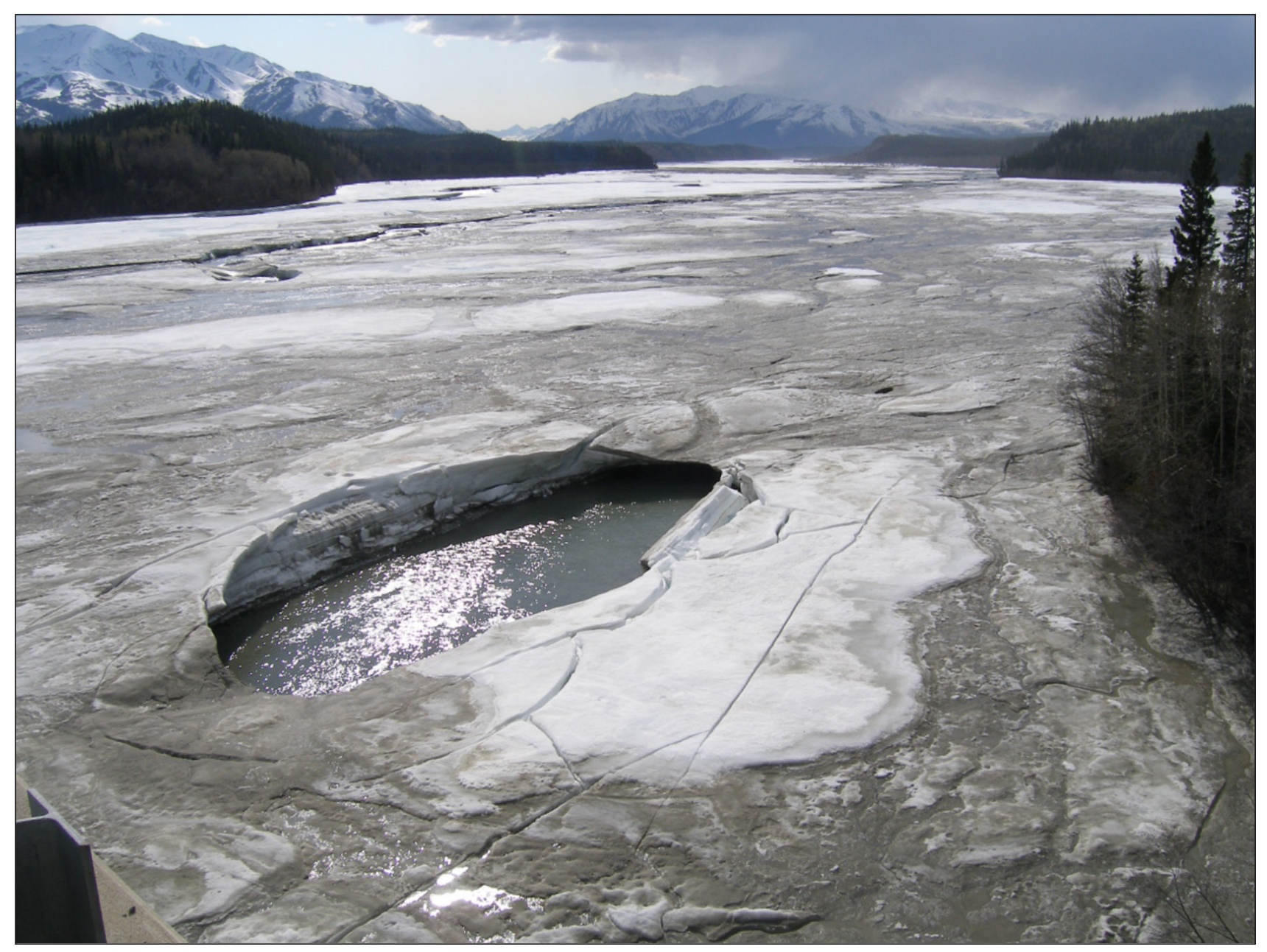

Figure 79. View westward up Robertson River from north end of highway bridge, showing thick winter stream icing on braided floodplain, northwestern Tanacross B-6 Quadrangle. Photograph taken 5/18/2012.

Distal expansion of the Tok River alluvial fan constrained the Tanana River against the bedrock of the southern Yukon-Tanana Upland, raising the local base level and producing upstream an 8- to 28 - $\mathrm{km}$-wide riverine lowland that separates the easternmost Alaska Range and the southern Yukon-Tanana Upland (Wahrhaftig, 1965). This elongate lowland is dotted with myriad lakes and marshlands through which thread the sloughs and channels of the Tanana, Nabesna, and Chisana rivers. The summer of 2009 was particularly warm and sunny, which accelerated melting of alpine snow and ice fields draining into the upper Chisana and Nabesna rivers. Enough meltwater was released to cause widespread flooding of major tributaries of the Tanana River in the eastern Alaska Range (fig. 81). Native subsistence fish camps along streams in the riverine lowland upstream of the Tok River fan were inundated by floodwaters and were temporarily abandoned.
Interpretation of borings drilled for the new bridge over the Tanana River east of Tok indicates that the downstream end of the riverine lowland is underlain by -30 to $41 \mathrm{~m}$ of sand and gravel deposited by the meandering Tanana River (Fitch, 2008). This dominantly fine-grained Holocene alluvium, which is discontinuously frozen beneath the inactive floodplain, overlies $>23$ $\mathrm{m}$ of glaciofluvial gravel with minor sand related to the last major glaciation (fig. 82). About $5 \mathrm{~km}$ downstream from the Tanana River bridge, where the floodplain of the Tanana River is squeezed between the distal edge of the Tok River fan and the southern Yukon-Tanana Upland, fragments of willow wood from a black, woody peat in the abandoned Tanana River floodplain date 1,610 \pm 40 RC yr B.P. (2,400 cal. yr B.P.) (WW-5158) (table 1; sheet 4 , RC 33), locally confirming the late Holocene age of the Tanana River floodplain, as determined far downstream by Mason and Begét (1991) and Mann and others (1995). A 


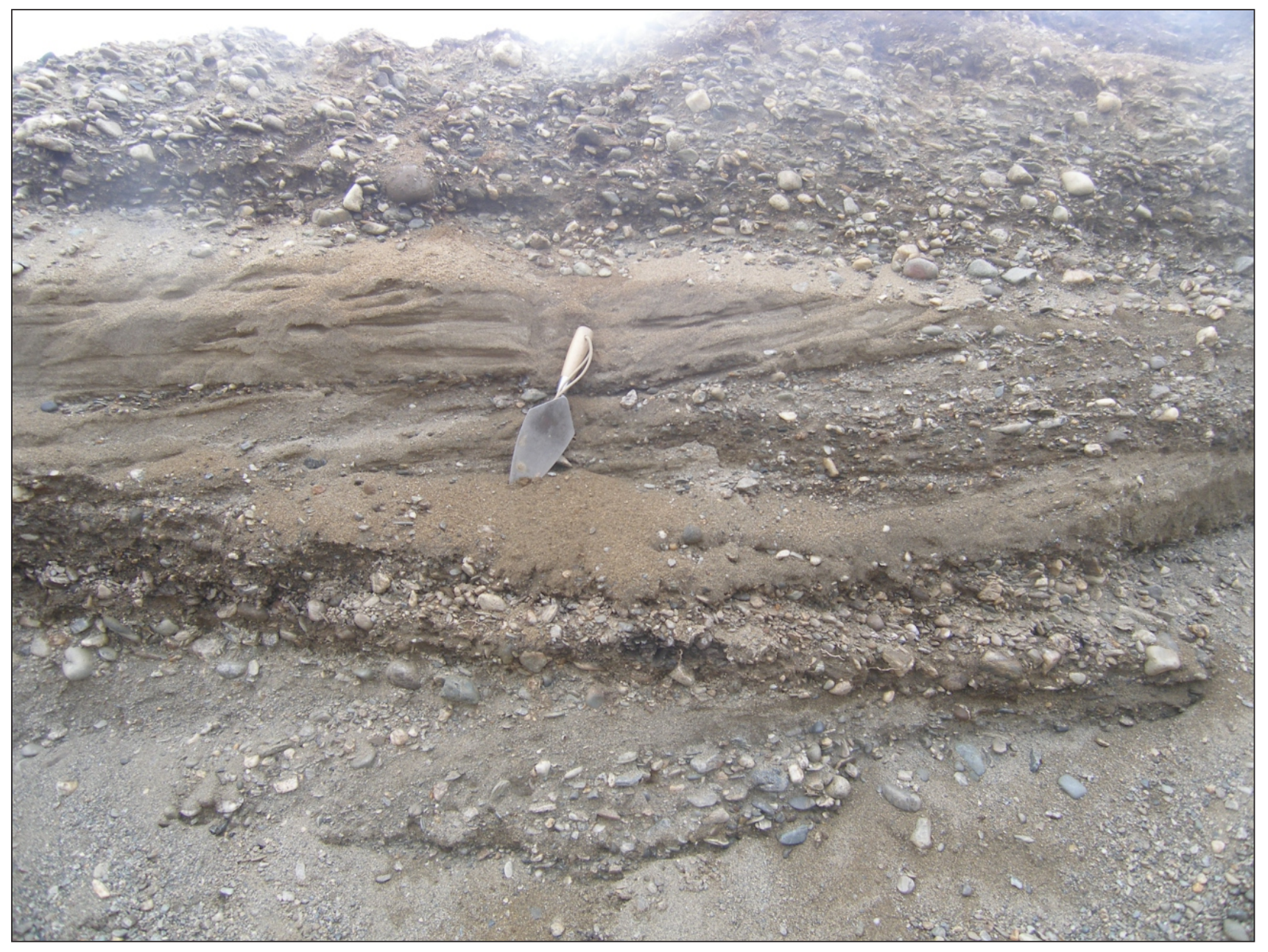

Figure 80. Cross-beds in sand and sandy pebble-gravel fill in shallow channel on Tok River alluvial fan east of Tok River, central Tanacross B-4 Quadrangle (Reger and others, 2011, fig. 26). Sandy pebble gravels beneath channel fill are Holocene bedload deposits of meandering Tok River. Trowel provides scale. Photograph taken 8/19/2008.

nearby terrace -5 to $6 \mathrm{~m}$ above the floodplain is dated at $11,715 \pm 40$ RC yr B.P. (13,520 cal. yr B.P.) (WW-5139) (table 1; sheet 4, RC-34).

Along the northern margin of the meander belt fringing the distal edges of the Tok River alluvial fan and the Tok expansion fan, a series of expansion fans associated with natural levees and crevasse-splay complexes was deposited when sediment-rich Holocene floods in the Tanana River spread outward from their main flood channels across surrounding floodplain surfaces. This flood-sediment complex impounded a series of slackwater basins and associated clearwater lakes, including Fish and Wolf lakes and Lake Mansfield, against the southern Yukon-Tanana Upland (fig. 83). The perennially frozen fine-grained sediments in these slackwater basins typically display concentrations of thaw ponds and thaw lakes and are overlain by or interfinger with lowland loess, eolian sand, retransported loess and sand, and peat (Reger and others, 2008a, 2011). Permafrost is discontinuous to continuous, $<0.9 \mathrm{~m}$ deep, and ice rich, and several basins contain open-system pingos.

Late Holocene flooding of the upper Tanana River is confirmed in paleoseismic trench T 1 near Cathedral Rapids upstream from the mouth of the Robertson River (Koehler and Woods, 2013) (fig. 60). In the east wall of that excavation, flat-lying, bedded, floodplain-marginal silt, fine sand, and gravel in Unit 3 overlie loess capped by a thin, buried soil profile. Detrital charcoal fragments in the buried soil profile date $970 \pm 30 \mathrm{RC}$ yr B.P. $(870$ cal. yr B.P.) (Beta-292210) (table 1; RC-27).

An extensive post-Donnelly, flood-scoured lowland north of Dot Lake Village is bounded to the northeast and south by high erosion escarpments that cut Donnelly jökuhlhaup and proximal outwash deposits (figs. 22 and 25). The large, compound Holocene alluvial fan of Bear 


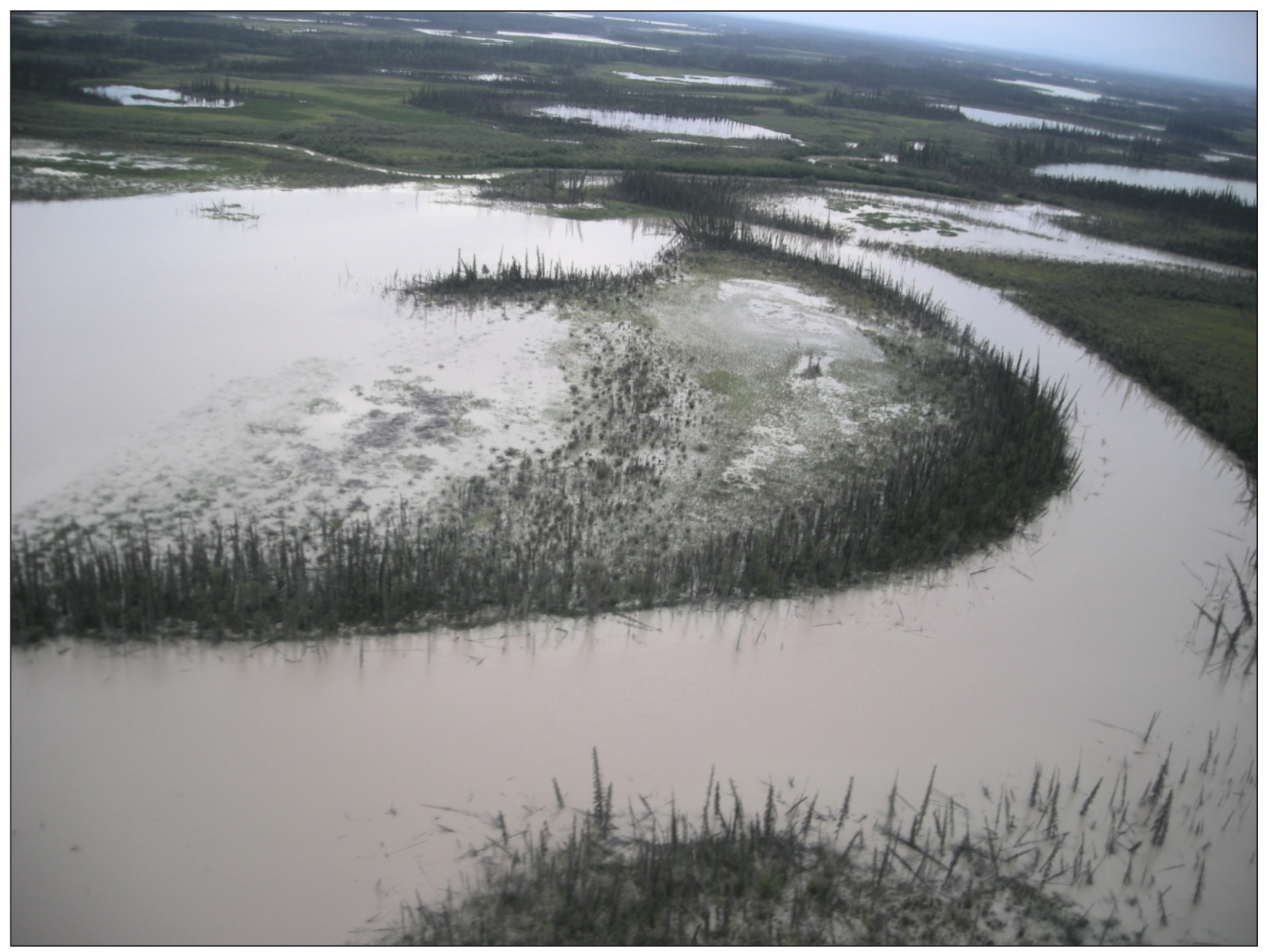

Figure 81. Aerial view northwestward of natural levee and slackwater basin inundated by flooding Chisana River, northwestern Nabesna D-2 Quadrangle. Photograph taken 7/31/2009.

and Chief creeks, which postdates the Dot Lake Village escarpment, blocks the southeastern end of the lowland (Reger and others, 2008a, 2011) (sheets 3 and 4). The source of the Tanana River floods that carved the Dot Lake Village lowland is unknown.

Black Lake has an unusual outline formed by nearly complete filling of the lake basin by flood deposits of late Donnelly and Holocene ages (fig. 84; sheet 2). During Holocene floods of the Tanana River, rising waters flowed east-northeast up flood channels and entered the dumbbell-shaped lake basin at both ends, building small expansion fans. A 58-cm-deep test pit dug into Holocene flood deposits near the channel between the lake basins initially encountered a thin $(7.6 \mathrm{~cm})$ surface loess capping $23 \mathrm{~cm}$ of micaceous fluvial silt representing waning flood deposits. The fluvial silt is underlain by $15 \mathrm{~cm}$ of pebbly, silty sand that overlies clean, sandy, pebble gravel with numerous cobbles, which almost certainly represent material carried in the bedload during Holocene floods. Subangular to well-rounded cobbles measure up to 16 $\mathrm{cm}$ diameter and are concentrated in channel lags. Larger cobbles and boulders prevented deeper excavation.

Short, steep streams draining the northern flank of the eastern Alaska Range are subject to torrential floods during periods of heavy precipitation and have built very coarse colluvial-fluvial fans (Grahek and Livingston, 1983) (sheet 3). Torrential floods were particularly active in the Cathedral Rapids area following three days of heavy rain near the end of spring breakup in May 1997 (Chris Bentele, oral commun., 2008). In some drainages, torrential flooding deposited natural levees up to $1.8 \mathrm{~m}$ high and $7 \mathrm{~m}$ wide that have overridden and pushed over mature birch and spruce trees up to $0.3 \mathrm{~m}$ diameter on both sides of stream channels. Based on principles of tree growth outlined by Scurfield (1973), we sectioned and dated an alder shrub displaying a curved stem in response to tilting by the impact of a debris flow in 1997. The floodplain of 


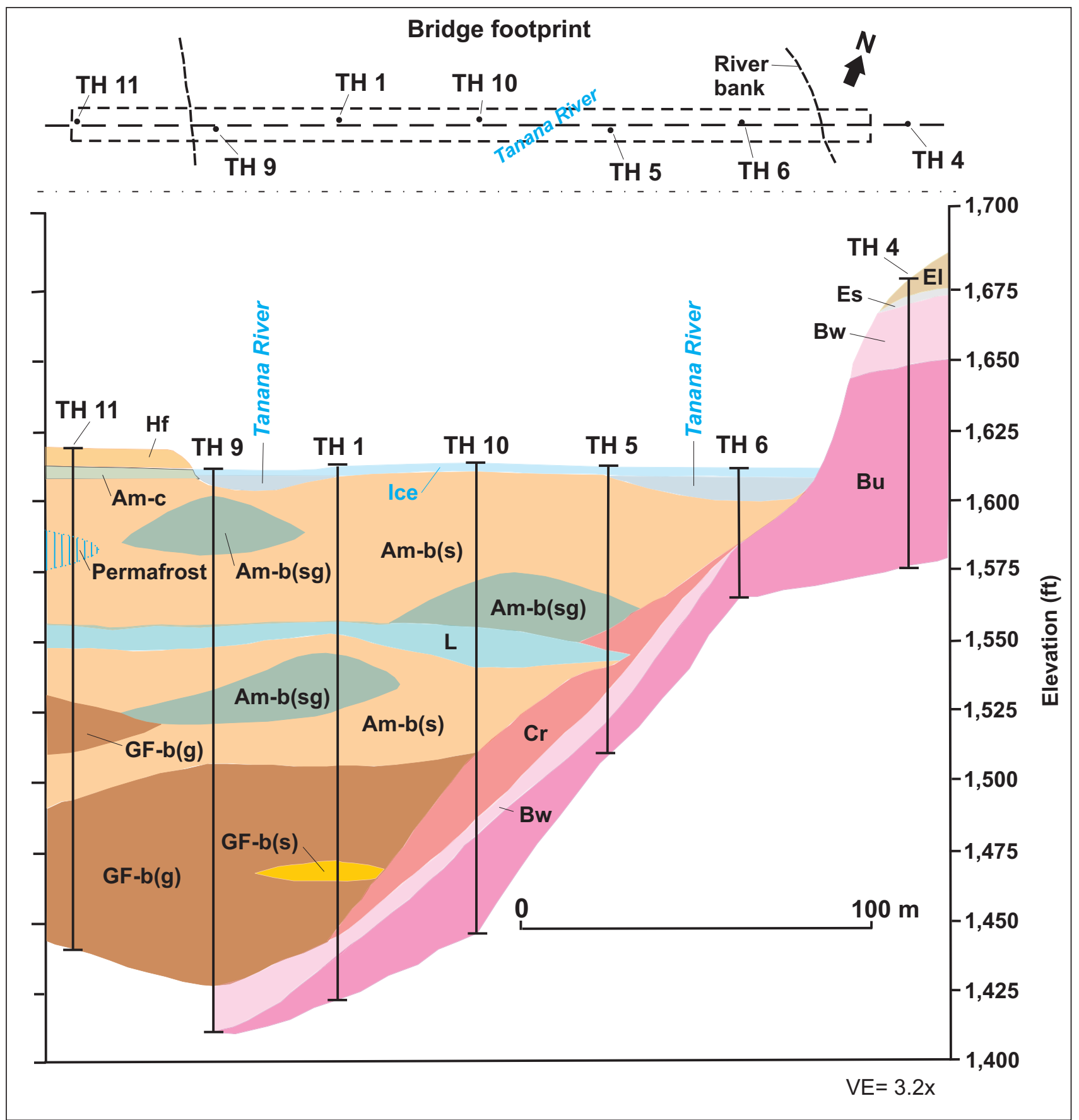

Figure 82. Interpretive diagram based on borings drilled in and near footprint of bridge \#505 over Tanana River at AMP 1303.3, southeastern Tanacross B-4 Quadrangle (Fitch, 2008; Reger and others, 2011, fig. 3). Symbols: Am-c = fine-grained cover sediment in inactive floodplain of meandering Tanana River; Am-b(s) = bedload sands deposited by meandering Tanana River; Am b(sg) = bedload sands with minor pebble gravel deposited by meandering Tanana River; Bu = unweathered to slightly weathered granitic bedrock; $\mathrm{Bw}=$ weathered granitic bedrock; $\mathrm{Cr}=$ granitic colluvium (gravels mixed with grus and fragments of weathered granite); El = loess; Es = eolian sand; GF b(g) = bedload gravels of outwash alluvium; GF-b(s) = bedload sands of outwash alluvium; $\mathrm{Hf}=$ highway fill; $\mathrm{L}=$ lacustrine clays, silty clays, and clayey silts; $\mathrm{TH}=\mathrm{drill}$ hole. Vertical exaggeration 3.2. 


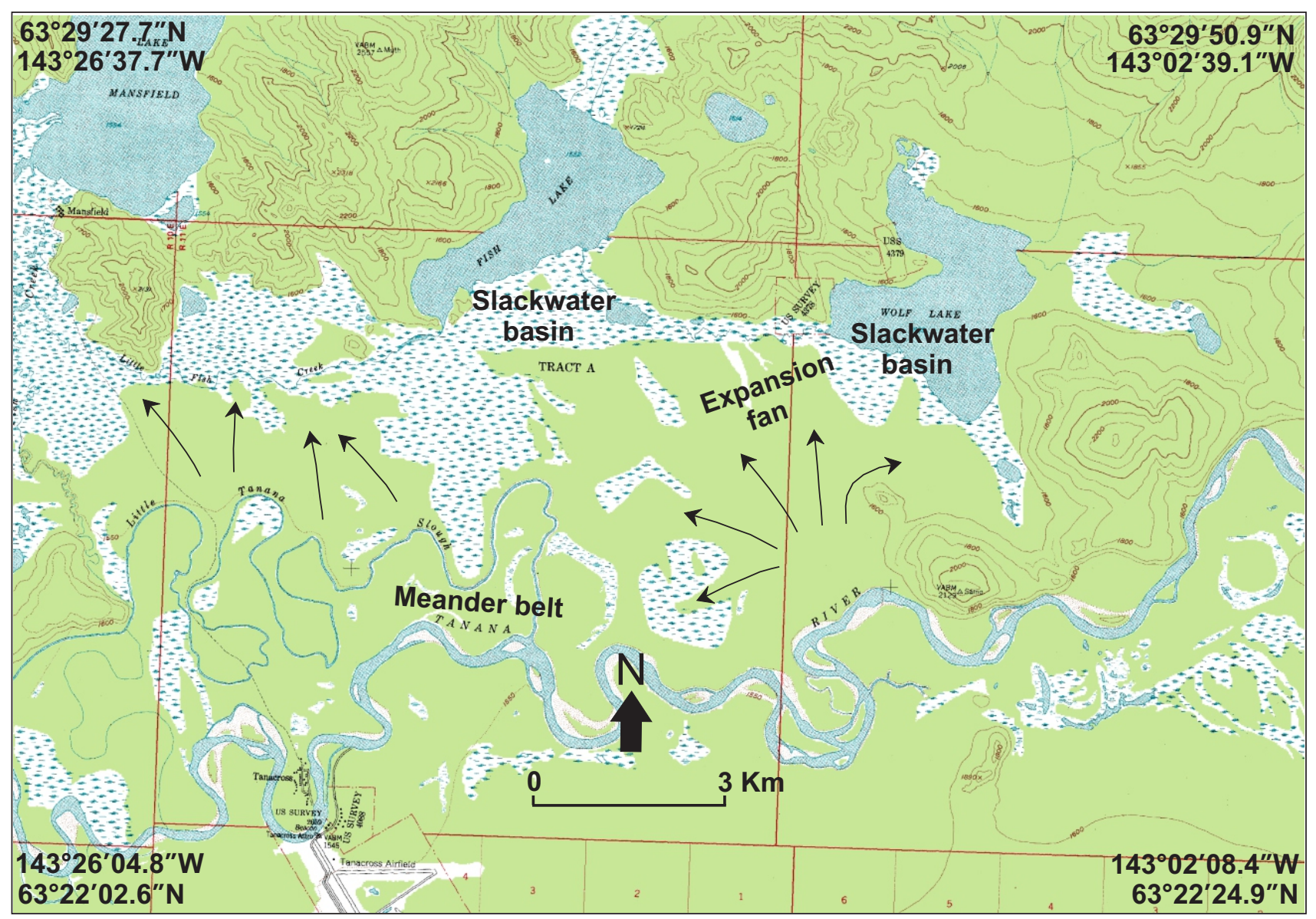

Figure 83. Map showing Holocene expansion-fan and slackwater-basin complex in Fish Lake-Wolf Lake area, north-central Tanacross B-5 Quadrangle (Reger and others, 2011, fig. 2). Arrows indicate general directions of overbank flows.

Yerrick Creek is littered with angular to rounded boulders up to $1.6 \mathrm{~m}$ in diameter and is bordered by coarse natural or artificial levees up to $1.8 \mathrm{~m}$ high and $>4 \mathrm{~m}$ wide (fig. 86; sheet 3 ). Former concrete bridge abutments and large chunks of reinforced concrete scattered across the floodplain downstream from the present bridge are remnants of the former highway bridge that was destroyed by torrential flooding.

\section{SUMMARY}

Between 2006 and 2012, DGGS mapped and evaluated the surficial geology and geohazards in the 19-km-wide and 322-km-long corridor centered on the Alaska Highway between Delta Junction and the Canada border. With little subsurface data available, initial interpretations of July 1978-July 1983 false-color infrared aerial photographs were compared to 2005-2006 airborne-resistivity data and lidar data collected in 2010 and 2011, resulting in more-accurate surficial geology, reconnaissance permafrost, and engineering geology maps. These maps are available in printed form or as seamless coverages in geographic information system (GIS) files.

\section{Glacial history}

This report documents physiographic, stratigraphic, and cosmogenic-exposure evidence in the corridor for glacial expansions correlating with late Cenozoic advances elsewhere in the Alaska Range, Yukon-Tanana Upland, and Yukon Territory. Deposits of the earliest advances are extensively modified and fragmentary, and controversial correlations with early advances in the middle and eastern Alaska Range remain unresolved.

From sources in the eastern Alaska Range, ice expansions of late Pleistocene age spread northward into the southern corridor only as far as the Tanana River. Physiographic evidence and cosmogenic-exposure ages indicate that the delta glaciation actually consists of two glaciations, MIS 4 and MIS 6, separated by an MIS 5 interglaciation (Eva Interglaciation of Péwé and others, 1997). Large glaciers of Delta age advanced down tributary valleys in 


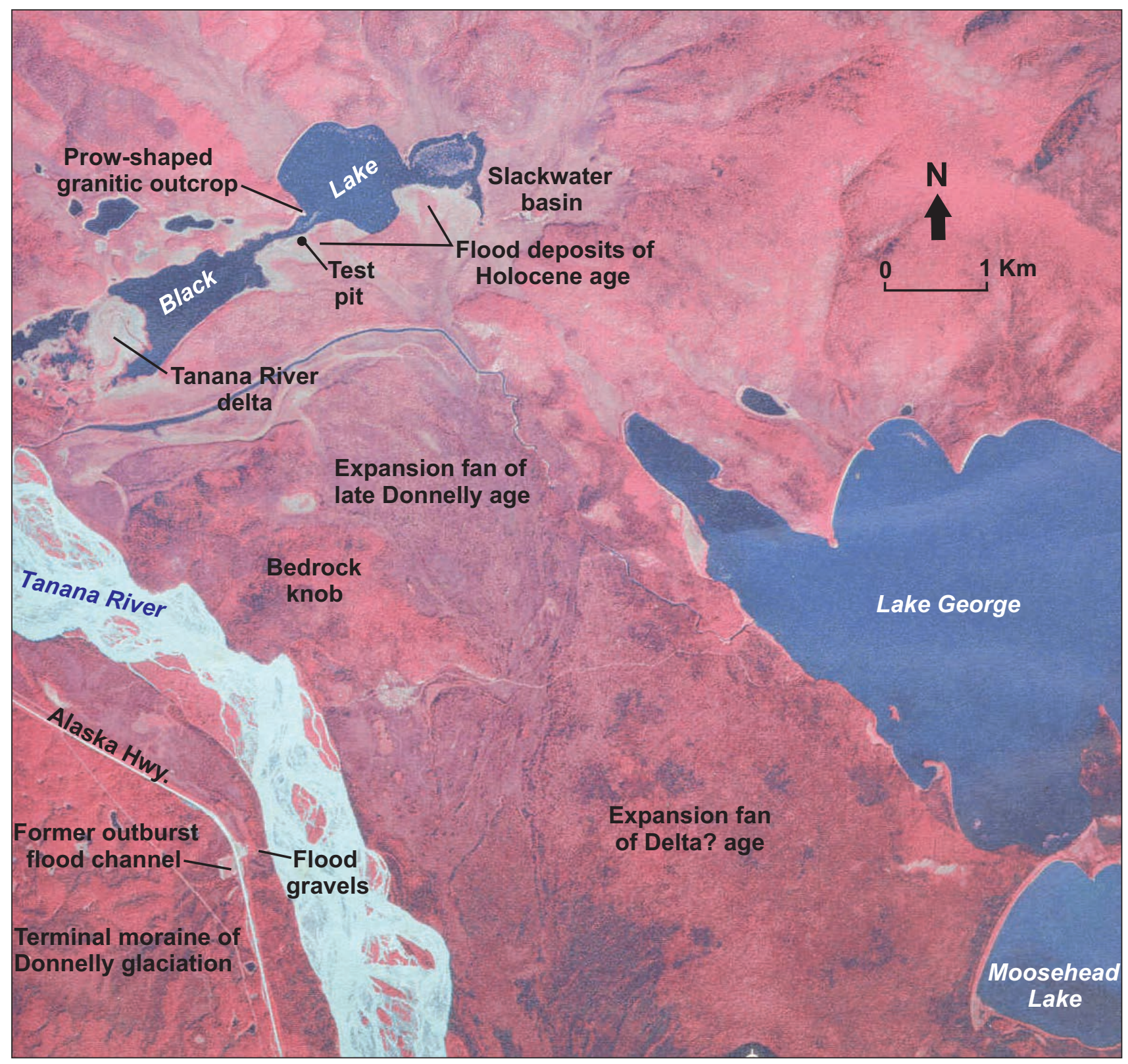

Figure 84. Vertical false-color infrared aerial photograph showing features related to large-magnitude flooding of upper Tanana River in Black Lake area, southeastern Mount Hayes D-2 Quadrangle (Alaska High Altitude Photograph 8621, taken August 1980) (Reger and others, 2008a, fig. 33).

the eastern Alaska Range and spread broad outwash fans northward to the Tanana River. Well-preserved cirques, glacial troughs, moraines, and ice-stagnation deposits, and obvious relations with extensive outwash fans and aprons are characteristic of the Donnelly glaciation. Radiocarbon and cosmogenic-exposure evidence demonstrates that this glaciation is late Wisconsinan (MIS 2) in age. Moraine distributions demonstrate that Donnelly glacial advances were less extensive than Delta advances in the major river valleys of the eastern Alaska Range.
Short Holocene advances in the eastern Alaska Range were limited to alpine valleys above $1,400 \mathrm{~m}$ elevation along the southern margin of the corridor.

\section{Massive paleofloods}

A principal achievement of the DGGS corridor evaluation was our recognition that episodic, massive jökulhlaups had occurred in the upper Tanana River drainage during the Delta and Donnelly glaciations. Physiographic and stratigraphic evidence includes the Tok and other expansion fans, crevasse-splay complexes 


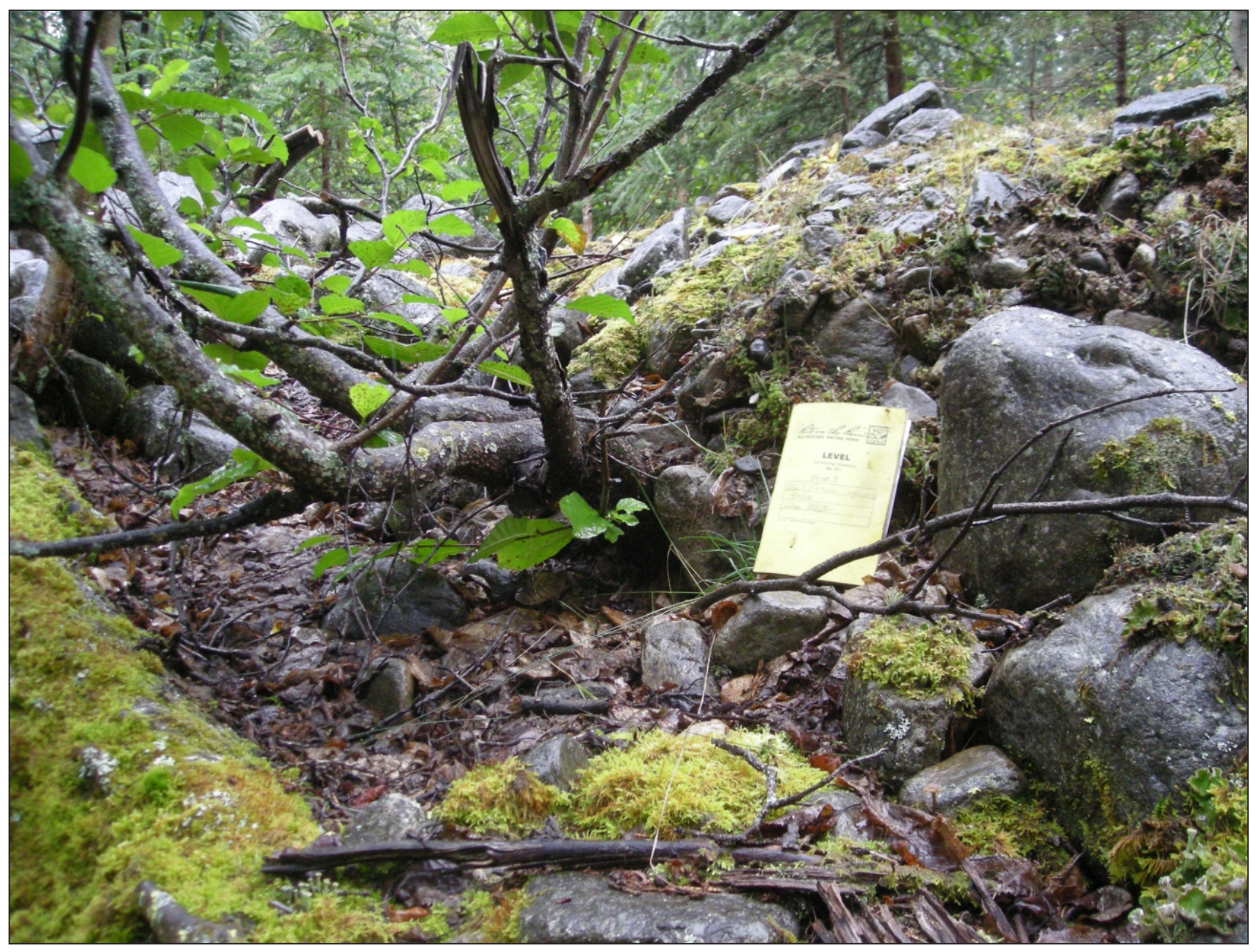

Figure 85. Curved stems of alder shrubs tilted and broken during 1997 deposition of natural levee along unnamed small stream above Alaska Highway, east-central Tanacross B-6 Quadrangle. Field notebook measures 11.4 by 17.8 cm. Photograph taken 9/15/2008.

associated with slackwater basins, streamlined flood terraces and bars, extensive flood escarpments, missing or truncated terminal moraines, hyperconcentrated-flow deposits including massive flood-surge gravels, exceptionally large flood boulders, and flood-scoured bedrock exposures. Based on our investigations we believe Glacial Lake Atna in the northeastern Copper River basin was the primary source of the colossal Tanana River deluges. We found no evidence for jökulhlaups in the Tanana River drainage upstream from the broad Tok expansion fan. We propose that the lack of evidence for glaciation north of the Tanana River is a direct result of the removal of the terminal zones of large valley glaciers tributary to the Tanana River by frequent jökulhlaups.

Modeling based on hydrologic methodology indicates that Delta and Donnelly jökulhlaups had subcritical to near-critical, water-rich or sediment-rich (hyperconcentrated) flows that were capable of eroding and transporting the extensive gravels in expansion fans and flood bars. Extraordinarily large boulders in the flood gravels were likely carried on icebergs.

Radiocarbon ages of small detrital charcoal chunks in basal loess layers overlying the youngest confirmed jökulhlaup sands exposed in paleoseismic trenches indicate that massive outburst flooding ended $\sim 12.8$ ka ago in the Dot Lake-Berry Creek reach of the upper Tanana River valley. However, the sources of extensive Holocene floods in the upper Tanana River have not been identified.

\section{Eolian and related deposits}

During colder phases of the late Pleistocene, strong, cold, density-driven, katabatic winds swept off of the Cordilleran ice sheet in the eastern Alaska Range and down valleys tributary to the upper Tanana River, entraining sand and silt from outwash fans and aprons and active, braidedriver floodplains in nearby lowlands, and transporting them 


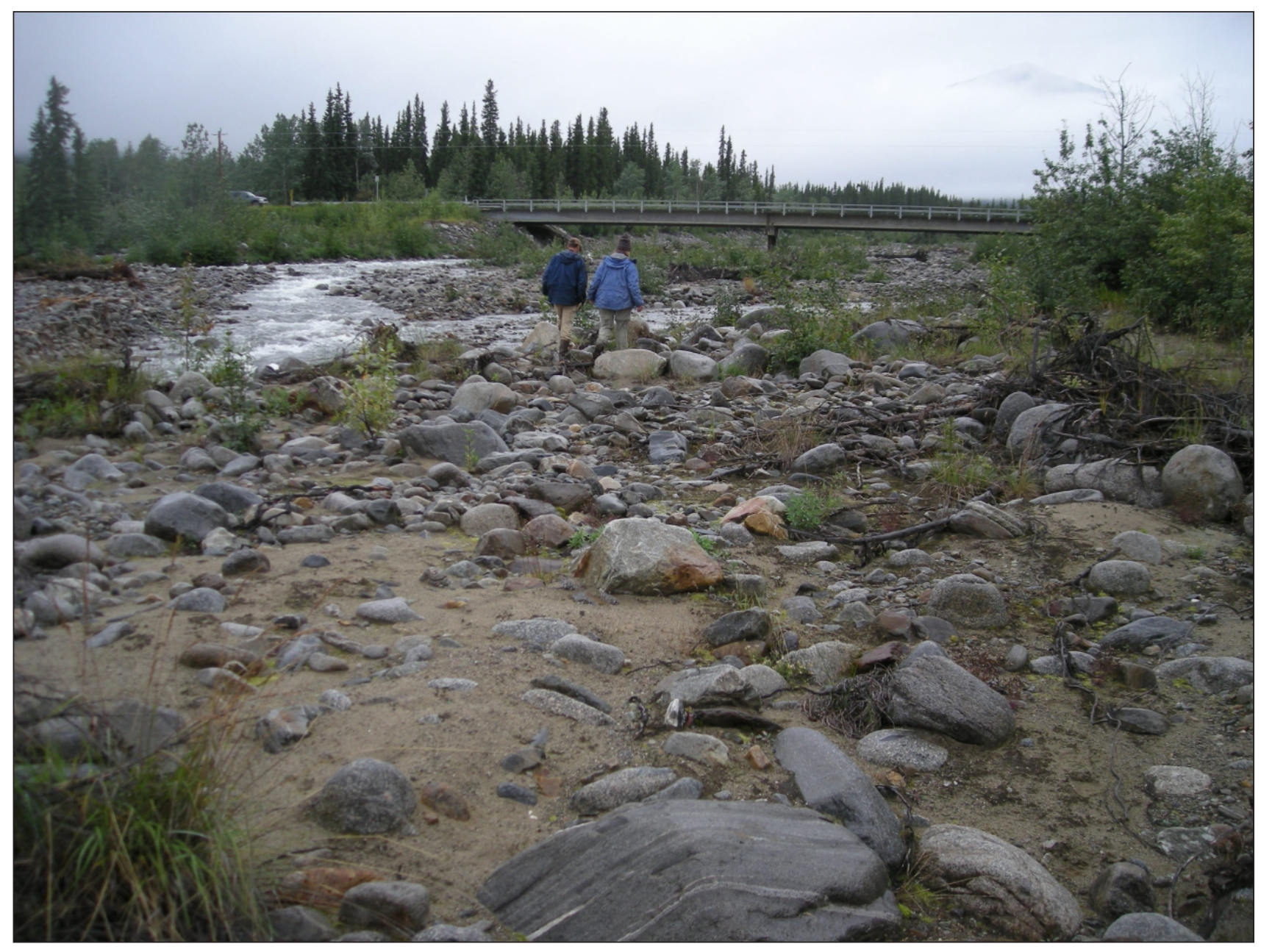

Figure 86. View southward up floodplain of Yerrick Creek toward Alaska Highway bridge, east-central Tanacross B 6 Quadrangle, showing numerous large boulders deposited by torrential flooding. Note reduced summer flow of Yerrick Creek. Geologists provide scale. Photograph taken 7/31/2008.

into the southern Yukon-Tanana Upland. Eolian sand dunes and blankets are overlain by thin loess. Although dune fields are generally vegetated, wildfires episodically destroyed the surface vegetation, reactivating the dunes. Upland sand and loess were retransported primarily by hyperconcentrated flows, surface runoff, and subsurface piping into nearby lowlands to form complex, perennially frozen fills. Several tephras in the eolian sections range in age from 627.5 to $1.1 \mathrm{ka}$. The Tetlin tephra is dated at $627 \pm 47.7 \mathrm{ka}$ (Schaefer, 2002). West of the Gerstle River, discontinuous sand dunes are tan in color and generally unfrozen. In the southern Yukon-Tanana Upland southeast of Tok, eolian sand is gray and generally frozen on lower slopes and in lowlands. Gravimetric soil moisture ranges from 17 to 45 percent in six frozen, eolian sand samples and from 21 to 345 percent in five samples of frozen lowland and retransported loess. During thawing, frozen eolian and retransported sediments become thixotropic.

\section{Periglacial features associated with bedrock}

Seasonal freezing and thawing of bedrock, the formation and decay of bedrock permafrost, and the downslope, gravity-driven mass displacement of the products of bedrock weathering formed colluvial blankets composed of angular bedrock fragments in a silty sand matrix beneath eolian sediments on lower bedrock slopes in the southern Yukon-Tanana Upland. Wedges of colluvium interfinger with coarse alluvial and debris-flow gravels in upland valleys.

\section{Modern geohazards}

Our corridor investigations identified processes and conditions that have the potential to affect future infrastructure development in and near the Alaska Highway corridor, including seismic hazards, permafrost, unstable slopes, and Holocene flooding. 


\section{Seismic hazards}

A major accomplishment during 2006-2011 DGGS paleoseismic reconnaissance investigations was demonstrating that the Northern Foothills Fold and Thrust Belt extends eastward through the southern Alaska Highway corridor as far as the Tok River valley and defines the tectonically active northern margin of the eastern Alaska Range. Geomorphic and stratigraphic evidence permitted identification of five faults, two lineaments that could represent faults, and a large fault-propagation growth anticline, along which there were Holocene displacements in and near the Alaska Highway corridor. Those active seismic structures have the potential to generate future earthquakes that could cause surface-faulting hazards and trigger ground failures in the corridor. However, the evidence collected so far is inadequate to confidently evaluate the individual seismic structures for earthquake magnitudes and recurrence intervals.

Active faults and a possibly active lineament in and near the corridor include the Granite Mountain-Panoramic Creek fault, the Granite Mountain segment of the Dot "T" Johnson fault, the Canteen fault, the Dot Lake segment of the Dot "T" Johnson fault, the Billy Creek fault, the Bear Creek lineament, and the Cathedral Rapids fault with its associated prominent growth anticline. Holocene activity was not confirmed on several other linear features we investigated, which have been suggested as possible active seismic structures: Horn Mountain lineament, Sand Creek lineament, Bear Creek lineament, Mansfield Creek lineament, Dennison Fork and Caribou Creek lineaments, Tetlin Lake lineaments, Ladue River lineament, Midway Lake faults, Northway Junction faults, and the Airs Hills faults.

Severe shaking during future strong earthquakes has the potential for destabilizing saturated, liquefactionprone floodplain sediments and artificial fills in the corridor and causing slope failures on steep slopes, as demonstrated by the 2002 M 7.9 Denali fault earthquake. Site-specific liquefaction-susceptibility and dynamic slope-stability analyses should be undertaken prior to development of any critical or high-occupancy facilities.

\section{Permafrost}

We initially inferred the distribution of permafrost to a depth of $-6 \mathrm{~m}$ by interpreting July 1978-July 1983 false-color infrared aerial photographs. Proxy data included vegetation, slope and aspect, landforms, geology, local drainage, and terrain features such as open-system pingos, lithalses, polygonal ground, thermokarst pits and gullies, and thaw lakes and ponds. The small amount of available published and unpublished subsurface data was incorporated during our investigation. After completion of our initial interpretive permafrost maps, profile models of airborne-resistivity data collected in 2005 and 2006 became available for the corridor east of Tetlin Junction. In the absence of confirming subsurface temperature and borehole data, airborne-resistivity data provided the best available, although indirect, measure of subsurface conditions. We were able to identify zones of different ground resistivity along cross-sectional profiles using a color-formatted, multilayer inversion model (EM1DFM). Based on gravimetric soil moisture content of 11 frozen, near-surface eolian and retransported sand and silt samples, in the resistivity profiles we recognized zones of different ground-ice content in perennially frozen, fine-grained sediments, and compared 63 color profiles that diagonally cross the corridor east of Tetlin Junction with our interpretive permafrost maps. As a result, map unit boundaries were adjusted to better reflect local permafrost conditions, primarily on the floor of the Tanana River valley, where large volumes of groundwater flow through lowland alluvium and taliks are extensive. Interpretations in the southern Yukon-Tanana Upland were generally confirmed by the inversion models. Because we lack borehole confirmation of the subsurface permafrost conditions, except for the meager data in the early cited reports, and the data upon which our interpretations are based vary considerably, our permafrost maps should be considered tentative until they are verified by long-term ground-temperature measurements.

\section{Unstable slopes}

Three large, arcuate, retrogressive landslides, which were likely initiated by bluff erosion along the northeastern margin of the Chisana River floodplain, are expanding toward the Alaska Highway by the thawing of frozen retransported loess and eolian sand near AMPs 1265-1267. The large failure near AMP 1267 seriously damaged the Alaska Highway, requiring a major reroute in 2004. Cracks in the pavement emplaced in summer 2008 and in adjacent fill along the Alaska Highway near AMP 1267 demonstrate continuing northward expansion of the retrogressive failure.

A small active landslide in colluvium between AMP 1329.3 and AMP 1330.0 is probably the result of thawing permafrost, but episodic activity along the nearby Cathedral Rapids fault could be a factor. 
A moderate-sized failure in weathered bedrock is active on the 40-m-high north wall of Gardiner Creek canyon. The slide is apparently moving downslope by complex rotational slumping, probably initiated by the thawing of permafrost in the south-facing canyon wall. Similar shallow landslides are present on steep bedrock slopes undercut by river erosion along the southern margin of the Yukon-Tanana Upland.

These landslides demonstrate that slope instability is an ongoing hazard in the Alaska Highway corridor where slopes are underlain by unconsolidated materials that can be mobilized by active processes such as bluff erosion or thawing permafrost.

\section{Holocene flooding}

Holocene flooding of the upper Tanana River is associated with summer and fall cyclonic storm cycles, summer melting of snow and ice fields, and winter buildups of massive floodplain icings. In addition to seasonal floods, inundations are likely caused by sudden drainages of small, glacier-dammed meltwater lakes in tributary drainages. Post-Donnelly floods produced the floodplains of major tributary streams that are inset into Donnelly landforms, numerous expansion fans, complexes of natural levees and crevasse splays that impound slackwater basins, and extensive erosion escarpments that cut Donnelly features. Radiocarbon evidence demonstrates that the Tok River alluvial fan, which is inset into the Tok expansion fan, is Holocene in age, and was built by the normal activities of the Tok River, not by extraordinary jökulhlaups. Distal expansion of the Tok River alluvial fan restricted the flow of the Tanana River, raising the local base level upstream and producing a riverine lowland dotted with lakes and marshlands.

Short, steep streams draining the northern flank of the eastern Alaska Range between the Robertson River and the Tanacross lowland are subject to torrential floods during periods of heavy precipitation and have built coarse colluvial-alluvial fans.

\section{ACKNOWLEDGMENTS}

Many colleagues in the field and in Fairbanks provided assistance, cartographic and computer support, sample analyses, photographs, and stimulating discussions, including (in alphabetical order): Joe Andrews, Laurel Burns, Sammy Castonguay, Rod Combellick, Gail Davidson, Brent Elliott, Angie Floyd, Larry Freeman, Trish Ekberg, Gerry Griesel, Sharon Hansen, Rainer Newberry, Kyle Obermiller, Joyce Outten, Santosh Panda, Anupma
Prakash, Joni Robinson, Rinu Samuel, Diana Solie, Lauren Southerland, Garrett Speeter, De Anne Stevens, Rhea Supplee, Dave Szumigala, Melanie Werdon, and Rachel Westbrook. While mapping bedrock, geologists Larry Freeman, Rainer Newberry, Dave Szumigala, and Melanie Werdon supplied critical information on the extent of bedrock exposures and frozen ground along their many traverses through the corridor. Special thanks to Janet Schaefer for her helpful response to our questions about the Sheep Creek tephra. Laurel Burns and Gina Graham provided the color-formatted airborne-resistivity sections that were used to calibrate our initial interpretations of permafrost conditions in the corridor between Tetlin Junction and the Canada border. During flying days, we greatly appreciated the skill and dedication of our helicopter pilots: Bill Snyder, Al Holzman, and particularly Tom "Rat" Ratledge, who sometimes had to delay his suppers to bring a field party safely back to camp.

We appreciated the hospitality of the Tanana Loop Country Inn, where we stayed during initial work in 2006. Global Services, Inc., provided a cook for our 2007 camp next to the Johnson River. Through the 2008 and 2010-2012 summer field seasons, friendly hospitality, outstanding professional-quality, home-cooked meals, and comfortable camp facilities were provided at the Cathedral Creeks Bed \& Breakfast by Chris Bentele, her family, and Chef Tim McIntosh. In summer 2009, when our field camp was established at Northway Junction, Chef Karen Johnson prepared delicious, nutritious meals, and ensured that those small extras that make field work really pleasurable were always available in the chow hall.

Glenn and John Burnham, of Burnham Construction, Inc., freely shared their considerable experience and observations of surficial geology in the Tok area and provided copies of local water-well logs. Steve Squires kindly provided the log of the Dry Creek community water well. Discussions of Quaternary glaciations and past environments in the Tok area and information provided by our U.S. Geological Survey colleagues Paul Carrara and Tom Ager have been especially helpful. Our fault mapping and paleoseismic investigations in the Alaska Highway corridor were initiated by Gary Carver (Carver Geologic, Inc., Kodiak, AK), who ably led our program for five years. In addition we received invaluable input from Sean Bemis (University of Kentucky), Peter Haeussler (USGS, Anchorage), Gordon Seitz (San Diego State University), and Ray Weldon (University of Oregon). 
Beta Analytic, Inc., performed all radiocarbon analyses using current AMS methods. The Fairbanks office of Shannon and Wilson, Inc., conducted the sieve analyses of gravel and sand samples from Material Site 62-2-0052. Gravimetric soil-moisture content was determined by Tauriainen Engineering \& Testing, Inc., Soldotna, AK. Vertebrate paleontologists Dale Guthrie (UAF retired) and Patrick Druckenmiller (UAF Museum of the North) kindly identified vertebrate fossil remains encountered during our investigations.
We appreciate permission to access the Tetlin Wildlife Refuge and U.S. Army land as well as private lands of the Tanacross, Doyon, Northway, and Tetlin Native corporations.

We gratefully incorporated thorough edits by Paula Davis and De Anne Stevens and constructive reviews provided by Rod Combellick, Steve Masterman, and Diana Solie, which helped clarify this report. We thank Joni Robinson and Kristen Janssen for contributing their professional layout skills. 


\section{REFERENCES}

Abbott, M.B., and Stafford, T.W., Jr., 1996, Radiocarbon geochemistry of modern and ancient arctic lake systems, Baffin Island, Canada: Quaternary Research, v. 45, no. 3, p. 300-311. http://doi.org/10.1006/ qres.1996.0031

Allen, J.R.L., 1965, A review of the origin and characteristics of recent alluvial sediments: Sedimentology, v. 5, no. 2, p. 89-191. http://doi. org/10.1111/j.1365-3091.1965.tb01561.x

Alyeska Pipeline Service Company (APSC), 1976, Summary report on investigation and evaluation of Clearwater Lake escarpment near Delta Junction, Alaska: Alyeska Pipeline Service Company, Appendix A-3.1111A, v. 1, 113 p., 5 sheets, scale 1:63,360.

Anderson, G.S., 1970, Hydrologic reconnaissance of the Tanana basin, central Alaska: U.S. Geological Survey Hydrologic Investigations Atlas HA-319, 4 sheets, scale 1:1,000,000. https://pubs.er.usgs.gov/ publication/ha319

Anderson, P.M., and Lozhkin, A.V., 2001, The stage 3 interstadial complex (Karginskii/middle Wisconsinan interval) of Beringia-Variations in paleoenvironments and implications for paleoclimatic interpretations: Quaternary Science Reviews, v. 20, no. 1-3, p. 93-125. http://doi.org/10.1016/ S0277-3791(00)00129-3

Andersson, J.G., 1906, Solifluction, a component of subaerial denudation: Journal of Geology, v. 14, no. 2, p 91-112.

Baker, V.R., 1973, Paleohydrology and sedimentology of Lake Missoula flooding in eastern Washington: Geological Society of America Special Paper 144, p. 1-173. http://doi.org/10.1130/SPE144-p1

2009, Channeled Scabland morphology, in Burr, D.M., Carling, P.A., and Baker, V.R., eds., Megaflooding on Earth and Mars: Cambridge, Cambridge University Press, p. 65-77.

Baker, V.R., Greeley, Ronald, Komar, P.D., Swanson, D.A., and Waitt, R.B., Jr., 1987, Columbia and Snake River Plains, in Graf, W.L., ed., Geomorphic systems of North America: Geological Society of America Centennial Special Volume 2, p. 403-468.

Ballantyne, C.K., 2018, Periglacial geomorphology: Chichester, England, John Wiley \& Sons Ltd., 454 p.

Begét, J.E., and Keskinen, M.J., 2003, Trace-element geochemistry of individual glass shards of the Old Crow tephra and the age of the Delta glaciation, central Alaska: Quaternary Research, v. 60, no. 1, p. 63-69. http://doi.org/10.1016/S0033-5894(03)00095-4
Bemis, S.P., 2004, Neotectonic framework of the northcentral Alaska Range foothills: Fairbanks, Alaska, University of Alaska Fairbanks unpublished M.S. thesis, $142 \mathrm{p}$.

Bemis, S.P., Carver, C.A., and Koehler, R.D., 2012, The Quaternary thrust system of the northern Alaska Range: Geosphere, v. 8, no. 1, p. 196-205. http:// doi.org/10.1130/GES00695.1

Bemis, S.P., and Wallace, W.K., 2007, Neotectonic framework of the north-central Alaska Range, in Ridgway, K.D., Trop, J.M., Glen, J.M.G., and O’Neil, J.M., eds. Tectonic growth of a collisional continental margin-Crustal evolution of southern Alaska: Geological Society of America Special Paper 431, p. 549-572. http://doi.org/10.1130/2007.2431(21)

Bender, A.M., Lease, R.O., Corbett, L.B., Bierman, Paul, and Caffee, M.W., 2018, Ongoing bedrock incision of the Fortymile River driven by PliocenePleistocene Yukon River capture, eastern Alaska, USA, and Yukon, Canada: Geology, v. 46, no. 7, p. 635-638.

Berger, G.W., Péwé, T.L., Westgate, J.W., and Preece, S.J., 1996, Age of Sheep Creek tephra (Pleistocene) in central Alaska from thermoluminescence dating of bracketing loess: Quaternary Research, v. 45, no. 3, p. 263-270. http://doi.org/10.1006/qres.1996.0027

Black, R.F., 1976, Periglacial features indicative of permafrost-Ice and soil wedges: Quaternary Research, v. 6, no. 1, p. 3-26. http://doi. org/10.1016/0033-5894(76)90037-5

Blair, T.C., and McPherson, J.G., 1994, Alluvial fans and their natural distinction from rivers based on morphology, hydraulic processes, sedimentary processes, and facies assemblages: Journal of Sedimentary Research, v. 64, no. 3a, p. 450-489. http://doi.org/10.1306/ D4267DDE-2B26-11D7-8648000102C1865D

Bonilla, M.G., and Lienkaemper, J.J., 1991, Factors affecting the recognition of faults exposed in exploratory trenches: U.S. Geological Survey Bulletin 1947, 54 p. https://pubs.usgs.gov/bul/1947/

Braley, Alan, Connor, Billy, Reckard, Matthew, and Zarling, J.P., 1991, Evaluation of Gardiner Creek air ducts: Alaska Department of Transportation \& Public Facilities Report FHWAAKRD9108, 30 p.

Brazo, G.M., 1988, Material site extensions, Supplement 1, Alaska Highway, Johnson River to Dot Lake [Project F-062-2(16)/60229]: Alaska Department of Transportation \& Public Facilities Engineering Geology \& Soils Report, 24 p. 
Briner, J.P., and Kaufman, D.S., 2008, Late Pleistocene mountain glaciation in Alaska-Key chronologies: Journal of Quaternary Science, v. 23, no. 6-7, p. 659-670. http://doi.org/10.1002/jqs.1196

Briner, J.P., Kaufman, D.S., Manley, W.F., Finkel, R.C., and Caffee, M.W., 2005, Cosmogenic-exposure dating of late Pleistocene moraine stabilization in Alaska: Geological Society of American Bulletin, v. 117, no. 7/8, p. 1,108-1,120. http://doi.org/10.1130/B25649.1

Brogan, G.E., Cluff, L.S., Korringa, M.K., and Slemmons, D.B., 1975, Active faults of Alaska: Tectonophysics, v. 29 , no. $1-4$, p. 73-85. http://doi. org/10.1016/0040-1951(75)90134-1

Burgess, S.D., Coble, M.A., Vazquez, J.A., Coombs, M.L., and Wallace, K.L., 2019, On the eruption age and provenance of the Old Crow tephra: Quaternary Science Reviews, v. 207, p. 64-79.

Burn, C.R., and Smith, M.W., 1990, Development of thermokarst lakes during the Holocene at sites near Mayo, Yukon Territory: Permafrost and Periglacial Processes, v. 1, no. 2, p. 161-175. http://doi. org/10.1002/ppp.3430010207

Burns, L.E., Fugro Airborne Surveys Corp., and Stevens Exploration Management Corp., 2006, Line, grid, and vector data and plot files for the airborne geophysical survey of the Alaska Highway corridor, east-central Alaska: Alaska Division of Geological \& Geophysical Surveys Geophysical Report 2006-6, 1 DVD. http://doi.org/10.14509/14864

Busacca, A.J., Begét, J.E., Markewich, H.W., Muhs, D.R., Lancaster, Nicholas, and Sweeney, M.R., 2004, Eolian sediments, in Gillespie, A.R., Porter, S.C., and Atwater, B.F., eds., Developments in Quaternary Science: New York, Elsevier, v. 1, p. 275-309. http://doi. org/10.1016/S1571-0866(03)01013-3

Camels, Fabrice, and Allard, Michel, 2008, Segregated ice structures in various heaved permafrost landforms through CT scan: Earth Surface Processes and Landforms, v. 33, p. 209-225. http://doi.org/10.1002/ esp. 1538

Camels, Fabrice, Delisle, Georg, and Allard, Michel, 2008, Internal structure and the thermal and hydrological regime of a typical lithalsa: Significance for permafrost growth and decay: Canadian Journal of Earth Sciences, v. 45, p. 31-43. http://doi.org/10.1139/ e07-068

Carlson, L.J., and Finney, B.P., 2004, A 13000year history of vegetation and environmental change at Jan Lake, east-central Alaska: The
Holocene, v. 14, no. 6, p. 818-827. http://doi. org/10.1191/0959683604hl762rp

Carrara, P.E., 2004a, Surficial geologic map of the Tanacross B-6 Quadrangle, east-central Alaska: U.S. Geological Survey Scientific Investigations Map 2850, version 1.0, 9 p., 1 plate, scale 1:63,360. http:// pubs.usgs.gov/sim/2004/2850/

2004b, Surficial geologic map of the Tanacross B-5 Quadrangle, east-central Alaska: U.S. Geological Survey Scientific Investigations Map 2856, version 1.0, 9 p., 1 plate, scale 1:63,360. http://pubs.usgs. gov/sim/2004/2856/

2006, Surficial geologic map of the Tanacross B-4 Quadrangle, east-central Alaska: U.S. Geological Survey Scientific Investigations Map 2935, version 1.0, 1 plate, scale 1:63,360. http://pubs.usgs.gov/ $\operatorname{sim} / 2006 / 2935 /$

Carter, L.D., 1980, Tertiary tillites (?) on the northeast flank of Granite Mountain, central Alaska Range, in Short Notes on Alaskan Geology, 197980: Alaska Division of Geological \& Geophysical Surveys Geologic Report 63, p. 23-27. http://doi. org/10.14509/422

Carter, L.D., and Galloway, J.P., 1978, Preliminary engineering geologic maps of the proposed natural gas pipeline route in the Tanana River valley, Alaska: U.S. Geological Survey Open File Report 78-794, 26 p., 3 sheets, scale 1:125,000. http://www.dggs.alaska.gov/ pubs/id/11200

1984, Lacustrine and eolian deposits of Wisconsin age at Riverside Bluff in the upper Tanana River valley, Alaska, in Coonrad, W.L., and Elliott, R.L., eds., The United States Geological Survey in Alaska-Accomplishments during 1981: U.S. Geological Survey Circular 868, p. 66-68. http://dggs. alaska.gov/pubs/id/13424

Carver, G.A., Bemis, S.P., Solie, D.N., and Obermiller, K.E., 2008a, Active and potentially active faults in or near the Alaska Highway corridor, Delta Junction to Dot Lake, Alaska: Alaska Division of Geological \& Geophysical Surveys Preliminary Interpretive Report 2008-3d, 32 p. http://doi.org/10.14509/17901

Carver, G.A., Bemis, S.P., Solie, D.N., Castonguay, S.R., and Obermiller, K.E., 2010, Active and potentially active faults in or near the Alaska Highway corridor, Dot Lake to Tetlin Junction, Alaska: Alaska Division of Geological \& Geophysical Surveys Preliminary Interpretive Report 2010-1, 42 p. http://doi. org/10.14509/21121 
Carver, G.A., Bemis, S.P., Solie, D.N., Obermiller, K.E., and Weldon, R.J., 2008b, Active faults in or near the proposed trans-Alaska gas pipeline corridor, east-central Alaska [abs.]: Seismological Research Letters, v. 79, no. 2, p. 360. http://doi.org/10.1785/ gssrl.79.2.243

Carver, G.A., Plafker, George, Metz, M., Cluff, L., Bemis, S.P., Roddick, J., Redington, J., and Sorensen, S., 2006, Late Quaternary growth of thrust faults and associated folds in the eastern part of the Northern Foothills Fold and Thrust Belt, central Alaska Range, Alaska [poster session presentation]: American Geophysical Union Chapman Conference on Active Tectonics and Seismic Potential of Alaska, 11-14 May 2006, Alyeska Resort, Girdwood, Alaska.

Chapin, F.S., III, Viereck, L.A., Adams, P.C., Van Cleve, Keith, Fastie, C.L., Ott, R.A., Mann, Daniel, and Johnston, J.F., 2006, Successional processes in the Alaskan boreal forest, in Chapin, F.S., III, Oswood, M.W., Van Cleve, Keith, Viereck, L.A., and Verbyla, D.L., eds., Alaska's changing boreal forest: Oxford, England, Oxford University Press, p. 100-120.

Clague, J.J., Ager, T.A., and Mathewes, R.W., 2004, Environments of northwestern North America before the last glacial maximum, in Madsen, D.B., ed., Entering America-Northeast Asia and Beringia before the last glacial maximum: Salt Lake City, University of Utah Press, p. 63-94.

Clague, J.J., Evans, S.G., Rampton, V.N., and Woodsworth, G.J., 1995, Improved age estimates for the White River and Bridge River tephras, western Canada: Canadian Journal of Earth Sciences, v. 32, p. 1,172-1,179. http://doi.org/10.1139/e95-096

Clarke, A.H., 1981, The freshwater molluscs of Canada: Ottawa, National Museums of Canada, 446 p.

Combellick, R.A., 2006, Building a natural gas pipeline through earthquake country: Geotimes, v. 51, no. 11, p. 18-22. http://www.geotimes.org/nov06/feature_ GasPipeline.html

Cossart, E., Braucher, R., Fort, M., Bourlès, D.L., and Carcaillet, J., 2008, Slope instability in relation to glacial debuttressing in alpine areas (Upper Durance catchment, southeastern France)_Evidence from field data and ${ }^{10} \mathrm{Be}$ cosmic ray exposure ages: Geomorphology, v. 95, no. 1-2, p. 3-26. http://doi. org/10.1016/j.geomorph.2006.12.022

Costa, J.E.,1988, Rheologic, geomorphic, and sedimentologic differentiation of water floods, hyperconcentrated flows, and debris flows, in Baker, V.R., Kockel, R.C., and Patton, P.C., eds., Flood geomorphology: New York, John Wiley \& Sons, p. 113-122.
Davies, L,J., Jensen, B.J.L., Froese, D.G., and Wallace, K.L., 2016, Late Pleistocene and Holocene tephrostratigraphy of interior Alaska and Yukon-Key beds and chronologies over the past 30,000 years: Quaternary Science Reviews, v. 146, p. 28-53. http:// doi.org/10.1016/j.quascirev.2016.05.026

Dingman, S.L., Samide, H.R., Saboe, D.L., Lynch, M.J., and Slaughter, C.W., 1971, Hydrologic reconnaissance of the Delta River and its drainage basin, Alaska: U.S. Army Material Command, Cold Regions Research and Engineering Laboratory (CRREL) Research Report 262, 83 p.

Dortch, J.M., Owen, L.A., Caffee, M.W., Li, Dewen, and Lowell, T.V., 2010, Beryllium-10 surface exposure dating of glacial successions in the central Alaska Range: Journal of Quaternary Science, v. 25, no. 8, p. 1,259-1,269. http://doi.org/10.1002/jqs.1406

Douglass, John, Meek, Norman, Dorn, R.I., and Schmeeckle, M.W., 2009, A criteria-based methodology for determining the mechanism of transverse drainage development with application to the southwestern United States: Geological Society of America Bulletin, v. 121 , no. 3/4, p. 586-598. http://doi. org/10.1130/B26131.1

Duk-Rodkin, Alejandra, Barendregt, R.W., Froese, D.G., Weber, F.R., Enkin, Randy, Smith, I.R., Zazula, G.D., Waters, Pamela, and Klassen, Rudy, 2004, Timing and extent of Plio-Pleistocene glaciations in northwestern Canada and east-central Alaska, in Ehlers, J., and Gibbard, P.L., eds., Quaternary glaciations-Extent and chronology, Part IINorth America: New York, Elsevier, Developments in Quaternary Sciences, v. 2, part B, p. 313-345. http:// doi.org/10.1016/S1571-0866(04)80206-9

Duk-Rodkin, Alejandra, Weber, F.R., and Barendregt, R.W., 2002, Glacial limits map of upper Yukon River: Geological Survey of Canada Open-file 4275, 1 plate, scale 1:1,000,000. http://doi.org/10.4095/213393

Easton, N.A., Mackay, G.R., Young, P.B., Schnurr, Peter, and Yesner, D.R., 2011, Chindadn in Canada?, in Goebel, Ted, and Buvit, Ian, eds., From the Yenisei to the Yukon-Interpreting lithic assemblage variability in late Pleistocene/early Holocene Beringia: College Station, Texas A \& M University Press, p. 289-307.

Easton, N.A., Yesner, D.R., Hutchinson, Vance, Schnurr, Peter, and Baker, Christopher, 2009, Wisconsin-interstadial(?), terminal-Pleistocene, and early Holocene radiocarbon dates from the Little John site, southwest Yukon Territory, Canada: Current Research in the Pleistocene, v. 26, p. 47-50. 
Fernald, A.T., 1965, Glaciation in the Nabesna River area, upper Tanana River valley, Alaska, in U.S. Geological Survey Research 1965: U.S. Geological Survey Professional Paper 525-C, p. C120-C123. https:// pubs.er.usgs.gov/publication/pp525C

Ferrians, O.J., Jr., 1965, Permafrost map of Alaska: U.S. Geological Survey Miscellaneous Geologic Investigations Map 445, 1 sheet, scale 1:2,500,000. https:// pubs.er.usgs.gov/publication/i445

1988, Pingos in Alaska-A review, in Senneset, Karre, ed., Proceedings of the Fifth International Conference on Permafrost: Trondheim, Norway, Tapir Publishers, p. 734-739.

1989, Glacial Lake Atna, Copper River basin, Alaska, in Carter, L.D., Hamilton, T.D., and Galloway, J.P., eds., Late Cenozoic history of the interior basins of Alaska and the Yukon: U.S. Geological Survey Circular 1026, p. 85-88. https://pubs.er.usgs. gov/publication/cir1026

Ferrians, O.J., Jr., Kachadoorian, Reuben, and Greene, G.W., 1969, Permafrost and related engineering problems in Alaska: U.S. Geological Survey Professional Paper 678, 37 p. https://pubs.er.usgs.gov/ publication/pp678

Ferrians, O.J., Jr., Nichols, D.R., and Williams, J.R., 1983, Copper River basin, in Péwé, T.L., and Reger, R.D., eds., Guidebook to permafrost and Quaternary geology along the Richardson and Glenn highways between Fairbanks and Anchorage, Alaska: Alaska Division of Geological \& Geophysical Surveys Guidebook 1, p. 137-175. http://doi.org/10.14509/263

Ferrians, O.J., Jr., and Schmoll, H.R., 1957, Extensive proglacial lake of Wisconsin age in the Copper River basin, Alaska [abs.]: Geological Society of America Bulletin, v. 68, no. 12, part 2, p. 1,726.

Fitch, Gary, 2008, Foundation geology report, Tanana River Bridge \#505 [Project no. BR-OA2-1(0]: Alaska Department of Transportation and Public Facilities report, $415 \mathrm{p}$.

Foster, H.L., 1970, Reconnaissance geologic map of the Tanacross Quadrangle, Alaska: U.S. Geological Survey Miscellaneous Geologic Investigations Map I-593, 1 sheet, scale1:250,000. https://pubs.er.usgs. gov/publication/i593

Foster, H.L., and Holmes, G.W., 1965, A large transitional rock glacier in the Johnson River area, Alaska Range: U.S. Geological Survey Professional Paper 525-B, p. B112-B116. https://pubs.er.usgs.gov/ publication/pp525B
French, H.M., 2007, The periglacial environmentChichester, England: London, John Wiley \& Sons, Ltd., 458 p.

Freymueller, J.T., Woodward, Hilary, Cohen, S.C., Cross, Ryan, Elliott, Julie, Larsen, C.F., Hreinsdóttir, Sigrún, and Zweck, Chris, 2008, Active deformation processes in Alaska, based on 15 years of GPS measurements, in Freymueller, J.T., Haeussler, P.J., Wesson, R.L., and Ekström, Göran, eds., Active tectonics and seismic potential of Alaska: American Geophysical Union Geophysical Monograph 179, p. 1-42. http://doi.org/10.1029/179GM02

Froese, D.G., Smith, D.G., Westgate, J.A., Ager, T.A., Preece, S.J., Sandhu, A.S., Enkin, R.J., and Weber, F.R., 2003, Recurring middle Pleistocene outburst floods in east-central Alaska: Quaternary Research, v. 60, no. 1, p. 50-62. http://doi.org/10.1016/ S0033-5894(03)00090-5

Grahek, M.E., and Livingston, H.R., 1983, Centerline soils and materials sources, Mile Post 1346.7 to 1332.8, Alaska Highway, Robertson River to Yerrick Creek, Project No. F-062-2(14): Alaska Department of Transportation \& Public Facilities Engineering Geology \& Soils report, $121 \mathrm{p}$.

Griscom, Andrew, 1976, Aeromagnetic map and interpretation of the Tanacross Quadrangle, Alaska: U.S. Geologic Survey Miscellaneous Field Studies MF767A, 2 sheets, scale 250,000. http://www.dggs. alaska.gov/pubs/id/13298

Guthrie, R.D., 1968, Paleoecology of the large-mammal community in interior Alaska during the late Pleistocene: American Midland Naturalist, v. 79, no. 2, p. 346-363. http://doi.org/10.2307/2423182

1982, Mammals of the mammoth steppe as paleoenvironmental indicators, in Hopkins, D.M., Matthews, J.V., Jr., Schweger, C.E., and Young, S.B., eds., Paleoecology of Beringia: New York, Academic Press, p. 307-326.

1990, Frozen fauna of the mammoth steppe; The story of Blue Babe: Chicago, The University of Chicago Press, $323 \mathrm{p}$.

Hamilton, T.D., 1982, A late Pleistocene glacial chronology for the southern Brooks Range-Stratigraphic record and regional significance: Geological Society of America Bulletin, v. 93, no. 8, p. 700-716. http:// doi.org/10.1130/0016-7606(1982)93<700:ALPGC $\mathrm{F}>2.0 . \mathrm{CO} ; 2$

1994, Late Cenozoic glaciation of Alaska, in Plafker, George, and Berg, H.C., eds., The geology of Alaska: Geological Society of America, Geology of North America, v. G-1, p. 813-844. 
Hamilton, T.D., and Bischoff, J.L., 1984, Uranium-series dating of fossil bones from the Canyon Creek vertebrate locality in central Alaska, in Reed, K.M., and Bartsch- Winkler, Susan, eds., The United States Geological Survey in Alaska-Accomplishments during 1982: U.S. Geological Survey Circular 939, p. 26-29. http://dggs.alaska.gov/pubs/id/13425

Hamilton, T.D., and Goebel, Ted, 1999, Late Pleistocene peopling of Alaska, in Bonnichsen, Robson, and Turnmire, K.L., eds., Ice age people of North AmericaEnvironments, origins, and adaptations: Corvallis, Oregon State University Press, p 156-199.

Hamilton, T.D., and Thorson, R.M., 1983, The Cordilleran ice sheet in Alaska, in Porter, S.C., ed., Late-Quaternary environments of the United States, v. 1, The late Pleistocene: Minneapolis, University of Minnesota Press, p. 38-52.

Harington, C.R., 2011, Pleistocene vertebrates of the Yukon Territory: Quaternary Science Reviews, v. 30, no. 17-18, p. 2,341-2,354. http://doi.org/10.1016/j. quascirev.2011.05.020

Harp, E.L., Jibson, R.W., Kayen, R.E., Keefer, D.K., Sherrod, B.L., Carver, G.A., Collins, B.D., Moss, R.E.S., and Sitar, Nicolas, 2003, Landslides and liquefaction triggered by the M 7.9 Denali fault earthquake of 3 November 2002: GSA Today, v. 13, no. 8, p. 4-10. https://www.geosociety.org/gsatoday/science. htm\#2003

Hemenway, K.T., 1994, Scottie Creek Bridge replacement (bridge no. 501), Alaska Highway MP 1222-North (Project No. IM-OA1-1(9): Alaska Department of Transportation \& Public Facilities foundation report, $20 \mathrm{p}$.

Hemenway, K.T., and Weaver, Monte, 1983, Alaska Highway bridges, mile post 1332.8 to 1346.7 , Yerrick Creek to Robertson River [Project F-062-2(14)]: Alaska Department of Transportation \& Public Facilities foundation report, $42 \mathrm{p}$.

Henderson, F.M., 1966, Open channel flow: New York, The Macmillan Company, $522 \mathrm{p}$.

Hinzman, L.D., Viereck, L.A., Adams, P.C., Romanovsky, V.E., and Yoshikawa, Kenji, 2006, Climate and permafrost dynamics of the Alaska boreal forest, in Chapin, F.S., III, Oswood, M.W., Van Cleve, Keith, Viereck, L.A., and Verbyla, D.L., eds., Alaska's changing boreal forest: Oxford, Oxford University Press, p. 39-61.

Holmes, C.E., 2011, Technology of the eastern Beringian tradition as viewed from Swan Point, in Goebel, Ted, and Buvit, Ian, eds., From the Yenisei to the YukonInterpreting lithic assemblage variability in late Pleistocene/early Holocene Beringia: College Station, Texas A
\& M University Press, p. 179-191.

Holmes, G.W., 1965, Geologic reconnaissance along the Alaska Highway, Delta River to Tok Junction, Alaska: U.S. Geological Survey Bulletin, 1181-H, 19 p., 1 sheet, scale 1:125,000. https://pubs.er.usgs.gov/ publication/b1181H

Holmes, G.W., and Foster, H.L., 1968, Geology of the Johnson River area, Alaska: U.S. Geological Survey Bulletin 1249, 49 p., 1 sheet, scale 1:63,360. https:// pubs.er.usgs.gov/publication/b1249

Holmes, G.W., Hopkins, D.M., and Foster, H.L., 1968, Pingos in central Alaska: U.S. Geological Survey Bulletin 1241-H, 40 p. https://pubs.er.usgs.gov/publication/ b1241H

Holmes, G.W., and Péwé, T.L., 1965, Geologic map of the Mt. Hayes D-3 Quadrangle, Alaska: U.S. Geological Survey Geologic Quadrangle Map GQ-366, 1 sheet, scale 1:63,360. https://pubs.er.usgs.gov/publication/ gq366

Hopkins, D.M., Karlstrom, T.N.V., Black, R.F., Williams, J.R., Péwé, T.L., Fernald, A.T., and Muller, E.H., 1955, Permafrost and ground water in Alaska: U.S. Geological Survey Professional Paper 264 F, p. F113-F146. http://dggs.alaska.gov/pubs/id/3817

Hopkins, D.M., and Kidd, J.G., 1988, Thaw lake sediments and sedimentary environments, in Senneset, Karre, ed., Proceedings of the Fifth International Conference on Permafrost: Trondheim, Norway, Tapir Publishers, p. 790-795.

Hubbard, T.D., Braun, M.L., Westbrook, R.E., and Gallagher, P.E., 2011 a, High-resolution lidar data for infrastructure corridors, Mount Hayes Quadrangle, Alaska, in Hubbard, T.D., Koehler, R.D., and Combellick, R.A., eds., High-resolution lidar data for Alaska infrastructure corridors: Alaska Division of Geological \& Geophysical Surveys Raw Data File 2011-3A. http:// doi.org/10.14509/22723

2011b, High-resolution lidar data for infrastructure corridors, Tanacross Quadrangle, Alaska, in Hubbard, T.D., Koehler, R.D., and Combellick, R.A., eds., High-resolution lidar data for Alaska infrastructure corridors: Alaska Division of Geological \& Geophysical Surveys Raw Data File 2011-3B. http://doi. org/10.14509/22724

-2011c, High-resolution lidar data for infrastructure corridors, Nabesna Quadrangle, Alaska, in Hubbard, T.D., Koehler, R.D., and Combellick, R.A., eds., High-resolution lidar data for Alaska infrastructure corridors: Alaska Division of Geological \& Geophysical Surveys Raw Data File 2011-3C. http://doi. org/10.14509/22725 
Hubbard, T.D., Koehler, R.D., and Combellick, R.A., 2011d, High-resolution lidar data for Alaska infrastructure corridors: Alaska Division of Geological \& Geophysical Surveys Raw Data File 2011 3, 291 p. http://doi.org/10.14509/22722

Hubbard, T.D., and Reger, R.D., 2010a, Engineeringgeologic map of the Alaska Highway corridor, Robertson River to Tetlin Junction, Alaska: Alaska Division of Geological \& Geophysical Surveys Preliminary Interpretive Report 2009-6b, 4 sheets, scale 1:63,360. http://doi.org/10.14509/19742

2010b, Model for late Wisconsinan massive outburst flooding, Tok River valley, northeastern Alaska Range [abs]: Geological Society of America Abstracts with Programs, v. 42, no. 5, p. 310.

Hubbard, T,D., Reger, R.D., and Gallagher, P.E., 2011e, Using lidar to refine geologic mapping and interpretations in the upper Tanana River valley, central Alaska [abs.]: Geological Society of America Abstracts with Programs, v. 43, no. 5, p. 623.

2013, Engineering-geologic map, Alaska Highway corridor, Tetlin Junction to Canada border, Alaska: Alaska Division of Geological \& Geophysical Surveys Preliminary Interpretive Report 2012-1B, 2 sheets, scale 1:63,360. http://doi.org/10.14509/24624

Hughes, O.L., 1989, Quaternary chronology, Yukon and western District of Mackenzie, in Carter, L.D., Hamilton, T.D., and Galloway, J.P., eds., Late Cenozoic history of interior basins of Alaska and the Yukon: U.S. Geological Survey Circular 1026, p. 25-29. http:// dggs.alaska.gov/pubs/id/13412

Jorgenson, M.T., and Osterkamp, T.E., 2005, Response of boreal ecosystems to varying modes of permafrost degradation: Canadian Journal of Forestry Research, v. 35, no. 9, p. 2,100-2,111. http://doi.org/10.1139/ $\mathrm{x} 05-153$

Jorgenson, M.T., and Racine, C.H., 2001, Review of potential impacts of the proposed GVEA powerline on ecosystems on the Tanana Flats: Final report prepared for Alaska Division of Mining, Land, and Water by ABR, Inc., Fairbanks, 24 p.

Jorgenson, M.T., Racine, C.H., Walters, J.C., and Osterkamp, T.E., 2001, Permafrost degradation and ecological changes associated with a warming climate in central Alaska: Climatic Change, v. 48, p. 551-579. http://doi.org/10.1023/A:1005667424292

Jorgenson, Torre, Yoshikawa, Kenji, Romanovsky, Vladimir, Kanevskiy, Mikhail, Brown, Jerry, Shur, Yuri, Marchenko, Sergei, Grosse, Guido, and Jones, Ben, 2008, Map of permafrost characteristics in Alaska, in Kane, D.L., and Hinkel, K.M., eds., Proceedings of the
Ninth International Conference on Permafrost, Fairbanks, Alaska, University of Alaska Fairbanks, v. I, p. 121-122.

Kehew, A.E., 2006, Geology for engineers and environmental scientists-Upper Saddle River: New Jersey, Pearson Prentice Hall, 696 p.

Kelson,, K.I., Kang, K.-H., Page, W.D., Lee, C.-T., and Cluff, L.S., 2001, Representative styles of deformation along the Chelungpu fault for the 1999 Chi-Chi (Taiwan) earthquake-Geomorphic characteristics and responses of man-made structures: Seismological Society of America Bulletin, v. 91, no. 5, p. 930-952. http://doi.org/10.1785/0120000741

Koehler, R.D., 2011, Application of LiDAR to mapping geologic hazards along gas pipelines in Alaska [abs.]: Geological Society of American Abstracts with Programs, v. 43, no. 4, p. 83-84.

Koehler, R.D., and Carver, G.A., 2012, Active and potentially active faults along the Alaska Highway corridor, Tetlin Junction to the Canada border, Alaska: Alaska Division of Geological \& Geophysical Surveys Preliminary Interpretive Report 2012-2, 23 p. http://doi. org/10.14509/23923

Koehler, R.D., Farrell, R.-E., and Carver, G.A., 2010, Paleoseismic study of the Cathedral Rapids faultActive imbricate thrust faulting along the northern Alaska Range near Tok, Alaska [abs.]: EOS, Transactions of the American Geophysical Union, Fall meeting supplement, abstract T33A-2217.

Koehler, R.D., and Woods, R-E.F., 2013, Paleoseismic and lidar investigations along the Cathedral Rapids fault and Dot "T" Johnson faults, interior Alaska: Alaska Division of Geological \& Geophysical Surveys Report of Investigation 2013-4, 21 p. http://doi. org/10.14509/26761

Komar, P.D., 1983, Shapes of streamlined islands on Earth and Mars-Experiments and analyses of the minimumdrag form: Geology, v. 11, no. 11, p. 651-655. http:// doi.org/10.1130/0091-7613(1983)11<651:SOSIOE> 2.0.CO;2

Kreig, R.A., and Reger, R.D., 1982, Air-photo analysis and summary of landform soil properties along the route of the Trans-Alaska Pipeline System: Alaska Division of Geological \& Geophysical Surveys Geologic Report 66, 149 p. http://doi.org/10.14509/426

Lacelle, Denis, Lauriol, Bernard, Clark, I.D., Cardyn, Raphaelle, and Zdanowicz, Christian, 2007, Nature and origin of a Pleistocene massive ground-ice body exposed in the Chapman Lake moraine complex, central Yukon Territory, Canada: Quaternary Research, v. 68, no. 2, p. 249-260. http://doi.org/10.1016/j.yqres.2007.05.002 
Lachenbruch, A.H., 1962, Mechanics of thermal contraction cracks and ice-wedge polygons in permafrost: Geological Society of America Special Paper 70, 69 p. http://doi.org/10.1130/SPE70-p1

1968, Permafrost, in Fairbridge, R.W., ed., The encyclopedia of geomorphology: New York, Reinhold Publishing Corporation, p. 833-839.

Lea, P.D., 1990, Pleistocene periglacial eolian deposits in southwestern Alaska-Sedimentary facies and depositional processes: Journal of Sedimentary Petrology, v. 60, no. 4, p. 582-591. http:// doi.org/10.1306/212F91F1-2B24-11D7$8648000102 \mathrm{C} 1865 \mathrm{D}$

Lea, P.D., and Waythomas, C.F., 1990, Late Pleistocene eolian sand sheets in Alaska: Quaternary Research, v. 34, no. 3, p. 269-281. http://doi. org/10.1016/0033-5894(90)90040-R

Lerbekmo, J.F., 2008, The White River ash-Largest Holocene plinian tephra: Canadian Journal of Earth Sciences, v. 45, no. 6, p. 693-700. http://doi. org/10.1139/E08-023

Lindholm, G.F., Thomas, L.A., Davidson, D.T., Hardy, R.L., and Roy, C.J., 1959, Silts near Big Delta and Fairbanks, in Davidson, D.T., and Roy, C.J., eds., The geology and engineering characteristics of some Alaskan silts: Ames, Iowa, Iowa Engineering Experiment Station Bulletin 186, p. 33-70.

Lipovsky, P.S., Coates, Jim, Lewkowicz, A.G., and Trochim, Erin, 2006, Active-layer detachments following the summer 2004 forest fires near Dawson City, Yukon, in Edmond, D.S., Bradshaw, G.D., Lewis, L.L., and Weston, L.H., eds., Yukon exploration and geology, 2005: Yukon Geological Survey report, p. 175-194. http://data.geology.gov.yk.ca/Reference/ DownloadProduct/16885

Lobeck, A.K., 1939, Geomorphology: New York, McGraw-Hill Book Company, Inc., 781 p.

Mann, D.H., Fastie, C.L., Rowland, E.L., and Bigelow, N.H., 1995, Spruce succession, disturbance, and geomorphology on the Tanana River floodplain, Alaska: Ecoscience, v. 2, no. 2, p. 184-199. http://doi.org/10 $.1080 / 11956860.1995 .11682283$

Mann, D.H., Groves, Pamela, Kunz, M.L., Reanier, R.E, and Gaglioti, B.V., 2013, Ice-age mammals in arctic Alaska: Extinction, invasion, survival: Quaternary Science Reviews, v. 70, p. 91-108. http://doi. org/10.1016/j.quascirev.2013.03.015

Mason, O.K., and Begét, J.E., 1991, Late-Holocene flood history of the Tanana River, Alaska, U.S.A.:
Arctic and Alpine Research, v. 23, no. 4, p. 392-403. http://doi.org/10.2307/1551681

Matheus, Paul, Begét, James, Mason, Owen, and GelvinReymiller, Carol, 2003, Late Pliocene to late Pleistocene environments preserved at the Palisades site, central Yukon River, Alaska: Quaternary Research, v. 60, no. 1, p. 33-43. http://doi.org/10.1016/ S0033-5894(03)00091-7

Matmon, A., Briner, J.P., Carver, G.A., Bierman, P., and Finkel, R.C., 2010, Moraine chronosequence of the Donnelly Dome region, Alaska: Quaternary Research, v. 74, no. 1, p. 63-72. http://doi.org/10.1016/j. yqres.2010.04.007

McCalpin, J.P., 1996, Application of paleoseismic data to seismic hazard assessment and neotectonic research, in McCalpin, J.P., ed., Paleoseismology: New York, Academic Press, International Geophysics Series, v. 62, p. 439-493.

Meghraoui, M., Philip, H., Albarede, F., and Cisternas, A., 1988, Trench investigations through the trace of the 1980 El Asnam thrust fault-Evidence for paleoseismicity: Bulletin of the Seismological Society of America, v. 78, no. 2, p. 979-999.

Merriam-Webster, 2002, Merriam-Webster collegiate dictionary: Springfield, Massachusetts, MerriamWebster, Inc., 1,557 p.

Minsley, B.J., Abraham, J.D., Smith, B.D., Cannia, J.C., Voss, C.I., Jorgenson, M.T., Walvoord, M.A., Wylie, B.K., Anderson, Lesleigh, Ball, L.B., DeszczPan, Maryla, Wellman, T.P., and Ager, T.A., 2012, Airborne electromagnetic imaging of discontinuous permafrost: Geophysical Research Letters, v. 39, no. 2, 8 p. http://doi.org/10.1029/2011GL050079

Mitchell, J.M., Jr., 1956, Strong surface winds at Big Delta, Alaska-An example of orographic influence on local weather: Monthly Weather Review, v. 84, no. 1, p. 15-24. http://doi. org/10.1175/1520-0493(1956)084<0015:SSWABD $>2.0 . \mathrm{CO} ; 2$

Moffit, F.H., 1954, Geology of the eastern part of the Alaska Range and adjacent areas: U.S. Geological Survey Bulletin 989-D, p. D65-D218. https://pubs. er.usgs.gov/publication/b989D

Muhs, D.R., Ager, T.A., and Begét, J.E., 2001, Vegetation and paleoclimate of the last interglacial period, central Alaska: Quaternary Science Reviews, v. 20, no. 1, p. 41-61. http://doi.org/10.1016/ S0277-3791(00)00132-3 
Muhs, D.R., Ager, T.A., Been, J.M., Rosenbaum, J.G., and Reynolds, R.L., 2000, An evaluation of methods for identifying and interpreting buried soils in late Quaternary loess in Alaska, in Kelley, K.D., and Gough, L.P., eds., Geologic studies in Alaska by the U.S. Geological Survey, 1998: U.S. Geological Survey Professional Paper 1615, p. 127-146. http://pubs.usgs. gov/pp/p1615/

Muhs, D.R., Ager, T.A., Bettis, E.A., III, McGeehin, John, Been, J.M., Begét, J.E., Pavich, M.J., Stafford, T.W., Jr., and Stevens, D.S.P., 2003, Stratigraphy and palaeoclimatic significance of late Quaternary loess-palaeosol sequences of the late Interglacial-Glacial cycle in central Alaska: Quaternary Science Reviews, v. 22, no. 18-19, p. 1,947-1,986. http://doi.org/10.1016/ S0277-3791(03)00167-7

Muhs, D.R., and Budahn, J.R., 2006, Geochemical evidence for the origin of late Quaternary loess in central Alaska: Canadian Journal of Earth Sciences, v. 43, no. 3, p. 323-337. http://doi.org/10.1139/e05-115

Muller, S.W., 1947, Permafrost or permanently frozen ground and related engineering problems: Ann Arbor, Michigan, J.W. Edwards, Inc., 231 p.

Murton, J.B., 1996, Thermokarst-lake-basin sediments, Tuktoyaktuk coastlands, western arctic Canada: Sedimentology, v. 43, no. 4, p. 737-760. http://doi. org/10.1111/j.1365-3091.1996.tb02023.x

Murton, J.B., Worsley, P., and Gozdzik, J.S., 2000, Sand veins and wedges in cold aeolian environments: Quaternary Science Reviews, v. 19, no. 9, p. 899-922. http://doi.org/10.1016/S0277-3791(99)00045-1

Nelson, A.R., Johnson, S.Y., Kelsey, H.M., Wells, R.E., Sherrod, B.L., Pezzopane, S.K., Bradley, Lee-Ann, Koehler, R.D., and Bucknam, R.C., 2003, Late Holocene earthquakes on the Toe Jam Hill fault, Seattle fault zone, Bainbridge Island, Washington: Geological Society of America Bulletin, v. 115, no. 11, p. 1,3881,403. http://doi.org/10.1130/B25262.1

Nelson, G.L., 1995, Overview of environmental and hydrologic conditions near Big Delta, Alaska: U.S. Geological Survey Open-File Report 95-180, 11 p. https://pubs.er.usgs.gov/publication/ofr95180

Nelson, R.E., Carter, L.D., and Robinson, S.W., 1988, Anomalous radiocarbon ages from a Holocene detrital organiclens in Alaska and their implications for radiocarbon dating and paleoenvironmental reconstruction in the Arctic: Quaternary Research, v. 29, no. 1, p. 66-71. http://doi.org/10.1016/0033-5894(88)90072-5

O'Connor, J.E., 1993, Hydrology, hydraulics, and geomorphology of the Bonneville flood: Geological Society of America Special Paper 274, p. 1-84. http://doi.
org/10.1130/SPE274-p1

O'Connor, J.E., and Webb, R.H., 1988, Hydraulic modeling for paleoflood analysis, in Baker, V.R., Kochel, R.C., and Patton, P.C., eds., Flood geomorphology: New York, John Wiley \& Sons, p. 403-418.

Orth, D.J., 1971, Dictionary of Alaska place names: U.S. Geological Survey Professional Paper 567, 1,084 p. https://pubs.er.usgs.gov/publication/pp567

Osterkamp, T.E., and Romanovsky, V.E., 1999, Evidence for warming and thawing of discontinuous permafrost in Alaska: Permafrost and Periglacial Processes, v. 10, no. 1, p. 17-37. http://doi.org/10.1002/ (SICI) 1099-1530(199901/03)10:1<17::AIDPPP303>3.0.CO;2-4

Osterkamp, T.E., Viereck, L.A., Shur, Y., Jorgenson, M.T., Racine, C., Doyle, A., and Boone, R.D., 2000, Observations of thermokarst and its impact on boreal forests in Alaska, U.S.A.: Arctic, Antarctic, and Alpine Research, v. 32, no. 3, p. 303-315.

Panda, S.K., Prakash, Anupma, Jorgenson, M.T., and Solie, D.N., 2012, Near-surface permafrost distribution mapping using logistic regression and remote sensing in interior Alaska: GIScience and Remote Sensing, v. 49, no. 3, p. 346-363.

Panda, S.K., Prakash, Anupma, Solie, D.N., Romanovsky, V.E., and Jorgenson, M.T., 2010, Remote sensing and field-based mapping of permafrost distribution along the Alaska Highway corridor, interior Alaska: Permafrost and Periglacial Processes, v. 21, no. 3, p. 271-281. http://doi.org/10.1002/ppp.686

Panda, S.K., Prakash, Anupma, and Solie, D.N., 2008, Remote sensing-based study of vegetation distribution and its relation to permafrost in and around George Lake area, central Alaska, in Kane, D.L., and Hinkel, K.M., eds., Proceedings of the Ninth International Conference on Permafrost, Fairbanks, Alaska, University of Alaska Fairbanks, v. II, p. 1,357-1,362.

Pastick, N.J., Jorgenson, M.T., Wylie, B.K., Minsley, B.J., Ji, Lei, Walvoord, M.A., Smith, B.D., Abraham, J.D., and Rose, J.R., 2013, Extending airborne electromagnetic surveys for regional active layer and permafrost mapping with remote sensing and ancillary data, Yukon Flats ecoregion, central Alaska: Permafrost and Periglacial Processes, v. 24, no. 3, p. 184-199. http:// doi.org/10.1002/ppp.1775

Péwé, T.L., 1951, An observation of wind-blown silt: Journal of Geology, v. 59, no. 4, p. 399-401.

1954, Effect of permafrost on cultivated fields, Fairbanks, Alaska: U.S. Geological Survey Bulletin, 989 F, p. F315-F351. https://pubs.er.usgs.gov/ publication/b989F 
1955, Origin of the upland silt near Fairbanks, Alaska: Geological Society of America Bulletin, v. 66, p. 699-724. http://doi. org/10.1130/0016-7606(1955)66[699:OOTUSN]2 .0.CO;2

1959, Sand-wedge polygons (tessellations) in the McMurdo Sound region, Antarctica-A progress report: American Journal of Science, v. 257, no. 8, p. 545-552. http://doi.org/10.2475/ajs.257.8.545

-1965, Middle Tanana River valley, in Péwé, T.L., Ferrians, O.J., Jr., and Karlstrom, T.N.V., eds., Guidebook for Field Conference F, central and south-central Alaska, International Association for Quaternary Research, 7th Congress, Fairbanks 1965: Lincoln, Nebraska Academy of Science, p. 36-54 (reprinted 1977, College, Alaska Division of Geological \& Geophysical Surveys). http://doi.org/10.14509/667

1968, Loess deposits of Alaska: 23rd International Geologic Congress, Prague 1968, v. 8, p. 297-309.

1970, Permafrost and vegetation in floodplains of subarctic rivers (Alaska), a summary, in Ecology of the subarctic regions-Proceedings of the Helsinki symposium: UNESCO, p. 141-142.

Péwé, T.L., 1975a, Quaternary geology of Alaska: U.S. Geological Survey Professional Paper 835, 145 p. https://pubs.er.usgs.gov/publication/pp835

-1975b, Quaternary stratigraphic nomenclature in unglaciated central Alaska: U.S. Geological Survey Professional Paper 862, 32 p. https://pubs.er.usgs. gov/publication/pp862

1982, Geologic hazards of the Fairbanks area, Alaska: Alaska Division of Geological \& Geophysical Surveys Special Report 15, 119 p. http://doi. org/10.14509/2614

Péwé, T.L., Berger, G.W., Westgate, J.A., Brown, P.M., and Leavitt, S.W., 1997, Eva Interglaciation forest bed, unglaciated east-central Alaska-Global warming 125,000 years ago: Geological Society of America Special Paper 319, p. 1-55. http://doi. org/10.1130/0-8137-2319-1.1

Péwé, T.L., Church, R.E., and Andresen, M.J., 1969, Origin and paleoclimatic significance of large-scale patterned ground in the Donnelly Dome area, Alaska: Geological Society of America Special Paper 103, p. 1-84. http://doi.org/10.1130/SPE103-p1

Péwé, T.L., and Holmes, G.W., 1964, Geology of the Mt. Hayes D-4 Quadrangle, Alaska: U.S. Geological Survey Miscellaneous Geologic Investigations Map I-394, 2 sheets, scale 1:63,360. https://pubs.er.usgs. gov/publication/i394

Péwé, T.L., and Reger, R.D., 1983a, Delta River area, Alaska Range, in Péwé, T.L., and Reger, R.D., eds., Guidebook to permafrost and Quaternary geology along the Richardson and Glenn highways between Fairbanks and Anchorage, Alaska: Alaska Division of Geological \& Geophysical Surveys Guidebook 1, p. 47-135. http://doi.org/10.14509/263

-1983b, Middle Tanana River valley, in Péwé, T.L., and Reger, R.D., eds., Guidebook to permafrost and Quaternary geology along the Richardson and Glenn highways between Fairbanks and Anchorage, Alaska: Alaska Division of Geological \& Geophysical Surveys Guidebook 1, p. 5-45. http://doi. org/10.14509/263

Péwé, T.L., Wahrhaftig, C.A., and Weber, F.R, 1966, Geologic map of the Fairbanks Quadrangle, Alaska: U.S. Geological Survey Miscellaneous Geological Investigations Map I-455, 5 p., 1 sheet, scale 1:250,000. https://pubs.er.usgs.gov/publication/i455

Péwé, T.L., Westgate, J.A., Preece, S.J., Brown, P.M., and Leavitt, S.W., 2009, Late Pliocene Dawson cut forest bed and new tephrochronological findings in the Gold Hill loess, east-central Alaska: Geological Society of America Bulletin, v. 121, no. 1-2, p. 294 320. http://doi.org/10.1130/B26323.1

Plafker, George, Gilpin, L.M., and Lahr, J.C., 1994, Neotectonic map of Alaska, in Plafker, George, and Berg, H.C., eds., The geology of Alaska: Geological Society of America, the Geology of North America, v. G-1, plate 12, scale 1:2,500,000.

Post, Austin, and Mayo, L.R., 1971, Glacier dammed lakes and outburst floods in Alaska: U.S. Geological Survey Hydrologic Investigations Atlas HA-455, 10 p., scale 1:1,000,000, 3 sheets. http://pubs.usgs.gov/ ha/ $455 /$

Potter, B.A., 2005, Site structure and organization in central Alaska-Archaeological investigations at Gerstle River: Fairbanks, University of Alaska Fairbanks Ph.D. dissertation, 936 p. https://www.uaf.edu/ anthro/gradresearch-files/Potter_Ben.pdf

Potter, B.A., Gilbert, P.J., Holmes, C.E., and Crass, B.A., 2011a, The Mead site-A late Pleistocene/Holocene stratified site in central Alaska: Current Research in the Pleistocene, v. 28, p. 73-75.

Potter, B.A., Irish, J.D., Reuther, J.D., Gelvin-Reymiller, Carol, and Holliday, V.T., 2011b, A terminal Pleistocene child cremation and residential structure from eastern Beringia: Science, v. 331, no. 6020, p. 1,0581,061. http://doi.org/10.1126/science.1201581 
Potter, B.A., Irish, J.D., Reuther, J.D., and McKinney, H.J., 2014, New insights into eastern Beringian mortuary behavior-A terminal Pleistocene double infant burial at Upward Sun River: Proceedings of the National Academy of Sciences, v. 111, no. 48, p. 17,060-17,065. http://doi.org/10.1073/ pnas. 1413131111

Potter, B.A., Reuther, J.D., Bowers, P.M., and GelvinReymiller, Carol, 2008, Little Delta dune site-A late-Pleistocene multicomponent site in central Alaska: Current Research in the Pleistocene, v. 25, p. 132-135.

Preece, S.J., Pearce, N.J.G., Westgate, J.A., Froese, D.G., Jensen, B.J.L., and Perkins, W.T., 2011, Old Crow tephra across eastern Beringia-A single cataclysmic eruption at the close of Marine Isotope Stage 6: Quaternary Science Reviews, v. 30, no. 17-18, p. 2,069-2,090. http://doi.org/10.1016/j. quascirev.2010.04.020

Preece, S.J., Westgate, J.A., Stemper, B.A., and Péwé, T.L., 1999, Tephrochronology of late Cenozoic loess at Fairbanks, central Alaska: Geological Society of America Bulletin, v. 111, no. 1, p. 71-90. http://doi. org/10.1130/0016-7606(1999)111<0071:TOLCLA $>2.3 . \mathrm{CO} ; 2$

Racine, C.H., and Walters, J.C., 1994, Groundwater-discharge fens in the Tanana lowlands, interior Alaska, U.S.A.: Arctic and Alpine Research, v. 26, no. 4, p. 418-426.

Railsback, L.B., Gibbard, P.L., Head, M.J., Voarintsoa, N.R.G., and Toucanne, S., 2015, An optimized scheme of lettered marine isotope substages for the last 1.0 million years, and the climatostratigraphic nature of isotope stages and substages: Quaternary Science Reviews, v. 111, p. 94-106. http://doi.org/10.1016/j. quascirev.2015.01.012

Reger, R.D., and Hubbard, T.D., 2009, Evidence for late Wisconsinan outburst floods in the Tok-Tanacross basin, upper Tanana River valley, east-central Alaska [abs.]: Geological Society of America Abstracts with Programs, v. 41, no. 7, p. 637.

2010, Reconnaissance interpretation of 19781983 permafrost, Alaska Highway corridor, Robertson River to Tetlin Junction, Alaska: Alaska Division of Geological \& Geophysical Surveys Preliminary Interpretive Report 2009-6c, 13 p., 4 sheets, scale 1:63,360. http://doi.org/10.14509/19743

Reger, R.D., Hubbard, T.D., and Carver, G.A., 2011, Surficial geology of the Alaska Highway corridor, Robertson River to Tetlin Junction, Alaska: Alaska Division of Geological \& Geophysical Surveys Preliminary
Interpretive Report 2009-6a, 53 p., 4 sheets, scale 1:63,360. http://doi.org/10.14509/19741

Reger, R.D., Hubbard, T.D., and Gallagher, P.E., 2012a, Surficial geology of the Alaska Highway corridor, Tetlin Junction to Canada border, Alaska: Alaska Division of Geological \& Geophysical Surveys Preliminary Interpretive Report 2012-1A, 27 p., 2 sheets, scale 1:63,360. http://doi.org/10.14509/23443

2012b, Reconnaissance interpretation of 19781983 permafrost, Alaska Highway corridor, Tetlin Junction to Canada border, Alaska: Alaska Division of Geological \& Geophysical Surveys Preliminary Interpretive Report 2012-1C, 27 p., 2 sheets, scale 1:63,360. http://doi.org/10.14509/23444

Reger, R.D., and Péwé, T.L., 2002, Geologic map of the Big Delta A-4 Quadrangle, Alaska: Alaska Division of Geological \& Geophysical Surveys Report of Investigations 2002-2, 1 sheet, scale 1:63,360. http://doi. org/10.14509/2869

Reger, R.D., and Solie, D.N., 2008a, Reconnaissance interpretation of permafrost, Alaska Highway corridor, Delta Junction to Dot Lake, Alaska: Alaska Division of Geological \& Geophysical Surveys Preliminary Interpretive Report 2008-3c, 10 p., 2 sheets, scale 1:63,360. http://doi.org/10.14509/17621

-2008b, Engineering geologic map, Alaska Highway corridor, Delta Junction to Dot Lake, Alaska: Alaska Division of Geological \& Geophysical Surveys Preliminary Interpretive Report 2008-3b, 2 sheets, scale 1:63,360. http://doi.org/10.14509/17981

Reger, R.D., Stevens, D.S.P., and Solie, D.N., 2008a, Surficial geology of the Alaska Highway corridor, Delta Junction to Dot Lake, Alaska: Alaska Division of Geological \& Geophysical Surveys Preliminary Interpretive Report 2008-3a, 48 p., 2 sheets, scale 1:63,360. http://doi.org/10.14509/17961

2008b, Evidence of multiple outburst floods, upper Tanana River valley, east-central Alaska [abs.]: Geological Society of America Abstracts with Programs, v. 40, no. 1, p. 36.

Reimer, P.J., Bard, Edouard, Bayliss, Alex, Beck, J.W., Blackwell, P.G., Ramsey, C.B., Buck, C.E., Cheng, Hai, Edwards, R.L., Friedrich, Michael, Grootes, P.M., Guilderson, T.P., Haflidason, Haflidi, Hajdas, Irka, Hatte, Christine, Heaton, T.J., Hoffmann, D.L., Hogg, A.G., Hughen, K.A., Kaiser, K.F., Kromer, Bernd, Manning, S.W., Niu, Mu, Reimer, R.W., Richards, D.A., Scott, E.M., Southon, J.R., Staff, R.A., Turney, C.S.M., and van der Plicht, Johannes, 2013, IntCal13 and Marine13 radiocarbon age calibration curves $0-50,000$ years cal BP: Radiocarbon, v. 55, no. 4, p. 1,869-1,887. http:// doi.org/10.2458/azu_js_rc.55.16947 
Richter, D.H., 1976, Geologic map of the Nabesna Quadrangle, Alaska: U.S. Geological Survey Miscellaneous Investigations Map I-932, 1 sheet, scale 1:250,000. https://pubs.er.usgs.gov/publication/i932 Richter, D.H., Preece, S.J., McGimsey, R.G., and Westgate, J.A., 1995, Mount Churchill, Alaska-Source of the late Holocene White River Ash: Canadian Journal of Earth Sciences, v. 32, p. 741-748. http:// doi.org/10.1139/e95-063

Ridgway, K.D., Trop, J.M., Nokleberg, W.J., Davidson, C.M., and Eastham, K.R., 2002, Mesozoic and Cenozoic tectonics of the eastern and central Alaska Range-Progressive basin development and deformation in a suture zone: Geological Society of America Bulletin, v. 114, no. 12, p. 1,480-1,504. http://doi. org/10.1130/0016-7606(2002)114<1480:MACTO $\mathrm{T}>2.0 . \mathrm{CO} ; 2$

Robinson, S.D., 2001, Extending the late Holocene White River Ash distribution, northwestern Canada: Arctic, v. 54, no. 2, p. 157-161. http://doi. org/10.14430/arctic775

Schaefer, J.R.G., 2002, Stratigraphy, major oxide geochemistry, and ${ }^{40} \mathrm{Ar} /{ }^{39} \mathrm{Ar}$ geochronology of a tephra section near Tok, Alaska: Fairbanks, University of Alaska Fairbanks M.S. thesis, 62 p.

Schmoll, H.R., 1984, Late Pleistocene morainal and glaciolacustrine geology in the upper Copper RiverMentasta Pass area, Alaska [abs.]: Geological Society of America Abstracts with Programs, v. 16, no. 6, p. 330.

Scurfield, G., 1973, Reaction wood-Its structure and function: Science, v. 179 , no. 4,074, p. 647-655. http://doi.org/10.1126/science.179.4074.647

Sicard, K.R., Naibert, T.J., Hubbard, T.D., Twelker, Evan, Wypych, Alicja, Werdon, M.B., Willingham, A.L., Gillis, R.J., Lande,L.L., and Newberry, R.J., 2017, Geologic map of the Tok River area, Tanacross A-5 and A-6 quadrangles, eastern Alaska Range, Alaska: Alaska Division of Geological \& Geophysical Surveys Preliminary Interpretive Report 2017-3, 9 p., 1 sheet, scale 1:63,360.

Slemmons, D.B., and Depolo, C.M., 1986, Evaluation of active faulting and associated hazards, in Studies in geophysics-Active tectonics: Washington, D.C., National Academies Press, p. 45-62. http://doi. org/10.17226/624

Sloan, C.E., Zenone, Chester, and Mayo, L.R., 1976, Icings along the trans-Alaska pipeline route: U.S. Geological Survey Professional Paper 979, 31 p. https://pubs.er.usgs.gov/publication/pp979
Smith, C.A.S., Tarnocai, Charles, and Hughes, O.L., 1986, Pedological investigations of Pleistocene glacial drift surfaces in the central Yukon: Géographie Physique et Quaternaire, v. 40, no. 1, p. 29-37. http:// doi.org/10.7202/032620ar

Smith, G.A., 1986, Coarse-grained nonmarine volcaniclastic sediment-Terminology and depositional process: Geological Society of America Bulletin, v. 97, no. 1, p. 1-10. http://doi.org/10.1130/00167606(1986)97<1:CNVSTA > 2.0.CO;2

Solie, D.N., and Burns, L.E., 2006, Geology, geophysics, and geohazards along the Alaska Highway corridor, a project of the Alaska Division of Geological \& Geophysical Surveys (poster): Yukon Geoscience Annual Convention, Whitehorse, November, 2006: Alaska Division of Geological \& Geophysical Surveys, 1 sheet. http://doi.org/10.14509/21842

Solie, D.N., and Burns, L.E., 2007, Alaska Highway corridor geology and geophysics: Alaska GeoSurvey News, v. 10 , no. 1, p. 1-4. http://doi. org/10.14509/15756

Stewart, A.K., Heinrich, C.E., and Hubbard, T.D., 2017, Dendrogeomorphic evidence of frequent mass movement using reaction wood in black spruce, Alaska Highway milepost 1267, Northway Junction, Alaska: Alaska Division of Geological \& Geophysical Surveys Report of Investigations 2017-7, 18 p. http:// doi.org/10.14509/29734

Sturm, Matthew, Begét, J.E., and Benson, C.S., 1987, Observations of jökulhlaups from ice-dammed Strandline Lake, Alaska-Implications for paleohydrology, in Mayer, L., and Nash, D., eds., Catastrophic flooding: Boston, Allen and Unwin, p. 79-94.

Sturm, Matthew, and Benson, C.S., 1985, A history of jökulhlaups from Strandline Lake, Alaska, U.S.A.: Journal of Glaciology, v. 31, no. 109, p. 272-280. https://doi.org/10.3198/1985JoG31-109-272-280

1989, Jökulhlaups from Strandline Lake, Alaska, with special attention to the 1982 event: Alaska Division of Geological \& Geophysical Surveys Report of Investigations 88 10, 19 p. http://doi. org/10.14509/2458

Tarnocai, Charles, 1989, Paleosols of northwestern Canada, in Carter, L.D., Hamilton, T.D., and Galloway, J.P., eds., Late Cenozoic history of the interior basins of Alaska and Yukon: U.S. Geological Survey Circular 1026, p. 39-44. https://pubs.er.usgs.gov/ publication/cir1026 
Tarnocai, Charles, and Schweger, C.E., 1991, Late Tertiary and early Pleistocene paleosols in northwestern Canada: Arctic, v. 44, no. 1, p. 1-11. http://doi. org/10.14430/arctic1512

Tarnocai, Charles, Smith, S, and Hughes, O.L., 1985, Soil development on Quaternary deposits of various ages in the central Yukon Territory: Geological Survey of Canada Paper 85-1A, Current Research, Part A, p. 229-238. http://doi.org/10.4095/120018

Tempelman-Kluit, Dirk, 1980, Evolution of physiography and drainage in southern Yukon: Canadian Journal of Earth Sciences, v. 17, no. 9, p. 1,189-1,203. http://doi.org/10.1139/e80-125

Ten Brink, N.W., and Waythomas, C.F., 1985, Late Wisconsin glacial chronology of the north-central Alaska Range-A regional synthesis and its implicaitons for early human settlements, in Swanson, W., ed., North Alaska Range early man project: National Geographic Society Research Reports, v. 19, p. 15-32.

Thorson, R.M., 1986, Late Cenozoic glaciation of the northern Nenana Valley, in Hamilton, T.D., Reed, K.M., and Thorson, R.M., eds., Glaciation in Alaska, the geologic record: Anchorage, Alaska Geological Society, p. 99-121.

1989, Late Quaternary paleofloods along the Porcupine River, Alaska-Implications for regional correlation, in Carter, L.D., Hamilton, T.D., and Galloway, J.P., eds., Late Cenozoic history of the interior basins of Alaska and the Yukon: U.S. Geological Survey Circular 1026, p. 51-54. https://pubs.er.usgs. gov/publication/cir1026

Thorson, R.M., and Bender, Gary, 1985, Eolian deflation by ancient katabatic winds-A late Quaternary example from the north Alaska Range: Geological Society of America Bulletin, v. 96, no. 6, p. 702-709. http:// doi.org/10.1130/0016-7606(1985)96<702:EDBAK W>2.0.CO;2

Thorson, R.M., and Dixon, J.E., Jr., 1983, Alluvial history of the Porcupine River, Alaska-Role of glacial-lake overflow from northwest Canada: Geological Society of America Bulletin, v. 94, no. 5, p. 576-589. http:// doi.org/10.1130/0016-7606(1983)94<576:AHOTP $\mathrm{R}>2.0 . \mathrm{CO} ; 2$

Tuck, Ralph, 1940, Origin of the muck-silt deposits at Fairbanks, Alaska: Geological Society of America Bulletin, v. 51, no. 9, p. 1,295-1,310. http://doi. org/10.1130/GSAB-51-1295

Tweed, F.S., and Russell, A.J., 1999, Controls on the formation and sudden drainage of glacier-impounded
lakes-Implications for jökulhlaup characteristics: Progress in Physical Geography, v. 23, no. 1, p. 79-110. http://doi.org/10.1177/030913339902300104

UNAVCO, 2008, Open topography-A portal to high resolution topography data and tools, http:// opentopo.sdsc.edu/datasetMetadata? otCollectionI D=OT.102009.32607.1, flown July 29-August 3, 2008, last accessed December 19, 2016.

Viereck, L.A., 1970, Forest succession and soil development adjacent to the Chena River in interior Alaska: Arctic and Alpine Research, v. 2, no. 1, p. 1-26.

Viereck, L.A., and Little, E.L., Jr., 1972, Alaska trees and shrubs: Washington, D.C., U.S. Forest Service Agricultural Handbook 410, 265 p.

Wahrhaftig, C.A., and Black, R.F., 1958, Quaternary geology of the Nenana River valley and adjacent parts of the Alaska Range, in Quaternary and engineering geology in the central part of the Alaska Range: U.S. Geological Survey Professional Paper 293A, p 1-68. https://pubs.er.usgs.gov/publication/pp293AB

1965, Physiographic divisions of Alaska: U.S. Geological Survey Professional Paper 482, 52 p., 6 sheets, various scales. https://pubs.er.usgs.gov/ publication/pp 482

Wallace, R.E., 1948, Cave-in lakes in the Nabesna, Chisana, and Tanana river valleys, eastern Alaska: Journal of Geology, v. 56, no. 3, p. 171-181. http://www. journals.uchicago.edu/doi/abs/10.1086/625498

Walsh, T.J., Combellick, R.A., and Black, G.L., 1995, Liquefaction features from a subduction zone earthquake-Preserved examples from the 1964 Alaska earthquake: Washington Division of Geology and Earth Resources Report of Investigations 32, 80 p. http://file.dnr.wa.gov/publications/ ger_ri32_liquifaction_examp_1964_alaska_eq.pdf

Ward, B.C., Bond, J.D., and Gosse, J.C., 2007, Evidence for a 55-50 ka (early Wisconsin) glaciation of the Cordilleran ice sheet, Yukon Territory, Canada: Quaternary Research, v. 68, no. 1, p. 141-150. http://dx.doi.org/10.1016/j.yqres.2007.04.002

Washburn, A.L., 1980, Geocryology-A survey of periglacial processes and environments: New York, John Wiley \& Sons, 406 p.

Weber, F.R., 1971, Preliminary engineering geologic maps of the proposed trans-Alaska pipeline route, Fairbanks and Big Delta quadrangles: U.S. Geological Survey Open File Report 71-317, 2 sheets, scale 1:125,000. https://pubs.er.usgs.gov/publication/ ofr71317 
1986, Glacial geology of the Yukon-Tanana Upland, in Hamilton, T.D., Reed, K.M., and Thorson, R.M., eds., Glaciation in Alaska-The geologic record: Anchorage, Alaska Geological Society, p. 79-98.

Weber, F.R., Hamilton, T.D., Hopkins, D.M., Repenning, C.A., and Haas, Herbert, 1981, Canyon Creek-A late Pleistocene vertebrate locality in interior Alaska: Quaternary Research, v. 16, no. 2, p. 167180. http://doi.org/10.1016/0033-5894(81)90043-0

Weber, F.R., and Péwé, T.L., 1961, Engineering geology problems in the Yukon-Koyukuk lowland, Alaska, in Short Papers in the Geologic and Hydrologic Sciences 1961: U.S. Geological Survey Professional Paper 424-D, p. 371-373. https://pubs.er.usgs.gov/ publication/pp 424D

1970, Surficial and engineering geology of the central part of the Yukon-Koyukuk lowland, Alaska: U.S. Geological Survey Miscellaneous Geologic Investigations Map I 590, 2 sheets, scale 1:125,000. http://www.dggs.alaska.gov/pubs/id/13626

Westgate, J.A., Preece, S.J., Froese, D.G., Pearce, N.J.G., Roberts, R.G., Demuro, M., Hart, W.K., and Perkins, W., 2008, Changing ideas on the identity and stratigraphic significance of the Sheep Creek tephra beds in Alaska and the Yukon Territory, northwestern North America: Quaternary International, v. 178, no 1, p. 183-209. http://doi.org/10.1016/j. quaint.2007.03.009

Westgate, J.A., Preece, S.J., Froese, D.G., Walter, R.C., Sandhu, A.S., and Schweger, C.E., 2001, Dating early and middle (Reid) Pleistocene glaciations in central Yukon by tephrochronology: Quaternary Research, v. 56, no. 3, p. 335-348. http://dx.doi.org/10.1006/ qres.2001.2274

Wiedmer, Michael, Montgomery, D.R., Gillespie, A.R., and Greenberg, Harvey, 2010, Late Quaternary megafloods from Glacial Lake Atna, southcentral Alaska, U.S.A., Quaternary Research, v. 73, no. 3, p. 413424. http://dx.doi.org/10.1016/j.yqres.2010.02.005

Wilcox, D.E., 1980, Geohydrology of the DeltaClearwater area, Alaska: U.S. Geological Survey
Water-Resources Investigations 80-92, 26 p. http:// www.dggs.alaska.gov/pubs/id/22983

Williams, J.R., 1970, Ground water in the permafrost regions of Alaska: U.S. Geological Survey Professional Paper 696, 83 p. https://pubs.er.usgs.gov/ publication/pp696

1989, A working glacial chronology for the western Copper River basin, Alaska, in Carter, L.D., Hamilton, T.D., and Galloway, J.P., eds., Late Cenozoic history of the interior basins of Alaska and the Yukon: U.S. Geological Survey Circular 1026, p. 81-84. https://pubs.er.usgs.gov/publication/cir1026

Wolfe, S.A., Stevens, C.W., Gaandrse, Adrian, and Oldenborger, G.A., 2014, Lithalsa distribution, morphology and landscape associations in the Great Slave Lowland, Northwest Territories, Canada: Geomorphology, v. 204, p. 302-313. http://doi. org/10.1016/j.geomorph.2013.08.014

Yardley, D.H., 1951, Frost-thrusting in the Northwest Territories: Journal of Geology, v. 59, no. 1, p. 65-69. Yeend, W.E., 1996, Gold placers of the historical Fortymile River region, Alaska: U.S. Geological Survey Bulletin 2125, 75 p., 1 sheet, scale 1:63,360. https:// pubs.er.usgs.gov/publication/b2125

Young, N.E., Briner, J.P., and Kaufman, D.S., 2009, Late Pleistocene and Holocene glaciation of the Fish Lake valley, northeastern Alaska Range, Alaska: Journal of Quaternary Science, v. 24, no. 7, p. 677-689. http://doi.org/10.1002/jqs.1279

Young, N.E., Briner, J.P., Kaufman, D.S., and Finkel, R.C., 2007, 10Be ages from northern Alaska Range moraines help constrain the timing of the penultimate glaciation in eastern Beringia [poster]: American Geophysical Union meeting, December 10-14, 2007, San Francisco, CA.

Young, S.B., 1982, The vegetation of land-bridge Beringia, in Hopkins, D.M., Matthews, J.V., Jr., Schweger, C.E., and Young, S.B., eds., Paleoecology of Beringia: New York, Academic Press, p. 179-191. http://doi. org/10.1016/B978-0-12-355860-2.50019-3 


\section{Appendix A: Surficial Geology DESCRIPTION OF SURFICIAL-GEOLOGIC MAP UNITS}

\section{INTRODUCTION}

This map shows the distribution of unconsolidated deposits and undifferentiated bedrock exposed at the surface along the Alaska Highway corridor from southern Big Delta Quadrangle to the eastern edge of the Nabesna Quadrangle at the Canada border. Units were mapped by interpreting false-color infrared 1:65,000-scale aerial photographs taken in July 1978, August 1980, August 1981, and July 1983, and verified by field checking in 2006-2010.

Map units are identified by the symbols described below. Symbols shown in parentheses, such as (Qcf), indicate combined map units consisting of bedrock overlain by thin or discontinuous deposits of the map unit. Map units with (e) such as $\mathrm{Qfb}(\mathrm{e})$ indicate zones of groundwater emergence in the mapped unit. Map units with a question mark such as $\mathrm{Qca}$ ? indicate an uncertain identification.

NOTE: Not all map units appear on each sheet

\section{UNCONSOLIDATED DEPOSITS}

Estimated contents of sand and silt, based on field observations, are indicated by the terms "trace" and "some." "Trace" implies a general composition of 4 to 12 percent. "Some" implies a general composition of 12 to 30 percent. Estimated compositions $<4$ percent are not recorded in the field. Terms used to describe the estimated percentages of cobbles and boulders are "numerous", "scattered", and "rare." "Numerous" implies that drilling through the deposit would encounter two cobbles or boulders in an interval of $0.6 \mathrm{~m}$; "scattered" implies that drilling would encounter two cobbles or boulders in an interval of 3 to $4.5 \mathrm{~m}$; "rare" implies that drilling would encounter two cobbles or boulders in an interval of $>4.5 \mathrm{~m}$.

\section{Alluvial Deposits}

Qa UNDIFFERENTIATED FLOODPLAIN ALLUVIUM-Chiefly well-sorted and well-stratified polymictic pebble gravel, sand, and silt comprising channel (bedload) and overbank (cover) deposits of generally small streams; unfrozen to discontinuously frozen with low to moderate ice content

Qaa ACTIVE-FLOODPLAIN ALLUVIUM-Chiefly well-sorted and well-stratified layers and lenses of polymictic pebble gravel, sand, and silt with rare to scattered cobbles comprising river bars and floodplain cover deposits subject to recurrent inundation by streams every 5 years or less (Chapin and others, 2006); mapped extent is a function of river level (stage) and reflects the transitory extent of exposed river bars and channel locations at the time the photographs were taken; in braided and anastomosing reaches, active channels typically shift positions from year to year and present channel locations may differ from locations in the photographs on which the deposits were mapped; active alluvium underlies banks and active stream channels and includes point-bar and meander-scroll deposits (Brakenridge, 1988); composed dominantly of gravel and sand where stream is braided and anastomosing, and sand and silt bars and cover deposits where meandering; prone to liquefaction where fine grained and unfrozen (Harp and others, 2003); where braided, subject to formation of extensive thick, seasonal-stream icings (aufeis); generally unfrozen, except seasonally frozen to depth of frost penetration; shallow water table

Qai INACTIVE-FLOODPLAIN ALLUVIUM-Chiefly 0.6 to $6 \mathrm{~m}$ of overbank (cover) silty sand and sandy silt overlying gravelly, polymictic riverbed sand and sandy gravel beneath surfaces subject to flooding as often as two to ten times per century (Mason and Begét, 1991; Yarie and others, 1998; Chapin and others, 2006); may include more than one surface at different levels; overbank sequences may include flood-related features such as natural levees, crevasse-splays, and expansion fans near channels, and finegrained back-levee swale deposits farther from channels (Brakenridge, 1988; Mann and others, 1995); scroll lakes have linear, arcuate, and coalesced outlines (Weber and Péwé, 1961, 1970; Péwé, 1970; Reger and Hubbard, 2010); surface peat generally absent; prone to liquefaction where fine grained and unfrozen (Harp and others, 2003); generally unfrozen in younger areas and discontinuously frozen in 
older areas, with low to moderate ice content; active channels may be underlain by 1.5 to $6 \mathrm{~m}$ of generally unfrozen sand and silty sand; fills of inactive channels may include 2.1 to $3.6 \mathrm{~m}$ of discontinuously frozen organic sand and silt with moderate to high ice content over sand and gravelly sand

Qab. ABANDONED-FLOODPLAIN ALLUVIUM-Chiefly 3 to $6 \mathrm{~m}$ of overbank (cover) sandy silt and silty sand overlying sandy, polymictic riverbed gravel beneath surfaces with widespread cover of lowland loess and local sand dunes, and subject to stream flooding about once every 500-1,000 years (Mann and others, 1995); may include several surfaces at different levels; overbank sequences include flood-related features such as natural levees, crevasse splays, and expansion fans near channels, and fine-grained, peaty back-levee swale deposits farther from channels (Brakenridge, 1988; Mann and others, 1995); may contain organic-silt channel fills 2.1 to 6 m thick; surface peat generally discontinuous to widespread in backwater areas away from channels; floodplain lakes are larger than lakes on younger floodplain surfaces and typically have rounded to scalloped shorelines formed by thermokarst erosion; generally frozen with low to moderate ice content

Qaf ALLUVIAL-FAN DEPOSITS-Fan-shaped deposits of unsorted to well-sorted gravel, sand, and silt with numerous cobbles and boulders in proximal zone; in general, size of clasts decreases and degree of sorting increases downfan; clast lithologies reflect bedrock composition in source areas; typically mixed with debris-flow deposits in proximal part of fans; unfrozen to discontinuously frozen, except in finegrained distal deposits where permafrost may be continuous

Qat STREAM-TERRACE ALLUVIUM-Chiefly 1.2 to $>6 \mathrm{~m}$ of organic sandy silt and silty sand overlying well-sorted, polymictic sand and gravel beneath stream terrace treads no longer subject to inundations by the stream that deposited the alluvium (Kreig and Reger, 1982); may include several levels and flood-related features such as natural levees, crevasse-splays, and expansion fans near channels; locally covered by $\leq 4.5 \mathrm{~m}$ of lowland loess and eolian-sand blanket and dune complexes, especially close to active sediment sources; thaw lakes with rounded to scalloped shorelines formed by thermokarst erosion are typically present (Weber and Péwé, 1961, 1970; Péwé, 1970; Reger and Hubbard, 2010); locally subject to seasonal stream icings where buildup of aufeis in stream channels diverts subsequent drainage and spreads aufeis and meltwater across terrace treads that would not otherwise be flooded (Springer and others, 1976; Sloan and others, 1976); continuously to discontinuously frozen with low to moderate ice content

Qfb: UNDIFFERENTIATED FLOOD DEPOSITS - Tanana River on terraces along the southern margin of the Yukon-Tanana Upland; typically downstream from bedrock ridges that trend transverse to the Tanana

Qfbo River; include streamlined terrace remnants preserved downstream from bedrock ridges and knobs and are typically composed of clean, coarse to medium, pebbly sand overlying cobble gravel with scattered large

Qfby granitic flood boulders; impounded clearwater lakes along the northern margin of the Tanana Lowland; include jökulhlaup deposits of the well-drained, low-gradient, broad Tok expansion fan and high-level

Qfs. Delta (Qfbo) and Donnelly (Qfby) flood deposits east of Berry Creek, which are composed of clast- and matrix-supported, tabular, massive to crudely bedded gravel layers interbedded with minor layers of crudely bedded pebbly sand; layers average $\sim 1 \mathrm{~m}$ thick, generally parallel the fan surface, and contain rare extraordinarily large flood boulders; unfrozen to discontinuously frozen; low ice content; Qfs deposits are chiefly organic sandy and silty backswamp sediments deposited during floods in slackwater basins separated from source streams by expansion fans and natural-levee and crevasse-splay complexes; typically inundated by shallow water between flood events; surface vegetation comprises water-tolerant shrubs and peat bogs; may be associated with open-system pingos, numerous thaw ponds and lakes, and thermokarst pits; inferred to be continuously frozen and ice rich

Qft TERRACE DEPOSITS OF TOK RIVER ALLUVIAL FAN—Surface above inactive and abandoned floodplains of Tok River displays former meandering and anastomosing drainage channels of Tok River; composed of micaceous cover silt with trace clay up to $12.7 \mathrm{~cm}$ thick overlying poorly sorted, generally massive to cross-bedded, matrix-supported, pebbly, medium-to-coarse sand with trace silt and rare polymictic cobbles up to $10.2 \mathrm{~cm}$ diameter; moderate imbrication; depth to carbonate-bottomed pebbles varies 
up to $0.8 \mathrm{~m}$; carbonate cements granules and coarse sand to bottom of pebbles; silt caps discontinuous and $<0.25 \mathrm{~cm}$ thick; matrix color dark yellowish brown (10YR4/6) to grayish brown (2.5Y5/2); locally poorly drained; discontinuously frozen with low to moderate ice content

\section{Colluvial Deposits}

Qc UNDIFFERENTIATED COLLUVIUM — Blankets, aprons, cones, and fans of heterogeneously mixed angular to subangular rock fragments, gravel, sand, and silt formed by complex, gravity-driven mass move-

$80 \mathrm{c}$

Qca

Qcd

Qcf

(Qcf)

Qcft

Qcl

Qcg ROCK-GLACIER DEPOSITS-Tongue-shaped heterogeneous surface blanket of angular to subanguments involving sliding, flowing, solifluction (or gelifluction where frozen), and frost creep of weathered bedrock; cobbles and boulders are scattered to numerous; morphologies of colluvial sheets generally reflect underlying surfaces; discontinuously to continuously frozen with low to moderate ice content

SNOW-AVALANCHE DEPOSIT-Steep fans of heterogeneous, rubbly debris with some gravel, sand, and silt deposited by snow avalanches in and downslope of couloirs in steep alpine terrain; surface covered with scattered, angular rock fragments; may be crudely sorted by grain size with the largest fragments farther downslope; typically associated with talus cones and aprons; discontinuously frozen with low to moderate ice content

DEBRIS-FLOW DEPOSIT - Chiefly tongues of angular rock fragments and coarse gravel with a sandy matrix deposited on steep colluvial slopes and fans and in rock-walled upper stream valleys by flowing slurries of mud, sand, rock debris, and gravel generated during sudden, intense summer rainstorms; initial fine fractions are later winnowed, leaving coarse gravel and rubble tongues and lobes, some with natural levees of cobbles and boulders up to $2.1 \mathrm{~m}$ high bounding medial channels with rectangular to U-shaped cross profiles measuring 3 to $21.3 \mathrm{~m}$ across and 3 to $18.3 \mathrm{~m}$ deep; many large boulders and blocks have small debris mounds and scattered cobbles on upper surfaces; generally unfrozen to discontinuously frozen with low ice content

MIXED COLLUVIUM AND ALLUVIUM-Primarily fan-shaped or elongate, massive to poorly stratified, generally inorganic silt mixed with sandy angular to subangular pebble gravels derived from weathered bedrock uplands; colluvial processes are dominant compared to fluvial processes; surface slightly irregular; contains angular to subangular, fresh to weathered rock fragments and grus in weathered granitic bedrock terrain; discontinuously to continuously frozen with low to moderate ice content TECTONICALLY DEFORMED COLLUVIAL-FLUVIAL DEPOSITS-Arcuate ridges of poorly stratified, coarse, sandy grus fragments with trace silt, numerous pebbles, and scattered subrounded to rounded granitic boulders up to $2.7 \mathrm{~m}$ diameter initially deposited as piedmont aprons southwest of Tanacross Airfield by debris flows derived from the steep mountain valleys to the southwest and later tectonically deformed (Carver and others, 2010); sandy granule matrix, color dark brown (7.5YR4/4) to light olive brown (2.5Y5/4); surface smoothly rounded with slopes between $\sim 4$ degrees and $\sim 17$ degrees; partially exhumed granitic boulders stand up to $-1.5 \mathrm{~m}$ in relief; heights of surface boulders greater where surface slopes are steeper; surface stepped by $\sim 20$ degrees to $\sim 25$ degrees scarps of shallow, local slope failures; discontinuously frozen with low ice content lar blocks of local bedrock overlying deformed ice with trace to some gravel, sand, and silt at depth; where active, blocky surface layer is disrupted on steep marginal slopes and core debris is exposed; accumulated on floors and lower walls of cirques and glaciated valleys by flow of rock glaciers derived from shrinking of former glaciers (ice cored) or from deposition, cementation, and deformation of precipitation-derived ground ice (ice cemented); surface typically has furrows, nested arcuate ridges arranged convexly downvalley, and pits, and may have prominent lateral ridges; perennially frozen where active, with moderate to high ice content

LANDSLIDE DEPOSITS-Lunate to triangular or fan-shaped, heterogeneous mixtures of large, fractured bedrock blocks and pebble gravel with scattered to numerous cobbles and boulders and trace to 
some sand and silt deposited by near-surface to deep creeping, flowing, and sliding of failed bedrock and unconsolidated surficial deposits; surface features include gaping ground cracks where active, scarps facing upslope and downslope, slight irregularities, hummocks, low longitudinal ridges, and terminal bulges; unfrozen to continuously frozen with low to moderate ice content

Qcr ROCK-FALL DEPOSITS—Rubble blanket or apron of large, angular rock fragments of local bedrock formed by collapse of upslope outcrop; unfrozen to discontinuously frozen with low ice content

Qct TALUS-Cone- and apron-shaped heterogeneous mixtures of frost-rived, angular rock fragments downslope of bedrock outcrops with trace to some gravel, sand, and silt deposited on steep bedrock slopes and at the mouths of steep bedrock couloirs with U-shaped cross profiles by snow avalanches, free fall, tumbling, rolling, and sliding; surface steep, slightly irregular, and covered with numerous rock fragments, particularly in distal zones; includes debris-flow tongues; blocks and boulders covered by crustose lichens where stable and lichen-free where freshly deposited or displaced; unfrozen to discontinuously frozen with low ice content

\section{Eolian Deposits}

Qe $\therefore$ UNDIFFERENTIATED EOLIAN DEPOSITS—Chiefly well-sorted, massive to finely bedded, primarily airfall eolian sand and loess forming a blanket over bedrock ridges and hills and lowlands in the southern Yukon-Tanana Upland; complex stratigraphy may include retransported sand and silt; discontinuously to continuously frozen with low to high ice content

Qel LOESS - Silt with up to 15 percent very fine sand carried by winds and deposited as a blanket over downwind topography (Péwé, 1951, 1955); mixed with eolian sand on lower slopes and on lowland surfaces close to floodplain sources; may include intimate mixtures with retransported silt; thickness ranges from $>6 \mathrm{~m}$ close to active sediment sources to $\sim 0.6 \mathrm{~m}$ elsewhere (Lindholm and others, 1959); typically rilled where $>0.9 \mathrm{~m}$ thick on steep upper slopes, but areas of mapped loess should be considered minimums because rills are locally obscured by dense vegetation cover; organic rich on lower slopes and lowland sites; moderate to high moisture content (>15 percent) in lowland sites (Kreig and Reger, 1982); generally unfrozen on upper south-facing slopes and sporadically to discontinuously frozen with moderate to high ice content on other lower slopes and in riverine lowlands; generally continuously frozen and ice rich on north-facing slopes and in lowland sites in the Yukon-Tanana Upland

Qer RETRANSPORTED SILT AND SAND COMPLEXLY MIXED WITH LOWLAND LOESSChiefly massive to well-stratified organic silt and sandy silt with lenses and tongues of locally derived gravel and scattered to numerous angular rock fragments (particularly in upper valleys of small, ephemeral streams) and organic fine sand in sand dune areas; deposited primarily by hyperconcentrated flows (Costa, 1988) draining weathered bedrock slopes covered by upland silt (loess) and eolian sand and generated by thawing of ice-rich permafrost or brief, intense summer rainstorms; complexly mixed with debris-flow deposits in upper stream drainages, primary airfall loess and eolian fine sand in lowland sites, and fine-grained distal overbank sediments in slackwater flood basins; fluvial processes are dominant compared to colluvial processes; surface fairly smooth with scattered, open-system pingos and local thermokarst pits, ponds, and lakes; may be subject to seasonal stream and slope icings; discontinuously to continuously frozen; where frozen, moisture content 21-345 percent, averaging 107 percent $(\mathrm{n}=6)$

Qes EOLIAN SAND-Chiefly blankets and dunes of fine to medium, massive to cross-bedded eolian sand with trace to some silt (Kreig and Reger, 1982, pl. 9); dunes stand 1.5 to $4.5 \mathrm{~m}$ in relief and ridges may extend for up to $4.8 \mathrm{~km}$ in the direction of dominant summer winds; mapped extents, based on the presence of dunes, should be considered minimum; discontinuous with thicknesses up to $-7.6 \mathrm{~m}$; unweathered color grayish brown (2.5Y5/2); generally covered by 0.3 to $0.9 \mathrm{~m}$ of loess (Lindholm and others, 1959); locally deposited along the margins of active braided floodplains; average moisture content of unfrozen sand -8 percent (Kreig and Reger, 1982); discontinuously frozen; frozen, moisture content $17-42$ percent, averaging 26 percent $(n=6)$ 


\section{Glacial Deposits}

Qgdh TILL AND ASSOCIATED MORAINAL DEPOSITS OF HOLOCENE GLACIATION-Heterogeneous, nonstratified, polymictic pebble-cobble gravel with some sand and silt and numerous angular to subrounded boulders deposited by glacial ice and associated colluvial processes in upper mountain valleys during Holocene time; boulders of younger deposits are unvegetated or bear crustose lichens; older moraines are typically covered with tundra; loess cover thin and patchy to nonexistent; ice cores may be present, especially in younger moraines; unfrozen to discontinuously frozen with low to moderate ice content

Qgdy TILL AND ASSOCIATED MORAINAL DEPOSITS OF DONNELLY GLACIATION_Heterogeneous, nonstratified, polymictic pebble-cobble gravel with some sand and silt and few to numerous subangular to subrounded boulders deposited by glacial ice and locally reworked by meltwater washing and associated mass-movement processes; may locally include esker and kame deposits; morainal relief 15.2 to $53.3 \mathrm{~m}$; kettle frequency $-6.4 / \mathrm{km} 2$; kettle fillings of silt, peat, and silty colluvium generally thin but may be several meters thick close to active sources of eolian deposits; maximum till thickness -91 $\mathrm{m}$; surface weathering profiles 0.5 to $0.8 \mathrm{~m}$ thick; friable; sand matrix weathered to brown (10YR $5 / 3)$; 25 to 35 percent of schist clasts are intact in weathering profiles and granitic clasts are fresh to slightly weathered; silt caps on clasts generally $<1 \mathrm{~mm}$ thick; discontinuous cover of loess generally $\leq 0.9 \mathrm{~m}$ thick and weathered yellowish brown (10YR5/8) to light yellowish brown (10YR6/4) but eolian sand and silt mantle may be $>6 \mathrm{~m}$ thick close to active sediment sources and may obscure primary surface morphology; ventifacts exhibit slight to moderate surface polish and shallow pitting but lack facets and keels in lags developed beneath loess covers; ice-wedge casts generally rare and up to $0.9 \mathrm{~m}$ wide; unfrozen to discontinuously frozen with low to moderate ice content (Péwé and Holmes, 1964; Holmes, 1965; Carter and Galloway, 1978; Péwé and Reger, 1983, table 3)

Qgdo TILL AND ASSOCIATED MORAINAL DEPOSITS OF DELTA GLACIATIONS—Heterogeneous, nonstratified, polymictic pebble-cobble gravel with some sand and silt and few to numerous subangular to subrounded boulders deposited by glacial ice and massive, sandy pebble gravel with rare cobbles deposited by glacial meltwater and associated mass-movement processes; may include esker and kame complexes; morainal relief 7.6 to $68.6 \mathrm{~m}$; kettle frequency $-1.2 / \mathrm{km} 2$; kettle fillings of silt, peat, and silty colluvium may be several meters thick; maximum till thickness $-60 \mathrm{~m}$; surface weathering profiles generally $0.9-2.1 \mathrm{~m}$ deep, on high-level surfaces may locally be $>3 \mathrm{~m}$ deep; friable to strongly cemented with numerous clast molds; sand matrix weathered light yellowish brown (10YR6/4) to brownish yellow (10YR6/6); 1 to 10 percent of schist clasts are intact in weathered profiles and $\leq 50$ percent of granitic clasts are partially decomposed; clast silt caps range from $<1$ to $3 \mathrm{~mm}$ thick; discontinuously mantled by thin eolian sand and loess; loess cover weathered to light reddish brown (5YR6/4) (rubification); well-formed faceted and keeled ventifacts common in surface lags beneath loess covers; ice-wedge casts scattered to numerous and up to $-1.5 \mathrm{~m}$ wide; wedge fillings include deformed eolian sand that is locally pebbly; unfrozen to discontinuously frozen with low to moderate ice content (Péwé and Holmes, 1964; Holmes, 1965; Carter and Galloway, 1978; Péwé and Reger, 1983, table 3)

QTgdp UNDIFFERENTIATED GLACIAL DRIFT OF PRE-DELTA GLACIATIONS—Thin, discontinuous to continuous sheets of heterogeneous pebble gravel, sand, and silt with rare to numerous cobbles, boulders, and blocks up to $2.4 \mathrm{~m}$ in diameter deposited directly from melting glacial ice and reworked by meltwater streams; includes drift of Darling Creek age and probably other pre-Delta glaciations on alpine surfaces and lower mountain slopes south of the Tanana River; sandy matrix weathered pale brown (10YR6/3) to brown (10YR5/3); surface morphology extensively modified by mass-movement processes; unfrozen to discontinuously frozen with low to moderate ice content (Péwé and Reger, 1983; Weber, 1986; Duk-Rodkin and others, 2004) 


\section{GLACIOFLUVIAL DEPOSITS}

Qgfh OUTWASH OF HOLOCENE GLACIATION-Massive to well-sorted, polymictic pebble-cobble gravel with some sand and numerous subrounded to angular boulders deposited by meltwater streams from Holocene glaciers in upper mountain valleys; locally includes deposits of debris flows and rockfalls; clasts are generally slightly weathered; surfaces unvegetated to vegetated with thin tundra; loess cover nonexistent to thin and patchy; unfrozen to discontinuously frozen with low ice content

Qgfyy OUTWASH OF LATE DONNELLY GLACIATION-Coarse outwash gravel in steep-walled, flatfloored, broad channel incised into surface of outwash fan of Robertson River glacier north of Jan Lake; connects with kame-esker deposits in the Donnelly terminal moraine to the west

Qgfy. OUTWASH OF DONNELLY GLACIATION-Massive to well-sorted, polymictic pebble gravel with some sand and scattered to numerous subrounded to subangular cobbles and boulders $\leq 2.1 \mathrm{~m}$ in diameter in proximal zones; surface weathering profiles $\leq 0.9 \mathrm{~m}$ deep; sand matrix color varies from pale brown (10YR6/3) to brown (10YR5/3); 5 to 10 percent of foliated tillstones are typically split into plates by frost action and granitic tillstones are fresh to slightly weathered in weathered profiles, except locally, where foliated tillstones are shattered to small, platy fragments and granitic clasts are reduced to crumbly remnants by the growth of calcite (caliche) in the upper 0.9 to $1.2 \mathrm{~m}$ of the outwash deposit; clast silt caps thin and discontinuous; cover sands discontinuous and up to $-3 \mathrm{~m}$ thick; average loess cover $\sim 0.1$ $\mathrm{m}$ thick and generally weathered light yellowish brown (10YR6/4) to brown (10YR5/3), except red (2.5YR5/6) where strongly oxidized after repeated wildfires (Ping and others, 2006); ventifacts exhibit slight to moderate surface polish and pitting but no facets or keels in lags developed beneath loess covers; ice-wedge casts generally rare, but locally common and $\leq 0.9 \mathrm{~m}$ wide (Péwé and Reger, 1983, p. 62-66); deformed wedge fillings composed of brown to greenish gray silt with trace to some pebble gravel and scattered cobbles; unfrozen to discontinuously frozen with low ice content

Qfgey ESKER-KAME COMPLEX OF DONNELLY GLACIATION_Complex mixtures of sand, pebble gravel with some sand and silt, and diamicton deposited in holes, tunnels, and narrow ice-walled valleys in stagnant glacial ice by sediment-charged meltwater streams and by debris flows generated by melting glacial ice; subangular to rounded cobbles and boulders range from rare to numerous; well to poorly sorted; thin to massive bedded; locally cross-bedded; surface has high relief (up to $-15 \mathrm{~m}$ ) and is characterized by discontinuous, sinuous, anastomosing and bifurcating, steep-sided ridges (eskers) typically associated with small, steep-sided hills (kames); unfrozen

Qgfo OUTWASH OF DELTA GLACIATION_Massive to well-sorted, polymictic pebble gravel with some sand and numerous subrounded to subangular cobbles and boulders $\leq 1.1 \mathrm{~m}$ in diameter; coarser in proximal zones and finer where distal; surface weathering profiles $\geq 3.6 \mathrm{~m}$ deep; sand matrix color varies from pale brown (10YR6/3) to very pale brown (10YR7/4); -50 percent of foliated and granitic clasts in weathered profile are rotten; silt caps on clasts in weathered profile $\leq 2 \mathrm{~mm}$ thick; cover sands discontinuous and up to $-3 \mathrm{~m}$ thick; loess cover typically 0.3 to $0.6 \mathrm{~m}$ thick; well-formed faceted and keeled ventifacts common in surface lags beneath loess covers; quartz pebbles in lags stained yellowish brown (10YR5/4) to very pale brown (10YR7/4); ice-wedge casts scattered to numerous and $\leq 1.1 \mathrm{~m}$ wide; deformed wedge fillings are typically eolian sand with trace to some silt and pebble gravel and may include scattered pebble ventifacts; unfrozen to discontinuously frozen with low ice content

Qgfeo ESKER-KAME COMPLEX OF DELTA GLACIATION_Complex mixtures of sand, pebble gravel with some sand and silt, and diamicton deposited in holes, tunnels, and narrow, ice-walled valleys in stagnant glacial ice by sediment-charged meltwater streams and by debris flows generated by melting glacial ice; well modified with subdued relief compared to esker-kame complexes of Donnelly age but distinctive sinuous, bifurcated morphology clearly recognizable; unfrozen 


\section{Manmade Deposits}

Qhf ARTIFICIAL FILL—Mixed coarse and fine material emplaced by human activity during land development; includes the infrastructure for the Northway Airport, Tanacross Airport, Tok Airport, and Allen Army Airfield and missile defense complex northwest of Tok, which are built on fill material; artificially compacted; sporadically to discontinuously frozen with generally low ice content; paved surfaces at the Northway Airport were broken by liquefaction during November 2002 earthquake

\section{Lacustrine Deposits}

Qlb LAKE-BOTTOM DEPOSITS—Chiefly silt and clay with some sand and organic material deposited in ephemeral lakes in backwater areas of inactive floodplains and behind ice-shoved ramparts in large lakes; discontinuously to continuously frozen with moderate to high ice content

Qld DELTA DEPOSITS-Chiefly sand and silt with some organic material deposited in lake basins by streams entering the lakes; during floods of the Tanana, Chisana, and Nabesna rivers, streams that normally drain the lakes into the river reverse direction and carry floodwaters and sediments into the lake basins; sporadically frozen with moderate to high ice content

Qlir DEPOSITS OF ICE-SHOVED RIDGES—Single or multiple 0.9- to 1.5-m-high ridges parallel to and 0.6 to $4.5 \mathrm{~m}$ above modern lake shorelines; composed of overturned and severely and complexly deformed deposits of adjacent lake bottoms, including fine to coarse clastic lake-bottom sediments and peat with thin, interlayered light gray lacustrine sands; built by shoreward transport of lake-bottom sediments by wind-driven, drifting lake ice or by expansion of the ice cover on lakes (Dionne, 1979; Sasaki and Nagasawa, 1995); unfrozen to discontinuously frozen with low to moderate ice content

\section{Paludal Deposits}

Qp SWAMP DEPOSITS - Primarily fibrous and locally woody, autochthonous peat with organic silt and sand deposited in lowland sites (Kreig and Reger, 1982); $\leq 2.4$ m thick; discontinuously to continuously frozen with moderate to high ice content

\section{Residual Deposits}

QTr BLOCK RUBBLE-Nests and blankets of angular to subangular blocks derived by frost wedging and jacking of underlying bedrock (autochthonous block fields) on high-level surfaces (felsenmeer of Carrara, 2004a and b) or as lags left by winnowing of sandy matrix from gelifluction deposits or thin till by subterranean piping (allochthonous block fields); locally may be included in units of thinly covered bedrock (b') and as nests of large blocks plucked from granitic bedrock by massive floods in shallow strath terraces in the vicinity of Sears Creek; sizes of blocks are a function of joint spacing in local bedrock; associated microrelief features formed by frost action and mass movement include stone polygons, stone nets and circles, stone stripes, nonsorted circles and hummocks, and soil lobes and benches; frost jacking locally active; discontinuously frozen with low to moderate ice content

\section{BEDROCK}

b UNDIFFERENTIATED BEDROCK-Outcrops of igneous, metamorphic, and sedimentary rocks; linear and curvilinear shallow troughs and linear boundaries in surface vegetation indicate the presence of planar bedrock structures

b' THINLY COVERED BEDROCK—Subcrops with $<0.9 \mathrm{~m}$ of loess and colluvium; bedrock structures recognizable through thin veneers of surficial debris

b+b' BEDROCK AND THINLY COVERED BEDROCK-Complex map unit consisting of bedrock outcrops and thinly-buried subcrops that cannot be mapped separately 


\section{MAP SYMBOLS}

NOTE: Map symbols below might not all appear on this sheet

- _ _ PHOTOINTERPRETED CONTACT_Identity and existence certain; location approximate

$\leftrightharpoons$ STRIKE-SLIP FAULT, LEFT-LATERAL OFFSET-Identity or existence certain, location accurate; arrows show relative motion

二- STRIKE-SLIP FAULT, LEFT-LATERAL OFFSET—Identity or existence certain, location approximate; arrows show relative motion

$\longrightarrow$ THRUST FAULT - Identity and existence certain, location accurate. Sawteeth on upper (tectonically higher) plate

- $\boldsymbol{-}$ THRUST FAULT —Identity and existence certain, location approximate. Sawteeth on upper (tectonically higher) plate

- $\boldsymbol{~ ? ~ T H R U S T ~ F A U L T ~ — I d e n t i f y ~ a n d ~ e x i s t e n c e ~ q u e s t i o n a b l e , ~ l o c a t i o n ~ a p p r o x i m a t e ~ S a w t e e t h ~ o n ~ u p p e r ~ ( t e c - ~}$ tonically higher) plate

$\cdots \boldsymbol{*} \cdot \cdots$ THRUST FAULT - Identity and existence certain, location concealed. Sawteeth on upper (tectonically higher) plate

$\cdots \checkmark \cdots$ ? THRUST FAULT - Identity and existence questionable, location concealed. Sawteeth on upper (tectonically higher) plate

--- - . LINEAMENT

$\underline{1}$ ANTICLINE-Identity and existence certain, location accurate.

$--\mathfrak{\Downarrow}-\quad$ ANTICLINE-Identity and existence certain, location inferred.

$\cdots \uparrow . . . \quad$ ANTICLINE_Identity and existence certain, location concealed.

……? ANTICLINE—Identity or existence questionable, location concealed.

$\diamond \quad$ FOSSIL LOCALITY

- RADIOCARBON LOCALITY

$\triangle \quad$ SOIL PIT LOCALITY

$\checkmark \quad$ VENTIFACT LOCALITY

- TRENCH LOCALITY

$\star \quad$ Tephra locality discussed in REPORT (SCHAEFER, 2002)

$\times \quad$ MAP LOCALITY DISCUSSED IN TEXT

\section{REFERENCES}

Brakenridge, G.R., 1988, River flood regime and floodplain stratigraphy, in Baker, V.R., Kochel, R.C., and Patton, P.C., eds., Flood geomorphology: New York, John Wiley \& Sons, p. 139-156.

Carrara, P.E., 2004a, Surficial geologic map of the Tanacross B-6 Quadrangle, east-central Alaska: U.S. Geological Survey Scientific Investigations Map 2850, version 1.0, 9 p., 1 plate, scale 1:63,360.

2004b, Surficial geologic map of the Tanacross B-5 Quadrangle, east-central Alaska: U.S. Geological Survey Scientific Investigations Map 2856, version 1.0, 9 p., 1 plate, scale 1:63,360.

Carter, L.D., and Galloway, J.P., 1978, Preliminary engineering geologic maps of the proposed natural gas pipeline route in the Tanana River valley, Alaska: U.S. Geological Survey Open File Report 78794, 26 p., 3 sheets, scale $1: 125,000$.

Carver, G.A., Bemis, S.P., Solie, D.N., Castonguay, S.R., and Obermiller, K.E., 2010, Active and potentially active faults in or near the Alaska Highway corridor, Dot Lake to Tetlin Junction, Alaska: Alaska Division of Geological \& Geophysical Surveys Preliminary Interpretive Report 2010-1, 42 p. http://doi.org/10.14509/21121 
Chapin, F.S., III, Viereck, L.A., Adams, P.C., Van Cleve, Keith, Fastie, C.L., Ott, R.A., Mann, Daniel, and Johnston, J.F., 2006, Successional processes in the Alaskan boreal forest, in Chapin, F.S., III, Oswood, M.W., Van Cleve, Keith, Viereck, L.A., and Verbyla, D.L., eds., Alaska's changing boreal forest: Oxford, England, Oxford University Press, p. 100-120.

Costa, J.E., 1988, Rheologic, geomorphic, and sedimentologic differentiation of water floods, hyperconcentrated flows, and debris flows, in Baker, V.R., Kockel, R.C., and Patton, P.C., eds., Flood geomorphology: New York, John Wiley \& Sons, p. 113-122.

Dionne, J.C., 1979, Ice action in the lacustrine environment-A review with particular reference to subarctic Quebec, Canada: Earth-Science Reviews, v. 15, no. 3, p. 185-212.

Duk-Rodkin, Alejandra, Barendregt, R.W., Froese, D.G., Weber, F.R., Enkin, Randy, Smith, I.R., Zazula, G.D., Waters, Pamela, and Klassen, Rudy, 2004, Timing and extent of Plio-Pleistocene glaciations in northwestern Canada and east-central Alaska, in Ehlers, J., and Gibbard, P.L., eds., Quaternary glaciations-Extent and chronology, Part II-North America: Developments in Quaternary Sciences, v. 2, part B, p. 313-345. http://doi.org/10.1016/ S1571-0866(04)80206-9

Harp, E.L., Jibson, R.W., Kayen, R.E., Keefer, D.K., Sherrod, B.L., Carver, G.A., Collins, B.D., Moss, R.E.S., and Sitar, Nicolas, 2003, Landslides and liquefaction triggered by the M 7.9 Denali fault earthquake of 3 November 2002: GSA Today, v. 13, no. 8, p. 4-10.

Holmes, G.W., 1965, Geologic reconnaissance along the Alaska Highway, Delta River to Tok Junction, Alaska: U.S. Geological Survey Bulletin, 1181-H, 19 p., 1 sheet, scale 1:125,000.

Kreig, R.A., and Reger, R.D., 1982, Air-photo analysis and summary of landform soil properties along the route of the Trans-Alaska Pipeline System: Alaska Division of Geological \& Geophysical Surveys Geologic Report 66, 149 p. http://doi.org/10.14509/426

Lindholm, G.F., Thomas, L.A., Davidson, D.T., Hardy, R.L., and Roy, C.J., 1959, Silts near Big Delta and Fairbanks, in Davidson, D.T., and Roy, C.J., eds., The geology and engineering characteristics of some Alaskan silts: Iowa Engineering Experiment Station Bulletin 186, p. 33-70.

Mann, D.H., Fastie, C.L., Rowland, E.L., and Bigelow, N.H., 1995, Spruce succession, disturbance, and geomorphology on the Tanana River floodplain, Alaska: Ecoscience, v. 2, no. 2, p. 184-199.

Mason, O.K., and Begét, J.E., 1991, Late-Holocene flood history of the Tanana River, Alaska, USA: Arctic and Alpine Research, v. 23, no. 4, p. 392-403.

Péwé, T.L., 1951, An observation of wind-blown silt: Journal of Geology, v. 59, no. 4, p. 399-401.

1955, Origin of the upland silt near Fairbanks, Alaska: Geological Society of America Bulletin, v. 66, p. 699-724.

-1970, Permafrost and vegetation in floodplains of subarctic rivers (Alaska), a summary, in Ecology of the subarctic regions-Proceedings of the Helsinki symposium: UNESCO, p. 141-142.

Péwé, T.L., and Holmes, G.W., 1964, Geology of the Mt. Hayes D-4 Quadrangle, Alaska: U.S. Geological Survey Miscellaneous Geologic Investigations Map I-394, 2 sheets, scale 1:63,360.

Péwé, T.L., and Reger, R.D., 1983, Delta River area, Alaska Range, in Péwé, T.L., and Reger, R.D., eds., Guidebook to permafrost and Quaternary geology along the Richardson and Glenn highways between Fairbanks and Anchorage, Alaska: Alaska Division of Geological \& Geophysical Surveys Guidebook 1, p. 47-135. http://doi. org/10.14509/263

Ping, C.L., Boone, R.D., Clark, M.H., Packee, E.C., and Swanson, D.K., 2006, State factor control of soil formation in interior Alaska, in Chapin, F.S., III, Oswood, M.W., Van Cleve, Keith, Viereck, L.A., and Verbyla, D.L., eds., Alaska's changing boreal forest: New York, Oxford University Press, p. 21-38.

Reger, R.D., and Hubbard, T.D., 2010, Reconnaissance interpretation of 1978-1983 permafrost, Alaska Highway corridor, Robertson River to Tetlin Junction, Alaska: Alaska Division of Geological \& Geophysical Surveys Preliminary Interpretive Report 2009-6c, 13 p., 4 sheets, scale 1:63,360. http://doi.org/10.14509/19743

Sasaki, Tatsumi, and Nagasawa, Tohru, 1995, Shoreward movement of grounded lake ice and sediment transport-An application of a two-dimensional elastic model: Arctic and Alpine Research, v. 27, no. 3, p. 283-289.

Schaefer, J.R.G., 2002, Stratigraphy, major oxide geochemistry, and 40Ar/39Ar geochronology of a tephra section near Tok, Alaska: Fairbanks, University of Alaska Fairbanks M.S. thesis, 62 p.

Sloan, C.E., Zenone, Chester, and Mayo, L.R., 1976, Icings along the trans-Alaska pipeline route: U.S. Geological Survey Professional Paper 979, 31 p. 
Springer, W.J., George, T.H., and Bell, R.M., 1976, Identification of flood hazard resulting from aufeis formation in an interior Alaskan stream: Unpublished University of Alaska Geophysical Institute report for U.S. Department of Agriculture Soil Conservation Service, 12 p.

Weber, F.R., 1986, Glacial geology of the Yukon-Tanana Upland, in Hamilton, T.D., Reed, K.M., and Thorson, R.M., eds., Glaciation in Alaska—The geologic record: Anchorage, Alaska Geological Society, p. 79-98.

Weber, F.R., and Péwé, T.L., 1961, Engineering geology problems in the Yukon-Koyukuk lowland, Alaska, in Short Papers in the Geologic and Hydrologic Sciences 1961: U.S. Geological Survey Professional Paper 424D, p. 371-373.

1970, Surficial and engineering geology of the central part of the Yukon-Koyukuk lowland, Alaska: U.S. Geological Survey Miscellaneous Geologic Investigations Map I590, 2 sheets, scale 1:125,000.

Yarie, John, Viereck, Leslie, Van Cleve, Keith, and Adams, Phyllis, 1998, Flooding and ecosystem dynamics along the Tanana River: BioScience, v. 48, no. 9, p. 690-695. 


\section{Appendix B: Permafrost DESCRIPTION OF INTERPRETIVE PERMAFROST MAP UNITS INTRODUCTION}

Permafrost, or perennially frozen ground, is rock or soil that remains continuously colder than $0^{\circ} \mathrm{C}$ for 2 years or longer (Muller, 1947; Ferrians and others, 1969; Péwé, 1966, 1982). On the basis of the interpretation of $\sim$ 1:65,000-scale false-color infrared aerial photographs, this map illustrates the inferred extent and estimated ice content of permafrost between the ground surface and a depth of $6 \mathrm{~m}$ in the proposed corridor straddling the Alaska Highway between Delta Junction and the Canada border from July 1978 to July 1983, the dates of the aerial photographs. The presence or former presence of permafrost and the ground-ice content are inferred from several indicators, including vegetation, slope and aspect, landform, soil type, local drainage, and terrain features, such as open-system pingos, polygonal ground, and thermokarst pits, gullies, and ponds (Kreig and Reger,1982). After initial permafrost maps were completed, airborne-resistivity data collected in 2005 and 2006 became available in a series of sengpiel resistivity sections with a maximum depth of $100 \mathrm{~m}$ (Burns and others, 2006). We were able to compare our initial interpretations with those data, producing considerable map changes, especially in the extensive riverine lowlands where subsurface circulation of ground water is pervasive and evidence indicates that permafrost is thinning and becoming less continuous. Because of the paucity of confirming subsurface data in the proposed corridor, we consider our interpretation to be tentative until validated by multi-year ground-temperature measurements that verify the presence of frozen ground. Permafrost classifications in areas that were burned just prior to August 1980 are less reliable than in unburned areas because the surface vegetation was destroyed or significantly altered and, in those areas interpretation of permafrost is based primarily on landform and setting, which are less diagnostic than vegetation. The user is cautioned that this map has not been verified by field observations, except very locally, although we have considerable field experience in the Tanana River valley and during our interpretation referred to available published and unpublished maps. Physical properties of map units are extrapolated from similar deposits in the region and from previously published reports and data. Detailed subsurface investigations should be completed prior to development in the corridor.

\section{NOTE: Not all map units appear on each sheet}

\section{PERMAFROST MAP UNITS}

Symbols indicate the inferred continuity of permafrost in uppercase letters and the estimated ice content in lowercase letters. For example, "Dm" indicates that discontinuous permafrost with low to moderate ice content is inferred between the ground surface and a depth of $-6 \mathrm{~m}$. Classes of permafrost continuity are consistent with classes used in previous mapping in Alaska (Ferrians, 1965; Kreig and Reger, 1982; Brown and others, 1997; Jorgenson and others, 2008).

CONTINUOUSLY FROZEN-More than 90 PERCENT of the area is inferred to be underlain by permafrost; can include local areas of polygonal ground. Ground temperature at level of no seasonal variation is $-5^{\circ} \mathrm{C}$ to $-11^{\circ} \mathrm{C}$

DISCONTINUOUSLY FROZEN-Between 50 and 90 percent of the area is inferred to be underlain by permafrost; can include local areas of polygonal ground and scattered thaw lakes; ground temperature at level of no seasonal variation is $-1^{\circ} \mathrm{C}$ to $-5^{\circ} \mathrm{C}$ can include local areas of polygonal ground and concentrations of thaw lakes; ground temperature at level of no seasonal variation is $0^{\circ} \mathrm{C}$ to $+1^{\circ} \mathrm{C}$ to be underlain by permafrost; ground temperature at depth of no seasonal variation is $0^{\circ} \mathrm{C}$ to $+1^{\circ} \mathrm{C}$ 
MODERATE TO HIGH ICE CONTENT_Estimated to typically contain 50 to >1,000 percent gravimetric soil moisture relative to dry weight

$\mathrm{m}$

LOW TO MODERATE ICE CONTENT_Estimated to typically contain 25 to 50 percent gravimetric soil moisture relative to dry weight

I LOW ICE CONTENT_Estimated to typically contain 5 to 25 percent gravimetric soil moisture relative to dry weight

\section{EXPLANATION OF MAP UNITS}

Fr CONTINUOUSLY FROZEN, MODERATE TO HIGH ICE CONTENT

Fm CONTINUOUSLY FROZEN, LOW TO MODERATE ICE CONTENT

Dr DISCONTINUOUSLY FROZEN, MODERATE TO HIGH ICE CONTENT

Dm DISCONTINUOUSLY FROZEN, LOW TO MODERATE ICE CONTENT

DI DISCONTINUOUSLY FROZEN, LOW ICE CONTENT

Sr SPORADICALLY FROZEN, MODERATE TO HIGH ICE CONTENT

Sm SPORADICALLY FROZEN, LOW TO MODERATE ICE CONTENT

SI SPORADICALLY FROZEN, LOW ICE CONTENT

G GENERALLY UNFROZEN (ISOLATED PERMAFROST MASSES)

U NO KNOWN PERMAFROST

WATER, ASSUMED UNDERLAIN BY TALIKS

\section{MAP SYMBOLS}

NOTE: Map symbols below might not all appear on this sheet

\section{----- PHOTOINTERPRETED BOUNDARY-ALL BOUNDARIES ARE INFERRED OR} APPROXIMATELY LOCATED

- SOIL MOISTURE LOCALITIES (TABLE 4, THIS REPORT)

- TEMPERATURE LOCALITY-A temperature of $-2.1^{\circ} \mathrm{C}$ was recorded at the level of zero amplitute (7.6 m deep) on 3/15/2009

汸 INTACT OR BREACHED OPEN-SYSTEM PINGO

$\star \quad$ LITHALSA

$\diamond \quad$ FOSSIL LOCALITY

$\checkmark$ PERMAFROST EXPERIMENTAL SITE 


\section{REFERENCES}

Brown, J., Ferrians, O.J., Jr., Heginbottom, J.A., and Melnikov, E.S., 1997, Circum-arctic map of permafrost and ground-ice conditions: U.S. Geological Survey Circum-Pacific Map CP-45, 1 sheet, scale 1:10,000,000.

Burns, L.E., Fugro Airborne Surveys Corp., and Stevens Exploration Management Corp., 2006, Line, grid, and vector data and plot files for the airborne geophysical survey of the Alaska Highway corridor, east-central Alaska: Alaska Division of Geological \& Geophysical Surveys Geophysical Report 2006-6, 1 DVD. http://doi. org/10.14509/14864

Ferrians, O.J., Jr., 1965, Permafrost map of Alaska: U.S. Geological Survey Miscellaneous Geologic Investigations Map I-445, 1 sheet, scale 1:2,500,000.

Ferrians, O.J., Jr., Kachadoorian, Reuben, and Green, G.W., 1969, Permafrost and related engineering problems in Alaska: U.S. Geological Survey Professional Paper 678, 37 p.

Jorgenson, Torre, Yoshikawa, Kenji, Kanevskiy, Mikhail, Shur, Yuri, Romanovsky, Vladimir, Marchenko, Sergei, Grosse, Guido, Brown, Jerry, and Jones, Ben, 2008, Permafrost characteristics of Alaska, in Kane, D.L., and Hinkel, K.M., eds., Proceedings of the Ninth International Conference on Permafrost, Fairbanks, Alaska: University of Alaska Fairbanks, p. 121-122.

Kreig, R.A., and Reger, R.D., 1982, Air-photo analysis and summary of landform soil properties along the route of the Trans-Alaska Pipeline System: Alaska Division of Geological \& Geophysical Surveys Geologic Report 66, 149 p. http://doi.org/10.14509/426

Muller, S.W., 1947, Permafrost or permanently frozen ground and related engineering problems: Ann Arbor, Michigan, J.W. Edwards, Inc., 231 p.

Péwé, T.L., 1966, Permafrost and its effect on life in the North: Corvallis, Oregon State University Press, 40 p. 1982, Geologic hazards of the Fairbanks area, Alaska: Alaska Division of Geological \& Geophysical Surveys Special Report 15, 109 p. http://doi.org/10.14509/2614 


\section{Appendix C: Engineering Geology}

\section{DESCRIPTION OF ENGINEERING-GEOLOGIC MAP UNITS INTRODUCTION}

This map is derived electronically from the surficial-geologic map of the Alaska Highway corridor (this report) using Geographic Information System (GIS) software. Surficial-geologic units were initially identified by interpretation of - 1:65,000-scale false-color infrared aerial photographs taken between July 1978 and August 1981 and locally verified by field checking in 2006-2010. The map shows the distribution of surficial-geologic and bedrock units grouped genetically with common properties that are typically significant for engineering applications. For surficial-geologic units, common geologic processes typically produce similar deposits (Kreig and Reger, 1982).

$\begin{array}{ll}\text { A } & \text { ALLUVIAL DEPOSITS } \\ \text { C } & \text { COLLUVIAL DEPOSITS } \\ \text { E } & \text { EOLIAN DEPOSITS } \\ \text { F } & \text { FLOOD DEPOSITS } \\ \text { G } & \text { GLACIAL DEPOSITS }\end{array}$

H MANMADE DEPOSITS

L LAKE DEPOSITS

P PALUDAL PEAT DEPOSITS

B BEDROCK AND RESIDUAL

The accompanying table lists generalized properties of these groups, including surface drainage, susceptibility to frost action, the presence of perennially frozen ground, and the consequences of thawing, stability of slopes, suitabilities and limitations of material for construction purposes, and potential constraints. Physical properties of map units are interpretive, based on extrapolation from verified localities and from previously published reports and data. Potential geologic hazards are inferred from the typical physical properties of map units, including sediment texture and ground-ice content, and their typical topographic settings. Except for a few test pits, granulometric analyses, and determination of gravimetric soil moisture, no subsurface investigations were performed for this publication. The reader is cautioned that this map is intended only as a general guide, and that unevaluated geologic resources and hazards may be present. Detailed geotechnical investigations should be conducted prior to utilization of any map units for engineering purposes.

\section{MAP SYMBOLS}

NOTE: Map symbols below might not all appear on this sheet

PHOTOINTERPRETED BOUNDARY_All boundaries are inferred or approximately located WATER

\section{REFERENCES}

Chapin, F.S., III, Viereck, L.A., Adams, P.C., Van Cleve, Keith, Fastie, C.L., Ott, R.A., Mann, Daniel, and Johnston, J.F., 2006, Successional processes in the Alaska boreal forest, in Chapin, F.S., III, Oswood, M.W., Van Cleve, Keith, Viereck, L.A., and Verbyla, D.L., eds., Alaska’s changing boreal forest: Oxford, England, Oxford University Press, p. 100-120.

Kreig, R.A., and Reger, R.D., 1982, Air-photo anlaysis and summary of landform soil properties along the route of the Trans-Alaska Pipeline System: Alaska Division of Geological \& Geophysical Surveys Geologic Report 66, 149 p. http://doi.org/10.14509/426

Mann, D.H., Fastie, C.L., Rowland, E.L., and Bigelow, N.H., 1995, Spruce succession, disturbance, and geomorphology on the Tanana River floodplain, Alaska: Ecoscience, v. 2, no. 2, p. 184-199.

Mason, O.K., and Begét, J.E., 1991, Late Holocene flood history of the Tanana River, Alaska, U.S.A.: Arctic and Alpine Research, v. 23, no. 4, p. 392-403.

Yarie, John, Viereck, Leslie, Van Cleve, Keith, and Adams, Phyllis, 1998, Flooding and ecosystem dynamics along the Tanana River: BioScience, v. 48, no. 9, p. 690-695. 
Table of engineering-geologic properties

\begin{tabular}{|c|c|c|c|c|c|c|c|c|}
\hline $\begin{array}{l}\text { Map } \\
\text { Label }\end{array}$ & & Geologic units & Surface drainage & $\begin{array}{l}\text { Susceptibility } \\
\text { to frost action }\end{array}$ & Permafrost and thaw stability & Slope stability & Suitability for construction & Potential engineering considerations \\
\hline A1 & $\begin{array}{l}\text { Qa } \\
\text { Qaa }\end{array}$ & $\begin{array}{l}\text { Alluvium } \\
\text { Active-floodplain Alluvium }\end{array}$ & $\begin{array}{l}\text { Well-drained near steep } \\
\text { stream banks and where } \\
\text { water table is deep; } \\
\text { seasonally flooded }\end{array}$ & $\begin{array}{l}\text { Subject to deep dry } \\
\text { freezing where coarse- } \\
\text { grained and water table } \\
\text { is deep; subject to intense } \\
\text { frost action where silty }\end{array}$ & $\begin{array}{l}\text { Unfrozen to discontinuously frozen with } \\
\text { low to moderate ice content where sitty; } \\
\text { can be thaw unstable where perennially } \\
\text { frozen and silty }\end{array}$ & $\begin{array}{l}\text { Highly susceptible to lateral } \\
\text { erosion and collapse near active } \\
\text { channels }\end{array}$ & $\begin{array}{l}\text { Excellent source of clean, sandy gravel } \\
\text { aggregate and clean fill material; can be poorly } \\
\text { graded; well-drained sand and gravel provide } \\
\text { excellent foundation }\end{array}$ & $\begin{array}{l}\text { Subject to inundation every } 1-5 \text { years during high } \\
\text { stream stages and by auffeis in braided reaches; } \\
\text { shallow water table limits depth of excavation; thawed } \\
\text { fine sand and silt subject to liquefaction; responses to } \\
\text { seismic shaking can vary considerably, especially near } \\
\text { frozen zones }\end{array}$ \\
\hline A2 & Qai & Inactive-floodplain Alluvium & $\begin{array}{l}\text { Generally poor due to } \\
\text { shallow water table and } \\
\text { shallow permafrost; } \\
\text { moderate to good on } \\
\text { natural levees and crevasse } \\
\text { splays }\end{array}$ & $\begin{array}{l}\text { Generally subject to } \\
\text { intense frost action in } \\
\text { fine-grained cover } \\
\text { deposits and channel fills; } \\
\text { not susceptible where } \\
\text { coarse grained }\end{array}$ & $\begin{array}{l}\text { Unfrozen in younger areas to } \\
\text { discontinuous in older areas, generally } \\
\text { with tow to moderate ice content, high } \\
\text { ice content in frozen organic sand and } \\
\text { silt channel fills; thaw unstable where } \\
\text { frozen and ice rich }\end{array}$ & $\begin{array}{l}\text { Highly susceptible to lateral } \\
\text { erosion and collapse near active } \\
\text { channels; subject to differential } \\
\text { settlement when thawed }\end{array}$ & $\begin{array}{l}\text { Where thawed, excellent source of sandy gravel } \\
\text { aggregate beneath silty surface layer; presence } \\
\text { of permatrost and shallow water can limit } \\
\text { potential as source of sandy graval aggregate } \\
\text { and suitability for foundation }\end{array}$ & $\begin{array}{l}\text { Subject to inundation at least once or twice every } \\
100 \text { years (Chapin and others, } 2006 ; \text { Yarie and } \\
\text { others, } 1998) ; \text { shallow water table limits depth of } \\
\text { excavation; where thawed, fine sand and silt subject } \\
\text { to liquefaction; responses to seismic shaking can vary } \\
\text { considerably }\end{array}$ \\
\hline A3 & Qab & Abandoned-flooplain Alluvium & $\begin{array}{l}\text { Generally poor due to } \\
\text { widespread, shallow } \\
\text { permafrost }\end{array}$ & \begin{tabular}{|l|} 
Generally subject to \\
intense frost action in \\
fine-grained cover \\
deposits and channel fills; \\
not susceptible where \\
coarse grained
\end{tabular} & $\begin{array}{l}\text { Generally frozen with low to moderate } \\
\text { ice content; high ice content in frozen } \\
\text { surface peats and organic sand and } \\
\text { suitt channel fills; thaw unstable where } \\
\text { frozen and ice rich }\end{array}$ & $\begin{array}{l}\text { Susceptible to lateral erosion } \\
\text { and collapsen near active } \\
\text { channels; subject to differential } \\
\text { settlement when thawed }\end{array}$ & $\begin{array}{l}\text { Widespread permafrost and shallow water } \\
\text { table can limit potential as source of sandy } \\
\text { gravel aggregate and suitability for foundation }\end{array}$ & 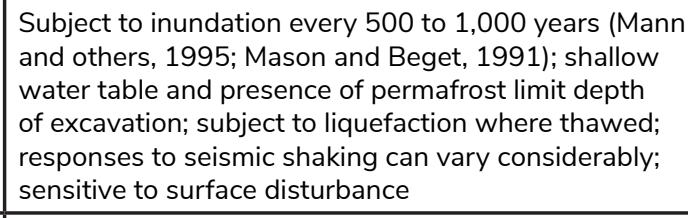 \\
\hline A4 & $\begin{array}{l}\text { Qat } \\
\text { Qft }\end{array}$ & Terrace Alluvium & $\begin{array}{l}\text { Good near descending } \\
\text { scarps; fair to poor away } \\
\text { from scarps; subject to } \\
\text { local flooding; subject to } \\
\text { groundwater emergence }\end{array}$ & $\begin{array}{l}\text { Intense in fine-grained } \\
\text { cover sediments } \\
\text { and silty channel fills; } \\
\text { not susceptible where } \\
\text { coarse grained }\end{array}$ & $\begin{array}{l}\text { Continuously to discontinuously frozen } \\
\text { with low to moderate ice content; high } \\
\text { ice content in frozen surface peat, thaw } \\
\text { unstable where frozen and ice rich }\end{array}$ & $\begin{array}{l}\text { Susceptible to lateral erosion } \\
\text { and collapse near active } \\
\text { channels; frozen zones subject } \\
\text { to differential settlement when } \\
\text { thawed }\end{array}$ & $\begin{array}{l}\text { Excellent source of sand and gravel beneath } \\
\text { fine- grained cover sediments, although shallow } \\
\text { permarost can limit depth of excavation } \\
\text { bedrock may be shallow in strath terraces; } \\
\text { excellent foundation where thatwed; subject to } \\
\text { groundwater emergence }\end{array}$ & $\begin{array}{l}\text { Bedrock shallow in strath terraces; locally subject to } \\
\text { seasonal slope and stream flooding; where saturated, } \\
\text { and where groundwater emerging fine-grained cover } \\
\text { sediments subject to liquefaction; seismic shaking can } \\
\text { vary considerably especially near frozen zones; locally } \\
\text { sensitive to surface disturbance }\end{array}$ \\
\hline A5 & Qaf & Alluvial-fan Deposits & $\begin{array}{l}\text { Generally good, except in } \\
\text { frozen distal zones }\end{array}$ & $\begin{array}{l}\text { Intense in fine-grained } \\
\text { cover deposits and } \\
\text { silty zones, otherwise not } \\
\text { frost susceptible }\end{array}$ & $\begin{array}{l}\text { Unfrozen to discontinuously frozen, } \\
\text { except in fine grained distal zones } \\
\text { where permafrost is presents ice } \\
\text { content low to moderate; thaw unstable } \\
\text { where fine grained }\end{array}$ & $\begin{array}{l}\text { Subject to lateral erosion and } \\
\text { collapse near active channels }\end{array}$ & $\begin{array}{l}\text { Engineering qualities variable but can be good, } \\
\text { depending on rock quality upstream; generally } \\
\text { unsuitable as aggregate source in proximal and } \\
\text { distal areas due to numerous boulders, high sitt } \\
\text { content, and permafrost; moderate suitability for } \\
\text { foundations }\end{array}$ & $\begin{array}{l}\text { Proximal zones subject to torrential flooding, } \\
\text { snow avalanches, debris flows, and mudflows; subject } \\
\text { to sudden shifts in channels and sites of deposition } \\
\text { and erosion }\end{array}$ \\
\hline A6 & $\begin{array}{l}\text { Qer } \\
\text { Qfs }\end{array}$ & $\begin{array}{l}\text { Restransported Eolian Silt and Sand } \\
\text { Slackwater Flood Deposits }\end{array}$ & $\begin{array}{l}\text { Generally poor; can be } \\
\text { seasonally flooded }\end{array}$ & Intense & $\begin{array}{l}\text { Permafrost is discontinuous to } \\
\text { continous with moderate to high ice } \\
\text { content; thaw unstable }\end{array}$ & $\begin{array}{l}\text { Highly susceptible to gullying } \\
\text { and piping when vegetation is } \\
\text { removed; subject to differential } \\
\text { settlement when thawed }\end{array}$ & $\begin{array}{l}\text { Source of organic material for landscaping; } \\
\text { generally unsuitable as an aggregate source; } \\
\text { can be suitable for foundations when } \\
\text { permafrost is preserved }\end{array}$ & $\begin{array}{l}\text { Thawing produces mudflows and hyperconcentrated } \\
\text { flows; subject to seasonal stream and slope icings; } \\
\text { sensitive to surface disturbance }\end{array}$ \\
\hline $\mathrm{F}$ & $\begin{array}{l}\text { Qfb } \\
\text { Qffo } \\
\text { Qfby }\end{array}$ & Jökulhlaup Deposits & $\begin{array}{l}\text { Generally excellent to good, } \\
\text { except moderate to poor } \\
\text { in areas of groundwater } \\
\text { emergence or where } \\
\text { shallowly frozen }\end{array}$ & $\begin{array}{l}\text { Intense in fine-grained } \\
\text { cover sediments; } \\
\text { otherwise, not susceptible }\end{array}$ & $\begin{array}{l}\text { Unfrozen to discontinuously frozen with } \\
\text { low to moderate ice content; generally } \\
\text { thaw stable, except unstable where } \\
\text { silty }\end{array}$ & $\begin{array}{l}\text { Subject to lateral erosion and } \\
\text { collapse near active channels }\end{array}$ & $\begin{array}{l}\text { Good source of sand and gravel; large flood } \\
\text { boulders locally abundant; excellent foundation } \\
\text { material }\end{array}$ & $\begin{array}{l}\text { Bedrock shallow in strath terraces; areas of } \\
\text { groundwater emergence can be subject to seasonal } \\
\text { surface icings and saturated soil conditions }\end{array}$ \\
\hline C1 & $\begin{array}{l}\text { Qc } \\
\text { Qca } \\
\text { Qcd } \\
\text { Qcf } \\
\text { Qcft } \\
\text { Qcg } \\
\text { Qcr } \\
\text { Qct } \\
\text { QTr }\end{array}$ & $\begin{array}{l}\text { Colluvium } \\
\text { Snow-avalanche Deposits } \\
\text { Debris-flow Deposits } \\
\text { Collluvium and Alluvium } \\
\text { Tectonically Deformed Qcf } \\
\text { Rock-glacier Deposits } \\
\text { Rock-fall Deposits } \\
\text { Talus } \\
\text { Block Rubble }\end{array}$ & Generally good & $\begin{array}{l}\text { Fine-grained cover } \\
\text { sediments susceptible }\end{array}$ & $\begin{array}{l}\text { Unfrozen to discontinuously } \\
\text { frozen with low to moderate ice } \\
\text { content; generally thaw stable, } \\
\text { except where silty }\end{array}$ & $\begin{array}{l}\text { Generally stable unless toe or } \\
\text { margin of slope is removed; } \\
\text { locally subject to sloughing } \\
\text { and sliding; subject to snow } \\
\text { avalanching and rock falls }\end{array}$ & $\begin{array}{l}\text { Generallly unsuitable as aggregate source } \\
\text { because numerous large, angular fragments } \\
\text { require special handling; rubble sheets can be } \\
\text { suitable as a aggregrate and rip-rap source } \\
\text { locally; where frozen, can require riping or } \\
\text { blasting; poor foundation where blocks are } \\
\text { loose and unstable to good foundation where } \\
\text { coarse and fine fractions are mixed and stable }\end{array}$ & Could become unstable if margins or toe removed \\
\hline C2 & Qcl & Landslide Deposits & Generally good & $\begin{array}{l}\text { Fine-grained cover } \\
\text { sediments susceptible }\end{array}$ & $\begin{array}{l}\text { Unfrozen to discontinuously } \\
\text { frozen with low to moderate ice } \\
\text { content; generally thaw unstable where } \\
\text { fine grained }\end{array}$ & $\begin{array}{l}\text { Generally unstable; } \\
\text { subject to rapid to slow } \\
\text { downslope movement }\end{array}$ & $\begin{array}{l}\text { Generally unsuitable for foundation and } \\
\text { construction because of slope instability; } \\
\text { suitability as an aggregate source is variable, } \\
\text { depending on bedrock character }\end{array}$ & $\begin{array}{l}\text { Could become unstable if margin or toe is removed; } \\
\text { building on, below or adjacent to landslide deposits is } \\
\text { not recommended }\end{array}$ \\
\hline
\end{tabular}


Table of engineering-geologic properties, continued

\begin{tabular}{|c|c|c|c|c|c|c|c|c|}
\hline $\begin{array}{l}\text { Map } \\
\text { Label }\end{array}$ & & Geologic units & Surface drainage & $\begin{array}{l}\text { Susceptibility } \\
\text { to frost action }\end{array}$ & Permafrost and thaw stability & Slope stability & Suitability for construction & Potential engineering considerations \\
\hline E1 & $\begin{array}{l}\text { Qe } \\
\text { Qel }\end{array}$ & $\begin{array}{l}\text { Eolian Deposits } \\
\text { Loess }\end{array}$ & $\begin{array}{l}\text { Generally good, } \\
\text { except poorly drained } \\
\text { where frozen }\end{array}$ & $\begin{array}{l}\text { Intense where moist to } \\
\text { wet; low where dry }\end{array}$ & $\begin{array}{l}\text { Generally discontinuously to } \\
\text { continuously frozen, except on upper } \\
\text { south-facing slopes; moderate to high } \\
\text { ice content on lower south-facing and } \\
\text { on north-facing slopes; thaw unstable } \\
\text { where ice content is moderate to high }\end{array}$ & $\begin{array}{l}\text { Highly susceptible to } \\
\text { gullying and piping; subject } \\
\text { to differential settlement upon } \\
\text { thawing where frozen and } \\
\text { ice rich }\end{array}$ & $\begin{array}{l}\text { Source of organics and fine fractions for } \\
\text { landscaping and mixing; makes good foundation } \\
\text { where thawed and dry }\end{array}$ & $\begin{array}{l}\text { Vertical cuts can be stable if drainage is provided; } \\
\text { ice-rich areas sensitive to surface disturbance; muddy } \\
\text { when wet; dusty when dry }\end{array}$ \\
\hline E2 & Qes & Eolian Sand & $\begin{array}{l}\text { Generally good, except } \\
\text { poorly drained where } \\
\text { covered with frozen silt }\end{array}$ & $\begin{array}{l}\text { Generally } \\
\text { unsusceptible, except in } \\
\text { siity cover deposits }\end{array}$ & $\begin{array}{l}\text { Generallly unfrozen to frozen, } \\
\text { except silty cover sediments are } \\
\text { discontinuously to continuously frozen } \\
\text { and locally ice rich }\end{array}$ & $\begin{array}{l}\text { Highly susceptible to gullying } \\
\text { and defflation }\end{array}$ & $\begin{array}{l}\text { Possible source of fines for landscaping and } \\
\text { mixing; makes good foundation where thawed } \\
\text { and dry; compaction difficulties affect its utility } \\
\text { as a foundation material }\end{array}$ & $\begin{array}{l}\text { Subject to deflation where unprotected; prone to } \\
\text { liquefaction where saturated and thawed }\end{array}$ \\
\hline G1 & $\begin{array}{l}\text { Qgdh } \\
\text { Qgdy } \\
\text { Qgdo } \\
\text { QTgdp }\end{array}$ & \begin{tabular}{|l} 
Till of Holocene Glaciation \\
Till of Donnelly Glaciation \\
Till of Delta Glaciation \\
Pre-Late Pleistocene Glacial Drift
\end{tabular} & $\begin{array}{l}\text { Generally good on } \\
\text { upland surfaces and poor in } \\
\text { depressions }\end{array}$ & \begin{tabular}{|l} 
Generally low \\
susceptibility where \\
well drained; moderate \\
to intense where matrix \\
is sitty and in sitty \\
slopewash deposits in \\
depressions
\end{tabular} & $\begin{array}{l}\text { Unfrozen to discontinuously frozen with } \\
\text { low to moderate ice content, depending } \\
\text { on silt content of matrix, generally thaw } \\
\text { stable, except can be thaw unstable in } \\
\text { silty tills and silty kettle fillings }\end{array}$ & $\begin{array}{l}\text { Generally stable where frozen } \\
\text { or dry; subject to instability } \\
\text { where fine-grained tills are } \\
\text { thawed and ice content is } \\
\text { moderate to high }\end{array}$ & $\begin{array}{l}\text { Highly variable but can be good local source } \\
\text { of mixed coarse and fine fractions for fill; local } \\
\text { sources of watere-washed sand and gravel; good } \\
\text { foundations where thawed and dry }\end{array}$ & $\begin{array}{l}\text { Subject to gullying where surface runoff is } \\
\text { concentrated }\end{array}$ \\
\hline G2 & $\begin{array}{l}\text { Qgfey } \\
\text { Qgfeo }\end{array}$ & $\begin{array}{l}\text { Esker-kame Deposits of Donnelly Age } \\
\text { Esker-kame Deposits of Delta Age }\end{array}$ & Generally good & $\begin{array}{l}\text { Generally low } \\
\text { susceptibility where } \\
\text { drained }\end{array}$ & $\begin{array}{l}\text { Unfrozen to discontinuously frozen with } \\
\text { low ice content }\end{array}$ & \begin{tabular}{|l|}
$\begin{array}{l}\text { Generally stable, except subject } \\
\text { to raveling where steep gravel } \\
\text { slopes are undercut }\end{array}$ \\
\end{tabular} & $\begin{array}{l}\text { Highly variable but can be good source } \\
\text { of water-washed sand and gravel; good } \\
\text { foundation where thawed and dry }\end{array}$ & Locally rich in oversize material \\
\hline G3 & $\begin{array}{l}\text { Qgfh } \\
\text { Qgfyy } \\
\text { Qgfy } \\
\text { Qgfo }\end{array}$ & $\begin{array}{l}\text { Glacial Outwash of Holocene Age } \\
\text { Glacial Outwash of Late-Donnelly Age } \\
\text { Glacial Outwash of Donnelly Age } \\
\text { Glacial Outwash of Delta Age } \\
\end{array}$ & Good & $\begin{array}{l}\text { Generallly unsusceptible; } \\
\text { can be intense in silty } \\
\text { cover deposits }\end{array}$ & $\begin{array}{l}\text { Unfrozen to discontinuously frozen with } \\
\text { low ice content }\end{array}$ & $\begin{array}{l}\text { Subject to lateral erosion and } \\
\text { collapse near active channels; } \\
\text { cut faces subject to raveling }\end{array}$ & $\begin{array}{l}\text { Excellent source of sand and gravel; excellent } \\
\text { foundation where thawed and well drained }\end{array}$ & $\begin{array}{l}\text { Easily compacted, although locally contains numerous } \\
\text { large boulders }\end{array}$ \\
\hline L1 & $\begin{array}{l}\text { Qlb } \\
\text { Qld }\end{array}$ & $\begin{array}{l}\text { Lake-Bottom Deposits } \\
\text { Delta Deposits }\end{array}$ & $\begin{array}{l}\text { Very poor; subject to } \\
\text { seasonal flooding }\end{array}$ & Intense & $\begin{array}{l}\text { Discontinuous to continuous } \\
\text { permantrost with moderate to high ice } \\
\text { content; thaw unstable }\end{array}$ & $\begin{array}{l}\text { Near active channels subject } \\
\text { to lateral thermo-erosion and } \\
\text { collapse }\end{array}$ & $\begin{array}{l}\text { Generally unsuitable as an aggregrate source; } \\
\text { generally unsuitable for foundations }\end{array}$ & $\begin{array}{l}\text { Subject to seasonal flooding during high stream } \\
\text { stages; muddy during wet weather }\end{array}$ \\
\hline L2 & Qir & Deposits of Ice-Shoved Ridges & $\begin{array}{l}\text { Generally good, } \\
\text { but variable }\end{array}$ & Intense if wet or moist & $\begin{array}{l}\text { Unfrozen to discontinuously frozen } \\
\text { with low to moderate ice content; thaw } \\
\text { unstable where frozen and ice rich }\end{array}$ & $\begin{array}{l}\begin{array}{l}\text { Subject to differential } \\
\text { settlement where frozen and } \\
\text { ice rich }\end{array} \\
\end{array}$ & $\begin{array}{l}\text { Possible low-volume source of sandy gravel } \\
\text { and organic material for landscaping; generally } \\
\text { unsuitable for foundations }\end{array}$ & Subject to ice shoving in winter near lake shores \\
\hline $\mathrm{H}$ & Qhf & Artificial Fill & Generally good & $\begin{array}{l}\text { Only where fine grained; } \\
\text { otherwise not susceptible }\end{array}$ & $\begin{array}{l}\text { Unfrozen to discontinuously frozen with } \\
\text { low to moderate ice content generally } \\
\text { thaw stable, except where silty }\end{array}$ & $\begin{array}{l}\text { Subject to lateral erosion and } \\
\text { collapse near active channels }\end{array}$ & $\begin{array}{l}\text { Fill material used for runways, taxiways, ramps, } \\
\text { roads, building foundations, embankments, and } \\
\text { artficiali levees mav be suitable for construction; } \\
\text { may not be suitable for all uses }\end{array}$ & $\begin{array}{l}\text { Subject to inundation every } 500 \text { to } 1,000 \text { years } \\
\text { (Chapin and others, 2006; Yarie and others, , } 998) \text {; } \\
\text { shallow water table; potentially unstable where } \\
\text { underlying material is thawed and subject to } \\
\text { liquefaction; can become locally unstable if margins } \\
\text { undercut }\end{array}$ \\
\hline $\mathrm{P}$ & Qp & Swamp Deposits & $\begin{array}{l}\text { Generally very poor; subject } \\
\text { to seasonal flooding }\end{array}$ & Intense & $\begin{array}{l}\text { Discontinuous to continuous } \\
\text { permafrost with moderate to very high } \\
\text { ice content; thaw unstable }\end{array}$ & $\begin{array}{l}\text { Subject to lateral erosion and } \\
\text { collapse near active channels; } \\
\text { subject to subsidence when } \\
\text { thawed } \\
\end{array}$ & $\begin{array}{l}\text { Source of organic material for landscaping; } \\
\text { generally unsuitable as an aggregrate source; } \\
\text { generally unsuitable for foundations }\end{array}$ & $\begin{array}{l}\text { Difficult to excavate and compact; subject to seasonal } \\
\text { slope and stream icings; subject to considerable thaw } \\
\text { strain and compaction upon thawing }\end{array}$ \\
\hline B & $\begin{array}{l}b \\
b^{\prime} \\
b+b^{\prime} \\
\text { (Qc) } \\
\text { (Qcf) }\end{array}$ & $\begin{array}{l}\text { Bedrock } \\
\text { Thinly Covered Bedrock }\end{array}$ & $\begin{array}{l}\text { Generally poor, except } \\
\text { where highly broken }\end{array}$ & $\begin{array}{l}\text { Low, except where } \\
\text { rock is highly weathered } \\
\text { or fractured }\end{array}$ & $\begin{array}{l}\text { Generally thaw stable, except where ice } \\
\text { forms in extensive fracture spaces }\end{array}$ & $\begin{array}{l}\text { Generally stable, except where } \\
\text { orientation of joints, fractures, } \\
\text { or foliation facilitate failure }\end{array}$ & $\begin{array}{l}\text { Can be good source for crushed aggregate and } \\
\text { rip rap where rock is hard, fresh, and not highly } \\
\text { fractured; variable suitability as a foundation } \\
\text { material, depending on the character of the } \\
\text { bedrock }\end{array}$ & $\begin{array}{l}\text { Quality of rock varies, depending on lithology, } \\
\text { degree of weathering, and fracturing; local zones of } \\
\text { weathering or shearing can be clay rich }\end{array}$ \\
\hline
\end{tabular}

